\title{
Changes in Flood Response of the Red River of the North Basin, North Dakota-Minnesota
}

\section{United States \\ Geological}

\section{Survey}

Water-Supply

Paper 2243

Prepared in cooperation with the Upper Mississippi River Basin Commission SourisRed-Rainy Regional Committee and the North Dakota State Water Commission

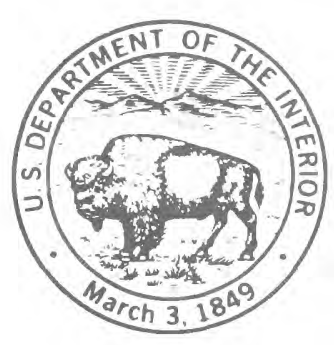




\title{
Changes in Flood Response of the Red River of the North Basin, North Dakota-Minnesota
}

\author{
By JEFFREY E. MILLER and DALE L. FRINK
}

Prepared in cooperation with the Upper Mississippi River Basin Commission SourisRed-Rainy Regional Committee and the North Dakota State Water Commission 


\title{
DEPARTMENT OF THE INTERIOR WILLIAM P. CLARK, Secretary
}

\author{
U.S. GEOLOGICAL SURVEY \\ Dallas L. Peck, Director
}

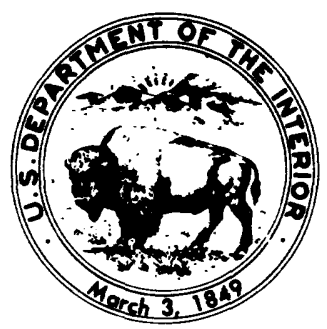

UNITED STATES GOVERNMENT PRINTING OFFICE: 1984

For sale by Distribution Branch

Text Products Section

U.S. Geological Survey

604 South Pickett Street

Alexandria, Virginia 22304

Library of Congress Cataloging in Publication Data

Miller, Jeffrey $E$.

Changes in flood response of the Red River of the North

Basin, North Dakota-Minnesota.

(Water-supply paper ; 2243)

"Prepared in cooperation with the Upper Mississippi River

Basin Commission, Souris-Red-Rainy Regional Committee,

and the North Dakota State Water Commission."

Bibliography: $p$.

Supt. of Docs. no.: I 19.12:2243

1. Floods-Red River of the North Watershed. 2. Floods-

Minnesota. 3. Floods-North Dakota. I. Frink, Dale L.

II. Upper Mississippi River Basin Commission. III.

United States. Souris-Red-Rainy River Basins Commission.

IV. North Dakota State Water Commission. V. Title.

VI. Series: Geological Survey water-supply paper ; 2243.

TC801.U2 no. $2243 \quad 553.7^{\prime} 0973$ s

[GB1399.4.R4] [551.48'9'097641]

83-600253 


\title{
CONTENTS
}

\author{
Abstract 1 \\ Introduction $\mathbf{1}$ \\ Acknowledgments 1 \\ Part 1-Hydrologic setting 2 \\ Hydrology of the Red River of the North basin 2 \\ General characteristics of basin 2 \\ Topography and stream channels 3 \\ Geologic setting 7 \\ Climate 7 \\ Localized excess-water problems 8 \\ Flood characteristics 9 \\ Controlling processes 10 \\ Historical and recorded floods 13 \\ Flood-control works 15 \\ Purported effects of drainage, channel improvements, and other \\ land-use changes 16 \\ Water-routing studies 17 \\ Regression-analysis studies 19 \\ Watershed-model-analysis studies $\mathbf{2 0}$ \\ Miscellaneous studies 21 \\ History of basin changes 22 \\ The analysis problem perspective 24 \\ Hydrologically 24 \\ Historically 25 \\ Regionally 25 \\ Part 2-Data review 25 \\ Streamflow data $\mathbf{2 5}$ \\ Climatological data 25 \\ Part 3-Analysis of flood response $\mathbf{2 5}$ \\ Flood-frequency analysis $\mathbf{2 6}$ \\ Procedure 26 \\ Discussion 26 \\ Normalized-hydrograph analysis $\mathbf{2 6}$ \\ Procedure $\mathbf{3 0}$ \\ Discussion 31 \\ Double-mass analysis 32 \\ Procedure 32 \\ Discussion $\mathbf{3 4}$ \\ Regression analysis 36 \\ Procedure 36 \\ Data development 37 \\ Parameter development $\mathbf{3 7}$ \\ Discussion 40 \\ Summary and conclusions 43
}


Additional studies $\mathbf{4 4}$

Hydrologic and hydraulic data 44

Hydrologic-processes research $\mathbf{4 4}$

Flow-routing tools 45

Historical information 45

Streamflow-gaging methods 45

References cited 45

Conversion factors 48

\section{ATTACHMENTS}

A. Listing of steamflow stations and their corresponding period of record for the Red River of the North basin in North Dakota and Minnesota 49

B. Listing of peak discharges on the Red River of the North at Fargo and Grand Forks 54

C. Hydrographs for the Red River of the North for the snowmelt-runoff periodMarch, April, and May 55

C1. Hydrographs for the Red River of the North at Fargo 55

C2. Hydrographs for the Red River of the North at Grand Forks 72

D. Variation of snowmelt peak discharge by year at Fargo and Grand Forks 89

D1. Variation of snowmelt peak discharge by year at Fargo 89

D2. Variation of snowmelt peak discharge by year at Grand Forks 90

E. Variation in 30-day maximum snowmelt-runoff volume by year at Fargo and Grand Forks 91

E1. Variation in 30-day maximum snowmelt-runoff volume by year at Fargo 91

E2. Variation in 30-day maximum snowmelt-runoff volume by year at Grand Forks 92

F. Variation of antecedent-moisture index by year at Fargo and Grand Forks 93

F1. Variation of antecedent-moisture index by year at Fargo 93

F2. Variation of antecedent-moisture index by year at Grand Forks 94

G. Variation in winter precipitation by year at Fargo and Grand Forks 95

G1. Variation in winter precipitation by year at Fargo 95

G2. Variation in winter precipitation by year at Grand Forks 96

H. Variation of winter temperature by year 97

I. Variation of snowmelt index by year at Fargo and Grand Forks 98

I1. Variation of snowmelt index by year at Fargo 98

I2. Variation of snowmelt index by year at Grand Forks 99

J. Comparison of recorded and modeled snowmelt-runoff peak discharge by year at Fargo and Grand Forks 100

J1. Comparison of recorded and modeled snowmelt-runoff peak discharge by year at Fargo 100

J2. Comparison of recorded and modeled snowmelt-runoff peak discharge by year at Grand Forks 101

$\mathrm{K}$. Comparison of recorded and modeled maximum 30-day snowmelt-runoff volumes by year at Fargo and Grand Forks 102

$\mathrm{K} 1$. Comparison of recorded and modeled maximum 30-day snowmelt-runoff volumes by year at Fargo 102

K2. Comparison of recorded and modeled maximum 30-day snowmelt-runoff volumes by year at Grand Forks 


\section{FIGURES}

1. Map showing location of Red River of the North basin 3

2. Map showing the major subbasins and tributaries, Red River of the North basin 5

3. Graph showing variation to be expected in predicted flood frequency based on forty 25-year periods of record (Benson, 1960, p. 58) 15

4. Map showing existing and planned or authorized flood-control works in the Red River of the North basin 16

5-14. Graphs showing:

5. Annual peak-flow-frequency analysis for the Red River of the North at Fargo, N. Dak., for the two periods of (a) 1882, 1897, and 1901-1949, and (b) 1950-1979 27

6. Annual peak-flow-frequency analysis for the Red River of the North at Grand Forks, N. Dak., for the two periods of 1882-1949 and 1950-1979 28

7. Annual peak-flow-frequency analysis for the Mississippi River at St. Paul, Minn., for the two periods of 1880-1949 and 1950-1979 29

8. Annual peak-flow-frequency analysis for the Red River of the North at Fargo, N. Dak., for the three periods of I902-1929, 1930-1954, and 1955-1979 30

9. Annual peak-flow-frequency analysis for the Red River of the North at Grand Forks, N. Dak., for the four periods of 1882-1904, 1905-1929, 1930-1954, and 1955-1979 31

10. Normalized hydrographs for the Red River of the North at Fargo for the two periods of 1905-1948 and 1950-1980 and at Grand Forks for the periods of 1904-1949 and 1950-1980 33

11. Averaged normalized hydrographs for the Red River of the North at Fargo for the periods of 1905-1948 and 1950-1980 34

12. Averaged normalized hydrographs for the Red River of the North at Grand Forks for the periods of 1904-1949 and 1951-1980 35

13. Results of the double-mass analysis using peak-discharge data from 1904 to $1980 \quad 36$

14. Results of the double-mass analysis using peak-discharge data from 1882 to 198037

15. Map showing locations of climatic stations used in the regression analysis 38

16. Graph showing variation of land-use index by year $\mathbf{4 0}$

17. Pie diagram showing percentage of the total variability in peak discharge accounted for by the individual climatic and other parameters affecting snowmelt flooding on the Red River of the North at Grand Forks 42

\section{TABLES}

1. Listing of river miles for landmarks long the Red River of the North 4

2. Total land area according to land use for the Red River of the North basin in the United States 6

3. Listing of approximate water-surface elevations at flood stage along the Red River of the North 6

4. Significant tributaries of the Red River of the North, listed in order from south to north 6

5. Percentage of total flood volume contributed by the tributary rivers to the Red River of the North at four locations on the main stem-values averaged for the 1948, 1950,1965, 1966, and 1969 floods 
6. Contributions of effective (contributing) drainage area from tributary rivers at key locations on the Red River of the North main stem $\mathbf{1 0}$

7. Hydrologic processes and the factors affecting the processes that control the magnitude of floods in the Red River of the North basin 11

8. Major historical and recorded floods on the Red River of the North main stem 14

9. Acres benefiting from drainage in 196724

10. Years from which snowmelt-runoff hydrographs for the Red River of the North were chosen to be included in the normalized-hydrograph analysis $\mathbf{3 2}$

11. List of climatological stations and the factors used to compute the weighted monthly precipitation over the Red River of the North basin $\mathbf{3 8}$

12. Hydrologic processes affecting flooding and the degree to which each process was accounted for in the regression analysis $\mathbf{4 1}$

13. Regression parameters and recorded and modeled peak discharges for the Red River of the North floods at Grand Forks during the 1800's 


\title{
Changes in Flood Response of the Red River of the North Basin, North Dakota-Minnesota
}

\author{
By Jeffrey E. Miller and Dale L. Frink'
}

\begin{abstract}
The magnitude and frequency of large floods that have occurred in recent years in the basin of the Red River of the North have caused concern that land-use changes and manmade drainage have increased flooding. This study was undertaken to determine whet her any changes in flood response of the basin could be documented. A review of the hydrologic setting, previous floods, flood-control measures, and probable effects of land-use changes shows that the flooding problem of the Red River basin is complex hydrologically, highly variable historically, and follows a regional pattern. Therefore, a change in flood response of the basin is difficult to identify. The floodfrequency, normalized-hydrograph, double-mass, and regression analyses show little indication of significant change in flood response of the Red River basin at locations on the main stem. However, the large variation in flood discharges may mask or dwarf small changes in response.
\end{abstract}

\section{INTRODUCTION}

The Red River valley was settled in the late 1800's. The settlers almost immediately impacted the hydrologic system (Upham, 1895, p. 586). Roads were built across the flat prairie, land was farmed, and bridges were built. A few drainage ditches were installed even before the turn of the century. Since the mid-1900's extensive manmade drainage has been developed. This includes drainage of wetlands and potholes, improved drainage of farm fields, and channel improvements on virtually every tributary of the Red River of the North. Because of the magnitude and number of floods that have occurred in recent years, there has been public concern that manmade drainage has increased flooding in the valley. Therefore, the Upper Mississippi River Basin Commission requested that this

'North Dakota State Water Commission study be undertaken to determine whether any changes in flood response of the basin could be documented.

The objectives of this study are to (1) provide a review of the hydrologic setting of the basin so that currently available data can be identified and the problem can be put in perspective; (2) document, to the extent possible, any significant changes in flood response in recent years; and (3) identify the need for further, possibly more quantitative, studies.

The scope of this study is limited to an analysis of the flood response of the river's main stem. Flooding problems of the tributaries and other localized problems are not addressed in detail in this report.

The main body of this report is divided into three parts. Part 1 is a review of the hydrologic setting of the basin based on currently available data and literature. Part 2 is a review of the available streamflow and climatological data. Part 3 is a description of the investigation of changes in flood response of the Red River basin. To document a change in flood response of a basin, it must be shown that the relationship between the amount of water available to begin runoff in the basin and the resulting runoff characteristics has changed. The runoff characteristics used are the peak-flow rate and the volume of flow recorded at the streamflow-gaging stations at Fargo and Grand Forks. The flood-response analysis includes the results of the flood-frequency, normalized-hydrograph, double-mass, and regression analyses.

\section{ACKNOWLEDGMENTS}

Recognition is due Quentin F. Paulson, U.S. Geological Survey, for his contribution to the geologic setting part of this report and Arvin J. Fisher, U.S. Geological 
Survey, for the development of computer programs that produced the computer plots in this report. Climatological data were furnished by John W. Enz, North Dakota State Climatologist, and by Earl Kuehnast, Minnesota State Climatologist. The literature review for this study was made possible by the contribution of reports from the U.S. Army Corps of Engineers, the North Dakota State Water Commission, the Souris-Red-Rainy Regional Committee of the Upper Mississippi River Basin Commission, the U.S. Soil Conservation Service, and the U.S. Fish and Wildlife Service.

\section{PART 1-HYDROLOGIC SETTING}

The description of the hydrologic setting of the Red River of the North basin is based on a review of currently available reports and data. This review has been accomplished, in part, with reports and other input provided by Federal and State agencies concerned with the flooding problems of the basin. The purpose of this review is to put the analysis of the Red River of the North basin flooding problem in perspective hydrologically, historically, and regionally.

\section{Hydrology of the Red River of the North Basin}

The hydrology of the Red River of the North basin is complex because of the basin's size, shape, subbasin variability, and extreme variation in seasons. Long-term records and historical information indicate that the basin has experienced a large variation in flood flows with time.

\section{General Characteristics of Basin}

The location of the Red River of the North basin (fig. 1) is near the geographical center of North America. The river drains parts of the States of North Dakota, Minnesota, and South Dakota, and parts of the Provinces of Ontario, Manitoba, and Saskatchewan, Canada. It is a tributary of the Nelson River, which flows into Hudson Bay. Fenneman (1931) placed the basin of the Red River of the North in the western lake section, Central Lowland province of the interior plains. The area is characterized as glaciated plain with moraines, lakes, and lacustrine plains.

Upham (1895, p. 582 and 604-606) foresaw that agriculture would be the chief industry and principal land use of the prairie part of the valley due to the fertility of the alluvial, lacustrine, and drift deposits. He attributed the abrupt change in vegetation from prairie in the west to forest in the east to the large increase in annual precipitation across the basin and to the effect of prairie fires almost annually before the area was settled. The prairie fires destroyed seedling trees and shrubs, preventing the advancement of the forest and thereby maintaining the prairie grasses. While parts of the forested area have been cleared for agriculture, the abrupt change is still apparent.

According to Upham $(1895$, p. 52 , with reference to an 1852 report of the Geological Survey of Wisconsin, lowa, and Minnesota), the name Red River was first applied by the Ojibway Indians to the outlet stream of Lower Red Lake, Minn., flowing westward towards Grand Forks, N. Dak., and then northward to Lake Winnipeg. The idea that the Red Lake River formed the headwaters of the Red River is not unreasonable since it is a major tributary to the Red River of the North. The name Red River of the North was given to the river to distinguish it from the Red River in Leuisiana. Henceforth, in the text of this paper the name Red River is used.

The mouth of the Red River is at Lake Winnipeg in Manitoba. Lake Winnipeg is about $250 \mathrm{mi}$ long and drains from its northern end through the Nelson River northeastward to Hudson Bay.

Because of the Red River's sinuosity (large number of meanders), the channel length of the river is nearly double the length of the direct line. The river mileage at the United States-Canadian boundary is $155 \mathrm{mi}$ (table 1). From the boundary, the river extends southward $394 \mathrm{mi}$ to Wahpeton, N. Dak., and Breckenridge, Minn.

The Ottertail and Bois de Sioux Rivers combine at Wahpeton-Breckenridge to form the Red River (fig. 2). The headwater of the Ottertail River is a small lake near the southwest corner of Clearwater County, Minn., about $13 \mathrm{mi}$ west of Lake Itasca, at an elevation of about $1,550 \mathrm{ft}$ above NGVD of 1929. From this point the river flows southward $60 \mathrm{mi}$ (measured in a direct line) through a succession of small lakes to Ottertail Lake (elevation about $1,315 \mathrm{ft}$ ) and then westward 42 mi to Breckenridge, Minn. The Bois de Sioux River forms the MinnesotaNorth Dakota and the Minnesota-South Dakota State lines from Wahpeton south to Lake Traverse, a distance of about $28 \mathrm{mi}$. From Lake Traverse the Bois de Sioux flows northward to its junction with the Ottertail River.

The Red River at the international boundary drains a total area of $40,070 \mathrm{mi}^{2}$. Of this area, $2,000 \mathrm{mi}^{2}$ is in the upper Pembina River basin in Canada. Also, about $1,130 \mathrm{mi}^{2}$ of the total area in northwestern Minnesota is drained by the Roseau River, which joins the Red River north of the international boundary. The total area within the United States that is drained by the Red River is $39.200 \mathrm{mi}^{2}$. Of this area. $570 \mathrm{mi}^{2}$ is in South Dakota: $20,820 \mathrm{mi}^{2}$ is in North Dakota; and $17,810 \mathrm{mi}^{2}$ is in Minnesota (Souris-Red-Rainy River Basin Commission, 1972b, p. D-37).

A listing according to land use for the area of the United States drained by the Red River is given in table 2 .

\section{Flood Response, Red River, N.Dak-Minn.}



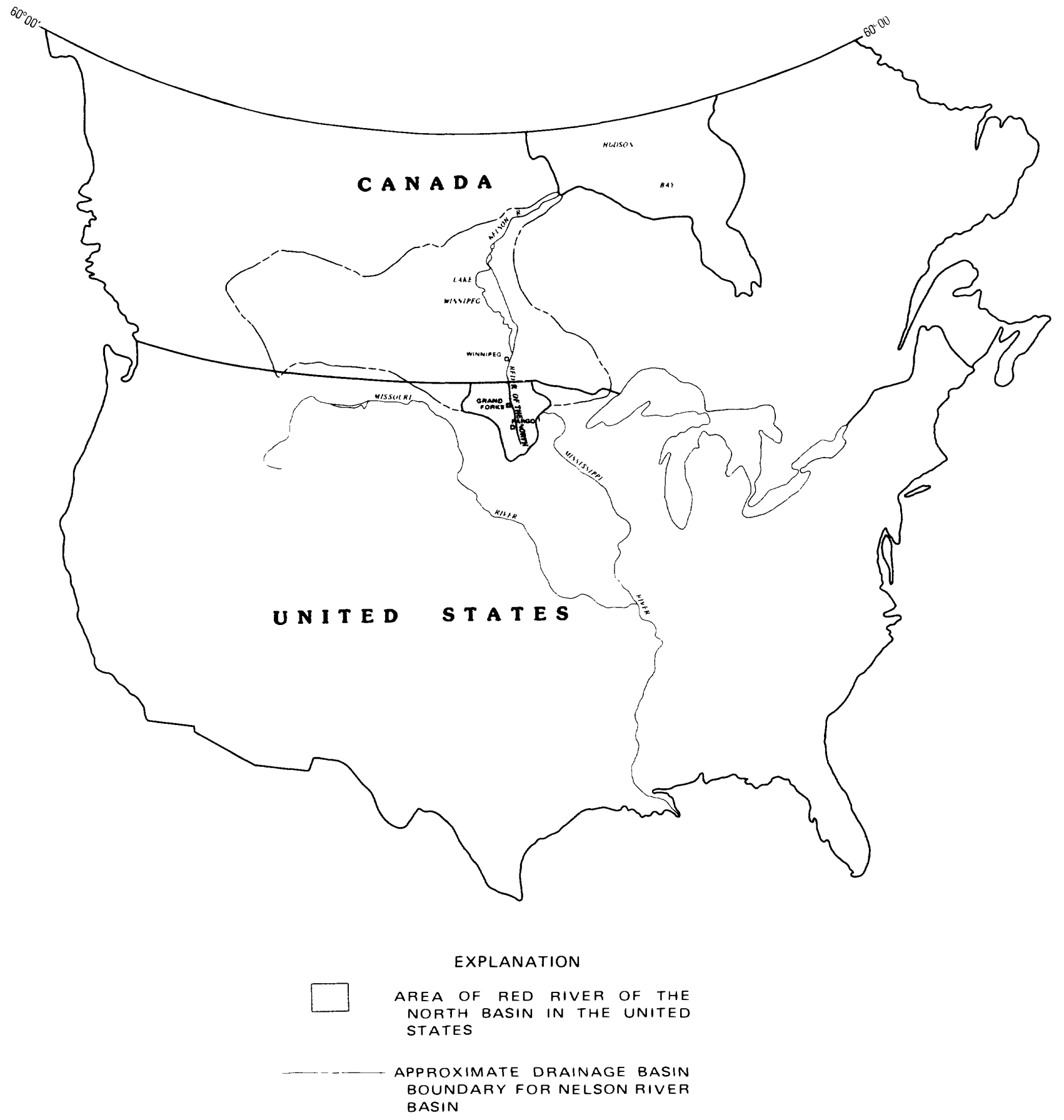

Figure 1. Location of Red River of the North basin.

This information was compiled in 1967 and reported by the Souris-Red-Rainy River Basin Commission (1972a, p. 19).

Because it is difficult to ascertain when certain depressional-storage areas in the basin drain, determining an actual contributing drainage area can be complicated. Therefore, the drainage area values given here include a significant amount of noncontributing or partly contributing areas. One large noncontributing area is the closed Devils Lake basin, which covers $3,580 \mathrm{mi}^{2}$.

\section{Topography and stream channels}

The Red River basin contains two distinct types of 
Table 1. Listing of river miles for landmarks along the Red River of the North

[North Dakota State Water Commission and Minnesota Department of Natural Resources Division of Waters, Soils, and Minerals, 1971, p. 18-19]

Name of landmark

Mileage

International boundary

Minnesota Highway 17 l North Dakota Highway 59 bridge, Pembina, $M$. Oak., and St. Vincent, Minn.

Two Rivers, Minn.

Minnesota Highway 175-North Dakota Highway 5 bridge

Minnesota Highway 11-North Dakota Highway 66 bridge, Drayton, N. Dak.

U.S. Geological Survey streamflow-gaging station at Drayton, N. Dak.

Tamarac River, Minn.

Park River, N. Dak.

Minnesota Highway 317-North Dakota Highway 17 bridge

Middle-Snake Rivers, Minn.

Forest River, N. Dak.

Marais River, N. Dak.

U.S. Geological Survey streanflow-gaging station at 0slo, Minn.

Minnesota Highway 1-North Dakota Highway 54 bridge, Oslo, Minn.

Soo Line Railroad bridge

Turtle River, N. Dak.

Grand Marais Creek, Minn.

Grand Marais Creek ditch outlet, Minn.

U.S. Geological Survey streamflow-gaging station at Grand Forks, N. Dak.

Riverside Dam

U.S. Highway 2 bridge

Northern Pacific Railroad bridge

Demer Avenue bridge

Great Northern Railroad bridge

236.0

230.2

243.3

246.8

271.2

271.2

271.25

Red Lake River, Minn.

Minnesota Avenue-5th Street bridge

Polk County State Aid Highway 9-Grand Forks County Road B7 bridge

Polk County State Aid Highway 7-Traill County Road 21 bridge, Climax, Minn.

Sandhill River, Minn.

Polk County State Aid Highway 1-Traill County Road 17 bridge near Nielsville, Minn.

Marsh River, Minn.

Goose River, N. Dak.

285.6
287.5

287.5

296.1

296.95

297.55

297.6

297.8

Norman County State Aid Highway 3-Traill County Road 13 bridge near Shelly, Minn., and

298.0

298.1

317.7

335.45

336.3

347.65

357.1

357.9

Caledonia, N. Dak.

U.S. Geological Survey streamflow-gaging station at Halstad, Minn.

358.9

Minnesota-North Dakota Highway 200 bridge

Wild Rice River, Minn.

Norman County State Aid Highway 25-Traill County Road 1 bridge near Hendrum, Minn.

Elm River, N. Dak.

Norman County State Aid Highway 39-Cass County Road 26 bridge, Perley, Minn.

375.2

375.2

380.3

386.3

387.2

403.6

Clay County State Aid Highway 36-Cass County Road 34 bridge, Georgetown, Minn. 415.9 Buffalo River, Minn.

Sheyenne River, N. Dak.

Clay County State Aid Highway 22-Cass County Road 20 bridge

417.1

427.5

(North Broadway Street), Fargo, No Dak.

Dam A

Great Northern Railroad bridge

First Avenue bridge

440.0

448.9

450.85

Northern Pacific Avenue bridge (U.S. Highway 10)

Northern Pacific Railroad bridge $\quad 451.65$

Main Avenue-lst Avenue bridge 451.7

Mam 1 -

Dam 1

U.S. Geological Survey streamflow-gaging station at Fargo, N. Dak.

451.7

452.15
453.0

455.4

Dam 2

Clay County Road 74 bridge

458.1

Wild Rice River, N. Dak.

Clay County Road 65 bridge

Clay County State Aid Highway 8-Cass County Road 16 bridge

Dam 3

Clay County State Aid Highway 2-Cass County Road 18 bridge

Wilkin County Road 90 bridge

Wilkin County State Aid Highway 30-Richland County Road 2 bridge near Wolverton, Minn., and Christine, N. Dak.

Wilkin County State Aid Highway 28-Richland County Road 4 bridge

Wilkin County State Aid Highway 22-Richland County Road 28 bridge near Kent, Minn., and

462.05

Abercrombie, N. Dak.

Wilkin County State Aid Highway 18-Richland County Road 8 bridge, Brushvale, Minn.

Great Northern Railroad bridge

Kidder Dam

U.S. Geological Survey streamflow-gaging station at Wahpeton, N. Dak.

Confluence Ottertail-Bois de Sioux Rivers 


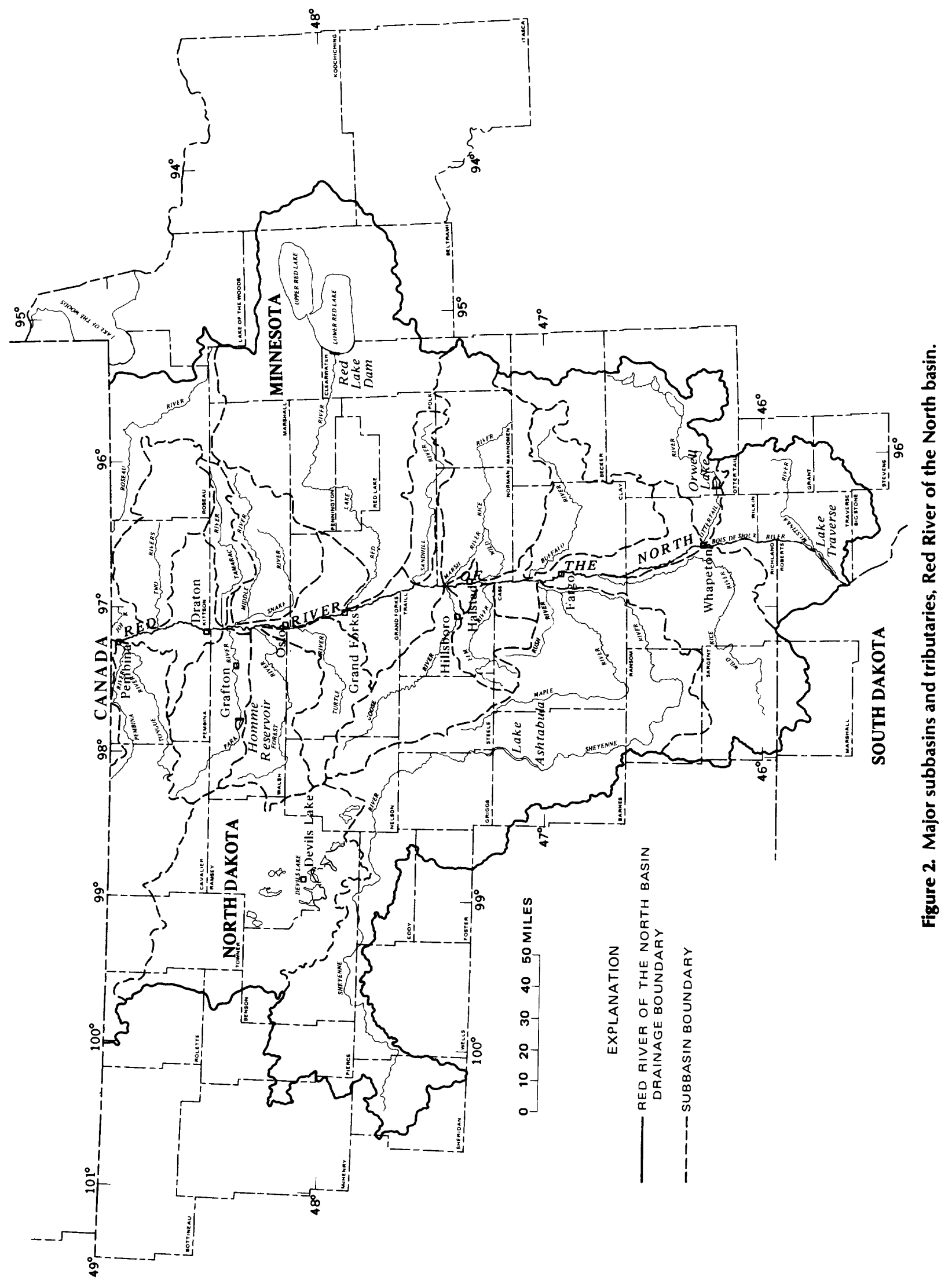

Part 1-Hydrologic setting 5 
Table 2. Total land area according to land use for the Red River of the North basin in the United States

[Souris-Red-Rainy River Basin Commission, 1972a, p. 19]

\begin{tabular}{lcc}
\hline \multicolumn{1}{c}{ Land use } & $\begin{array}{c}\text { Area, in } \\
\text { square miles }\end{array}$ & $\begin{array}{c}\text { Percentage } \\
\text { of basin }\end{array}$ \\
\hline Cropland & 25,722 & 66 \\
Pasture and rangeland & 3,328 & 8 \\
Other agriculture & 1,911 & 5 \\
Forest land & 4,625 & 12 \\
Recreation & 41 & 2 \\
Wildlife & 716 & 3 \\
Water areas & 1,166 & 1 \\
Miscéllaneous lands & 564 & 3 \\
Urban and built-up areas & 1,127 & 100 \\
\hline Total & 39,200 & than \\
\hline
\end{tabular}

Table 3. Listing of approximate water-surface elevations at flood stage along the Red River of the North [Simons and King, 1922, p. 4; and U.S. Army Corps of Engineers, 1977, plate 32]

\begin{tabular}{lc}
\hline \multicolumn{1}{c}{ Location } & Elevation \\
\hline Lake Traverse & 980 \\
Wahpeton & 955 \\
Fargo & 900 \\
Halstad & 859 \\
Grand Forks & 825 \\
Oslo & 810 \\
Drayton & 796 \\
International boundary & 789 \\
Winnipeg, Manit toba \\
(62 miles north of \\
international boundary)
\end{tabular}

topography: (1) The level plain (Red River valley) that borders the river and is $15 \mathrm{mi}$ wide in the south and 60 to $70 \mathrm{mi}$ wide in the north and (2) the rougher upland areas extending east and west of the plain. The level plain border loses its identity in the east, north of the Red Lake basin.

Elevations in the basin range from about $2,300 \mathrm{ft}$ in the Turtle Mountains, in northern Bottineau and Rolette Counties, to about $750 \mathrm{ft}$ at the river at the international boundary. In the southwest, the plain rises nearly uniformly to the upland areas, whereas in the northwest the gentle slopes of the valley terminate abruptly at the Pembina Escarpment. In the northwest the Pembina Escarpment extends from the boundary of Cavalier and Pembina Counties, in the north, roughly parallel to the Red River, southward through the boundary of Steele and Traill Counties. In the southeast the plain is bounded by hilly areas that merge into the lakes and swamps of the
Table 4. Significant tributaries of the Red River of the North, listed in order from south to north

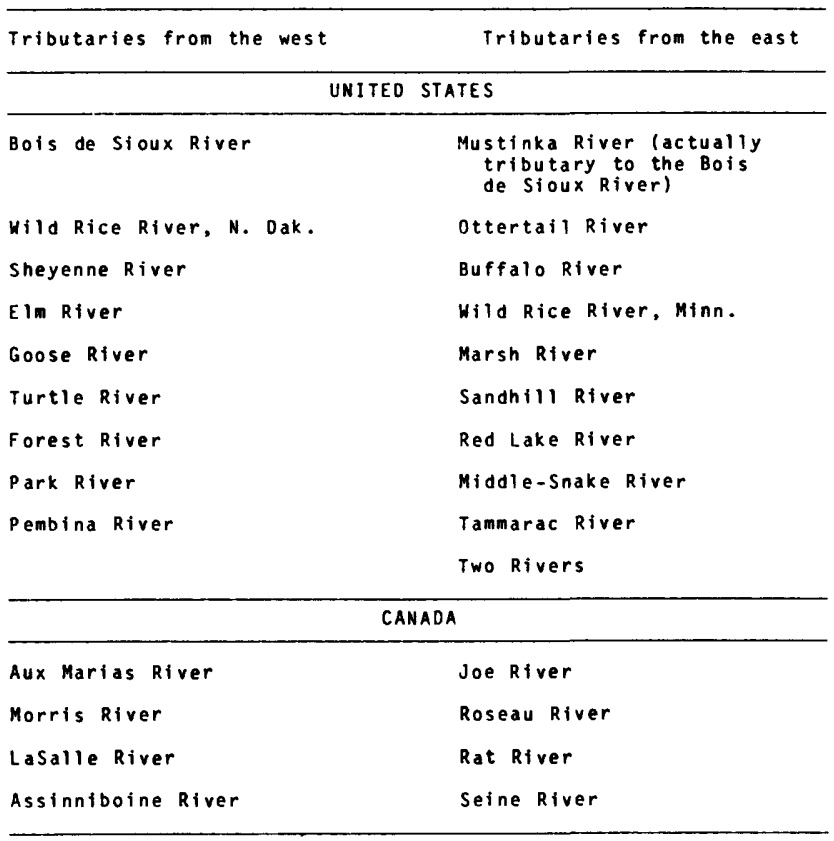

upland areas, whereas in the northeast the upland area is very flat and includes extensive swamp areas.

The basin is approximately as wide as it is long. Even such tributaries as the Bois de Sioux above Wahpeton, the Buffalo River, the Goose River, the Red Lake River above Crookston, the Two Rivers, and the Minnesota Wild Rice River above Twin Valley have drainage areas that are almost as wide as they are long. On other tributary streams-the Ottertail, Sheyenne, Sand Hill, and Pembina Rivers-the ratio of width to length is small.

The Red River valley, unlike the tributary valleys, was not shaped by the streams that presently drain and erode its surface. Its topography is, instead, almost entirely the product of Lake Agassiz. Lake Agassiz was produced by melting of the glaciers during the glacial period. Sediment from the tributary streams settled in the lake to form the wide, flat valley floor. Although the Red River has a well-defined meander belt, the flood plain extends without easily recognizable relief across the lakebed. The channel of the Red River is small in relation to the size of the watershed it drains (U.S. Army Corps of Engineers, 1978).

The surface slope of the upland areas is much greater than that of the valley. However, the upland areas are still a relatively level area hydrologically (Simons and King, 1922, p. 39). The uplands include noncontributing areas such as lakes, ponds, and other depressional storage areas. 
The slope of the Red River main stem ranges from about $1.3 \mathrm{ft} / \mathrm{mi}$ at Wahpeton-Breckenridge to only 0.2 $\mathrm{ft} / \mathrm{mi}$ at the international boundary. The river drops about $200 \mathrm{ft}$ in its $395-\mathrm{mi}$ course from Wahpeton to the boundary. Bank-full channel capacities at cities on the main stem are Wahpeton-Breckenridge, $3,100 \mathrm{ft}^{3} / \mathrm{s}$; Fargo-Moorhead, 7,000 ft ${ }^{3} / \mathrm{s} ;$ Halstad, 16,500 $\mathrm{ft}^{3} / \mathrm{s}$ (Souris-Red-Rainy River Basin Commission, 1972 b, p. D125); Grand Forks-East Grand Forks, $27,000 \mathrm{ft}^{3} / \mathrm{s}$; Oslo, 20,000 $\mathrm{ft}^{3} / \mathrm{s}$; Drayton, 25,000 $\mathrm{ft}^{3} / \mathrm{s}$; and PembinaEmerson, 35,000 ft $3 / \mathrm{s}$ (U.S. Army Corps of Engineers, 1977, p. 8). Channel widths vary from 200 to $500 \mathrm{ft}$, and depths at bank-full stage range from 10 to $30 \mathrm{ft}$ (U.S. Army Corps of Engineers, 1956a, p. 6). Elevations at flood stage along the Red River are given in table 3.

Significant tributaries of the Red River are listed in table 4. Detailed descriptions of the tributary streams are given in the Souris-Red-Rainy River Basin Commission Comprehensive Study (1972b) and in Upham (1895). The tributaries of the Red River all have similar characteristics. They generally rise in the upland areas on the extremities of the basin and flow on relatively steep gradients as they approach the broad river flood plain where gradients are virtually flat.

\section{Geologic setting}

The oldest and deepest rocks underlying the Red River basin are of igneous origin and Precambrian age, and lie at depths ranging from near land surface at the southern end of Lake Traverse and near the eastern edge of the basin (Bidwell and others, 1970, sheet 2) to as much as $6,000 \mathrm{ft}$ below land surface in the northwestern part of the basin (Carlson and Freers, 1975, p. 5). The Precambrian rocks are overlain by sedimentary rocks ranging in age from Ordovician to Holocene (recent deposits).

Shale and other fine-grained rocks of Cretaceous age belonging to the Colorado Group and equivalent of the Montana Group probably form the bedrock beneath unconsolidated glacial drift in most of the basin. However, information concerning distribution of the bedrock formations, particularly east of the Red River, is incomplete. Carlson's (1973) map shows bedrock of Precambrian, Ordovician, and Jurassic age along the eastern edge of North Dakota. Presumably these rocks extend into Minnesota.

Shale beds belonging to the Carlile Shale and Niobrara Formation (Colorado Group) and the Pierre Shale (equivalent of Montana Group) crop out in the valleys of the Pembina (Arndt, 1975, p. 5-8) and Sheyenne (Kelly and Block, 1967, p. 8) Rivers. Recently, a small outcrop of the Greenhorn Formation (calcareous shale) of the Colorado Group was identified in the Pembina River valley near the Cavalier-Pembina County line (Robert
Whartman, oral commun., September 1980). This formation, which underlies the Carlile, is the oldest formation known to crop out in North Dakota.

Nearly the entire basin is thickly mantled by glacial drift, which comprises two rather distinct land forms. These land forms consist of a remarkably flat, northwardsloping, central plain, commonly referred to as the Red River valley, and a gently rolling upland, dotted with prairie potholes and other undrained depressions, on each side of the plain. In northern North Dakota, the boundary between the two is marked by an eastwardfacing scarp several hundred feet high called the Pembina Escarpment. Elsewhere, the boundary is generally defined by low beach ridges or scarps along the periphery of the plain.

The term Red River valley is somewhat of a misnomer. The "valley" is, as has been noted earlier, a lake plain formed by glacial melt waters ponded along the southern edge of a massive, glacial ice lobe that occupied the area some 10,000 to 15,000 years ago. The extinct lake was named Lake Agassiz in memory of Professor Louis Agassiz who, according to Upham $(1895$, p. 5), was the first prominent advocate of the theory that glacial drift was produced by land ice.

The glacial drift in the uplands consists mainly of an unsorted and unstratified mixture of clay, silt, sand, and gravel, commonly referred to as till. In most places, clay and silt are the dominant lithologies of till. Deposits of sorted and stratified sand and gravel, termed glacial outwash, are interspersed with the till both on and beneath the land surface. In the Red River valley, the till is overlain by as much as $95 \mathrm{ft}$ of lake deposits (Hansen and Kume, 1970, p. 55) consisting of sorted and stratified clay and silt formed in glacial Lake Agassiz. The former shorelines of the lake are marked by low beach ridges or scarps that can be traced for many miles in a generally northwesterly direction in North Dakota and a northerly or northeasterly direction in Minnesota. The beach ridges are underlain by deposits of sorted and stratified sand and gravel generally a few feet thick but, in a few places, as much as $20 \mathrm{ft}$ thick.

Deposits of Holocene age have been formed in parts of the Red River basin in stream valleys, lakes, and marshes and as dunes. The water-laid deposits generally consist of organic-rich clay and silt. The dunes, consisting of fine- to medium-grained sand, are prevalent in Richland (Baker, 1967, p. 34) and Ransom Counties, N. Dak.

\section{Climate}

The Red River basin experiences cold winters and moderately warm summers. The annual mean temperature is about $40^{\circ} \mathrm{F}$. Approximately 60 percent of the total annual precipitation falls during the growing season, 
which lasts for 100 to 140 days. The average growing season is approximately 110 days. The range between annual maximum temperature and annual minimum temperature is $101^{\circ}$ to $141^{\circ} \mathrm{F}$. Maximums of $101^{\circ}$ to $118^{\circ} \mathrm{F}$ have occurred in August, and minimums of $-34^{\circ}$ to $-55^{\circ} \mathrm{F}$ have occurred in January and February. Mean annual precipitation ranges from $24 \mathrm{in}$. in the southeast to 17 in. in the northwest (U.S. Department of Commerce, 1973; Bavendick, 1959, p. 811-825; Stewart, 1907; and U.S. Army Corps of Engineers, 1956a, p. 10). The winter months, December through February, usually are the driest, and the greatest amount of precipitation occurs during the period May through August. Precipitation in winter generally occurs as snow and constitutes about 15 percent of the total annual amount.

The Red River basin lies in a belt of prevailing westerly winds and is located in the center of the continental area well beyond the leeward side of the Rocky Mountains. As a result, the precipitation of the basin is generally associated with local storms occurring in cyclonic areas that move eastward across the basin. Large summer storms that cover a great percentage of the Red River basin are rare.

A number of storms of major proportions have been observed and are worthy of note. During the period from July 18 to 22,1897 , heavy precipitation was recorded throughout the basin, with a maximum of 8 in. in 72 hours at the storm center in the Red Lake basin. During the period from July 1 to 6,1901 , a small center of intense precipitation-10 in. in 72 hours-occurred northeast of Grand Forks, N. Dak. A very intense storm of record in the basin was centered near Beaulieu, Minn., in the Wild Rice River basin during the period from July 18 to 23, 1909. This storm covered an area extending from the Red River across Minnesota into Wisconsin and northern Michigan. Approximately $10.5 \mathrm{in}$. of rain fell in the storm center during a 6-hour period (U.S. Army Corps of Engineers, 1956a, p. 10). During a storm of July 1 to $4,1919,9$ in. of rain fell in 4 days over an area of about $390 \mathrm{mi}^{2}$ in the extreme northeastern part of the basin, and amounts ranging from 1 to $9 \mathrm{in}$. were recorded over 2,000 to $8,000 \mathrm{mi}^{2}$. Maps showing isohyetals for the storms of 1897, 1909, and 1919 are given by Simons and King (1922, p. 32-36). A storm centered near Grafton, N. Dak., in September 1957 produced about 7.4 in. of rain in the maximum 24-hour period (Souris-Red-Rainy River Basin Commission, 1972b, p. D-40).

A series of storms occurred from June 27 to July 5 , 1975, in a band from southeastern North Dakota to northwestern Minnesota. The greatest total precipitation was 20.6 in. reported about $25 \mathrm{mi}$ southwest of Fargo, N. Dak. During this period, four storms were particularly important, occurring on June 28 and 29 , June 30 , July 1 , and July 4 . This series of storms produced a summer flood on the Red River (Robert G. Barnicle, National Weather Service, written commun., 1981).

In general, excessive storm precipitation rarely occurs at one time over a large percentage of the Red River basin. Bavendick (1952, p. 53-64) gave a number of precipitation statistics. He noted a significant natural variation in total annual precipitation. Upham (1895, p. 593), Wilde (1945), and Simons and King (1922, p. 23) also noted this variation. For example, from 1933 through 1936 precipitation over the eastern third of North Dakota (western half of the Red River basin) averaged 14.67 in., while from 1941 through 1944 it averaged 22.73 in. This variation in precipitation has caused variation in crop production in the valley. However, because of the moisture-holding capacity of the soil in the basin, even the driest years produce crops.

The relationship between prevailing temperatures and precipitation and runoff was studied in detail by Simons and King (1922, p. 40). They stated that the relationship of temperature to the magnitude of the spring floods depends on (1) the rate and amount of the temperature changes, and (2) whether the temperature rises simultaneously over the whole or a large part of the valley or progressively from the upper to lower part of the watershed. Because the Red River flows north, some investigators have argued that if snow covers large parts of the watershed a rise in temperature that moves gradually northward will tend to cause a greater flood than will a simultaneous temperature rise in all parts of the area. However, numerous other processes control the timing of runoff from the tributaries.

Winds over the basin on many days are strong and almost continual. The mean wind speed is $14.4 \mathrm{mi} / \mathrm{h}$ at Fargo, N. Dak. This is the fastest mean wind speed in the contiguous 48 States (U.S. Department of Commerce, 1977, p. 78).

Based on evaporation records made by E.F. Chandler at Fargo, Stewart (1907, p. 22) stated that although the potential for evaporation is large at times, usually only a small amount of water is evaporated during flood periods.

\section{Localized Excess-Water Problems}

One result of the flat topography of the Red River basin is excess water on agricultural lands. The basin experiences two types of water problems-streambank overflows and localized excess water. These excess-water problems can be grouped into three categories (SourisRed-Rainy River Basin Commission, 1972b, p. E-3). The first problem is flooding that occurs when rainfall or snowmelt exceeds the infiltration capacity of the soil, fills the surface depressions, and runs off the basin at a rate exceeding the stream channel capacity. The second prob-

\section{Flood Response, Red River, N.Dak-Minn.}


lem is ponding of water in shallow depressions that occurs after flooding as a result of a seasonally high water table or rainfall. Under natural conditions, the ponded water is removed slowly by seepage and evaporation. Often, this removal is too prolonged to permit efficient use of the land for crops. The third problem is the large amount of free water held internally in the soil due to slow percolation rates or high water tables. This problem is most prominent in the fine-grained soils. Fargo clays and Beardens are typical soils in this group.

Within the Red River basin, there are extensive areas of soils with excess-water problems that limit the use of the land for cultivated crops or pasture, mainly due to the geologic setting of the basin (Souris-Red-Rainy River Basin Commission, 1972b, p. E-11-13). These areas include the glaciated pothole areas, the lake-plain areas, and the peat-bog areas. The pothole areas contain soils with a major wetness condition (very poorly drained so that excess water limits use for cultivated crops or pasture). The glacial lake-plain areas contain soils with a minor wetness condition (poorly drained so that excess water is a minor problem for cultivated crops or past ure). These soils occur on broad lake plains and in shallow potholes where the water recedes too slowly for adequate drainage. The peat-bog areas contain organic soils formed from partly decomposed plant remains. The Souris-Red-Rainy River Basin Commission (1972b, p. $\mathrm{E}-12)$ has mapped the location of these areas.

\section{Flood Characteristics}

The flood characteristics of the Red River basin are described by providing a review of currently available information concerning streambank overflows. The complexity of the runoff is shown by describing the controlling processes that determine the magnitude of snowmelt runoff, rainfall runoff, depressional storages, and floods. Recorded and historical floods are described to show the expected natural variation in the magnitude of floods with time.

The Red River main stem experiences flooding during two critical hydrologic periods-snowmelt or rainfall or both. The magnitude of a flood that occurs during these periods is determined by controlling snowmelt-runoff and rainfall-runoff processes.

Based on a study of records for 1948, 1950, 1965, 1966, 1969, and 1978 floods, the U.S. Army Corps of Engineers (1978, p. 72-73) tabulated the percentage of total flood volume and drainage area contributed by the tributaries of the Red River. These data are presented in tables 5 and 6 . From these data, it is apparent that the Red Lake River is the largest contributor and the Sheyenne River is the second largest contributor of total flood volume to the Red River measured at Grand Forks.
Table 5. Percentage of total flood volume contributed by the tributary rivers to the Red River of the North at four locations on the main stem-values averaged for the 1948, 1950, 1965, 1966, and 1969 floods

[U.S. Army Corps of Engineers, 1978, p. 72]

\begin{tabular}{|c|c|c|c|c|}
\hline & Aver & $\begin{array}{l}\text { ge percent } \\
\text { contrit }\end{array}$ & $\begin{array}{l}\text { flood } \\
\text { ution }\end{array}$ & olume \\
\hline Tributaries & $\begin{array}{c}\text { Wahpeton- } \\
\text { Breckenridge }\end{array}$ & $\begin{array}{c}\text { Fargo- } \\
\text { Moorhead }\end{array}$ & $\begin{array}{l}\text { Grand } \\
\text { Forks - } \\
\text { East } \\
\text { Grand } \\
\text { Forks }\end{array}$ & $\begin{array}{c}\text { Internationa } \\
\text { boundary }\end{array}$ \\
\hline \multicolumn{5}{|l|}{ MINNE SOTA } \\
\hline $\begin{array}{l}\text { Bois de Sioux } \\
\text { Ottertail } \\
\text { Buffalo } \\
\text { Wild Rice-Marsh } \\
\text { Sand Hill } \\
\text { Red Lake } \\
\text { Middle-Snake } \\
\text { Tamarac } \\
\text { Two Rivers } \\
\text { Minor tributaries }\end{array}$ & $\begin{array}{l}59 \\
41 \\
-- \\
-- \\
-- \\
-- \\
-- \\
-- \\
--\end{array}$ & $\begin{array}{l}37 \\
25 \\
-- \\
-- \\
- \\
-- \\
-- \\
- \\
10\end{array}$ & $\begin{array}{r}8 \\
5 \\
5 \\
9 \\
3 \\
35 \\
-- \\
- \\
6\end{array}$ & $\begin{array}{r}5 \\
3 \\
3 \\
6 \\
2 \\
23 \\
4 \\
1 \\
4 \\
9\end{array}$ \\
\hline Total & 100 & 72 & 71 & 60 \\
\hline \multicolumn{5}{|l|}{ NORTH DAKOTA } \\
\hline $\begin{array}{l}\text { Wild Rice, } \\
\text { Sheyenne- } \\
\text { Elm } \\
\text { Goose } \\
\text { Turtle } \\
\text { Forest } \\
\text { Park } \\
\text { Pembina } \\
\text { Minor tributaries }\end{array}$ & $\begin{array}{l}-. \\
-- \\
-\therefore \\
\therefore \\
\therefore \\
-- \\
--\end{array}$ & $\begin{array}{r}15 \\
7 \\
-- \\
-- \\
-- \\
-- \\
- \\
- \\
6\end{array}$ & $\begin{array}{r}4 \\
13 \\
2 \\
6 \\
-- \\
-- \\
-- \\
- \\
4\end{array}$ & $\begin{array}{l}3 \\
8 \\
1 \\
4 \\
2 \\
3 \\
4 \\
9 \\
6\end{array}$ \\
\hline Total & 0 & 28 & 29 & 40 \\
\hline $\begin{array}{l}\text { Red River } \\
\text { basin total }\end{array}$ & 100 & 100 & 100 & 100 \\
\hline
\end{tabular}

The tributaries of the Red River all have similar flood characteristics except that the larger number of lakes in the eastern half of the basin modifies runoff peaks. The U.S. Army Corps of Engineers (1973, p. 9) described flooding on the Park River, which is typical of the Red River tributaries, as follows: The maximum discharges of the year commonly occur in late March or in April, following the spring snowmelt runoff. Occassionally, these high flows are increased and prolonged by accompanying rains. Runoff in the basin decreases during the summer months, and frequently cessation of flow occurs during the winter months.

Many statements have been made concerning the timing of flood runoff on the tributaries and how the timing affects the peaks on the main stem. Because the Red River basin is as wide as it is long and because the river flows northward (warm temperatures and thus snowmelt runoff move northward slowly), the timing of the flows on the tributaries closely coincides with that on the main stem, adding to the peaks. However, the timing of the peaks is likely to be different every year during which a flood occurs. Because of the complexity of the runoff processes, the effect of timing could probably be characterized only with the use of a basin-wide flow 
Table 6. Contribution of effective (contributing) drainage area from tributary rivers at key locations on the Red River of the North main stem

[U.S. Army .Corps of Engineers, 1978, p. 73]

\begin{tabular}{|c|c|c|c|c|}
\hline \multirow[b]{2}{*}{ Tributaries } & \multicolumn{4}{|c|}{$\begin{array}{l}\text { Tributary drainage } \\
\text { area contribution (in percent) }\end{array}$} \\
\hline & $\begin{array}{c}\text { Wahpeton- } \\
\text { Breckenridge }\end{array}$ & $\begin{array}{c}\text { Fargo- } \\
\text { Moorhead }\end{array}$ & $\begin{array}{l}\text { Grand } \\
\text { Forks- } \\
\text { East } \\
\text { Grand } \\
\text { Forks }\end{array}$ & $\begin{array}{c}\text { International } \\
\text { boundary }\end{array}$ \\
\hline \multicolumn{5}{|l|}{ MINNE SOTA } \\
\hline $\begin{array}{l}\text { Bois de Sioux } \\
\text { ottertail } \\
\text { Buffalo } \\
\text { Wild Rice-Marsh } \\
\text { Sand Hill } \\
\text { Red Lake } \\
\text { Middle-Snake } \\
\text { Tamarac } \\
\text { Two Rivers } \\
\text { Minor tributaries }\end{array}$ & $\begin{array}{l}52.2 \\
47.8 \\
-- \\
-- \\
-- \\
-- \\
-- \\
-- \\
--\end{array}$ & $\begin{array}{l}33.6 \\
31.0 \\
-- \\
-- \\
-- \\
-- \\
-- \\
\overline{8.9}\end{array}$ & $\begin{array}{l}8.8 \\
8.1 \\
5.0 \\
8.3 \\
2.0 \\
20.6 \\
-- \\
-- \\
-- \\
6.0\end{array}$ & $\begin{array}{r}6.5 \\
6.0 \\
3.7 \\
6.2 \\
1.5 \\
15.3 \\
3.0 \\
1.0 \\
3.5 \\
4.7\end{array}$ \\
\hline Total & 100 & 73.5 & 58.8 & 51.4 \\
\hline \multicolumn{5}{|l|}{ NORTH DAKOTA } \\
\hline $\begin{array}{l}\text { Wild Rice } \\
\text { Sheyenne } \\
\text { Elm } \\
\text { Goose } \\
\text { Turtie } \\
\text { Forest } \\
\text { Park } \\
\text { Pembinal } \\
\text { Minor tributaries }\end{array}$ & $\begin{array}{l}-- \\
-- \\
-- \\
-- \\
-- \\
-- \\
--\end{array}$ & $\begin{array}{c}26.5 \\
- \\
-- \\
-- \\
-- \\
\cdots \\
-\end{array}$ & $\begin{array}{l}6.9 \\
20.8 \\
2.1 \\
4.9 \\
-- \\
-. \\
-- \\
-- \\
6.5\end{array}$ & $\begin{array}{r}5.2 \\
15.5 \\
1.6 \\
3.7 \\
2.1 \\
2.9 \\
3.2 \\
10.4 \\
4.0\end{array}$ \\
\hline Total & 0 & 26.5 & 41.2 & 48.6 \\
\hline
\end{tabular}

1/Includes 195,360 , and 1,533 square miles located in North

2 Dakota, South Dakota, and Minnesota.

flows to the Red River maln area in canada which contributes flows to the Red River main stem within the United States.

model of the major streams.

Bridges and other channel obstructions such as levees, dams, ice jams, trees, brush, and sediment can cause localized increases in flood elevations due to backwater effects. The U.S. Army Corps of Engineers (1977, p. 13) studied high-water marks for the 1950, 1969, and 1975 floods at seven bridges across the Red River between Grand Forks and Pembina to determine whether these bridges had any significant effect on flood elevations. The profile for the 1969 flood at Grand Forks shows that only the four bridges between river miles 297 and 298 restricted the flow of the water and caused a significant increase in flood elevations. This amounted to about $1 \mathrm{ft}$ upstream of the Highway 2 bridge at river mile 296.95. The U.S. Army Corps of Engineers (written commun., 1981) has analyzed the effects of bridges on flood levels between Grand Forks and the international boundary for the 1-percent annual exceedance probability flood. Numerous bridges have minor effects on the flood elevations for the 1-percent flood.

\section{Controlling processes}

The processes that control the flood magnitude on the Red River basin are numerous and complex. These processes and the factors that affect them are listed in table 7. The processes are divided into three groups. The water-availability processes make water available to begin running off the basin. The water-excess processes reduce the amount of water from that which is available to that which is in excess and actually runs off. The water-routing processes determine the direction and speed that the excess water runs off.

Two water-availability processes are listed-rainfall and snowmelt. This study is mainly concerned with the snowmelt processes because most floods on the Red River occur during the snowmelt period. However, a discussion of the rainfall process is warranted.

Because of the small chance that a large volume of water will be distributed over the entire Red River basin in a short period of time, rainfall events generally do not produce large floods on the main stem. They can produce significant floods in rare instances, commonly following extremely wet spring runoff conditions like those noted in 1950. However, excessive rainstorms can cause floods on any of the tributaries of the Red River, including the Bois de Sioux and Ottertail Rivers. Summer floods are often more disastrous because of the crops that can be flooded and the suddenness with which they occur. This occurred in 1897 and in 1975.

Runoff from rainfall is especially subject to the water-excess processes, which determine the volume of runoff (table 7). Infiltration, evapotranspiration, pocket storage, and interception will significantly reduce the volume of water available before it becomes water excess during all but the wettest conditions in the Red River basin. After becoming water excess, runoff from rainfall is still subject to all of the water-routing processes.

Because of the greater likelihood of having a large volume of available water over the basin during snowmelt as compared with rainfall, the largest floods on the Red River main stem occur during snowmelt periods. Snowmelt can cause floods on the Red River main stem and any of the tributaries during March, April, and even May.

The snowmelt process is described in detail by the U.S. Army Corps of Engineers (1956b and 1960) and Eagleson (1970, p. 243-259). Antecedent factors that affect the snowmelt process are the areal variability, temperature, and density of the snowpack; the air, water, and heat transfer and storage properties of the snowpack; the formation of ice planes; the exposure; and the soil temperature. These factors determine the properties of the snowpack at the beginning of melt periods when the snowpack is ripe. It is considered ripe when it contains all the water it can hold against gravity and when any further melt will result in water available to begin to run off.

These factors are determined over the winter period by heat exchange at the snow surface due to radiation, 
Table 7. Hydrologic processes and the factors affecting the processes that control the magnitude of floods in the Red River of the North basin

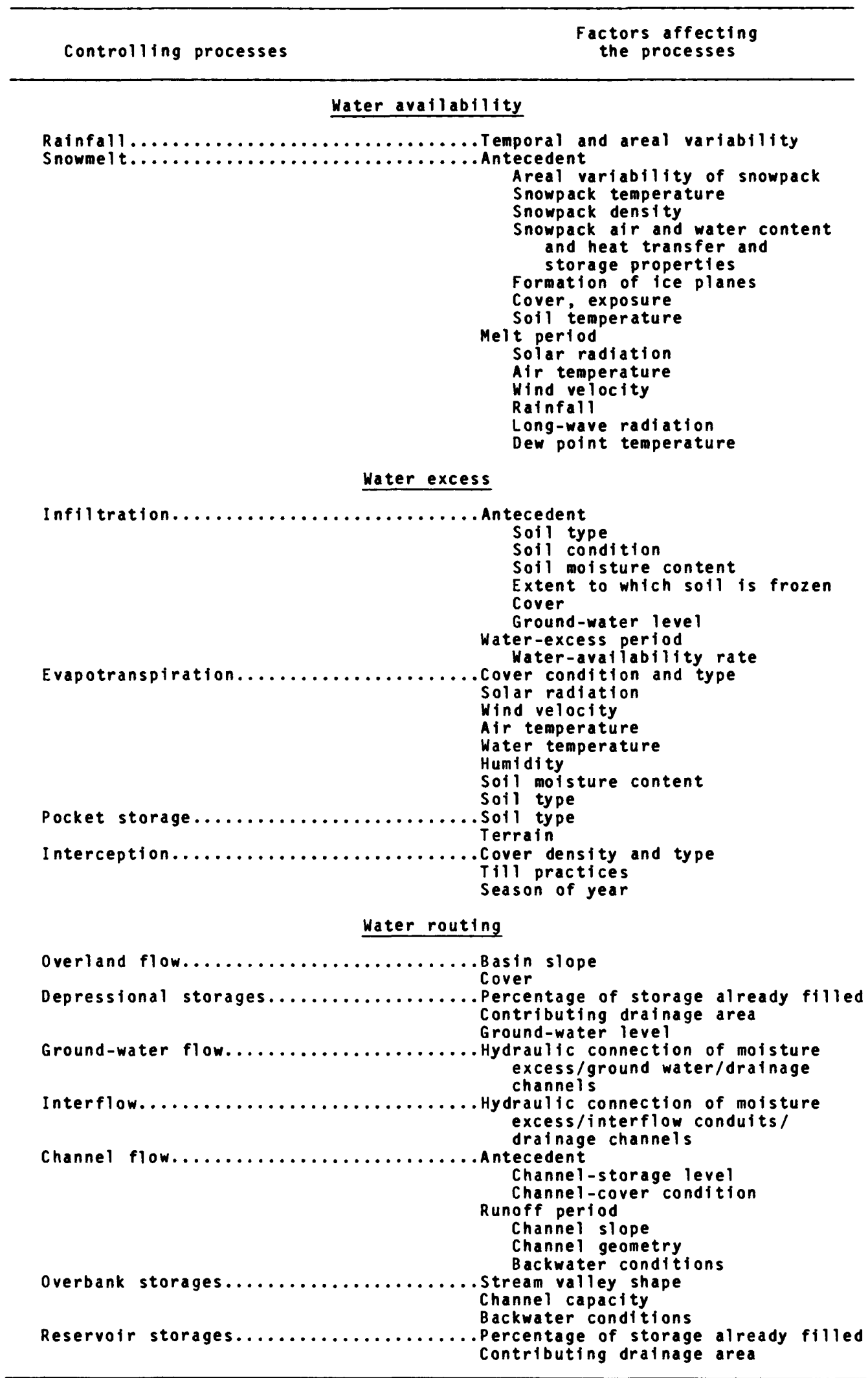


convection, and condensation, and at the ground surface by conduction, compaction by its own weight, percolation of rain or melt water through the snowpack, redistribution due to wind, and temperature and water-vapor variations within the snowpack. Air temperature and wind speed are the primary factors affecting the density of new snow. Eagleson (1970, p. 244) reported density variations due to wind from $0.06 \mathrm{~g} / \mathrm{cm}^{3}$ (gram per cubic centimeter) to $0.34 \mathrm{~g} / \mathrm{cm}^{3}$, and stated that an average value of $0.10 \mathrm{~g} / \mathrm{cm}^{3}$ is satisfactory for engineering use.

The melt process can be understood by considering the snowpack heat budget as given by Eagleson (1970, p. 253).

$$
M=\frac{1}{203.2 \theta}\left(H_{\mathrm{rs}}+H_{\mathrm{r}}+H_{\mathrm{c}}+H_{\mathrm{e}}+H_{\mathrm{g}}+H_{\mathrm{p}}\right)
$$

where

$M=$ snowmelt in inches;

$\theta=$ thermal quality of the snowpack at the beginning of the melt time interval-that is, ratio of heat necessary to produce a given amount of water from snow to amount of heat needed to produce the same quantity of melt from pure ice at $0^{\circ} \mathrm{C}$;

$H_{\mathrm{rs}}=$ absorbed shortwave solar radiation, in langleys;

$H_{\mathrm{rl}}=$ net longwave radiation exchange between snowpack and its environment,-in langleys;

$H_{\mathrm{c}}=$ convective transfer of sensible heat from air, in langleys;

$H_{\mathrm{e}}=$ release of latent heat of vaporization by condensate, or, with negative sign, its removal by sublimation, in langleys;

$H_{\mathrm{g}}=$ conduction of heat from underlying ground, in langleys; and

$H_{\mathrm{p}}=$ advection of heat by rain, in langleys;

203.2 $=$ conversion factor $(203.2$ ly are required to produce 1 in. of melt if $\theta=1$ ).

Langley is a unit of energy density; 1 langley is equal to 1 calorie per square centimeter.

Solving equation 1 determines the water availability due to snowmelt. As can be seen from table 7, the available water is still subject to all of the water-excess and waterrouting processes before it becomes part of a snowmeltrunoff flood flow. The factors given above show that production of available water by snowmelt is a complex process that cannot easily be characterized using simple parameters such as total annual precipitation or mean monthly temperatures. Instead, snowmelt events are controlled by other parameters that may vary greatly from year to year.

Four water-excess processes are listed-infiltration, evapotranspiration, pocket storage, and interception. A number of factors affect the processes that determine the amount of water and the rate at which the water becomes excess and runs off. The water-excess processes (table 7) are particularly variable during the snowmelt period. For example, because the ground is usually frozen to some extent, the infiltration process is highly variable. The infiltration rate can vary due to both soil-moisture content and the extent to which the soil is frozen. The term pocket storage is used here to describe water stored at the surface in storages ranging in size from very small to puddle sized. It is used to differentiate between this water-excess process and the depressional storages listed as a water-routing process. Depressional storages are prairie potholes and other small lake-sized depressions. Pocket storages are a result of small-scale variations in the land surface and are present even in steeper areas lacking depressional storage. The water-excess processes are complex, and their influence on runoff is not easily characterized in an analysis of Red River flooding.

Seven water-routing processes are listed-overland flow, depressional storages, ground-water flow, interflow, channel flow, overbank storages, and reservoir storages. A number of factors affect the processes that determine the direction and speed of excess water runoff from the basin. The water-routing processes (table 7), like the water-excess processes, are particularly variable during the snowmelt period. For example, because the condition of the ground cover can vary from ice-covered or snow-covered to bare soil, the rate of overland flow is highly variable. The water-routing processes are complex, and their influence on runoff is not easily characterized in an analysis of Red River flooding.

The effect of depressional st orages on flood runoff is of particular interest because of their suspected significance. Many statements have been made concerning the flood-water-retention capability of depressional storages. However, these storages vary greatly in their hydrologic characteristics, and it is therefore difficult to make a general statement concerning the water-retention capabilities of a depressional storage. Rather, each storage has a different volume, shape, water balance, and waterretention capability. Also, each depressional storage has a different water-retention capability for each season and year. Depending on the season and the antecedent conditions, the storage may be very dry or nearly full. This will significantly affect its water-holding capacity.

Detailed studies of prairie potholes have been done in North Dakota. Sloan (1970, p. B-228) pointed out that potholes vary widely in hydrologic and topographic characteristics. The permanence of the ponds in potholes ranges from a few days following spring snowmelt to more or less permanent. Almost all are shallow, seldom exceeding 4 or 5 feet in depth. Commonly, they are less than 3 feet deep. 
A wide range of seepage conditions prevails in the prairie pothole region. Water level and quality in the potholes are controlled by the surface-water and groundwater relationship. Three different configurations are noted (Sloan, 1970, p. B-230)-ground-water outflow, throughflow, and inflow. Eisenlohr and others (1972, p. 100) stated that although water levels in potholes are related to ground-water levels, the low permeability of the till in which many of the potholes are located may prevent the relationship from being readily apparent. However, there may be an area of higher permeability confined to a narrow band around the perimeter of the pond. In places the till has vertical joints, which allow the ground water to move much faster vertically than horizontally.

A number of investigators have evaluated the floodresponse-change problem on the Red River by attempting to quantify the runoff process in a simple regression analysis or other approach. This is done to compare large floods that occurred before manmade drainage had become significant to large floods that have occurred since manmade drainage in the basin has increased. Often, simple hydrologic parameters were used to characterize the controlling processes such as total annual precipitation, winter precipitation, mean temperature, or a drainage factor. These simple parameters may be inadequate to describe the effect of these complex processes and factors.

Many processes control the magnitude of flooding. The effect of an individual process usually cannot be used at the exclusion of the others. For example, an analysis of the water-excess processes may show an increase in peak runoff from a small basin due to land-use change. However, this impact cannot be assumed to apply to the entire basin. Any changes in excess water on small subbasins of a large basin are still subject to all of the water-routing processes, which tend to attenuate increases in peak flow as the increases move downstream to the mouth of the basin.

\section{Historical and recorded floods}

Historical floods are those for which only legendary or narrative descriptions are available. Recorded floods are those for which systematic hydraulic data were collected. Historical and recorded floods on the main stem are listed in table 8. A detailed description of the available information and data on historical and recorded floods are given by the U.S. Geological Survey (1952) and the Canada Department of Resources and Development (1953, Appendix B).

The increase in magnitude and frequency of floods since 1950 as compared with the period from 1900 to 1950 has led to speculation that manmade drainage and other land-use changes have resulted in larger floods. However, this variation needs to be viewed in light of the expected natural variation in flood flows with time. A large variation in magnitude and frequency of floods with time is expected. This large variation can be seen in table 8 . A number of large floods at fairly frequent intervals were reported prior to 1900 . It is well documented that the 1826, 1852, and 1961 floods were all very large. The 1897 flood was larger than any flood that has occurred since 1900. A number of large floods have occurred since 1950.

The U.S. Department of Commerce $(1954$, p. 5) noted that floods of large magnitude occurred in the Upper Mississippi River basin in 1880, 1881, and 1888. In general, these remained the dominant floods until 1951. This is similar to the variation with time for the Red River of the North. This same relationship of historical peak timing on the Red and Mississippi Rivers can be seen in the tables presented by Paulhus (1971) and the U.S. Department of Commerce (1962). This similarity of the timing indicates that there has been some regional relationship in the water-availability processes between these two adjacent basins. Because the land-use changes that have occurred in the Red River basin are unique to this basin, this relationship indicates that at least part of the change in flood frequency in the last 30 years is due to a regionwide variation in the water-availability processes.

If a long period of record is examined, 20- to 30year periods during which flooding seems to increase or decrease are common. Benson (1960) used a theoretical 1,000 -year flood record to show the kinds of variation to be expected if a long-term flood record is compared to shorter term samples from the entire period. He drew a frequency curve on arithmetic Gumbel probability paper. From this curve, he read 1,000 annual peak discharges. These discharges were simply written on pieces of paper and placed in a box. Finally, 10010 -year samples, 40 25-year samples, 20 25-year samples, and 10 100-year samples were drawn. Flood-frequency curves based on the 10-, 25-, 50-, and 100-year sample records were then developed. All of the curves for each period of record were drawn on the same frequency plot for comparison. The variation to be expected based on 40 different 25 year records is shown in figure 3. A large variation in the frequency of floods is apparent when comparing periods as short as 25 years.

Some large floods have occurred on the Red River in the last 25 to 30 years. However, the variation in flood magnitudes needs to be viewed in light of the natural variation expected. Based on the large historical floods, the regional relationship in flood flows, and the variation shown by Benson, the floods of the last 30 years on the Red River may not be greater than those which fit within the expected natural variation in flood flows. 
Table 8. Major historical and recorded floods on the Red River of the North main stem

[All elevations are above National Geodetic Vertical Datum of 1929]

\begin{tabular}{|c|c|c|c|c|}
\hline Year & $\begin{array}{l}\text { Dis } \\
\text { in a } \\
\text { pargo } \\
\text { Fargo }\end{array}$ & $\begin{array}{l}\text { arge, } \\
\text { c feet } \\
\text { econd } \\
\text { Grand Forts }\end{array}$ & Comments & Primary neferences \\
\hline \multicolumn{5}{|c|}{ HISTORICAL FLOODS } \\
\hline 1776 & -- & -- & 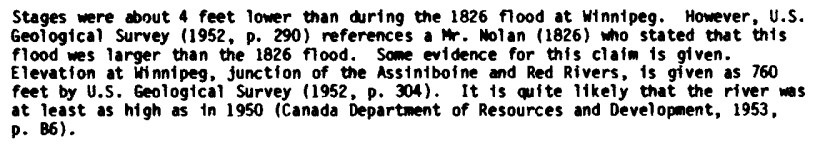 & Simons and $\mathrm{king}(1922, \mathrm{p} .52)$. \\
\hline 1790 & -- & -- & $\begin{array}{l}\text { Stages mere about } 4 \text { feet lower than during the } 1826 \text { flood at Winnipeg. Year in which } \\
\text { general overflow occurred (U.S. Geologtcal Survey, 1952, p. 304). }\end{array}$ & Simons and King $(1922$, p. 52$)$. \\
\hline 1809 & -- & -- & $\begin{array}{l}\text { Stages were obout } 4 \text { feet lower than during the } 1826 \text { flood at winnipeg. Year in which } \\
\text { general overflow occurred (U.S. Geological Survey, 1952, p. 304). }\end{array}$ & Simons and King $(1922, \mathrm{p} .52)$. \\
\hline 1815 & -- & -- & $\begin{array}{l}\text { Water mas remarkably high, overflowing its banks to a considerable distance at fort } \\
\text { Daer near Pewoina. }\end{array}$ & $\begin{array}{l}\text { Canada Department of Resources and } \\
\text { Development }(1953, \text { p. B7). }\end{array}$ \\
\hline 1824 & -- & $-\cdot$ & Listed as one of the worst floods known along the Red River along with 1825 and 1826. & Harrison and Blueale $(1980$, p. 14$)$. \\
\hline 1825 & -- & - & Listed as one of the worst floods known along the Red River along with 1824 and 1826 . & Harrison and Bluemle $(1980, p .14)$. \\
\hline 1826 & - & -- & 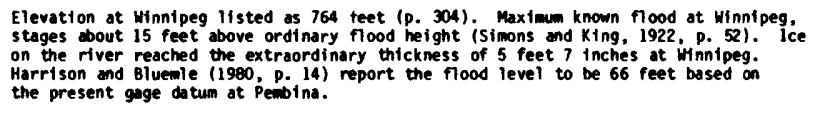 & $\begin{array}{l}\text { U.S. Geological Survey (1952, } \\
\text { p. } 290-303) \text {. }\end{array}$ \\
\hline 1851 & -- & $\cdots$ & & Harrison and Bluemle $(1980, p .14)$. \\
\hline 1852 & -- & - & $\begin{array}{l}\text { Elevation at Winnipeg listed as } 762 \text { feet (p. } 304 \text { ). Flood mas higher by } 1 \text { or more } \\
\text { feet than that of } 1882 \text { at and below Grand forks (Simons and King. 1922, p. } 52 \text { ). }\end{array}$ & $\begin{array}{l}\text { U.S. Geologtcal survey (1952, } \\
\text { p. } 303-304) \text {. }\end{array}$ \\
\hline 1853 & -- & -- & $\begin{array}{l}\text { No farming was cone in the Red River valley near Pentina due to the floods of this } \\
\text { year and the previous two years. }\end{array}$ & Harrison and Bluemle $(1980$, p. 14$)$. \\
\hline 1860 & 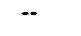 & $-\cdot$ & & Upham $(1895$, p. 56). \\
\hline 1861 & - & -- & $\begin{array}{l}\text { This flood may have exceeded the } 1897 \text { flood. Elevations are } 11 \text { sted for Grand forks } \\
\text { and winnipeg as } 830 \text { and } 762 \text { feet, respectively. }\end{array}$ & $\begin{array}{l}\text { U.S. Geological Survey }(1952 \text {, } \\
\text { p. 303-304). }\end{array}$ \\
\hline 1871 & -- & -- & This flood was exceeded during the 1897 flood. & U.S. Geological Survey $(1952$, p. 305$)$. \\
\hline \multicolumn{5}{|c|}{ RECORDED FLOOOS } \\
\hline 1882 & 20,000 & 68,000 & $\begin{array}{l}\text { The highest flood since } 1852 \text { at Winnipeg (S1mons and King, 1922, p. 52). Elevation } \\
\text { at Winnipeg isted as } 754 \text { feet (U.S. Geological Survey, 1952, p. 304) and at Grand } \\
\text { Forks IIsted as } 827.9 \text { feet } 10 \text {. O. Holmen, U.S. Geological Survey, written commun.. } \\
\text { 1980). }\end{array}$ & $\begin{array}{l}\text { Jarvis and others (1936, p. 233). } \\
\text { Discharges revised in recent years } \\
\text { due to avallabtlity of additional } \\
\text { hydraulic data. }\end{array}$ \\
\hline 1883 & - & 38,600 & & D. \\
\hline 1893 & -- & 53,300 & $\begin{array}{l}\text { Flood wes most serious between Grand Forks and the international boundary (Simons } \\
\text { and } \mathrm{K} \text { ing, } 1922, \mathrm{p} .52 \text { ). }\end{array}$ & Do. \\
\hline 1897 & 25,000 & 85,000 & 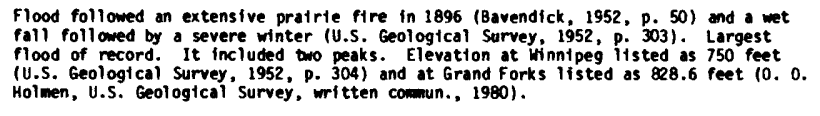 & $\infty$. \\
\hline 1904 & 5,220 & 33,000 & $\begin{array}{l}\text { Flood was most serious between Grand forks and the international boundary (5tmons } \\
\text { and king, } 1922, \text { p. } 52 \text { ). }\end{array}$ & $\infty$. \\
\hline 1907 & 7,000 & 30,400 & & $\infty$. \\
\hline 1916 & 7,740 & 29,000 & $\begin{array}{l}\text { Flood was most sertous in the vicinity of Fargo and upstream reaches (5imons and } \\
\mathrm{king}, 1922, \mathrm{p} .52) \text {. }\end{array}$ & D. \\
\hline 1920 & 6,200 & 30,300 & & Do. \\
\hline 1943 & 16,000 & 28,200 & & Recent records. \\
\hline 1947 & 9,300 & 35,000 & & Recent records. \\
\hline 1948 & 3,390 & 34,200 & & Recent records. \\
\hline 1950 & 7,800 & 54,000 & $\begin{array}{l}\text { Flood included tor peaks. The first peak was } 43,800 \text { cubic feet per second on } \\
\text { April } 25 \text { at Grand forks. The second peak at fargo was 6,520 cubic feet per second } \\
\text { on May } 12 \text {. }\end{array}$ & Recent records. \\
\hline 1952 & 16,300 & 23,900 & & Recent records. \\
\hline 1965 & 11,400 & 52,000 & & Recent records. \\
\hline 1966 & 10,700 & 55,000 & & Recent records. \\
\hline 1969 & 25,300 & 53,500 & & Recent records. \\
\hline 1972 & 7,250 & 31,400 & & Recent records. \\
\hline 1974 & 4,150 & 34,300 & & Recent records. \\
\hline 1975 & 13,200 & 42,800 & $\begin{array}{l}\text { Flood included to peaks. The ftrst peak as } 42,400 \text { cubic feet per second on } \\
\text { April } 22 \text { at Grand forks. The first peak was } 8,380 \text { cubic feet per second on April } 21 \\
\text { at Fargo. }\end{array}$ & Recent records. \\
\hline 1978 & 17,500 & 54,200 & & Recent records. \\
\hline 1979 & 17,300 & 82,000 & $\begin{array}{l}\text { Flood mes second largest after } 1897 \text { at Grand Forks. Elevation listed as } 828.5 \text { feet } \\
\text { at the Worthern Pactfic Rail road bridge site of original gage } 10 \text {. 0. Hoimen, U.S. } \\
\text { Geological Survey, witten commun., 1980). }\end{array}$ & Recent records. \\
\hline
\end{tabular}

- Recorded floods i1sted then discharge is greater than approximately 30,000 cubic feet per second and gage hel ght is greater than approximately 40 feet at Grand Forks or discharge greater than approxtmately 8,000 cubic feet per second and gage helght greater than opproxtmately 25 feet at Fargo.

This is a flood of approxinately a s-year recurrence in

14 Flood Response, Red River, N.Dak-Minn. 


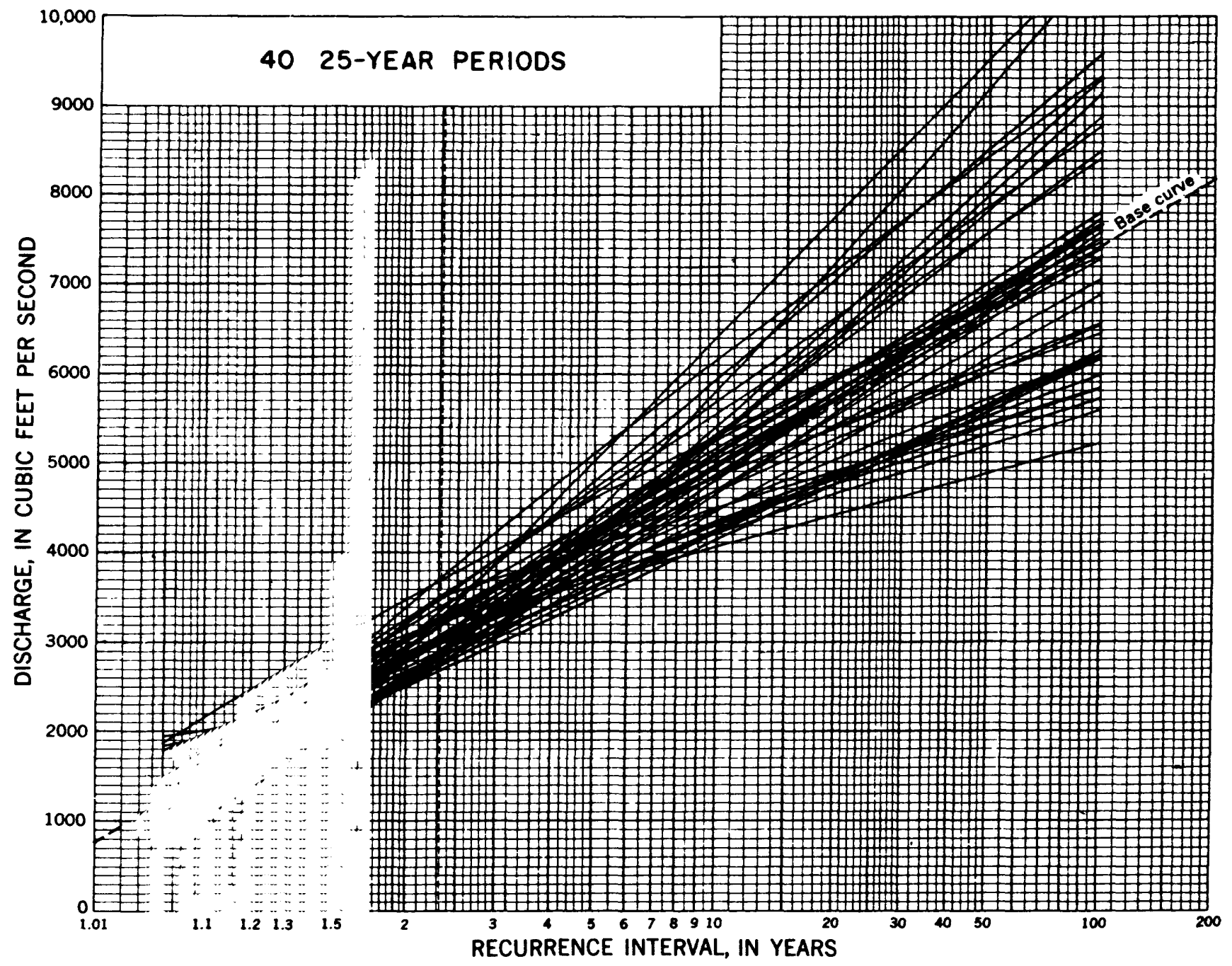

Figure 3. Variation to be expected in predicted flood frequency based on forty 25-year periods of record (Benson, 1960, p. 58).

The flood of 1897 is of interest because it is the largest flood recorded at Grand Forks. Simons and King $(1922$, p. 40) described the causes of the flood, including general climatological information.

\section{Flood-Control Works}

A number of flood-control works have been built in the Red River basin by the U.S. Army Corps of Engineers, U.S. Soil Conservation Service, States of Minnesota and North Dakota, and individual Minnesota and North Dakota watershed districts. A map showing the locations of existing and planned flood works in the Red River basin is given in figure 4 . These include reservoirs and channel improvements such as levees, channel snagging and straightening, and bypass channels.

Five principal reservoirs are now in operation (Lake Traverse, Orwell Lake, Lake Ashtabula, Homme Lake, and Red Lake) in the Red River of the North basin.
The broad, flat nature of the basin affords little possibility for the development of large-capacity reservoirs in locations where they would be effective. In the vicinity of the ancient beach ridges and in the upland areas, however, a number of reservoir sites with limited capacities might be developed. Based on the U.S. Army Corps of Engineers model studies of the Red River, the Red River Modeling Task Force (1981, p. 38) reported that, "The existing reservoirs in the headwaters of the Red River of the North have a negligible effect on flood peak and timing because of their limited storages. There are presently no structures being planned in either North Dakota or Minnesota that could significantly change peak flows or water levels at the international boundary."

Rannie (1980) discussed the flood works built to protect areas near Winnipeg, Manitoba. These works include two large diversion channels, storage reservoirs, and ring dikes around several communities. He stated 


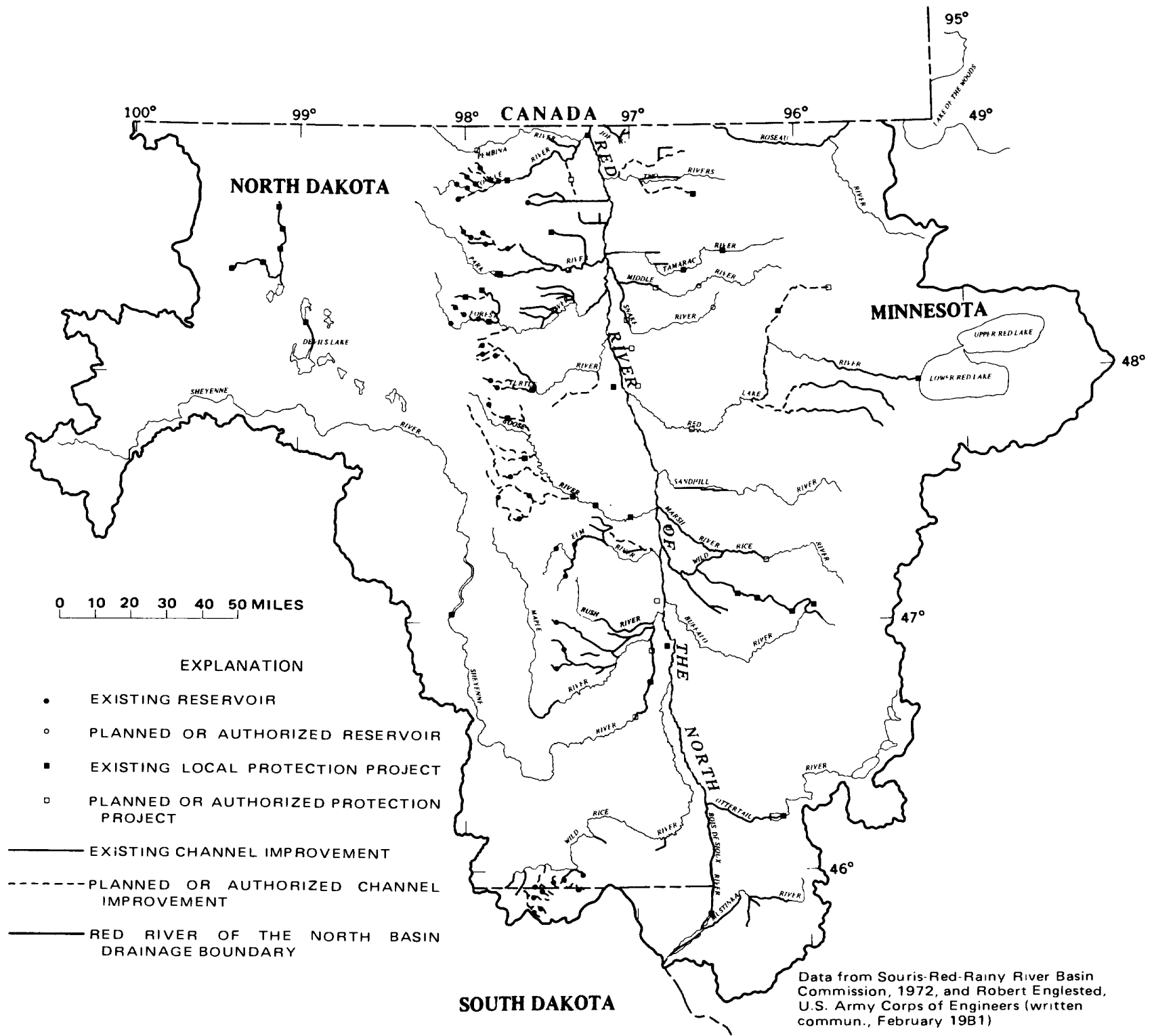

Figure 4. Existing and planned or authorized flood-control works in the Red River of the North basin.

that these measures constitute one of the most ambitious single-purpose flood-control projects in the world. In the 11 years following the completion of the Red River Floodway (one of the two diversion channels) in 1968, a series of peak flows on both the Red and Assiniboine Rivers has thoroughly justified the financial burden which the control system imposed on the comparatively small population of Manitoba.

\section{Purported Effects of Drainage, Channel Improvements, and Other Land-Use Changes}

The effects of drainage, channel improvements, and other land-use changes on the flooding problems of the Red River basin are difficult to identify because of the complexity of the hydrologic processes controlling floods, the expected natural variation in flooding with time, and the apparent regional increase in the water available to begin the runoff process in recent years. While numerous studies have been made of this topic, few reported studies have addressed all the considerations noted. To be identified as a basin-response change, the change needs to be shown to occur in spite of the above considerations. The controversy concerning the possible river-basin-responsechange problems has been described by numerous investigators.

Orlo A. Crosby and Quentin F. Paulson (U.S. Geological Survey, written commun., 1974, p. 2) in a waterresources investigation proposal to study hydrology of 
wetlands in the Devils Lake basin, stated that, for the Devils Lake basin, hydrologic misconceptions and myths have been adopted and circulated by various groups to suit the convenience of their arguments. In recent years, the problem has been compounded by recurring, above average runoff and by flooding of the basin due to large quantities of snowmelt and heavy spring rains. Controversies involve the effects of land drainage, changes in land use, urbanization, and farming practices in general. These same statements can be made concerning the rest of the Red River basin.

Campbell and Johnson (1975) noted a number of authors who gave conflicting opinions concerning the effects of agricultural drainage. They concluded that there is no simple answer to the question of the effect of agricultural drainage on flood flows. The Upper Mississippi River Basin Commission (1979, p. 12) noted several schools of thought, most of which are very speculative, regarding the effect surface drainage has had on flood stage heights and volumes on the Red River basin. Bluemle $(1980$, p. 1) reported that the effects of drainage ditches are not simple or well understood. Simons and King (1922, p. 19) stated that it is exceedingly difficult, if not impossible, to measure the effect of the various factors upon the runoff; and in the absence of measurements from a given watershed, the determination of the probable rate of runoff becomes a complex problem.

Noting the natural variation in flood flows, the U.S. Army Corps of Engineers (1977, p. 17) stated that natural factors such as changes in weather cycles might be far more significant in influencing existing hydrology than any manmade event or improvement. In 1922, Simons and King (p. 49) suggested that there is nothing to indicate that the rate or volume of runoff is undergoing any permanent change in the Red River valley. Rather, it seems probable that future runoff during any long-term period would be subject to seasonal or periodic fluctuations as great as any that have occurred in the past. Based on statements made by Simons and King concerning both past and future floods, there is reason to believe that the periodic fluctuations are actually much greater than they realized.

Linsley and Franzini (1972, p. 626) pointed out that since about 1930 there has been a rapid increase in the use of water-conservation measures in agriculture. Contour plowing and terracing are used to retard surface runoff and to promote infiltration of water into the soil. Farm ponds retain the flow of small creeks for irrigation and stock water. In addition, cover crops are used in fields to avoid bare, fallow ground during the nongrowing season. There is no argument about the value of these measures for the reduction of soil erosion and the preservation of soil moisture, but there is debate as to their value from the viewpoint of flood mitigation. Linsley and Franzini further stated that water- and soil-conservation methods are useful in reducing flood flows in small streams but are not very beneficial in the protection of areas along major streams or in the control of unusually large floods.

Wilcock (1979, p. 146) studied the results of land drainage in northern Ireland. He noted that conflicting claims are made about the effects of arterial drainage on runoff. Some claim that the increased capacity of a postdrainage arterial river and a lowered water table combine to reduce ground-water flow below predrainage levels and increase catchment response to heavy rainfall, resulting in a "flashier" stream. Others claim that the increased storage made available by a lower water table dampens high flows and augments low flows. These arguments are also applicable to small basins in the Red River basin. However, determining the effects downstream on the Red River main stem requires that the water-routing processes also need to be considered.

The Souris-Red-Rainy River Basin Commission (1972b, p. E-31) described agricultural drainage in the Red River basin as follows: Major drainage outlets are large open drains usually located in the lowest adjoining areas and on section lines or on quarter-section lines. They are constructed to maximize on-farm drainage benefits and to safely convey floodwaters. Because of their size, their banks are commonly grassed and nonfarmable. In the large, broad lake-plain areas, they generally flow into rivers or natural coulees that flow into rivers. Drainage is agriculturally advantageous if it can help prevent the complete saturation of the soil. Ditches can assist by removing the excess from the surface before it passes to the lower soil. This process supplies the lower soil with as much moisture as is necessary and at the same time removes part of the surface surplus.

Application of on-farm drainage for soils with minor wetness conditions is generally accomplished either by random drainage for small shallow areas or by drainage ditches spaced at intervals. These on-farm drainage ditches are normally flat-bottom ditches with flat side slopes for ease of farming. In the larger lake-plain areas, drainage is accomplished by spacing ditches at predesigned intervals, by random ditching, or by a combination of the two. Where the land is extremely flat, as in the Red River basin, some land grading or smoothing is being used. This is accomplished by using large earthmoving machines for the rough grading and land planes for the final grading. The problem of ponding in areas of low relief is eliminated by land smoothing.

\section{Water-Routing Studies}

One possible effect of agricultural drainage is to increase flood peaks by removing water faster than natural conditions and by eliminating potential storage from 
small watersheds. However, drainage channels may reduce flood peaks by draining away heavy fall rains that would otherwise leave the soil saturated through the winter. No matter how a runoff event is affected on the small basin, the effect of the runoff downstream is dependent on the water-routing processes given in table 7. These processes control the timing of the peaks throughout the basin and ultimately the size of the peak and the shape of the hydrograph downstream on the Red River main stem.

A number of studies have been done that attempted to include the effects of the water-routing processes in the analyses. The approach is reasonable hydrologically. The general procedure is as follows:

1. Make an estimate of the effect of drainage or other land-use changes on small subbasins within the basin, based on one of the two concepts noted by Wilcock earlier in this report. Estimate both predrainage and postdrainage outflow hydrographs for each subbasin for all snowmelt-runoff events.

2. Develop a flow-routing model of the drainage system connecting the subbasins.

3. Couple the flow-routing model with the estimated subbasin-outflow hydrographs.

4. Calibrate the model on predrainage conditions or the drainage condition for which there is a streamflow record.

5. Apply the postdrainage adjustment to the subbasinoutflow hydrographs.

6. Rerun the model for the entire period of record to determine the effect of drainage on historical flood flows.

Some investigators have used an estimated increase in drainage area with magnitude of runoff event to estimate runoff hydrographs. Mahood $(1977$, p. 13) defined three types of drainage areas:

1. Dry (effective) drainage area - the area that might be expected to contribute to streamflow in an average year. This excludes marshes, sloughs, and other natural or artificial storage areas.

2. Wet drainage area-the area that might be expected to contribute to large floods; includes any part of the drainage basin connected to the main stream by an indication of a channel.

3. Gross drainage area - the area that might be expected to contribute to streamflow under extremely wet conditions.

Banga (1978, p. 8) assumed that contributing drainage areas increase linearly with the probability of the corresponding flood event between the 2-year flood event and some large flood event such as the 1,000-year flood where it is assumed that the gross drainage area contributes. Draper $(1973$, p. 37$)$ used a regression analysis to relate the density of drainage ditches to flood peaks in the
Roseau River basin in his application of the waterrouting approach.

The water-routing approach has been used by Mahood (1977), Banga (1978), Pentland (1980), and Draper (1973). Mahood found that present drainage development in the upper Souris River basin significantly increases the volume of inflow to the marsh studied. A relatively large increase in runoff volume for a 2-year flood event was predicted. However, a relatively small increase in volume for a larger flood event would be expected. Peak inflows into the marsh increase significantly under the present partly drained conditions as compared to natural conditions. However, further development will not cause much increase in peak flow.

Banga (1978) found that in Saskatchewan, Canada the Moose Jaw River drainage projects could increase flood peaks ranging from 13 percent, plus or minus 5 percent, for the 2-year flood event and 2.5 percent, plus or minus 5 percent, for the 500-year flood event. He also concluded that the effects of agricultural drainage on flood potential are reduced with distance downstream from the drainage works.

Pentland (1980) did further work on the Moose Jaw River. He developed a predrainage and postdrainage effective drainage area and frequency relationship that shows the same drainage area for predrainage and postdrainage for a 1,000-year flood and a diverging drainage area for the smaller return period floods. An estimate of postdrainage runoff is made by computing the ratio of postdrainage effective area divided by predrainage effective area and multiplying that by the predrainage runoff. This is a very simplified approach that may be reasonable for runoff volumes. A postdrainage volume-frequency curve can then be drawn with a number of years of record of predrainage volumes. Then the ratio method can be applied to estimate the new runoff volume and a new runoff-volume-frequency curve can be drawn.

Potential errors in this method include the following: (1) The effective drainage area for a given event (for example, a 2-year flood) would require a great deal of subjective judgment in map or aerial photo interpretation; (2) the method assumes uniform runoff yield for the effective drainage area, which actually varies, diminishing to zero at the effective drainage boundary; and (3) the method asusmes that the water moving through the ground-water system either is not significant or will not be changed by surface-drainage developments. This last error may have a very significant effect, especially for the first few years following the drainage development during which the water-table aquifer may drain to match the lower minimum drainage level that the deeper channel provides.

The results of Pentland's study showed that in extreme floods such as the 100-year and 500-year events, 
the increase due to full drainage development would be about 2.8 percent and 1.4 percent, respectively, for flood volumes. This decrease in percentage change is due mainly to the variability of effective drainage area with the magnitude of flood. The peak flows would increase 13.1 percent and 2 percent for the 2-year and 500-year flood events.

Draper (1973) found that the greater the density of drainage ditches in the subbasins of the Roseau River basin the smaller the runoff peaks. He suggested a number of explanations of this. The first suggestion is that because the bottoms of the drainage ditches are several feet below the ground surface, a general lowering of the water table occurs in parts of the basin during low-flow periods. The lower water table prior to flood periods would allow more of the spring runoff to enter ground-water storage. The result would be a lower surface-water runoff rate and lower flood peaks. The second is that many of the overland ditches follow roads, which are likely to have a negative effect on floods due to temporary retention of runoff and disruption of natural runoff patterns. The third suggestion is that in small local areas ditches may actually increase local runoff peaks. However, this may flatten the hydrograph for larger areas by enabling local inflows to enter the lower reaches of the river sooner, and thereby, be less coincident with the flood crest moving down the river. The fourth suggestion is that some ditches in flat, swampy areas may do little more than provide additional storage capacities, particularly with snow and ice conditions inhibiting runoff in spring breakup periods.

Draper concluded that the higher the density of ditches the lower the flood peak in the Roseau River basin. The amount of variation of the points about the regression lines explained by the ditches term in the regression is not due to chance alone.

Draper (1973, p. 53) concluded that the network of overland drainage ditches constructed in the United States part of the basin prior to 1920 appears to have reduced flood peaks in the Roseau River. In Draper's opinion, the most prominent theory in support of these findings is that the ditches have produced, on the average, a lower ground-water level in late summer and winter. Consequently, there has been more recharge capability during spring flood periods. The reduction in flood peaks is related to the additional amount of water being accepted in ground-water storage.

The effects of early revisions in the Roseau River main channel were also quantitatively defined with Draper's water-routing model. Analysis shows that if the original channel conditions had existed before the 1948, 1950 , and 1966 floods, the peak discharges would have been 10 to 20 percent lower and the time of peak would have been 5 to 10 days later. The previous channel was longer with a lower gradient and was more restrictive to flow, creating slightly more storage retention than the present channel. This study indicates that changes in channel size and gradient are more likely to affect the flood peaks of a basin than the density of drainage ditches upstream. This points out the importance of the waterrouting processes shown in table 7 .

\section{Regression-Analysis Studies}

Regression analyses have been done to attempt to evaluate the effect of drainage and land-use changes on flood flows. One of two approaches can be employed. One approach uses records for several basins to relate basin characteristics to peak flows; another uses data from one basin to compare parameters that characterize the processes controlling flood peaks to recorded floods.

In the first approach basins of varying land use with long-term streamflow records are used in an attempt to relate basin characteristics to peak flows. Draper (1973) used this approach for subbasins of the Roseau River basin. Moore and Larson (1979) also used this approach, and analyzed data from 73 streamflow-gaging stations on small watersheds in the prairie pothole regions of Minnesota, North Dakota, South Dakota, and Iowa. Regression analyses were made in an attempt to correlate peak discharges with watershed characteristics. The authors concluded that statistical analysis of historical data is problematic and, at least for small watersheds, the available data do not limit the variables sufficiently to permit the determination of the effect of drainage on peak flows by statistical analysis.

A number of studies reference a report by Conger (1971) when citing the significance of depressional storages on flood peaks. He studied several basin characteristics in order to develop regression equations for estimating the magnitude and frequency of floods in Wisconsin. The parameters found to be important are drainage area, main channel slope, lake and marsh area, and some areal factors. The point usually noted is that the lake and marsh area was found to be significant. However, in Conger's (1971) study the normally noncontributing areas such as depressional-storage areas were not included; only lake and marsh areas that drain directly were included. The depressional-storage areas similar to those found in the Red River basin were counted as noncontributing and were not included in the total drainge area (D.H. Conger, U.S. Geological Survey, oral commun., February 10,1981). The lake and marshes included in the study most likely interrupted the stream drainage directly or were connected by tributaries. This instream storage has a large attenuating effect on flood peaks. Therefore, the importance of lakes and marshes shown in this study cannot be assumed to be equally applicable to the effect 
of depressional-storage areas in the Red River basin. Instead, because of the large variation in hydrologic characteristics of the depressional storages in the basin, the effects of the storages on flood peaks is not well understood and cannot easily be generalized.

A second approach is to use a number of years of record for one basin and attempt to relate parameters that characterize the processes cont rolling flood peaks to recorded flood peaks. However, a difficulty with this approach is that the complexity of the runoff processes and the natural variability in flood flows make it difficult to adequately characterize all of the important processes controlling flood peaks. If a very long period of record and detailed hydrologic parameters are not included in the analysis, any variation in peak flows may be attributed to suspected basin changes, such as drainage, when the variation may actually be due primarily to the natural variation in flood flows.

This difficulty is particularly apparent on the Red River because of the large variation in flood flows with time. The recorded floods between 1900 and 1950 were all of relatively small magnitude, while the floods since 1950 have been relatively large. The large increases in drained acreage occurred during a 10 - to 20 -year period surrounding 1950 . However, recorded and historical floods in the late 1800 's were also very large, and correspond to those experienced since 1950. Because the data, other than flow data, required for a regression analysis are often not available for the late 1800's, the regression analysis is usually run using only more recent records. Therefore, the resulting regression equations include only the small peaks in the predrainage period, and the effect of increased drainage correlates well with the increased flood flows since 1950.

Any two increasing factors will show a significant correlation. However, this does not prove that the two factors are related. If the large floods of the late 1800's were included in the analysis, the results would not be as significant because the analysis would include the effect of the natural variation in flood flows with time over a longer period.

Dale L. Frink (written commun., 1980), in a North Dakota State Water Commission study of climatic conditions and Red River flooding at Grand Forks, N. Dak., used the second approach on the Red River. He found that climatic conditions account for the greatest proportion of the variation in volumes and in peak discharges. There was little increase in the volume of flow from 1904 to 1979 that cannot be accounted for by climatic conditions. However, while the results of the study indicate that climatic conditions primarily account for the magnitude of Red River floods, other factors have apparently had an effect on the increased magnitude of the flood peaks and volumes.
These other factors may be land-use changes; however, it is also likely that water-availability processes or other processes may control the magnitude of floods that were missed. Because the Red River has experienced some large floods in the last 30 years, Frink's analysis would be expected to yield this result if controlling factors were missed.

Hammen (1980) used a similar approach. His analysis included the period 1950-79. Because the greatest percentage of drainage had already occurred by the middle 1950's, his analysis did not include any periods with little or no drainage. He concluded that almost all of the variation of flood flows could be accounted for by climatic factors.

\section{Watershed-Model-Analysis Studies}

The Upper Mississippi River Basin Commission (1979), the U.S. Army Corps of Engineers (1979, 1980a, and 1980b), and Leitch $(1980$, p. 9) have recommended that watershed-runoff computer models be used to determine the effects of drainage and other land-use changes in the Red River basin. Such models have been developed extensively since the 1960 's. The basic concept in the use of these models is mathematical representation of all the processes listed in table 7. Because of the large number of processes involved, the models are generally very complex. In their development, certain assumptions are made in order to simplify them so that they can be programed and be more readily understood. Thus, in their application, the modeler needs to make sure that the assumptions made by the model fit his basin and application.

To determine the effects of a land-use change, the models need to be able to explicitly represent all of the important processes controlling the rate of runoff in the basin. The modeler needs to be able to quantify the effects of the land-use change so that this change can be represented in the model. If this cannot be done, the modeler is simply adjusting the many parameters in the model to make it reproduce the measured results. It is not known whether or not the model represents the basin. Then, in an attempt to represent a land-use change, the correct adjustments must be made to the proper parameters to represent the change. If the controlling processes are not understood or not explicitly represented in the model, the adjustment made to represent the effect of land-use changes is only a guess. It will probably only give results already expected by the modeler.

The HSP model developed for the U.S. Environmental Protection Agency has been applied to depressional-storage basins such as the Red River basin. There are a number of assumptions in the HSP model that may not adequately represent the processes controlling runoff 
in a depressional-storage area. This is to be expected because of the uniqueness of the subbasins in the Red River basin. Significant alterations would be required in the model representation of the water-availability (snowmelt), water-excess (infiltration), and water-routing (depressional storages and channel flow) processes listed in table 7.

Moore and Larson (1979) have attempted to develop a model that more adequately represents the processes controlling runoff in a depressional-storage region. They note that their results are dependent on the validity and accuracy of their model. They were unable to apply an adequate calibration and verification process to their model. However, they draw the following conclusions regarding the effects of drainage on small watersheds: There are significant increases in annual runoff, storm volume, and peak discharges, and the effect of main channel improvement on peak flow was more significant than the effect of draining individual depressions.

While hydrologic models are complex and their application to depressional-storage watersheds is questionable, the use of hydraulic models and carefully developed and tested hydrologic models to evaluate the Red River flooding problems may be useful. Flow-routing models can be used to account for the water-routing processes in the basin. The Souris-Red-Rainy River Basin Commission (1972b, p. D-142) recommended this approach. The Red River Modeling Task Force (1981) described the development of HEC-2, HEC-3, and HEC-5 models of the Red River and an expectedannual-damage program. These models have been applied by the U.S. Army Corps of Engineers to the Red River. The HEC-2 model develops water-surface profiles using the standard-step step-backwater method for steady, gradually varied streamflows. The HEC-3 model is a water-balance model which accounts for hydrology (such as inflows or evaporation), reservoir operations, powerplants, and diversions to meet water requirements at control points. The potential water requirements are listed as water supply, navigation, recreation, low-flow augmentation, and hydroelectric power. The model was applied to the Red River to evaluate existing and proposed water-storage projects in the basin.

\section{Miscellaneous Studies}

A number of studies have noted miscellaneous conclusions that are of interest. Based on water-balance and other studies done in Ireland, Wilcock (1979, p. 147) found that the effects of drainage appear to be threefold: (1) A rapid withdrawal of water from ground-water storage over an 18-month period, followed by a more extended period of replenishment lasting for 4 to 12 years if the channel is not maintained; (2) a reduction in the magni- tude and frequency of the highest discharges; and (3) an immediate but not long-sustained increase in groundwater flow to the stream.

The decrease in tall prairie grasses due to land-use changes including the extensive practice of summer fallowing in the Red River basin may increase exposure, thereby melting the snow more quickly. Paul and Verry (1980) concluded that forest clearcutting caused a significant increase in peak flows in Minnesota. As a forested area is cleared, the increased exposure to the snowmelt factors listed in table 7 increases the melt rate. However, while this increases the rate of water availability, both the water-excess and the water-routing processes must occur before the water made available due to snowmelt becomes a flood event.

Simons and King (1922, p. 41) stated that artificial drainage may increase the rate of runoff by increasing the number of outlets and thereby shortening the time period during which runoff occurs. However, the decrease in runoff due to increased absorption by the drained soil may more than compensate for the extra outlets.

A number of investigators have studied the correlation between drainage density and streamflow. Most of these investigators have attempted to relate the natural development of drainage density to flood flows and to low flows. The concept of drainage density was introduced by Horton in 1932 and is defined as (Strahler, 1964, p. 4-52):

$$
D=\frac{N=1}{A} L_{\mathrm{i}}
$$

where

$D=$ drainage density in miles per square mile,

$L_{\mathrm{i}}=$ length of individual channel segments in miles,

$N=$ number of channel segments,

and

$A=$ total basin drainage area.

$D$ can be thought of as an expression of the spacing of channels. Dingman (1978) stated that instead of $L$, a better parameter may be the effective channel segment length, which is equal to the valley length. Carlston (1963, p. C6), for example, developed a relationship for the mean annual flood as follows:

$$
Q_{2.33}=1.3 D^{2},
$$

where $Q_{2.33}=$ mean annual peak discharge.

This indicates that as the naturally developed drainage density increases the mean annual flood increases. 
Because the relationships were developed for natural conditions, their direct application to the Red River drainage problem is questionable. However, they are mentioned here because of their potential use in further studies. The development of additional drainage ditches in the Red River basin could be quantified by determining the resulting increase in drainage density.

\section{History of Basin Changes}

Before the first immigration of white men to the Red River basin, a tall grass and mixed grass prairie dominated the plains while deciduous and mixed forests developed in the eastern uplands and the stream valleys. The only extensively forested areas were in the eastern extremes of the basin. Upham (1895, pl. XXXV111) mapped the wooded areas. The U.S. Army Corps of Engineers $(1978$, p. 35$)$ reported that the tall grass prairie consisted of blue-stem switch grass, Indian grass, and wild rye. These grasses often reached a height of 4 to 5 feet, and the big blue-stem grass often reached even greater heights.

Upham (1895, p. 584-587) described numerous swamp or marsh areas within the Red River basin in Manitoba, the Red River valley, and east of the valley. He stated that extensive swamps near Red, Mud, and Thief Lakes, Lake of the Woods, and Roseau Lake made the area northeast of Red Lake virtually impassable except in the winter (at the time of his writing). $\mathrm{He}$ described marshes varying in extent from a few hundred acres to $50 \mathrm{mi}^{2}$ in the Red River valley as follows (p. 584-585).

An enumeration of the most noteworthy of these boggy, partially inundated areas in Minnesota includes the marsh, 6 miles in diameter, occupying the greater part of Winchester, Norman County, in crossing which the south branch of the Wild Rice River becomes diffused and lost, until it is gathered again on the western border of the marsh by the union of the waters of many rills, brooklets, and springs; the marshy grounds in Anthony and Halstad townships, also in Norman County, lying on each side of the Marsh River; the great swamp in southwestern Polk County, in which the Sand Hill River is lost for about 9 miles, being again formed by many brooks that flow from the western edge of the swamp along a distance of 5 miles from south to north; the Snake River marsh in Sandsville, on the north line of Polk County; the marsh in Bloomer, Parker, and Big Woods, Marshall County, in which the Middle River is lost for 5 miles next above its junction with the Snake River; and the large swamp in the northern edge of this county, extending also into Kittson
County, formed by the outspread waters of the Tamarack River, which is thus lost across a distance of 8 miles.

Marshes in North Dakota are described as being much smaller. These include the marsh 2 to $3 \mathrm{mi}$ across in Cass County in which the Rush River is lost and marshes near Salt Lake.

Upham (1895, p. 612-613) stated that the first immigration of white men to colonize the fertile basin of the Red River of the North, bringing the agriculture of Europe, was in the years 1812 to 1816 . Under Lord Selkirk's supervision, the early pioneers of the Selkirk settlements, coming by the way of Hudson Bay and York Factory, reached Manitoba and established their homes along the river from the vicinity of Winnipeg to Pembina.

A period of 50 to 60 years after the founding of the Selkirk colony, the margin of advancing wave of immigration in the United States reached the Red River valley. In a few places on the Red, Wild Rice (North Dakota), and Sheyenne Rivers, small bands of immigrant farmers had begun the settlement of this rich agricultural area a few years before the building of railroads across it. However, the main tide of immigration came after the railroads had provided a means of sending the staple product of the country, wheat, to the markets of St. Paul, Minneapolis, and Duluth. The Northern Pacific Railroad was built from Duluth to Moorhead and Fargo during the years 1870 to 1872 , and the next year it was extended to Bismarck. Within the next 3 years, a line of the Great Northern Railway (then the St. Paul and Pacific) was built to Breckenridge and another line to Crookston and St. Vincent. From 1875 to 1885 , the settlement of the Red River valley and of a large contiguous area of North Dakota and South Dakota went forward very rapidly. Nearly all the land in this valley was taken up during the 10 years by homestead and preemption claims from the Government and by land purchase from the railroad corporations that had received land grants.

Simons and King (1922, p. 1-2) reported that a comprehensive drainage program was essential for the proper development of agriculture in the valley of the Red River of the North. This was recognized soon after farming began to be extensively practiced in the valley, about 1870 . The initial effort toward a comprehensive drainage plan was made at a convention at Crookston, Minn., in 1886, when arrangements were made to prepare plans for draining six Minnesota counties bordering on the Red River. Upham (1895, p. 585) reported that a survey for a plan of drainage for the eastern side of the Red River valley in Minnesota was made in 1886 by a Mr. C.G. Elliot. The area that was supposed to be benefited by the drainage was 808,600 acres. U pham did not report how much of the drainage was actually constructed. In 1900 , as a result of the disastrous 1897 flood in the valley, 
a tristate drainage association was formed among North Dakota, South Dakota, and Minnesota property owners and other parties interested in the welfare of the valley. And, in 1906, an international drainage conference was held at Grand Forks, N. Dak., which was attended by delegates named by the governors of the three states in which the valley is situated and by delegates for Manitoba, Canada. Much time and money was expended on various plans for obtaining relief from floods and poor drainage conditions. Later, in 1918, interested landowners raised a fund of $\$ 2,300$ to contribute to a drainage study. The fund was raised largely through the efforts of $\mathbf{M r}$. Herbert A. Hard of the North Dakota Flood Control Commission.

As a result of his study, Hard (1921, p. 63) reported that many millions of dollars had already been spent in Minnesota on open ditches where ditching began in 1890 . Since 1900, when the work was started in North Dakota, several more millions had been spent. Since 1910, construction of canals and ditches had gone on at a rapid rate making large areas tillable that were formerly waterlogged. In the Mustinka watershed in Traverse County, as in many other localities, most of the land was drained by open ditches $1 \mathrm{mi}$ apart.

Drache $(1970$, p. 150-160) reported that the flatness of the valley caused early settlers to be apprehensive of potential flooding. Therefore, they carefully avoided settling in the low areas. One of the best examples of this trend is found in the history of the Felton region in northeastern Clay County. It was initially opened in 1880 , but was not settled until the state drainage canal was completed in 1895 . The only crop that could be successfully harvested there in the early years was native prairie hay, but even haying was not extensive until after the canal had been built.

The drainage problem was most severe in the Manitoba part of the valley, and by 1879 the provincial assembly had advanced funds for drainage there. Each year the project was expanded, and in 1920 more than $1,342 \mathrm{mi}$ of ditches had been dug, draining 1,103,760 acres and enabling 350,000 acres to be tilled for the first time. Progress was slow at first, but by 1908, 50 machines were at work digging ditches in Minnesota. In the North Dakota part of the valley, the drainage program advanced much more slowly. The agricultural agencies eventually did initiate drainage projects in Cass, Traill, Grand Forks, and Walsh Counties.

Stewart $(1907$, p. 7) reported that the lack of comprehensive plans for drainage in the valley parts of the counties in North Dakota bordering the Red River of the North often seriously retarded necessary drainage of farmlands in that section. This fact was brought to the attention of the delegates to the Second State Irrigation Convention held at Bismarck, N. Dak., in January 1905.
A resolution was passed by that body requesting that the office of Experiment Stations of the United States Department of Agriculture render assistance by making a survey, plans, and reports for guidance of landowners and district engineers in constructing drainage ditches.

Early attempts were made at artificial drainage (Stewart, 1907, p. 14). With few exceptions, the ditches constructed were made along the public highways by means of road machines, without reference to regular grades, adequate sizing, or final outlets. They were not satisfactory because they were too small to serve the areas to be drained. They frequently overflowed and spread water over low, level farmland. Attempts had been made to increase the carrying capacities of some of the ditches by building small levees on the sides, but no permanent benefits had been derived from the practice. Ignorance in regard to surface slope led to faulty location of many drains.

In the first quarter of this century, very large sums of money were spent on drainage ditches in the valley, but, for the most part, the ditches were in a state of neglect during the 15 to 20 years prior to 1942. Every county in the valley on both sides of the river had systems of big drainage ditches built largely in the first 25 years of this century. In North Dakota, Cass County had $177 \mathrm{mi}$ of these old drains, Richland County had $104 \mathrm{mi}$, Ransom County $16 \mathrm{mi}$, Sargent County $75 \mathrm{mi}$, and Traill County $116 \mathrm{mi}$. There were extensive systems in Minnesota in Wilkin, Clay, and Norman Counties in the southern end of the valley; the northern end of the valley also was well supplied with these old drains on both sides of the river (Wilde, 1945, p. 2 and 5). The Upper Mississippi River Basin Commission (1979, p. 1) estimated that since the early 1900's nearly 4.5 million acres of agricultural land have been drained in the Red River valley and major tributary basins.

The amount of land that has benefited from drainage and the number of miles of drains that have been built are listed by county for North Dakota and Minnesota in the Agricultural Census. These data were tabulated for the counties in the Red River basin and totaled. The results, however, do not compare to the history of drainage efforts in the basin. There is an indication of some inconsistencies in the data-collection methods, which limit the usefulness of the data. The results, therefore, are not included here.

Augustadt (1955, p. 569-576) described the development of the major drainage system in the Red River basin. Following Stewart's (1907) plans, $697 \mathrm{mi}$ of the major drains had been constructed by 1944 . Work was slowed during World War II, but by 1955, 3,176 mi of major drains had been constructed. Also, $963 \mathrm{mi}$ of the 2,000 mi of mains and laterals estimated to be needed were constructed. Individual farm drainage amounted to 
$2,213 \mathrm{mi}$ of drains. This was about half of what was estimated to be needed.

According to the Souris-Red-Rainy River Basin Commission (1972b, p. E-40), $46,929 \mathrm{mi}$ of on-farm drainage and 3,073 mi of major outlets existed in 1967. The report also provides data on the number of acres benefiting by drainage in the Red River basin. These data are listed in table 9. The Souris-Red-Rainy River Basin

Table 9. Acres benefiting from drainage in 1967

\begin{tabular}{lcrr}
\hline & Major outlets & \multicolumn{1}{c}{$\begin{array}{c}\text { On-farm } \\
\text { acres }\end{array}$} & \multicolumn{1}{c}{ Total } \\
\hline Cropland & 549,299 & $2,514,800$ & $3,064,099$ \\
Pasture and range & 65,301 & 298,962 & 364,263 \\
Forest land_/ & 113,701 & 520,546 & 634,247 \\
Other agricultural land & 39,949 & 182,896 & 222,845 \\
\multicolumn{1}{c}{ Total } & 768,250 & $3,157,204$ & $4,285,454$ \\
\hline
\end{tabular}

1/Forest area benefited by adjacent agricuitural drainage or in process of being converted to agricultural lands.

Commission (1972b, p. E-56) related miles of drains to acres of land receiving surface-drainage benefits as follows: When drainage mains, drainage field ditches, and floodway practices are installed, it can be expected that $125 \mathrm{acres} / \mathrm{mi}$ of ditch would be benefited within the Red River basin. Areas vary in size for each mile of drainage ditch due to the influence of soils, topography, and regional slope.

The U.S. Army Corps of Engineers (1978, p. 97) stated that drainage of wetlands in the Red River basin has recently become a concern to downstream landowners, environmentalists, and the States of Minnesota and North Dakota. Concern involves the loss of valuable wildlife habitat and possible increase in downstream flood problems. The Corps concluded that the drainage trend is not expected to continue for a number of reasons: (1) most small, shallow wetland areas in the headwater part of the basin already have been drained; (2) because the various interest groups are placing greater emphasis on preserving wetlands, it is reasonable to assume that existing water-management boards and watershed districts will exercise responsibility for the remaining wetland areas by stopping drainage or by modifying the extent of drainage; and (3) because of concern by many interests in the Devils Lake subbasin, a plan has been developed for orderly water and related resource conservation. A similar plan may be developed in the rest of the Red River basin if drainage continues.

It has been noted that there was a significant amount of drainage development in the early 1900's and then again in the 1940's and 1950's. It is estimated that the vast majority of the land drained was drained following World War II. Other land-use changes such as tillage practices, urbanization, and road construction have undergone significant changes since the early 1900's.

\section{The Analysis Problem Perspective}

The problem is to document any significant change in flood response of the Red River basin. In other words, the following question is being asked: For the same wateravailability conditions (see table 7), can it be documented whether the flood response of the basin has changed due to land-use changes? Many studies have been done in an attempt to make this determination. However, most of the studies failed to recognize the hydrologic complexity, the historical variability, or the regional trends in flood flows. Without a comprehensive perspective of the analysis problem, a hydrologically sound analysis of response changes cannot be conducted.

This perspective does not indicate that there has been no response change. Instead, it shows that any response change that may have occurred needs to be documented in spite of the hydrologic complexity, historical variability, or regional trends in flood flows on the Red River main stem. The analysis problem perspective has been emphasized in this report because, based on the numerous studies which have been reviewed, a need for this perspective is apparent. This perspective has been organized into three concepts - the perspective hydrologically, historically, and regionally. This perspective provides a basis for further studies of the response-change problem and for evaluating the adequacy of previous studies.

\section{Hydrologically}

The analysis problem perspective, hydrologically, is that the processes and factors affecting these processes that control flooding in the Red River basin (table 7) are complex. The processes are numerous and each one is difficult to characterize with any simple climatologic, topographic, or hydrologic parameter. This makes it difficult to analyze the effect of any changes in just one factor or process involved in the overall flooding problem.

For example, if a change occurs in a small basin, such as the construction of a surface-drainage system, a number of processes in table 7 are affected. This would modify the water-excess processes-infiltration and pocket storage-and the water-routing processes-overland flow, depressional storages, ground-water flow, and interflow. The changes in runoff due to the effect of these modifications are, as yet, subject to the remaining water-excess and water-routing processes before they produce any 
significant change in response with respect to floods on the Red River main stem. It is difficult to quantify the effects of all of these processes.

\section{Historically}

The analysis problem perspective, historically, is that large variations in flood flows with time are expected (table 8). Floods on the Red River main stem are highly variable. The historical floods of 1826,1852 , and 1861 were all reported to be very large floods, and the flood of 1897 was larger than any other flood that has occurred since 1900 at Grand Forks. The large floods in the late 1800 's that compare to those since 1950 indicate that the natural variation in flood flows with time may be so great that a study of flood-response changes on the Red River may need to include data for floods of the late 1800 's to provide an adequate evaluation of the period prior to significant land-use changes.

While a number of large floods have occurred in the last 30 years, it is common when a long-term flood record is examined to find 20- to 30-year periods when flooding seems to have increased or decreased. The history of flooding on the Red River may not be different from the variation expected.

\section{Regionally}

The analysis problem perspective, regionally, is that changes in flood response of the Red River must be different from the rivers in basins that have not experienced extensive land-use changes. Adjacent river basins may have also experienced an increase in flooding but have not experienced extensive land-use changes. A regionwide pattern variation in flood frequency has been noted. This indicates that the increase in flooding in recent years is due, at least in part, to a regionwide variation in the water-availability processes listed in table 7.

\section{PART 2-DATA REVIEW}

A review of the data used in this study is provided to indicate where it can be obtained and to make it readily available for future studies. The following review of streamflow and climatological data is provided in tabular and graphical form because of the large amount of data.

\section{Streamflow Data}

Streamflow data are collected on the Red River and its tributaries in North Dakota and Minnesota by the
U.S. Geological Survey. A listing of the streamflow stations and their corresponding period of record for the Red River basin in North Dakota and Minnesota is given in attachment $A$.

Streamflow data used in this study were collected at streamflow-gaging stations on the Red River at Fargo and Grand Forks. Because this study is concerned with peak discharges and flood volumes that occur during the snowmelt-runoff period, peak discharges at Fargo and Grand Forks are listed in attachment $B$ and hydrographs for the snowmelt-runoff period March, April, and May for the entire period of record at Fargo and Grand Forks are plotted in attachment $C$. Peak-flow data are available for Grand Forks starting in 1882 and for Fargo in 1882, 1897 , and then continuously since 1902 . Daily flow data are available for Grand Forks starting in 1904 and for Fargo starting in 1902.

There have been some changes in published peakflow values on the Red River over the years. A complete review of the data was done in a 1955 compilation analysis (O.A. Crosby, U.S. Geological Survey, written commun., March 8, 1955). Based on improved hydraulic information available as a result of the 1979 flood, an adjustment was made to the 1882 and 1897 peak flows at Grand Forks (O.O. Holmen, U.S. Geological Survey, written commun., April 30, 1980).

\section{Climatological Data}

Climatological data are collected at more than 80 weather-observation stations by the U.S. Department of Commerce. The longest continuous records in the basin are available at the Fargo airport. This station was moved from Moorhead, Minn., in January 1881 (U.S. Army Corps of Engineers, 1956a, p. 10). There are a number of stations in the basin with records approximately 80 years long. However, the data generally are available only on magnetic tapes for years starting in 1940 or 1948. The data are available from the U.S. Department of Commerce, National Climatic Center, Asheville, N.C.

For this study a number of long-term records were obtained for use in the regression analysis. The majority of the North Dakota data were obtained on magnetic tapes. A small part, less than 1 percent, of the data were missing and were filled in by using regional data comparisons.

\section{PART 3-ANALYSES OF FLOOD RESPONSE}

Four hydrologic analyses have been completed in an attempt to identify any significant change in flood 
response of the Red River basin. These analyses have been based on the discharge data for the Red River at Fargo and Grand Forks. The analyses include floodfrequency, normalized-hydrograph, double-mass, and regression analyses.

\section{Flood-Frequency Analysis}

A flood-frequency analysis was developed to show the variation in flood flows on the Red River. A regionwide pattern in variation of flood flows is shown using streamflow records for a river from an adjacent basin. Also, the variation in flood flows is shown using floodfrequency analyses for selected short periods. The analysis was done using records from two periods-prior to 1950 and since 1950. Based on the history of basin changes, this break in periods was chosen to represent the time at which drainage impacts would be expected to become hydrologically significant. Also, because of the large number and magnitude of floods that have occurred since 1950, there has been concern that flooding has increased in recent years. Therefore, 1950 was chosen as a reasonable time at which to break the analysis to compare flood-frequency variations.

\section{Procedure}

The peak-flow-frequency analysis was developed using a log-Pearson Type III distribution following the U.S. Water Resources Council (1977) guidelines. Separate flood-frequency analyses were developed using the peak-flow records on the Red River at Fargo and Grand Forks. Two analyses were done at each site-one each for the period prior to 1950 and for the period since 1950 . The regional pattern in flood frequency was examined by applying the same analysis for the peak-flow records on the Mississippi River at St. Paul, Minn. Benson (1960) showed the large variation to be expected in predicted flood discharges if a short record is used in a floodfrequency analysis (fig. 3). This large variation was examined on the Red River by breaking the flood records at Fargo and Grand Forks into approximately 25 -year-long records and applying a flood-frequency analysis to each using the unadjusted systematic record.

\section{Discussion}

The flood-frequency analysis for the period since 1950 shows higher discharges for the same probability of recurrence at both Fargo and Grand Forks than the analysis for the period prior to 1950 (figs. 5 and 6). This is expected because of the large number and magnitude of floods that have occurred since 1950 . However, a large variation in flood flows with time is expected.

The results of the analysis on the Mississippi River (fig. 7) are similar to the results on the Red River. This upper Mississippi River basin is adjacent to the Red River basin. It has a $\mathbf{4 0}$ percent larger drainage area, $36,800 \mathrm{mi}^{2}$, than the Red River at Grand Forks, and has 110 years of flow record. The similarity in results indicates a regional pattern in the water-availability processes in the region. While the Mississippi River basin has experienced some land-use changes, extensive surface drainage and other land-use changes have not been adopted to the extent they have in the Red River basin. The variation in flood frequency experienced on the Red River since 1950 is due, at least in part, to a regionwide pattern of variation.

The results obtained by dividing the flood record into approximately 25 -year periods are shown in figures 8 and 9. They are plotted on arithmetic Gumbel probability paper to more closely match the plot developed by Benson (1960). The plots for the Red River do not exactly match the plots developed by Benson because he used the superseded Geological Survey flood-frequency analysis method, as described by Dalrymple (1960). The LogPearson Type III method used here results in floodfrequency curves for the Red River that are sometimes concave upward. The method used by Benson results in approximately straight lines. Figures 8 and 9 show a magnitude of variation in predicted flood frequencies between different periods similar to that shown by Benson.

The flood-frequency curve based on the record during the period 1882-1904 is actually slightly higher than the curve based on the record during the period 1955-79 (fig. 9). The variation in flood discharges described by the U.S. Department of Commerce (1954, p. 5) on the Mississippi River is similar to that on the Red River.

The results of the flood-frequency analysis show that the variation in flood frequency since 1950 as compared to the previous 50 years is due, at least in part, to a regionwide pattern of variation in flood frequency. The results further show that the kinds of variation in flood discharges experienced on the Red River are not greater than those expected to occur with time. Finally, the results show that the floods experienced in the late 1800 's were of similar frequency and magnitude as those that have occurred since the 1950's. This indicates that an adequate study of flood response changes on the Red River must include data for floods of the late 1800's.

\section{Normalized-Hydrograph Analysis}

An analysis of the snowmelt-runoff hydrographs on the Red River was done to evaluate possible changes 


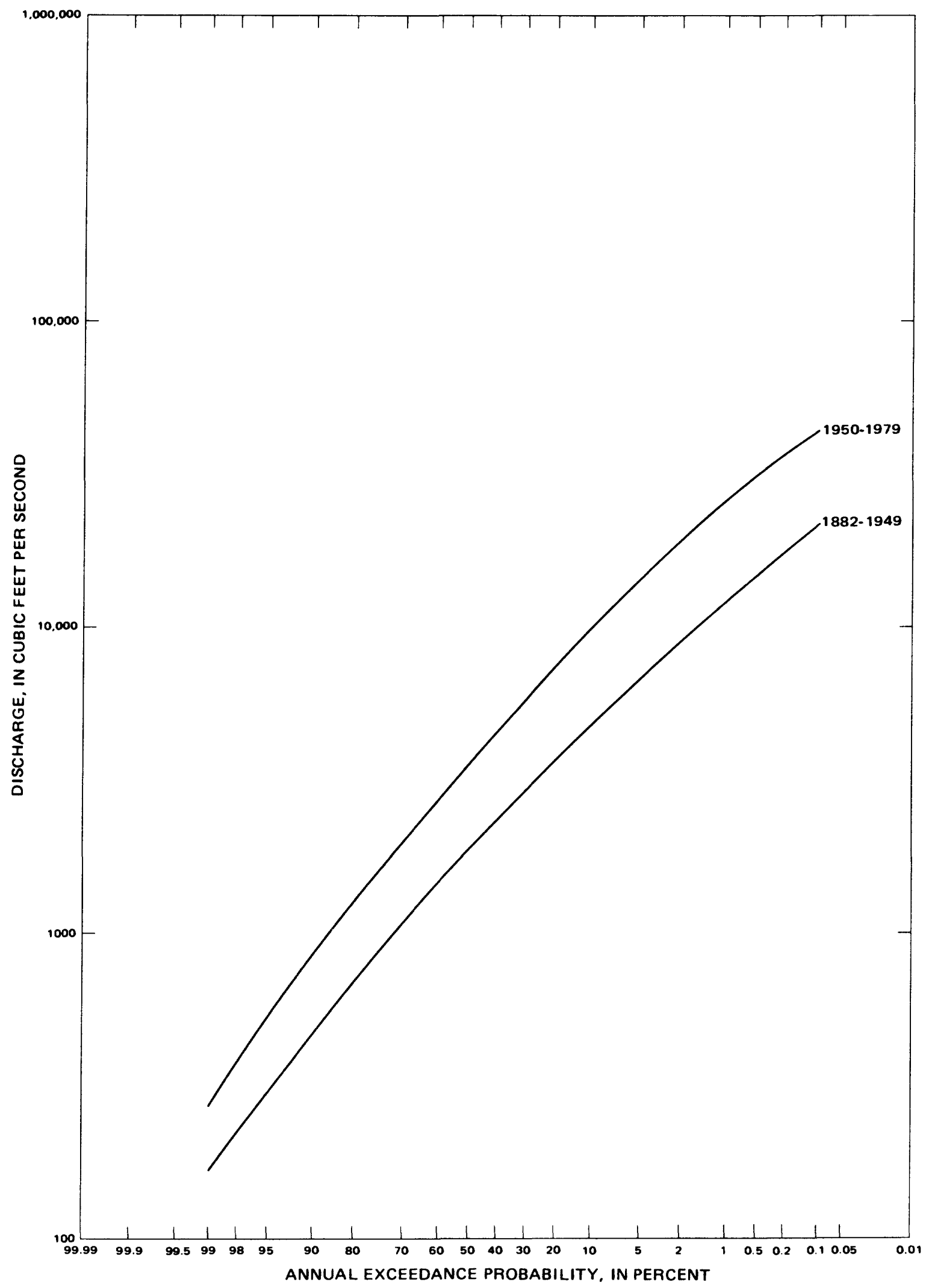

Figure 5. Annual peak-flow-frequency analysis for the Red River of the North at Fargo, N. Dak., for the two period of (a) 1882, 1897, and 1901-1949, and (b) 1950-1979. 


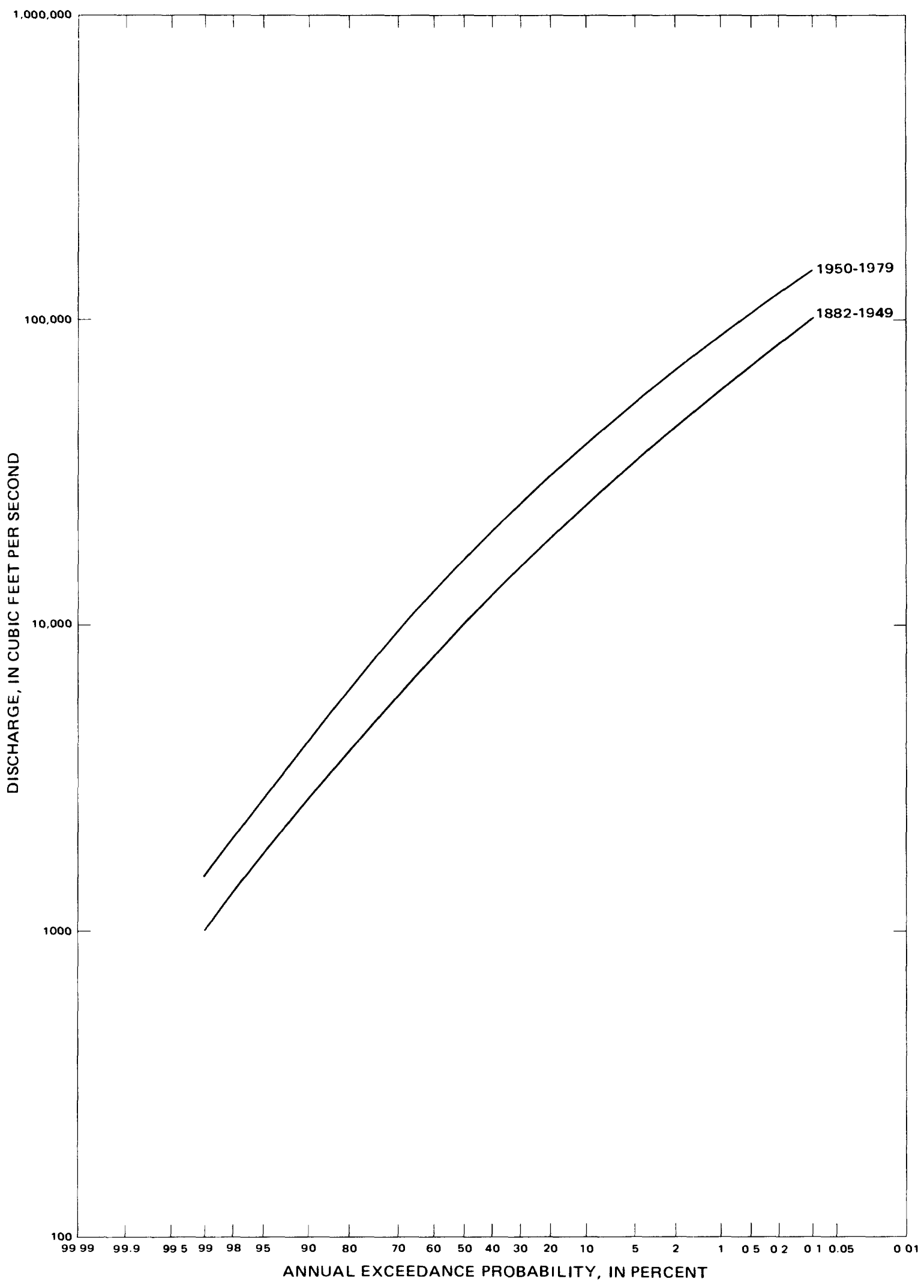

Figure 6. Annual peak-flow-frequency analysis for the Red River of the North at Grand Forks, N. Dak., for the two periods of 1882-1949 and 1950-1979. 


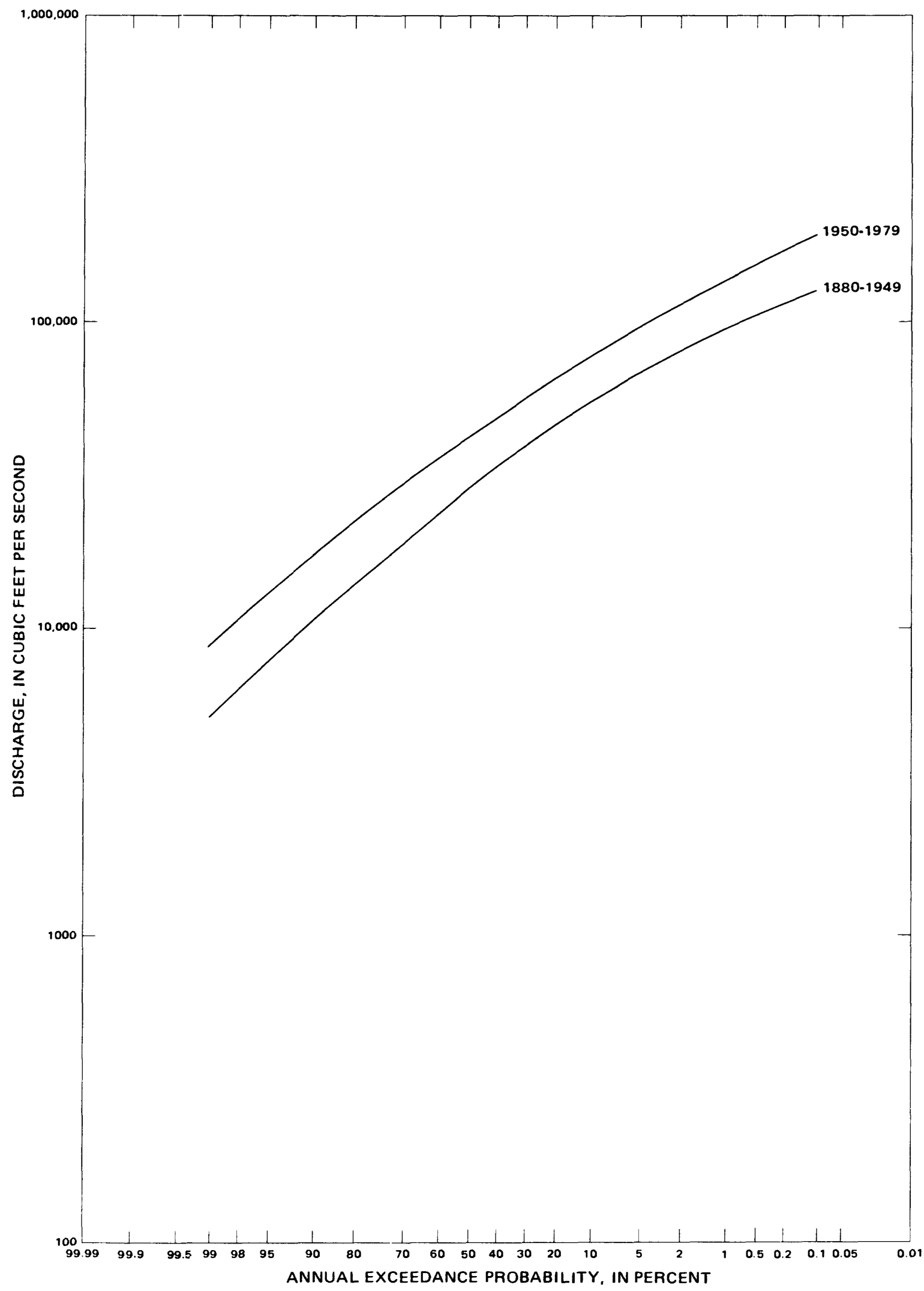

Figure 7. Annual peak-flow-frequency analysis for the Mississippi River at St. Paul, Minn., for the two periods of 1880-1949 and 1950-1979. 


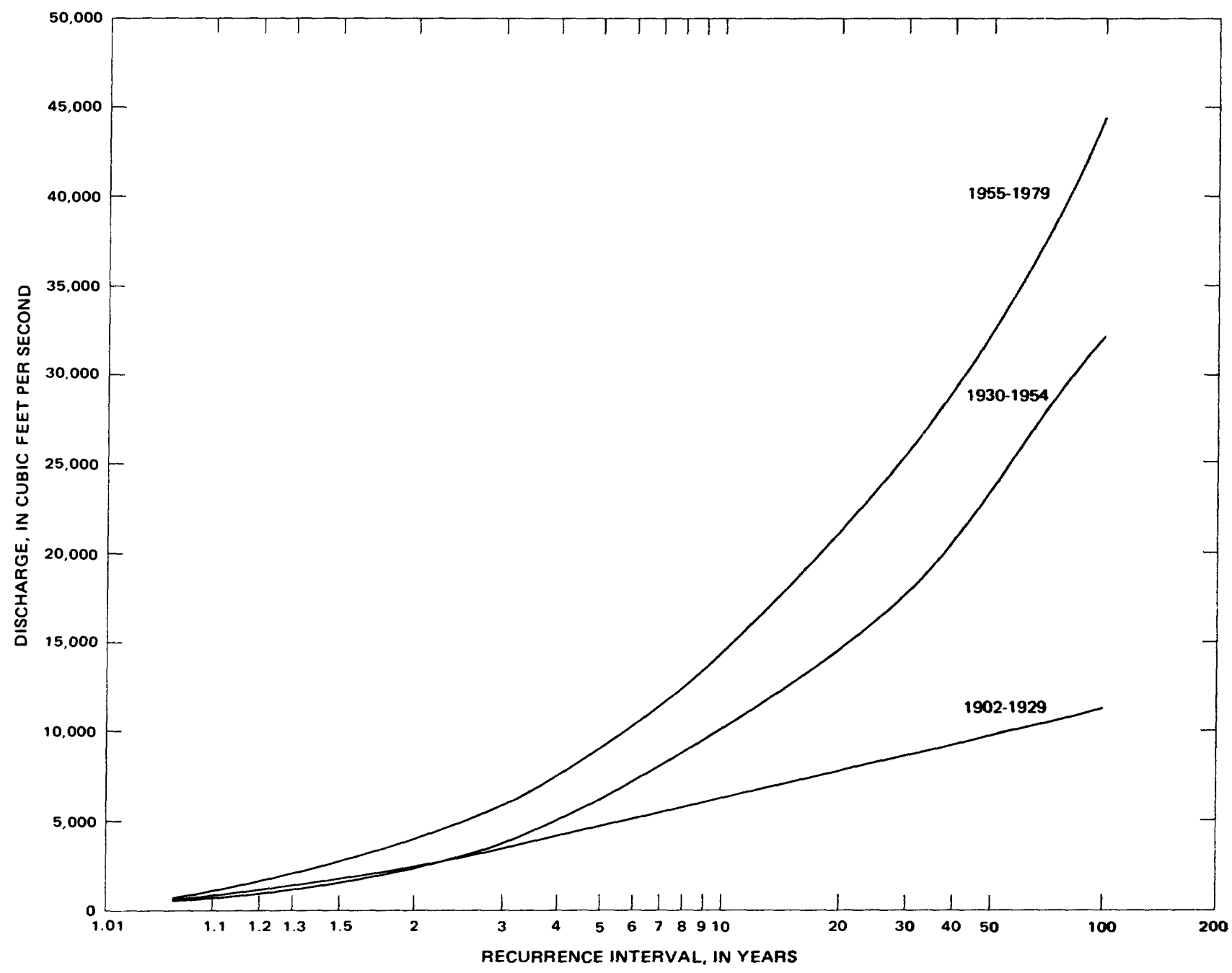
Figure 8. Annual peak-flow-frequency analysis for the Red River of the North at Fargo, N. Dak., for the three periods of
1902-1929, 1930-1954, and 1955-1979.

in shape of the hydrograph. A change in response may be indicated by a steeper rising hydrograph. Drainage and other land-use changes may increase the speed at which the excess water moves off the basin into the main stem, resulting in a shorter duration hydrograph with a greater peak discharge but with nearly the same volume. The purpose of the normalized-hydrograph analysis is to test the above conjecture. If this conjecture is true, it is expected that if a large number of hydrographs from predrainage and postdrainage periods were normalized, centered by the date of peak, and averaged for each period, the postdrainage averaged hydrograph would have less volume and steeper rising and falling limbs than the predrainage hydrograph.

The analysis was performed using the same two periods as in the flood-frequency analysis - the period prior to 1950 and the period since 1950 . However, only those hydrographs that met certain criteria were used in the analysis.

\section{Procedure}

The hydrographs used in the analysis were normalized so that they could be readily compared even though each individual mean daily discharge was different. This was done by including the discharge values for 15 days prior and following each hydrograph peak. Each ordinate on the hydrograph was divided by the peakdischarge value. This resulted in normalized-hydrograph ordinates that vary between 0 and 1 and hydrograph durations of 31 days, centered on the 16 th day by the date of the peak discharge.

Hydrographs were chosen by inspection to remove those hydrographs from the analysis that did not provide a useful characterization of a simple runoff-hydrograph shape. Hydrographs were chosen using the following 


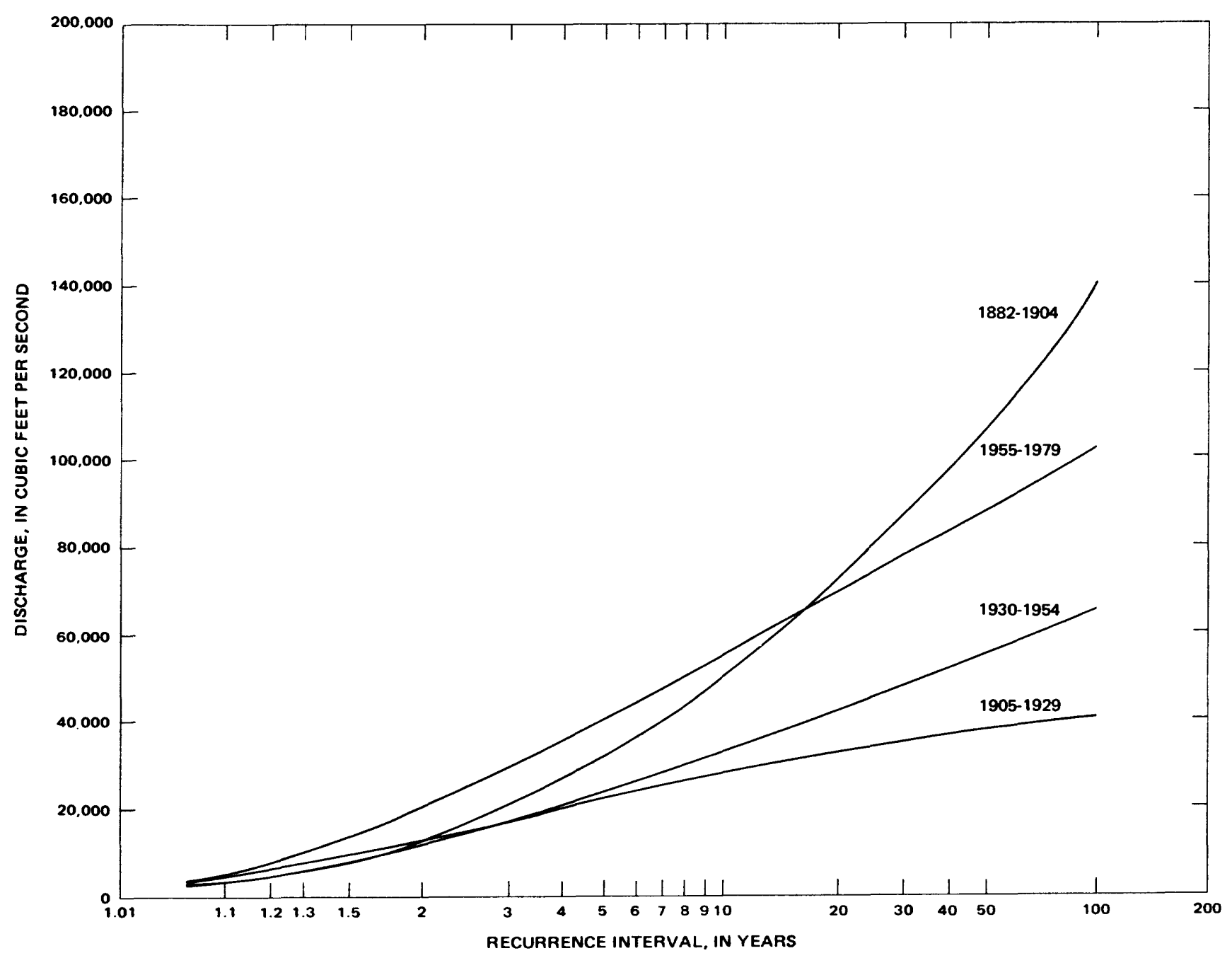

Figure 9. Annual peak-flow-frequency analysis for the Red River of the North at Grand Forks, N. Dak., for the four periods of 1882-1904, 1905-1929, 1930-1954, and 1955-1979.

criteria:

1. Resulted from a snowmelt-runoff event.

2. Included only one main peak.

3. Peak discharge greater than approximately 4,000

$\mathrm{ft}^{3} / \mathrm{s}$ at Fargo and greater than approximately 10,000

$\mathrm{ft}^{3} / \mathrm{s}$ at Grand Forks.

4. Complete daily record for the 31-day period.

5. No other complications in the shape.

Based on the above criteria, hydrographs were chosen from the records collected on the Red River at Fargo and Grand Forks. The hydrographs chosen are listed in table 10.

Each hydrograph was normalized and then plotted on one of four plots-one for each period at both Fargo and Grand Forks (fig. 10). The normalized hydrographs were then averaged within each period at both stations. The averaged normalized hydrographs are shown in figures 11 and 12. The ordinates are the average of each ordinate in the period for each day. The ratios of area under the hydrograph for the period since 1950 to the area under the hydrograph for the period prior to 1950 were 1.04 at Fargo and 0.99 at Grand Forks.

\section{Discussion}

All of the individual normalized hydrographs are shown in figure 10 to show the variation in hydrographs that make up the averaged normalized hydrographs. The averaged normalized hydrographs shown in figures 11 and 12 show a slightly steeper rising limb and a slightly flatter falling limb for the period since 1950 hydrographs.

The area under the hydrographs is greater for the period since 1950 at Fargo and smaller for the same period at Grand Forks. A change in response in recent years might be indicated by a shorter duration hydrograph for the period since 1950 than before 1950. A 
Table 10. Years from which snowmelt-runoff hydrographs for the Red River of the North were chosen to be included in the normalized-hydrograph analysis

\begin{tabular}{llll}
\hline \multicolumn{2}{c}{ Red River at Fargo } & \multicolumn{2}{c}{ Red River at Grand Forks } \\
Period one & Period two & Period one & Period two \\
\hline 1905 & 1950 & 1904 & 1951 \\
1910 & 1951 & 1908 & 1952 \\
1920 & 1952 & 1910 & 1954 \\
1923 & 1956 & 1915 & 1955 \\
1928 & 1960 & 1916 & 1956 \\
1929 & 1962 & 1917 & 1960 \\
1939 & 1965 & 1920 & 1962 \\
1943 & 1966 & 1921 & 1963 \\
1945 & 1967 & 1922 & 1964 \\
1946 & 1969 & 1923 & 1965 \\
1947 & 1972 & 1928 & 1966 \\
1948 & 1974 & 1929 & 1967 \\
& 1975 & 1932 & 1969 \\
& 1976 & 1936 & 1971 \\
& 1978 & 1940 & 1973 \\
& 1979 & 1941 & 1974 \\
& 1980 & 1942 & 1975 \\
& & 1943 & 1976 \\
& & 1945 & 1978 \\
& & 1946 & 1979 \\
& & 1947 & 1980 \\
& & 1948 & \\
& & 1949 & \\
& & &
\end{tabular}

Total number of years

shorter duration hydrograph when normalized would have both a steeper rising and falling limb and a smaller area under the hydrograph. While the steepness of the averaged normalized hydrographs does differ between the two periods, the difference is not significant when compared to the large variation in individual hydrographs used to develop the averages. Also, the results are not consistent between the rising and falling limbs. The difference in areas between the periods is small when compared to the variation in the individual hydrographs. Again, the results are not consistent. At Fargo the area ratio of the period since 1950 to before 1950 is larger than 1 , and at Grand Forks it is smaller than 1 .

The results of the normalized-hydrograph analysis did not show a large enough variation between the two periods or a variation consistent enough with what would be expected to indicate a response change of the basin. Finally, the analysis is severely limited because it does not include data from the late 1800 's.

\section{Double-Mass Analysis}

A double-mass analysis was done to compare possible changes in runoff characteristics between the Red River and comparison streams. The analysis was applied to the Red River at Grand Forks twice, once using the group of comparison streams and once using the Missis- sippi River at St. Paul. The comparison streams are the Crow Wing River at Nimrod, Minn., the Little Fork River at Little Fork, Minn., and the Cannonball River at Breien, N. Dak. The Mississippi River was added to the analysis because it is an adjacent basin to the Red River basin and has a similar drainage area and period of record.

The analysis included two comparisons-one based on the cumulative snowmelt-runoff volume, in inches, and the second based on the cumulative peak discharge, in cubic feet per second per square mile of drainage area. The snowmelt-runoff volume is the total runoff volume during March, April, and May expressed as inches of depth over the basin drainage area. These two separate analyses will be referred to as the runoff-volume and peak-discharge analyses.

The double-mass analysis is based on the concept that the cumulation of runoff characteristics between the stream to be examined and the comparison streams would plot as a straight line independent of the magnitude and frequency of the runoff events. The slope of this line represents the constant of proportionality between the two streamflow records. This linear relationship must be tested to determine whether the analysis is valid. When a change in response occurs for one basin only, the linear relationship should change, producing a break in slope and, thus, a change in the constant of proportionality of the cumulative runoff curves. The double-mass analysis uses other streams to compare the results of the complex runoff processes. This is done by using the comparison streams to integrate all of the processes into the runoff records collected at the downstream gage.

Based on the history of basin changes, if a change in slope occurred in the double-mass curves indicating a response change, it should occur at approximately 1950 . Also, if a change in response occurred due to drainage and other land-use changes, the slope of the curve should increase following 1950, indicating a larger amount of runoff from the Red River basin.

\section{Procedure}

The double-mass analysis was applied to the Red River following the procedures described in Searcy and Hardison (1960). As they suggested, an analysis was done for both the snowmelt period runoff volumes and the peak discharges based on mean daily streamflow data.

The mean daily streamflow data were retrieved from the U.S. Geological Survey WATSTORE computer-storage system, and the double-mass analysis was performed using the SAS statistical analysis system (SAS Institute, Inc., 1979). The data from the comparison stations were analyzed to determine the snowmelt-runoff 

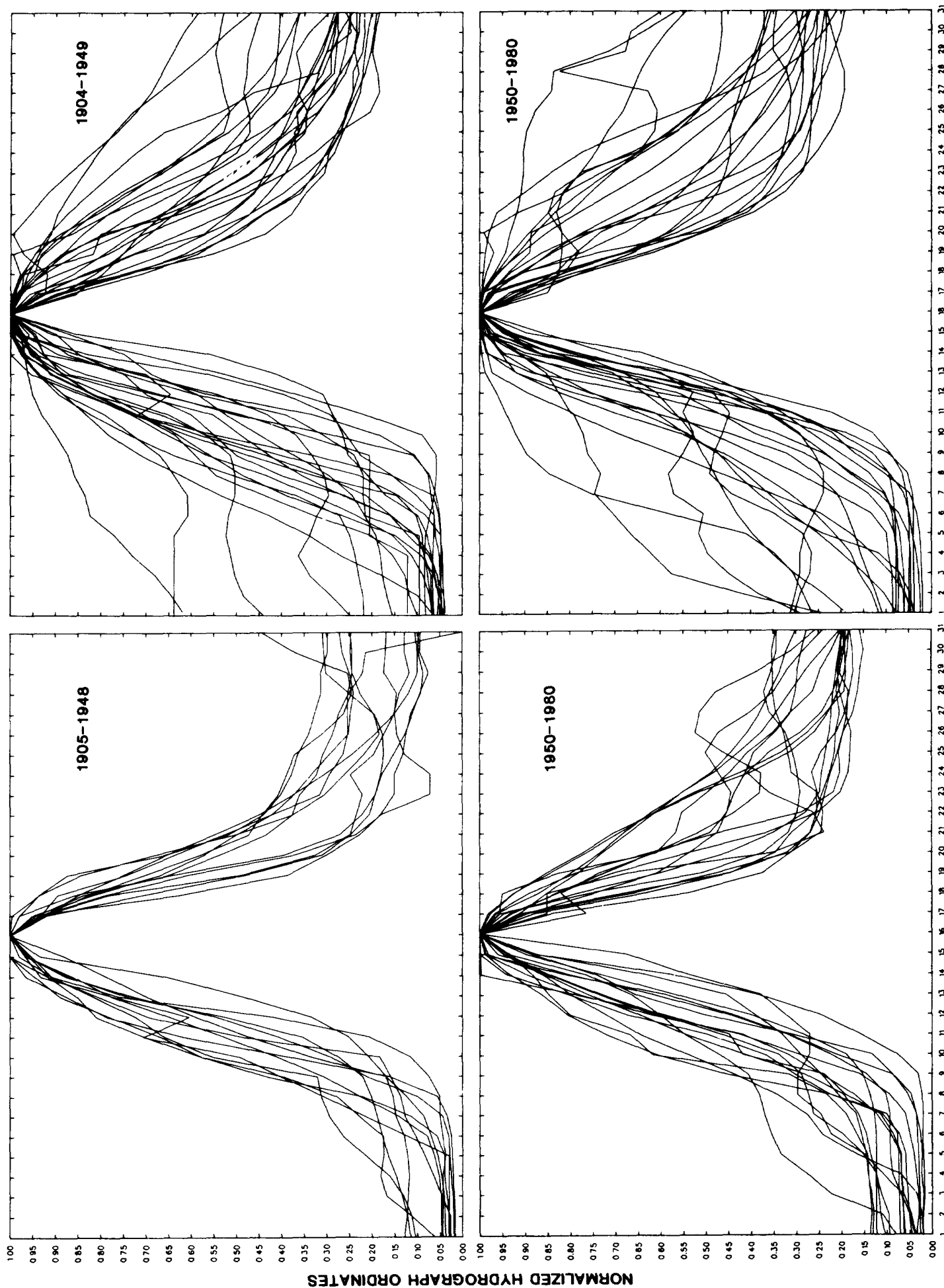

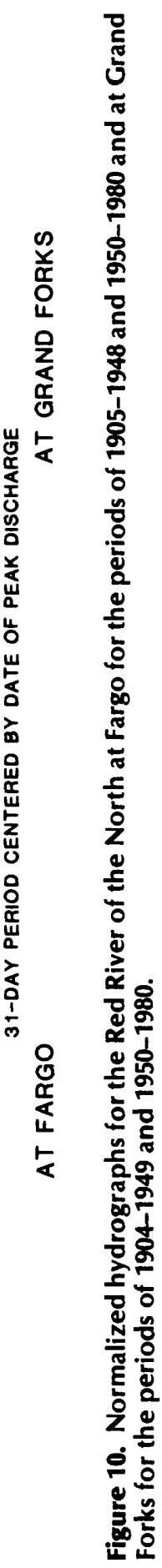




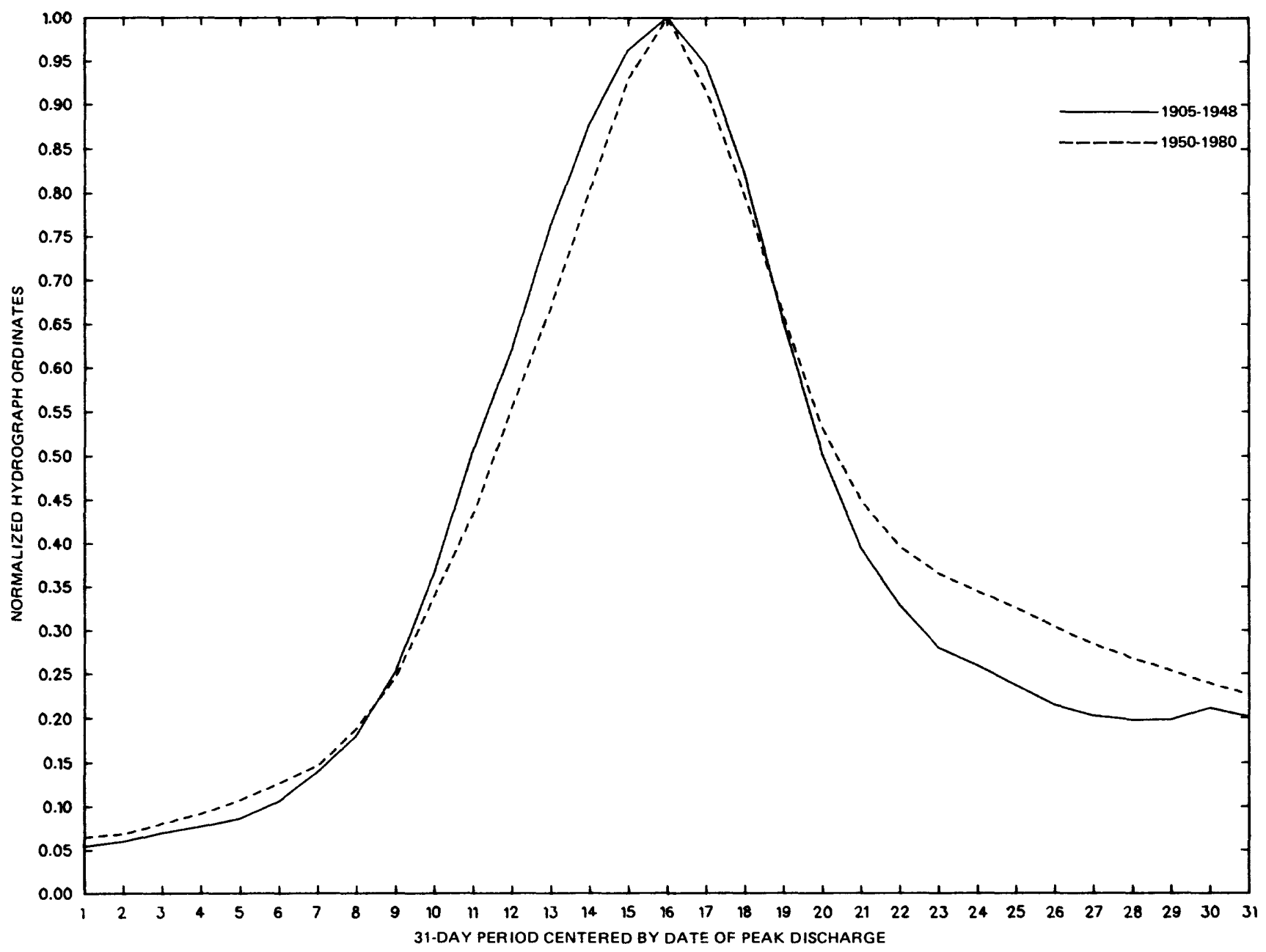

Figure 11. Averaged normalized hydrographs for the Red River of the North at Fargo for the periods of 1905-1948 and 1950-1980.

volumes and snowmelt-peak discharges and then were averaged. The Red River at Grand Forks and the Mississippi River at St. Paul were analyzed individually in a similar manner. In the peak discharge analysis, using the Mississippi River at St. Paul, the records were extended backwards in time from 1903 to 1882 using instantaneous peak-discharge values instead of mean daily discharges. The values for each individual year were then cumulated and plotted. Finally, the required statistics were computed so that an analysis of covariance could be performed on any changes in the slope of the double-mass curve that were identified. The analysis of covariance is used to statistically test whether two regression lines are significantly different. It is used to test whether an apparent change in slope is likely due to chance or to an actual change in runoff characteristics.

Each double-mass curve was examined to identify changes in slope. Lines were drawn where apparent changes in slope occurred. The results of the analysis using the peak-discharge data for the Mississippi River at St.
Paul are shown in figures 13 and 14.

\section{Discussion}

A detailed evaluation of the double-mass analysis indicates that the constant of proportionality actually varies depending on the magnitude of flood events. Because of the large variation in flood flows with time that occurs on the Red River, this variation severely limits the adequacy of the analysis for evaluating the Red River response-change problem. However, the results are given here because they show that a long period of record is required to study changes in flood response. The only station with a long enough record to include the late 1800 's for comparison with the Red River is the Mississippi River at St. Paul. Therefore, the following discussion includes only the Mississippi River analysis.

In figure 13, the lines drawn show an apparent break in slope at 1964-65 if the analysis is done ignoring the record prior to 1904. An expected break in slope at 


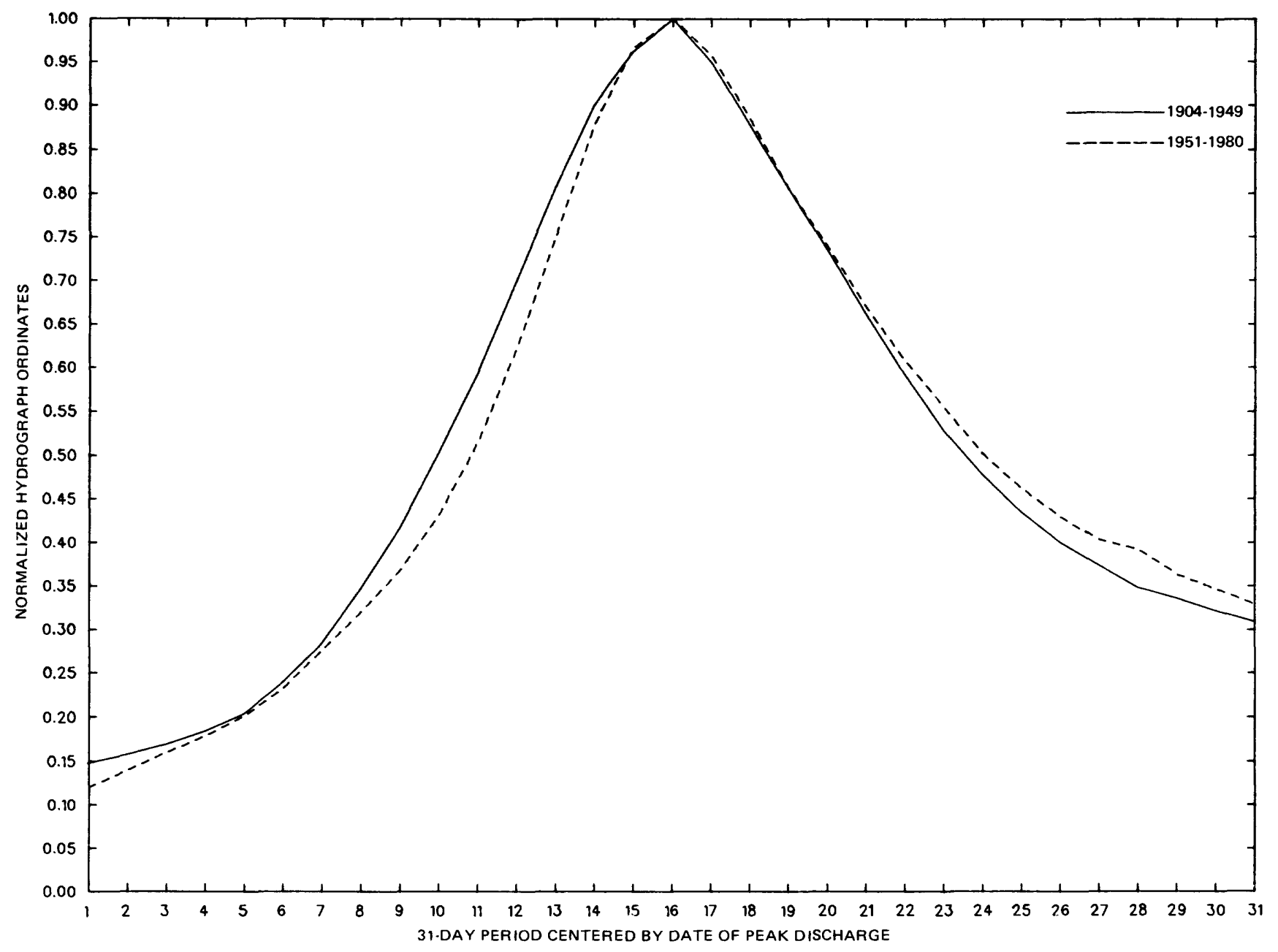

Figure 12. Averaged normalized hydrographs for the Red River of the North at Grand Forks for the periods of 1904-1949 and 1951-1980.

about 1950 does not appear in the analysis. No reason for a change at 1964- 65 has been identified, although considerable drainage development continued through the 1950 's and 1960's. If the period prior to 1904 is ignored, a statistical test of the change in slope, at 1964-65 is significant at the 5-percent level. (There is only a 5-percent chance that the change in slope is due to chance and not due to a change in the relation.) If the record prior to 1904 is included in the analysis, the break in slope at $1964-65$ is not significant.

If the record prior to 1909 is examined independently, a best-fit line drawn through the points results in a steeper slope than that for the period following 1950 (fig. 14). Because there is no known reason for a response change following 1908 , this is probably a spurious break caused by the inherent variability in the hydrologic data (Searcy and Hardison, 1960, p. 34). Similarly, the break following 1964 is also assumed to be spurious. It appears that during a period in which a number of large floods occur the analysis gives a steeper slope than during other periods-independent of any response changes.

The flood-frequency analysis showed that the floodfrequency characteristics of the 25 years prior to 1906 are similar to those since 1955 . The results of the doublemass analysis show that the period of record prior to 1909 gives a steeper slope similar to the period of record since about 1960 . The double-mass analysis also showed that if the period of record prior to 1904 is not included in the analysis a spurious response change is apparent. This indicates that any response-change study based on past records must include at least the last 20 years of the 1800's in order to provide an adequate basis for comparison on the Red River main stem. A long period of record is needed because of the expected large variation in flood discharges with time. The flood-flow characteristics of the late 1800's appear to be similar to those for the period since about 1950 or 1960 . The period between approximately 1910 and 1950 is not similar to either of the early or late periods described above, and does not provide an adequate basis for comparison to recent records when 


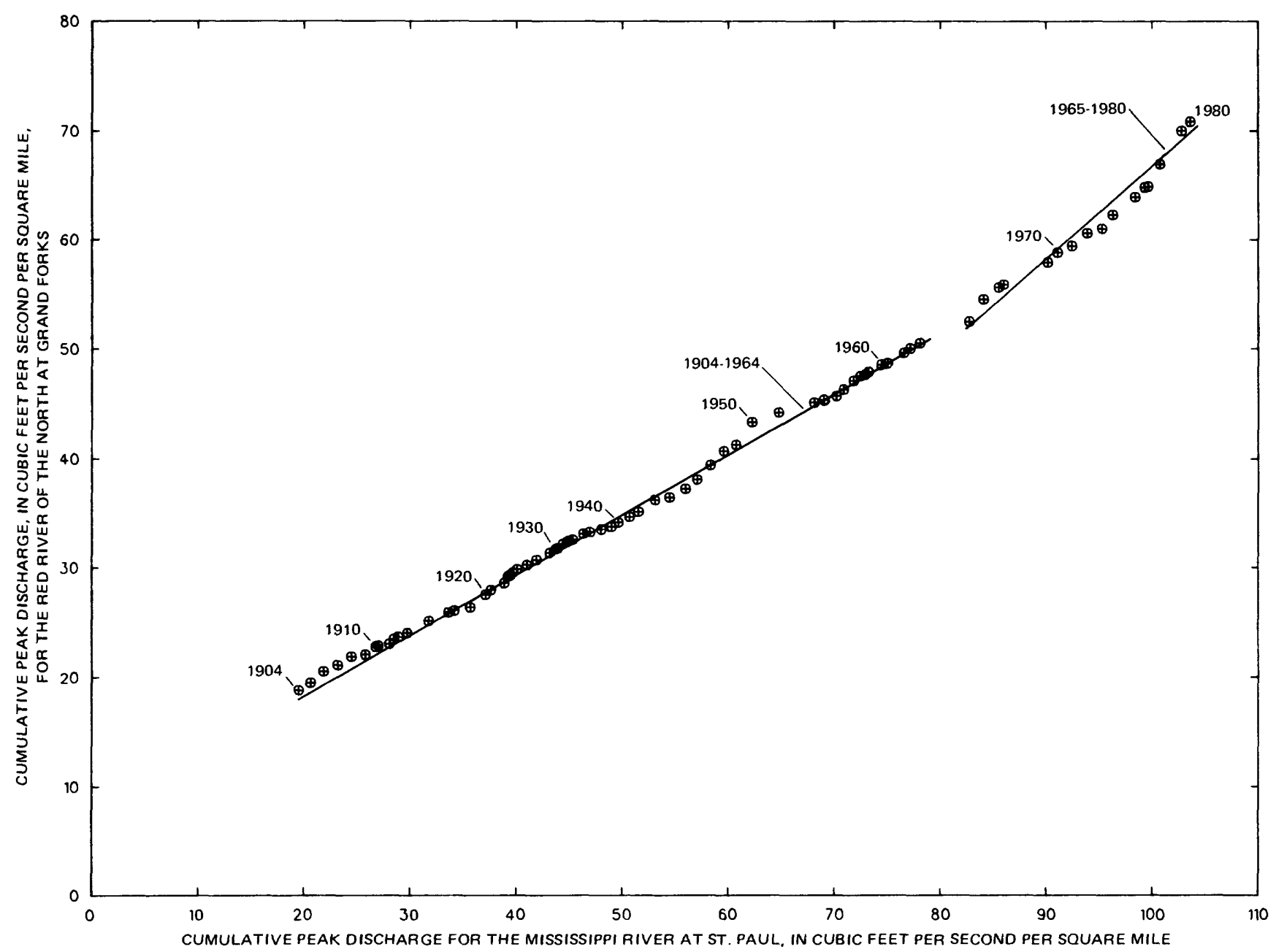

Figure 13. Double-mass analysis using peak-discharge data from 1904 to 1980.

studying a possible change in the complex Red River runoff processes.

The results of the remaining double-mass analyses are not included here because only the peak-discharge analysis between the Red River at Grand Forks and the Mississippi River at St. Paul could be extended back into the 1800's. The remaining analyses have various apparently spurious breaks in slope because they do not include streamflow records from the late 1800 's. The remaining analyses only compare the early 1900 's to the period since 1950. Therefore, they are inadequate for identifying a response change of the Red River basin.

\section{Regression Analysis}

The objective of the regression analysis was to evaluate the importance of selected climatic parameters and a qualitative land-use parameter (based on a subjective evaluation of drainage and other land-use changes) on snowmelt flooding in the Red River basin. Because many of the largest historical and recorded floods occurred in the 19th century (table 8), an attempt was made to obtain pre-1900 climatological data. The 1897 flood was of particular interest because it exceeded all recorded floods. Although insufficient data prevented including other floods of the 1800's, the best estimates using available data were tested against the model results for the Red River at Grand Forks.

\section{Procedure}

The regression analysis utilized multiple-regression techniques to compare selected climatological data to recorded streamflow data. The regression model used in this analysis was of the form

$$
Q_{\mathrm{N}}=a+b_{1} C_{1}+b_{2} C_{2}+b_{3} C_{3}+\ldots b_{\mathrm{N}} C_{\mathrm{N}}
$$

where

$Q_{\mathrm{N}}=$ the flow parameter,

$a$ the regression constant,

$b_{1}, b_{2}, b_{3}$, and $b_{\mathrm{N}}=$ regression coefficients assigned to individual climatic variables, 


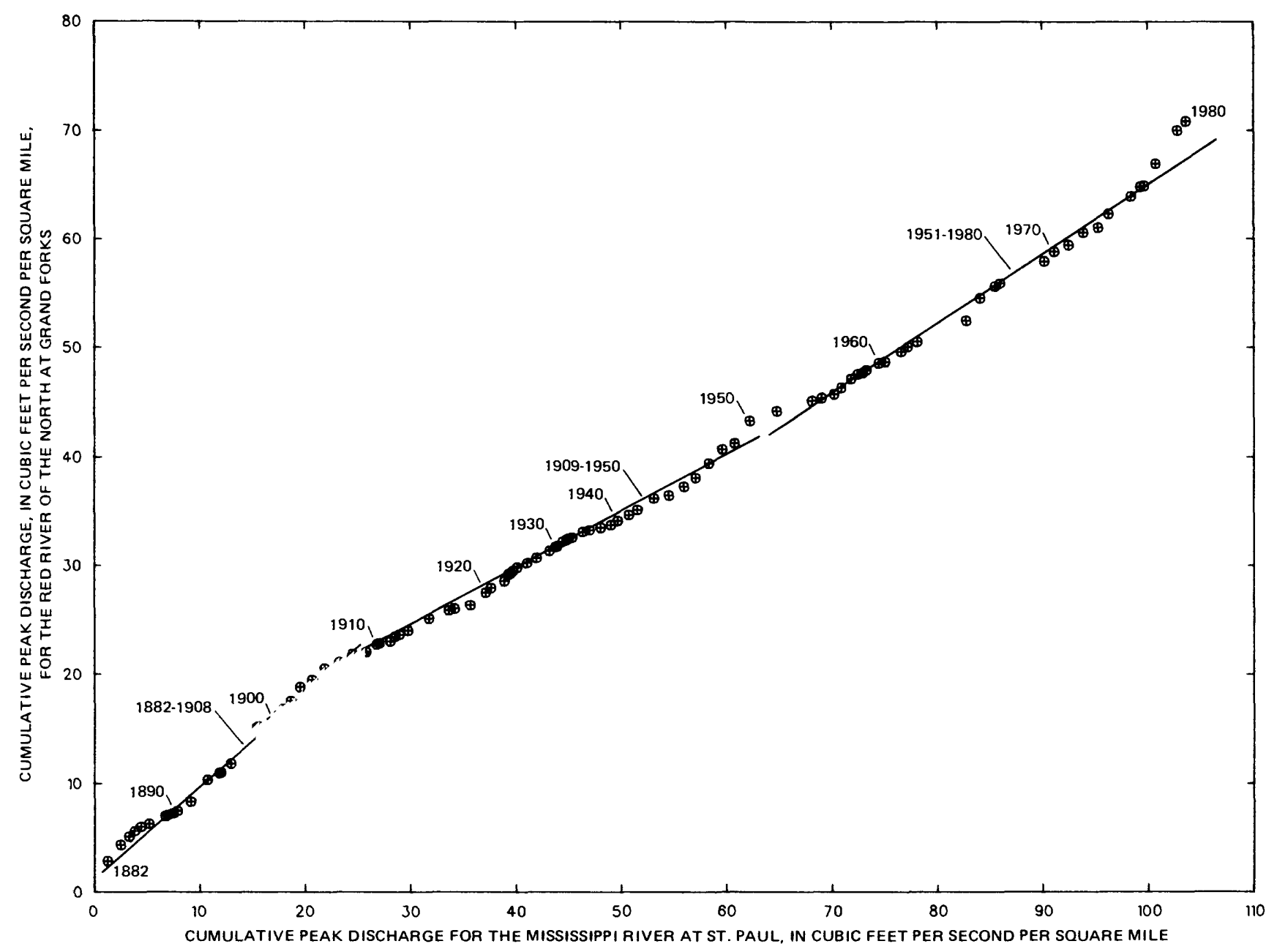

Figure 14. Double-mass analysis using peak-discharge data from 1882 to 1980.

and

$C_{1}, C_{2}, C_{3}$, and $C_{\mathrm{N}}=$ climatic and land-use parameters such as precipitation and temperature.

\section{Data development}

The time periods studied were 1897 to 1980 (84 years) for snowmelt peak flows and 1904 to 1980 (77 years) for snowmelt volumes. The availability of data was the main reason for selecting the time periods. Continuous streamflow data were not available prior to 1904 , although peak-flow data were consistently collected as early as 1882 at Grand Forks.

The peak discharges were the maximum flows recorded during the snowmelt period at Fargo and Grand Forks. These peak discharges were usually the maximum flow during the period March through May. However, the peaks were checked against the daily temperatures to insure that the peaks were the result of snowmelt. If the maximum peak was largely the result of rainfall, the highest previous peak was used. The flood-volume data included the highest 30-day volume corresponding to the snowmelt peak.

A total of 15 precipitation station records were analyzed to determine weighted monthly precipitation over the Red River basin above Fargo and Grand Forks. The stations included nine North Dakota stations and six Minnesota stations. The locations of these stations are shown in figure 15 . The Thiessen polygon method was used to weight the station records for use in the regression analysis. Minor adjustments were made to the results of the Thiessen method based on the correlation of each station to the annual peak discharges. The final weighting factors are shown in table 11.

\section{Parameter development}

The climatic data were arranged into various parameters for the regression analysis. For most of the parameters, several possibilities for development of the parameter were tried and the most hydrologically desirable were selected. The parameters were developed to 


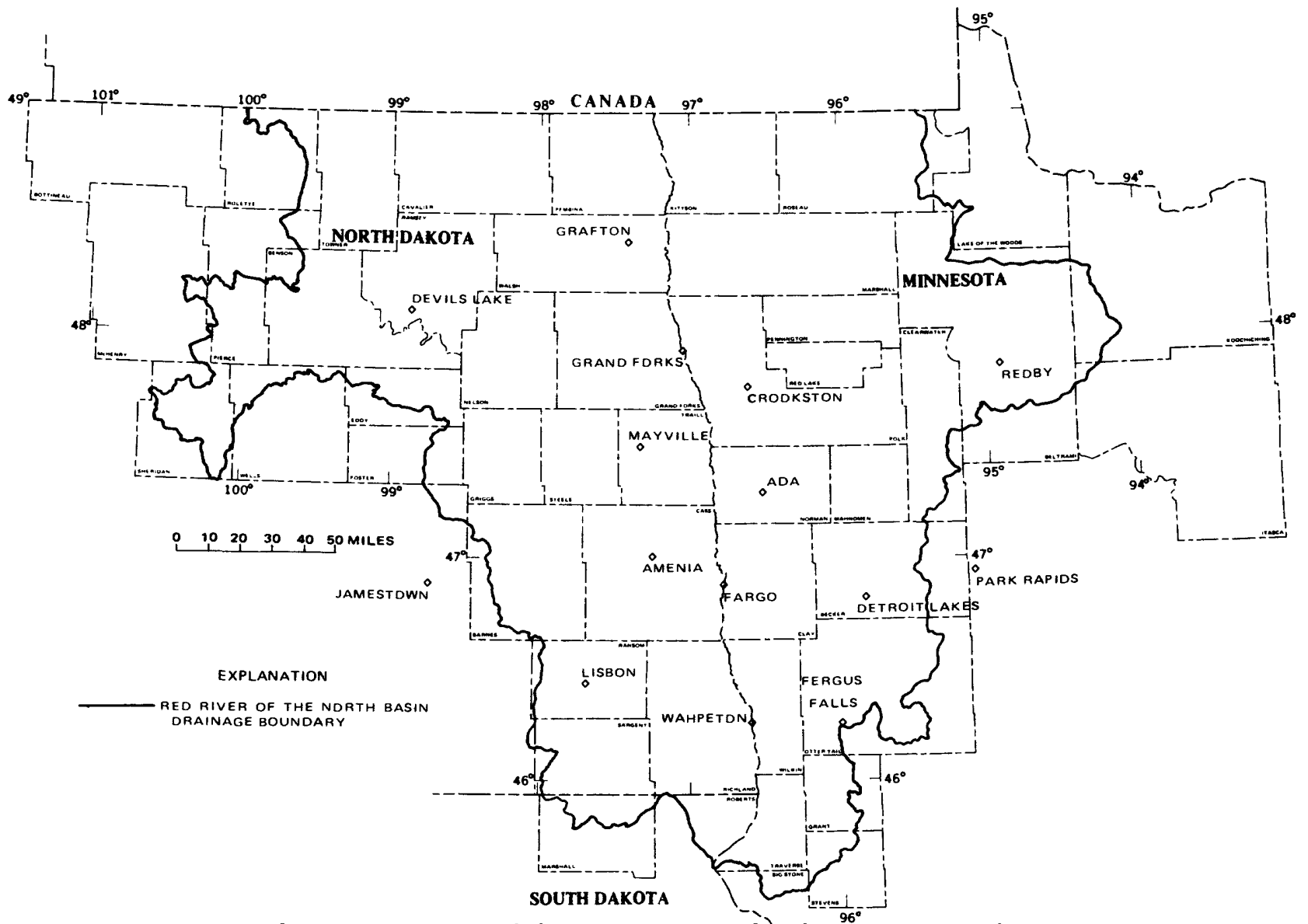

Figure 15. Locations of climatic stations used in the regression analysis.

Table 11. List of climatological stations and the factors used to compute the weighted monthly precipitation over the Red River of the North basin

\begin{tabular}{lcc}
\hline \multicolumn{1}{c}{ Station } & $\begin{array}{c}\text { Red River basin } \\
\text { above Grand Forks }\end{array}$ & $\begin{array}{c}\text { Red River basin } \\
\text { above Fargo }\end{array}$ \\
\hline Lisbon & 0.07 & 0.07 \\
Wahpeton & .11 & .3 \\
Fergus Falls & .05 & .33 \\
Fargo & .06 & .3 \\
Detroit Lakes & .07 & 0 \\
Jamestown & .04 & 0 \\
Amenia & .05 & 0 \\
Park Rapids & .05 & 0 \\
Ada & .08 & 0 \\
Mayville & .10 & 0 \\
Devils Lake & .04 & 0 \\
Grand Forks & .04 & 0 \\
Crookston & .10 & 0 \\
Redby & .09 & 0 \\
Grafton & .05 & 0 \\
$\quad$ Total & 1.00 & 1.00 \\
\hline
\end{tabular}

describe the snowmelt process as accurately as possible. Precipitation data were developed into primarily four categories: (1) Antecedent-moisture index, (2) winter precipitation, (3) snowmelt precipitation or amount of precipitation that occurred during the snowmelt period, and (4) precipitation that occurred after the day of peak flow but before the end of the high 30-day volume so that it influenced total volume.

The antecedent-moisture index was calculated by weighting monthly precipitation totals from the previous year as follows:

$I_{\mathrm{AM}}=0.08 P_{\mathrm{m}}+0.09 P_{\mathrm{jn}}+0.1 P_{\mathrm{jl}}+0.12 P_{\mathrm{a}}+0.3 P_{\mathrm{s}}+0.3 P_{\mathrm{o}}$,

where

$I_{\mathrm{AM}}=$ antecedent-moisture index,

$P_{\mathrm{m}}=$ May precipitation,

$P_{\mathrm{jn}}=$ June precipitation,

$P_{\mathrm{jl}}=$ July precipitation,

$P_{\mathrm{a}}=$ August precipitation,

$P_{\mathrm{s}}=$ September precipitation,

and

$P_{0}=$ October precipitation. 
The winter-precipitation parameter used in this analysis was the total precipitation that occurred from November 1 to the day of the peak at Fargo and Grand Forks. The November precipitation totals were compared with temperature. If the November precipitation appeared to be the result of rain, winter precipitation was reduced and the antecedent-moisture index increased.

The winter-temperature index was developed from Fargo data only, based on the following equation:

$$
I_{\mathrm{WT}}=0.2 T_{\mathrm{d}}+0.3 T_{\mathrm{j}}+0.5 T_{\mathrm{f}},
$$

$$
\begin{array}{cl}
\text { where } & \\
I_{\mathrm{wr}} & =\text { winter-temperature index, } \\
T_{\mathrm{d}} & =\text { December mean monthly temperature, } \\
T_{\mathrm{j}} & =\text { January mean monthly temperature, } \\
\text { and } & \\
T_{\mathrm{f}} & =\text { February mean monthly temperature. }
\end{array}
$$

The snowmelt index was the most difficult parameter to develop because of the complexity of the process and the lack of data necessary to adequately describe the process. The index was developed from daily temperature data at Wahpeton, Fargo, and Grand Forks. The index was defined as the mean degree days from the day the temperature reached $30^{\circ} \mathrm{F}$ to 2 days before the actual snowmelt peak flow. Adjustments were made as follows: (1) the minimum snowmelt length was 5 days, and (2) the maximum degree days were determined to be winter precipitation divided by a relatively low melt rate for open areas -0.06 inches per degree day. The resulting degree days were thought to be sufficient to melt the snowpack during an average to moderately fast melt period. Separate snowmelt indexes were developed based on the climatological data at Wahpeton, Fargo, and Grand Forks and combined for the Red River as follows:

$$
I_{\mathrm{GS}}=0.3 S_{\mathrm{w}}+0.4 S_{\mathrm{f}}+0.3 S_{\mathrm{g}} \text {, }
$$

where

$\begin{array}{cl}I_{\mathrm{GS}} & =\text { Grand Forks snowmelt index, } \\ S_{\mathrm{w}} & \text { Wahpeton snowmelt, } \\ S_{\mathrm{f}} & =\text { Fargo snowmelt, } \\ \text { and } & \\ S_{\mathrm{g}} & \text { Grand Forks snowmelt; } \\ \text { and } & \end{array}$

$$
I_{\mathrm{FS}}=0.5 S_{\mathrm{w}}+0.5 S_{\mathrm{f}},
$$

where

$I_{\mathrm{FS}}=$ Fargo snowmelt index.

Other independent parameters analyzed included (1) the previous snowmelt peak and 30-day volume, limited to a maximum of $30,000 \mathrm{ft}^{3} / \mathrm{s}$ and 500,000 acre-feet at Grand Forks and $8,000 \mathrm{ft}^{3} / \mathrm{s}$ and 100,000 acre-feet at Fargo; and (2) the lag time in days between the Fargo and Grand Forks peaks. These parameters were included to provide an indication of previous flood affects on antecedent conditions, and peak synchronization.

In addition to the above parameters, a qualitative index was developed that corresponded to the amount of land-use changes and drainage that have occurred in the basin. Although drainage was the main consideration in the development of the land-use parameters, several other changes have also occurred. Farming practices, acres under cultivation, and bridges and other structural enlargements have all coincided with drainage. Therefore, the land-use index should not be thought of entirely as a drainage index. This parameter was developed from reviewing historical reports and from general knowledge of the basin. Significant land-use changes began in the late 1800 's and continued to increase during the early 1900 's. As the flooding problems decreased in the late 1920 's and 1930's, few water-related projects were added and many of the early projects were allowed to deteriorate. The number of water projects were allowed to deteriorate. The number of water projects increased significantly after World War II from the construction of many legal drains and in the late 1960's and 1970's from an increase in private drains.

To provide values for the qualitative index, it was decided that it should vary between zero and approximately 100 . The amount of change during each time period was then made proportional to the total change. After the initial index was developed it was determined that the index should increase more rapidly starting at about 1965. As a result, the index used in the analysis varies from zero to approximately 108 . The land-use index that was developed and used in the regression analysis is shown in figure 16. The Soil Conservation Service (Charles E. Mumma, written commun., 1981) has suggested that the land-use index should increase at a greater rate so that the period 1920 to 1945 would use a higher index to account for the fast rate at which cropland was developed in the basin. However, cropland development is only a part of the land-use changes considered. It is, therefore, noted that this is a qualitative parameter and there is some question as to how this index should vary.

Graphical plots of the individual parameters used in the regression analysis are included in the attachments. Attachment $D$ shows plots of the peak discharges by year at Fargo and Grand Forks. Attachment E shows plots of the 30-day high-snowmelt volumes by year for Fargo and Grand Forks. Attachment F shows plots of the antecedent-moisture index by year for Fargo and Grand Forks. Winter precipitation is shown in attachment $G$, winter 


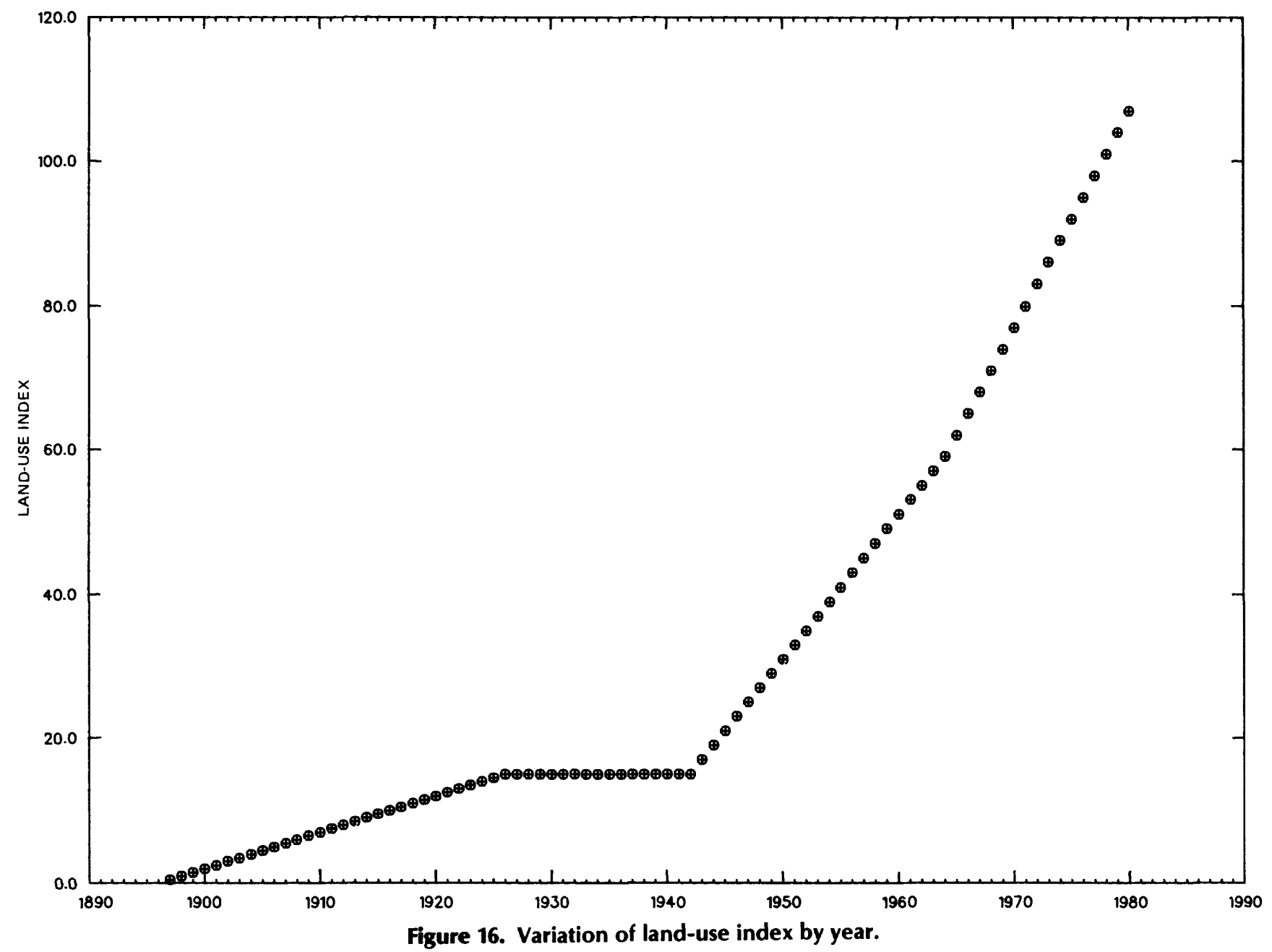

temperature is shown in attachment $\mathrm{H}$, and the snowmelt index is shown in attachment $I$.

A problem that existed throughout the development of the parameters was a lack of adequate data needed to describe the many processes affecting flooding, particularly snowmelt flooding. The most significant hydrologic processes that affect the magnitude of floods are listed in table 7. Many of these processes-radiation and several others - have been measured and recorded for the last 10 to 20 years. Only limited temperature and precipitation data were available during the very important 1800 's and early 1900 's. Considerable efforts were made to obtain wind data, but wind velocity was only available after 1950 . Therefore, a certain amount of error can be expected from the lack of available data. The hydrologic processes described in table 7 and an estimate of how completely the data used in the regression analysis described each process are listed in table 12.

\section{Discussion}

The results of the regression study are shown in two forms. The first is a series of four multiple-regression equations, one for each dependent parameter. These equations provide the best fit of the climatic and landuse-index variables to the flow parameters. The second method of presentation is a series of plots showing actual and predicted streamflow values.

The regression equation (model) for the peak discharge at Fargo is

$$
\begin{aligned}
Q_{\mathrm{F}}= & -3,940+1,265 W_{\mathrm{PF}}+2,175 A_{\mathrm{MF}}+805 S_{\mathrm{MF}} \\
& -228 W_{\mathrm{T}}+39 L_{\mathrm{U}},
\end{aligned}
$$

where

$Q_{\mathrm{F}}=$ peak discharge at Fargo, in cubic feet per second;

$W_{\mathrm{PF}}=$ winter precipitation above Fargo, in inches, minus an arbitrary 1.7

$A_{\mathrm{MF}}=$ antecedent-moisture index above Fargo, in inches;

$S_{\mathrm{MF}}=$ snowmelt index for Fargo;

$W_{\mathrm{T}}=$ winter-temperature index;

and

$L_{\mathrm{U}}=$ land-use-index factor. 
Table 12. Hydrologic processes affecting flooding and the degree to which each process was accounted for in the regression analysis

\begin{tabular}{|c|c|c|c|c|}
\hline \multirow[t]{2}{*}{$\begin{array}{l}\text { Processes and } \\
\text { factors affecting } \\
\text { flooding processes }\end{array}$} & \multicolumn{4}{|c|}{$\begin{array}{l}\text { Degree each process was accounted } \\
\text { for in the regression analysis }\end{array}$} \\
\hline & Good & Fair & Indirect & Poor/NA \\
\hline \multicolumn{5}{|l|}{ Water availability } \\
\hline $\begin{array}{l}\text { Rainfall } \\
\text { Snowfall } \\
\text { Snowmelt }\end{array}$ & $\begin{array}{l}x \\
x\end{array}$ & & & \\
\hline $\begin{array}{l}\text { Snowpack depth } \\
\text { Snowpack density } \\
\text { Soil temperature } \\
\text { Solar radiation } \\
\text { Air temperature } \\
\text { Wind velocity } \\
\text { Long-wave radiation } \\
\text { Rainfall }\end{array}$ & $x$ & $x$ & $\begin{array}{l}x \\
x\end{array}$ & $\begin{array}{l}x \\
x \\
x \\
x\end{array}$ \\
\hline \multicolumn{5}{|l|}{ Water excess } \\
\hline \multicolumn{5}{|l|}{ Infiltration } \\
\hline $\begin{array}{l}\text { Soil condition } \\
\text { So il-moisture content } \\
\text { So il frost } \\
\text { Ground water }\end{array}$ & & & $\begin{array}{l}x \\
x\end{array}$ & $\begin{array}{l}x \\
x\end{array}$ \\
\hline Evapotranspiration & & & & $x$ \\
\hline \multicolumn{5}{|l|}{ Water routing } \\
\hline Channel flow & & & & $x$ \\
\hline $\begin{array}{l}\text { Reservoir storage } \\
\text { Depressional storage }\end{array}$ & & & $\begin{array}{l}x \\
x\end{array}$ & \\
\hline
\end{tabular}

All of the above factors were significant at the 5-percent level and the resulting coefficient of determination (often referred to as $r^{2}$ ) was 0.71 . A plot of the actual versus modeled discharges is shown in attachment $\mathrm{J} 1$.

The regression equation for the peak discharge at Grand Forks is

$$
\begin{aligned}
Q= & -20,400+3,900 W_{\mathrm{P}}+10,000 A_{\mathrm{M}}-630 W_{\mathrm{T}} \\
& +579 S_{\mathrm{M}}+0.27 P_{\mathrm{Q}}+107 L_{\mathrm{U}},
\end{aligned}
$$

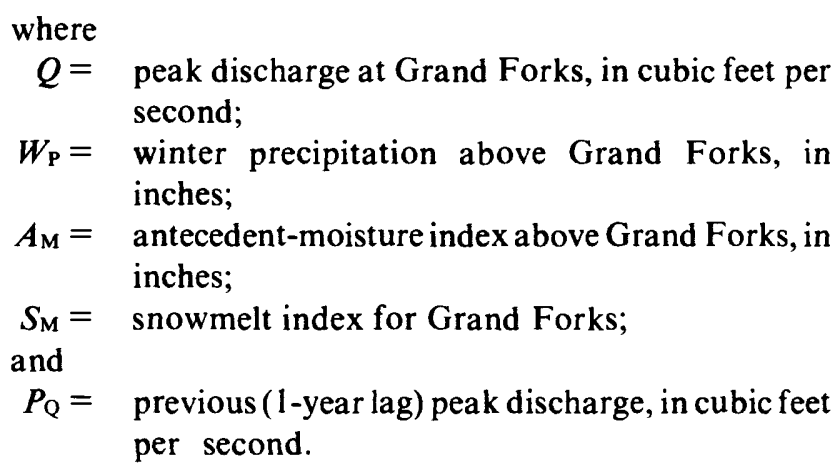

All of the above parameters were significant at the 5percent level and the coefficient of determination $\left(\mathrm{r}^{2}\right)$ for the equation was 0.87 . A plot of the actual and modeled discharges is shown in attachment $\mathbf{J} 2$.

The regression equation for the 30-day snowmelt volume at Fargo is

$$
V_{\mathrm{F}}=-120+40 W_{\mathrm{PF}}+76 A_{\mathrm{MF}}+1.2 S_{\mathrm{MF}}-6 W_{\mathrm{T}}+1 L_{\mathrm{U}},
$$

where

$V_{\mathrm{F}}=$ high 30-day snowmelt volume at Fargo in thousands of acre-feet.

All of the above parameters were significant, and the coefficient of determination for the model was 0.65 . A plot of the actual and modeled volumes is shown in attachment $\mathrm{K} 1$.

The regression equation for the 30-day high-snowmelt volume at Grand Forks is

$$
\begin{aligned}
V= & -840+202 W_{\mathrm{P}}+378 A_{\mathrm{M}}-21.7 W_{\mathrm{T}}+12 S_{\mathrm{M}} \\
& +0.47 P_{\mathrm{V}}+4 L_{\mathrm{U}},
\end{aligned}
$$

where

$V=$ high 30-day snowmelt volume at Grand Forks in thousands of acre-feet;

and

$P_{\mathrm{v}}=$ previous (1-year lag) volume.

All parameters were significant, and the coefficient of determination for the equation was 0.82 . A plot of actual versus modeled volumes is shown in attachment $\mathrm{K} 2$.

The above equations include only the variables that were significant at the 5-percent level. Several other parameters were not significant. These include (1) snowmelt precipitation, (2) the precipitation that fell between the day of the peak discharge to the end of the 30-day volume period, (3) the 1-year lag volume at Fargo, and (4) the number of days between the Fargo and Grand Forks peaks. These parameters are important; however, the data accuracy was not adequate to provide statistical significance.

Several additional models were completed in the development of the individual parameters. Although these models do not warrant inclusion in this report, a few points are noteworthy. The first model developed was a regression analysis of peak discharges at Grand Forks using individual monthly precipitation totals as the independent variables. The monthly precipitation was an average of all 15 precipitation stations. Using a stepwise regression technique, January precipitation was most highly correlated to the peak discharge. September was second, followed by November, March, December, February, August, April, May, June, October, and July. However, precipitation for January, September, November, March, and December had a significant correlation to the peak discharges, and the coefficient of determina- 
tion for these months was 0.47 . January had a coefficient of determination of 0.13 . Monthly precipitation explains only a part of the variation in peak discharges.

The second model developed was a regression analysis of peak discharge using winter precipitation at individual climatic stations as the independent variable. As was expected, data from certain stations were more closely correlated to the Grand Forks peak discharges than to other stations. Generally, the data from stations closer to the Red River (Fargo, Mayville, and Ada) were more closely correlated than data from stations near the outer basin boundaries (Devils Lake, Jamestown, Lisbon, and Redby).

The data from the most highly correlated station, Mayville, accounted for only 34 percent of the variability in Grand Forks peak discharges as compared to 47 percent for all of the stations. This indicates the importance of including several stations to develop a weighted average precipitation over the basin.

The importance of the individual climatic parameters was also tested. As expected, weighted winter precipitation at all 15 stations was the most important parameter and accounted for more than 50 percent of the total variability of peak flows. The influence or importance of each parameter in describing Grand Forks peak flows is shown in figure 17.

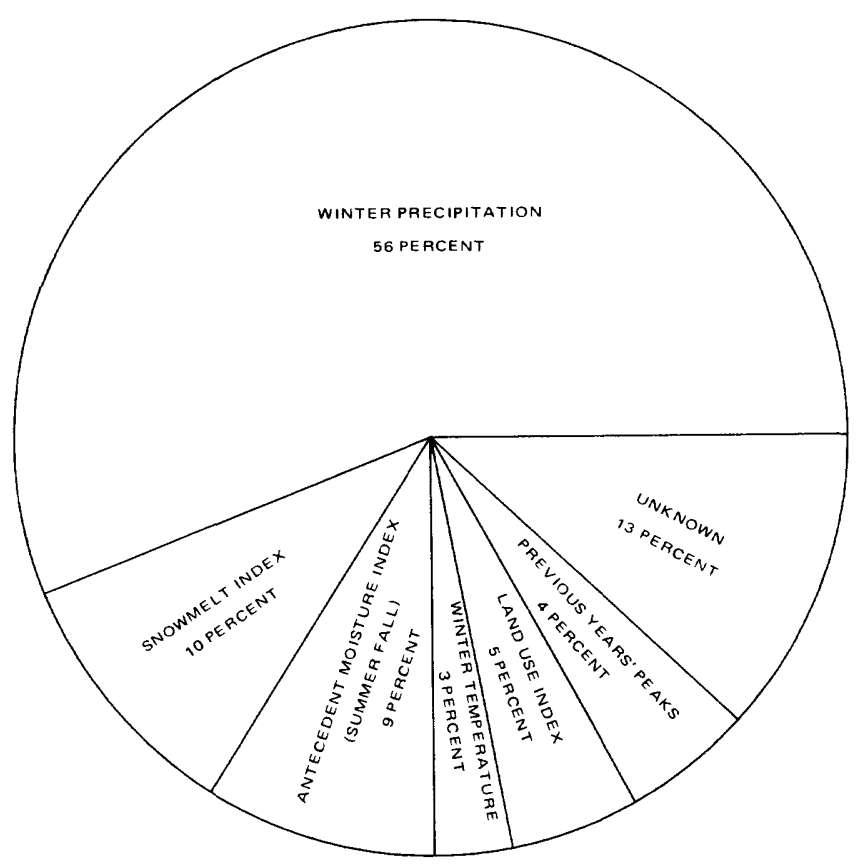

Figure 17. Percentage of the total variability in peak discharge accounted for by the individual climatic and other parameters affecting snowmelt flooding on the Red River of the North at Grand Forks.

The land-use index was a statistically significant variable in the regression analysis. This is an indication that there may have been a change in response of the basin. However, there are points of caution that need to be considered. It has been shown that during the time period studied, 1897 to 1980 , the frequency of flooding has increased in the last 30 years as compared with the previous 50 years. Almost any parameter that increased with time would likely correlate to the peak flows in the Red River. Also, drainage occurred in response to flooding impacts. Therefore, an index related to drainage would likely correlate with flooding increases. The regression analysis indicated that the flooding from 1897 to 1980 has increased beyond what can be accounted for by the climatic factors included in this study. This increase may be caused by the several factors not addressed (see table 12), or may be the result of a response to manmade influences in the Red River basin.

Due to a general lack of climatological data for the late 1800 's, only the period after 1897 was included in the regression analysis. However, it was possible to obtain some climatic data for the period between 1882 and 1897 . These data were compiled into a form that could be included in a regression analysis of Grand Forks peak discharge. The precipitation data were obtained from Simons and King (1922, table 6). This table provides average monthly precipitation for various unknown stations in the Red River basin from 1882 to 1919. Actual data from Fargo were used to develop the snowmeltindex and winter-temperature parameters. The individual parameters obtained along with actual and regressionequation-modeled peak-flow discharges for the five highest years are shown in table 13. As shown, the modeled discharges are comparable with but slightly lower than the actual peak discharges.

The land-use index remained significant when the regression analysis was rerun including the four additional years during the 1800 's. However, the importance of the land-use index decreased nearly 20 percent. It is likely that if more pre-1900 data were included, the significance of the land-use index would have been further reduced. Also, the land-use index was insignificant for the analysis that included only the data following 1950 . Therefore, it may be significant only because it is relatively large in the period following 1950 and correlates well to the large discharges. It may be representative of many other factors not accounted for in the analysis. This lack of significance of the land-use index following 1950 indicates that the $1900-50$ period possibly has different runoff characteristics than either the pre- 1900 period or the 1950-80 period. This further supports the conclusion that an adequate study of flood-response changes on the Red River must include data for floods of the late 1800's. It also indicates that, because a regression analysis cannot describe all of the complex runoff processes, a large 
Table 13. Regression parameters and recorded and modeled peak discharges for the Red River of the North floods at Grand Forks during the 1800 's

\begin{tabular}{|c|c|c|c|c|c|}
\hline & \multicolumn{5}{|c|}{ Year } \\
\hline & $1 / 1882$ & 1883 & 1892 & 1893 & $2 / 1897$ \\
\hline Recorded peak $\left(\mathrm{ft}^{3} / \mathrm{s}\right)$ & 75,000 & 38,600 & 23,000 & 53,300 & 85,000 \\
\hline Modeled peak $\left(\mathrm{ft}^{3} / \mathrm{s}\right) \underline{3} /$ & 56,300 & 35,900 & 26,400 & 54,600 & 78,400 \\
\hline Winter precipitation (inches) & 6.8 & 4.5 & 6.1 & 7.1 & 7.4 \\
\hline Antecedent-moisture index & 3.9 & 3 & 2.7 & 1.6 & 2.4 \\
\hline Winter temperatures $\left({ }^{\circ} \mathrm{F}\right)$ & 13 & 1 & 11 & 1 & 7.3 \\
\hline Snowmelt index & 20 & 5 & 10 & 56 & 87.5 \\
\hline Previous flood peak 4 / & 35,000 & 40,000 & 6,000 & 23,000 & 21,600 \\
\hline Land-use index & 0 & 0 & 0 & 0 & 0 \\
\hline
\end{tabular}

1/Data were extremely inadequate for 1882 . Most parameters

include only Fargo data.

2/1897 was the only large 1800 flood included in the regression

analysis due to climatic data availability.

3/Modeled peak discharges are from the Grand Forks peak

discharge regression equation.

4/Previous flood peak was limited to $40,000 \mathrm{ft}^{3} / \mathrm{s}$. The 1881

discharge is unknown, but high flood peaks were recorded in 1881 on the Mississippi River.

number of years of record must be analyzed. This would help to avoid the possibility of identifying a natural variation in flood flows as a change in response of the basin.

\section{SUMMARY AND CONCLUSIONS}

The review of hydrologic setting of the Red River provided both a review of the flood-response problem and an analysis problem perspective. The analysis problem perspective provides a basis for an analysis of flood response or an evaluation of the adequacy of other studies. The perspective of the problem is: hydrologically; the snowmelt-runoff processes are highly complex and not easily characterized; historically, flood discharges are highly variable; and, regionally, there is a strong indication of a regionwide pattern of variation in the wateravailability processes which account, at least in part, for the increase in flood frequency since 1950.

The flood-frequency analysis showed that flood discharges are highly variable on the Red River. It provided additional evidence for the regionwide pattern of variation in water-availability processes since 1950 . Finally, it showed that the flood frequency during the late 1800 's is similar to the flood frequency experienced since
1950 on the Red River. The analysis indicates that an adequate study of the flood-response changes on the Red River must include data for the floods of the late 1800's.

The normalized-hydrograph analysis did not provide an indication of response change. The results did not show a large variation between the two periods or a variation consistent with what would be expected if a response change had actually occurred. The analysis was severely limited because mean daily discharge data from the late 1800 's were not available.

The double-mass analysis was shown to be inadequate for evaluating response changes of the Red River. However, it did provide additional evidence that flooddischarge characteristics of the late 1800's were similar to those since 1950. This, again, indicates that an adequate analysis of flood-response changes on the Red River must include data for the floods of the late 1800's.

The regression analysis for the period 1897 to 1980 indicated that the land-use index was significant. However, the analysis also showed that as more data from the late 1800's were included in the analysis the land-use index became less significant. Also, if the period following 1950 is used, the land-use index is not significant. This, again, indicates that the period 1900 to 1950 does not provide an adequate base for the analysis and that the 
late 1800 's should be included in an adequate analysis. Because a regression analysis cannot describe all of the complex runoff processes, a large number of years of record must be analyzed to avoid the possibility of identifying a natural variation in flood flows as a change in response. The regression analysis indicated that flooding has increased from 1897 to 1980 beyond what can be accounted for by the climatic factors included in this study. This increase may be caused by the several factors not addressed, or the increase may be the result of a response to manmade influences in the Red River basin.

Because of the complexity of the runoff problem, the historical variation, and the regionwide pattern of variation in runoff, little indication of significant change in flood response of the Red River basin were evident on the main stem. The large floods that have occurred since 1950 do not indicate a change in flood response of the basin. However, the large variation in flood discharges may mask or dwarf small changes in response of the basin.

\section{ADDITIONAL STUDIES}

As a result of this study, the need for further work in a number of areas has become apparent. Work in each of these areas will provide additional information on the hydrologically complex and historically variable Red River response-change problem. The areas for which further work is needed include the development of hydrologic and hydraulic data, hydrologic-processes research, flow-routing tools, historical information, and streamflow-gaging methods.

\section{Hydrologic and Hydraulic Data}

The development of hydrologic and hydraulic data on the subbasins of the Red River basin is still lacking at this time. The data development required includes drainage areas, land-use characteristics, stream-channel-hydraulic characteristics, and long-term climatological data in digital form. These data form a basis for most detailed basin analyses. Because of the flatness of most of the subbasins and the many noncontributing and partly contributing areas in the basin, many of these data are difficult to develop.

A reasonable approach to the drainage-area-determination problem is needed. It may include a development of drainage-area-frequency curves to relate the contributing drainage area to the magnitude of the runoff event. This is a difficult problem because runoff events are caused by both rainfall and snowmelt, which may have to be evaluated separately. Although the problem is difficult, an approach is needed. Some consistent proce- dure of determination must be followed to make the data available.

A determination of the land-use characteristics and changes in the basin is needed. This is a large-scale problem that is constantly changing. Some characterization of land use in the basin is needed to evaluate the hydrologic effects of future changes.

Stream-channel-hydraulic characteristics such as channel geometry, river miles, channel slopes, and roughness coefficients must be developed for input to flowrouting models. These data are needed to evaluate the effects of the water-routing processes. Flood studies that include detailed step-backwater analyses to determine flood profiles can provide these kinds of data. Additional flood studies and other detailed evaluations of streamhydraulic characteristics are needed.

Climatological data in digital form are needed for evaluating flooding prior to significant land-use changes. There are considerable climatological data available at many locations in many forms for long periods of record. These data need to be compiled, checked for consistency, and made available in a convenient digital form.

\section{Hydrologic-Processes Research}

Until the complex hydrologic processes that control the magnitude of runoff in the Red River basin are understood, the effects of drainage and other land-use changes on runoff characteristics cannot be determined. The evaluation of hydrologic processes is a detailed and complex study. Therefore, longer term research is needed on this topic. This will provide a basis for the development and testing of detailed hydrologic models. A model that explicitly represents all of the important processes that determine the runoff characteristics of the basin is needed to evaluate the flood-response-change problem. Because of the complexity of detailed hydrologic-processes models, a model of the entire basin is probably not a reasonable approach. Instead, detailed models of subbasins could be developed to describe the effects of land-use changes in different areas of the basin.

The relatively flat Red River basin with its many depressional storages does not readily lend itself to evaluation based on the typical hydrologic concepts on which most watershed models are based. Instead, detailed data collection and analysis of runoff characteristics of a number of small basins in the Red River basin are needed. The critical hydrologic period that controls floods on the Red River is the snowmelt-runoff period. The analysis should emphasize this period. In analyzing the runoff processes involved in the snowmelt-runoff period, the importance of each process listed in table 8 needs to be evaluated. The dynamics of each important 
process can then be determined. The many items that should be evaluated include infiltration rates for frozen soil during the melt period, the importance of groundwater flow, the hydraulic characteristics of overland flow, and the snowmelt process in this flat basin with little cover. The changes due to the hydraulic characteristics of the manmade drainage channels need to be explicitly understood so that they can be included in the model.

A watershed model that explicitly represents the controlling processes in the basins need to be developed following this analysis. This model would then be used to determine changes in runoff due to drainage or other land-use changes on small basins. To evaluate the overall effect of these small basins on the Red River main-stem floods, a flow-routing model of the basin would be required.

\section{Flow-Routing Tools}

Changes in flow in upper reaches of the stream system are often significantly attenuated and dispersed by the channel-storage and dynamic effects of the flowrouting processes. Hydraulic flow models based on the diffusion wave (or diffusion analogy) or the full-dynamicwave theory describing one-dimensional unsteady openchannel flow would provide the capability of describing the channel-flow-routing processes. Simpler models, not based on the theory of unsteady open-channel flow, cannot provide predictions for changes in flow outside the range of flows for which the models are tested. Flowrouting tools that can evaluate the storage and dynamic effects of the flow-routing processes are needed to evaluate the downstream impacts of runoff changes on small basins upstream.

\section{Historical Information}

A detailed evaluation of historical flood information would provide an improved understanding of the variation with time of flood discharges and provide an improved flood-frequency analysis on which to base the design of flood-related structures. Historical research could provide additional information on the magnitude of the floods listed in table 8 and possibly find information on additional floods not found in this study. More importantly, a careful evaluation and inspection of the hydraulic data available for the historical floods could lead to the development of discharge data based on U.S. Geological Survey procedures for determining peak discharges by indirect methods (Benson and Dalrymple, 1968). These discharge data would provide improved floodfrequency information if adequate hydraulic data were developed. A detailed evaluation of historical flood information is needed to provide an improved understanding of the variation in flood discharges with time and improved flood-frequency information.

\section{Streamflow-Gaging Methods}

The analysis of changes in flood response is hampered, to some extent, by the difficulty of obtaining accurate peak-discharge data on the Red River. Because of the flatness of the main stem, there is no single valued rating curve for relating stage to discharge. Instead, discharge measurements must be obtained at fairly short intervals to define the loop rating for each flood. While this may not have much impact on the peak-discharge values alone, it can have a significant impact on the flow volumes measured over the entire flood hydrograph.

Numerous improved methods could be investigated. For example, the development of unsteady-flow models, based on boundary conditions at two gaging stations in one reach of the Red River, could provide a definition of the loop rating. Also, the installation of acoustic velocity meters may provide this definition. These methods may improve the discharge data and allow a less frequent direct measurement of discharges during peak-flow periods. Improved methods of gaging both low and peak flows on the rivers of flat slope in eastern North Dakota need to be investigated and developed.

\section{REFERENCES CITED}

Arndt, B. M., 1975, Geology of Cavalier and Pembina Counties: North Dakota Geological Survey Bulletin 62, pt. I, and North Dakota State Water Commission County Ground-Water Studies 20, pt. I, 68 p.

Augustadt, W. W., 1955, Drainage in the Red River Valley of the North: U.S. Department of Agriculture Yearbook of Agriculture 1955, p. 569-576.

Baker, C. H., Jr., 1967, Geology and ground-water resources of Richland County: North Dakota Geological Survey Bulletin 46, pt. I, and North Dakota State Water Commission County Ground-Water Studies 7, pt. I, 45 p.

Banga, A. B., 1978, Flood peak potential at Moose Jaw: Canada-Saskatchewan Flood Damage Reduction Program Report No. HYD-5-47, Saskatchewan Department of the Environment, $36 \mathrm{p}$.

Bavendick, F. J., 1952, Climate and weather in North Dakota: North Dakota State Water Commission, 126 p.

1959, The climate of North Dakota, in Climates of the states, Volume II-Western states (including Alaska and Hawaii): National Oceanic and Atmospheric Administration, U.S. Department of Commerce, p. 811-825.

Benson, M. A., 1960, Characteristics of frequency curves based on a theoretical 1,000-year record, in Dalrymple, Tate, 
Flood-frequency analyses, Manual of Hydrology, pt. 3, Flood-flow techniques: U.S. Geological Survey WaterSupply Paper 1543-A, p. 51-77.

Benson, M. A., and Dalrymple, Tate, 1968, General field and office procedures for indirect discharge measurements: Techniques of Water Resources Investigations of the United States Geological Survey, Chapter Al, Book 3, 30 p.

Bidwell, L. F., Winters, T. C., and Maclay, R. W., 1970, Water resources of the Red Lake River watershed, northwestern Minnesota: U.S. Geological Survey Hydrologic Investigations Atlas HA-346, 4 sheets.

Bluemle, John, 1980, Talk on flooding along the Red River of the North (Before the Lower Sheyenne River Citizens Committee at Kindred, North Dakota): April 14, 1980 , $6 \mathrm{p}$.

Campbell, K.L., and Johnson, H.P., 1975, Hydrologic simulation of watersheds with artificial drainage: Water Resources Research, v. 11, no. 1, p. 120-126.

Canada Department of Resources and Development, 1953, Report on investigations into measures for the reduction of the flood hazard in the greater Winnipeg area: Prepared by the Red River Basin Investigation, Water Resources Division, Engineering and Water Resources Branch, 66 p., 8 appendices.

Carlson, C. G., 1973, Generalized bedrock geologic map of North Dakota: North Dakota Geological Survey Miscellaneous Map 16, 1 sheet.

Carlson, C. G., and Freers, T. F., 1975, Geology of Benson and Pierce Counties, North Dakota: North Dakota Geological Survey Bulletin 59, pt. I, and North Dakota State Water Commission County Ground-Water Studies 18, pt. I, 32 p.

Carlston, C. W., 1963, Drainage density and streamflow: U.S. Geological Survey Professional Paper 422-C, 8 p.

Conger, D. H., 1971, Estimating magnitude and frequency of floods in Wisconsin: U.S. Geological Survey Open-File Report, 200 p.

Dalrymple, Tate, 1960, Flood-frequency analyses, Manual of Hydrology, part 3, Flood-flow techniques: U.S. Geological Survey Water-Supply Paper 1543-A, 79 p.

Dingman, S. L., 1978, Drainage density and streamflow: A closer look: Water Resources Research, v. 14, no. 6, p. 1183-1187.

Drache, H. M., 1970, The challenge of the prairie: Life and times of Red River pioneers: North Dakota Institute for Regional Studies, Fargo, 360 p.

Draper, D. W., 1973, R oseau River hydrologic modelling: Water Planning and Management Service, Environmental Management Service, Environment Canada, 55 p.

Eagleson, P. S., 1970, Dynamic hydrology: New York, McGraw-Hill Book Company, 462 p.

Eisenlohr, W. S., Jr., and others, 1972, Hydrologic investigations of prairie potholes in North Dakota, 1959-68: U.S. Geological Survey Professional Paper 585-A, 102 p.

Fenneman, N. M., 1931, Physiography of western United States: New York, McGraw-Hill Book Company, 534 p.

Hammen, J. L., 1980, Affects of agricultural drainage on flooding in the Red River basin: M.A. Thesis, University of North Dakota, Grand Forks, 113 p.

Hansen, D. E., and Kume, Jack, 1970, Geology and ground- water resources of Grand Forks County: North Dakota Geological Survey Bulletin 53, pt. 1, and North Dakota State Water Commission County Ground-Water Studies 13, pt. I, 76 p.

Hard, H. A., 1921, Report to the Governor of North Dakota on flood control, Administrative report: Grand Forks, North Dakota, Normanden Publishing Company, State Printers, $126 \mathrm{p}$.

Harrison, S. S., and Bluemle, J. P., 1980, Flooding in the Grand Forks-East Grand Forks area: North Dakota Geological Survey Educational Series 12, 64 p.

Jarvis, C. A., and others, 1936, Floods in the United States, Magnitude and frequency: U.S. Geological Survey WaterSupply Paper 771, 497 p.

Kelly, T. E., and Block, D. A., 1967, Geology and groundwater resources, Barnes County, North Dakota: North Dakota Geological Survey Bulletin 43, pt. 1, and North Dakota State Water Commission County Ground-Water Studies 4, pt. 1,51 p.

Leitch, J. A., 1980, Wetland hydrology: State-of-the-art and annotated bibliography: North Dakota Water Resources Research Institute and Department of Agricultural Economics, North Dakota Agricultural Experiment Station, North Dakota State University, Fargo, 40 p.

Linsley, R. K., and Franzini, J. B., 1972, Water-resources engineering (2d ed.): New York, McGraw-Hill Book Company, $690 \mathrm{p}$.

Mahood, H. E., 1977, Hydrologic effect of drainage development in the upper Souris basin: Saskatchewan Department of the Environment, Hydrology Branch, Report HYD-1-17, 31 p.

Moore, 1. D., and Larson, C. L., 1979, Effects of drainage projects on surface runoff from small depressional watersheds in the north-central region: University of Minnesota, Water Resources Research Center Bulletin 99, 225 p.

North Dakota State Water Commission and Minnesota Department of Natural Resources Division of Waters, Soils, and Minerals, 1971, Red River of the North regional flood analysis (Breckenridge to international boundary): $\mathbf{p}$. 18-19.

Paul, G. L., and Verry, E. S., 1980, Changes in water yield resulting from changes in land use; For March 27-28, 1980 , Symposium, North country futures, Industrial impacts on forest resources, communities, and you: Bemidji State University, Bemidji, Minnesota, 11 p.

Paulhus, J. L. H., 1971, The March-April 1969 snowmelt floods in the Red River of the North, upper Mississippi, and Missouri basins: National Oceanic and Atmospheric Administration, National Weather Service, NOAA Technical Report NWS 13, 92 p.

Pentland, R. S., 1980, Agricultural drainage impacts in Saskatchewan (discussion paper): Hydrology Branch, Saskatchewan Environment, 15 p.

Rannie, W. F., 1980, The Red River flood control system and recent flood events: Water $R$ esources Bulletin, v. 16, no. 2 , Paper No. 79022, p. 207-214.

Red River Modeling Task Force, 1981, Red River of the North modeling evaluation: The International Souris-Red Rivers Engineering Board, September 1981, 38 p. 
SAS Institute, Inc., 1979, Statistical analysis system, SAS user's guide: Raleigh, North Carolina, 494 p.

Searcy, J. K., and Hardison, C. H., 1960, Double-mass curves-Manual of hydrology: Part I, General surfacewater techniques: U.S. Geological Survey Water-Supply Paper 1541-B, 66 p.

Simons, P. T., and King, F. V., 1922, Report on drainage and prevention of overflow in the valley of the Red River of the North: U.S. Department of Agriculture Bulletin No. 1017, 89 p.

Sloan, C. E., 1970, Prairie potholes and the water table: U.S. Geological Survey Professional Paper 700-B, p. B227B231.

Souris-Red-Rainy River Basin Commission, 1972a, SourisRed-Rainy basins comprehensive study-Flood damage reduction and drainage, volume 1: $344 \mathrm{p}$.

1972b, Souris-Red-Rainy basins comprehensive studyFlood damage reduction and drainage, volume 3, 205 p.

Stewart, J. T., 1907, Report on the drainage of the eastern parts of Cass, Traill, Grand Forks, Walsh, and Pembina Counties, North Dakota: U.S. Department of Agriculture, Office of Experiment Stations, Bulletin 189, 71 p.

Strahler, A. N., 1964, Part II-Quantitative geomorphology of drainage basins and channel network: Handbook of Applied Hydrology, New York, McGraw-Hill Book Company, p. 4-39 to 4-76.

U.S. Army Corps of Engineers, 1956a, Review of report on flood control and related problems, Red River of the North drainage basin, Minnesota, South Dakota, and North Dakota: St. Paul District, St. Paul, Minnesota, $34 \mathrm{p}$. 1956b, Snow hydrology: Portland, Oregon, $437 \mathrm{p}$. 1960, Runoff from snowmelt: EM III0-2-1406, Manuals, Engineering and Design, $75 \mathrm{p}$.

1973, Interim survey, Park River, North Dakota, Red River of the North basin for flood control and related purposes: St. Paul District, St. Paul, Minnesota, 49 p. 1977, Red River of the North, Main stem, Hydrologic data: St. Paul District, St. Paul, Minnesota, 36 p. 1978, Interim feasibility study, Red River of the North, Main stem: St. Paul District, St. Paul, Minnesota, 138 p.
1979, Phase 1-Analysis of existing hydrologic models, Red River of the North drainage basin, North Dakota and Minnesota: St. Paul District, St. Paul, Minnesota, 13 p.

1980a, Phase II-Analysis of existing hydrologic models, Red River of the North drainage basin, North Dakota and Minnesota: St. Paul District, St. Paul, Minnesota, 29 p.

1980 b, Reconnaissance report, Flood control study for Rush River and lower branch Rush River, North Dakota: St. Paul District, St. Paul, Minnesota, 25 p.

U.S. Department of Commerce, 1954, Floods of 1952, Upper Mississippi-Missouri-Red River of the North: Hydrologic Services Division, Technical Paper No. 23, 93 p.

1962, Snowmelt floods of March-April 1960, Missouri and upper Mississippi basins: Hydrologic Services Division, River Services Section, Technical Paper No. 45, 77 p. 1973, Monthly normals of temperature, precipitation, and heating and cooling degree days, 1941-1970: Environmental Data Service, National Oceanic and Atmospheric Administration Climatography of the United States, No. 81 (by State), North Dakota.

1977, Climatic atlas of the United States: Environmental Science Services Administration, Environmental Data Service, 80 p.

U.S. Geological Survey, 1952, Floods of 1950 in the Red River of the North and Winnipeg River basins: U.S. Geological Survey Water-Supply Paper 1137-B, 325 p.

U.S. Water Resources Council, 1977, Guidelines for determining flood flow frequency: Hydrology Committee Bulletin $17 \mathrm{~A}, 26 \mathrm{p}$.

Upham, Warren, 1895, The glacial Lake Agassiz: U.S. Geological Survey Monograph, v. XXV, 658 p.

Upper Mississippi River Basin Commission, 1979, Proposal to study Red River basin surface drainage systems, Management special study, June 1979: 27 p.

Wilcock, D. N., 1979, Post-war land drainage, fertilizer use, and environmental impact in northern Ireland: Journal of Environmental Management, v. 8, no. 2, p. 137-149.

Wilde, Lorne, 1945, Drainage in the Red River Valley: Fargo Forum, Forum Publishing Company, Fargo, North Dakota, 14 p. 


\section{SELECTED FACTORS FOR CONVERTING INCH-POUND UNITS TO THE INTERNATIONAL SYSTEM OF UNITS (SI)}

For those readers who may prefer to use the International System of units rather than inch-pound units, the conversion factors for the terms used in this report are given below.

\begin{tabular}{rrl}
\hline \multicolumn{1}{r}{ Multiply inch-pound unit } & By & \multicolumn{1}{c}{ To obtain SI unit } \\
acre & 0.4047 & hectare $(\mathrm{ha})$ \\
cubic foot per second $\left(\mathrm{ft}^{3} / \mathrm{s}\right)$ & 0.02832 & cubic meter per second $\left(\mathrm{m}^{3} / \mathrm{s}\right)$ \\
cubic foot per second $\left(\mathrm{ft}^{3} / \mathrm{s}\right)$ & 28.32 & liter per second $(\mathrm{L} / \mathrm{s})$ \\
foot $(\mathrm{ft})$ & 0.3048 & meter $(\mathrm{m})$ \\
foot per mile $(\mathrm{ft} / \mathrm{mi})$ & 0.1894 & meter per kilometer $(\mathrm{m} / \mathrm{km})$ \\
inch $(\mathrm{in})$. & 25.40 & millimeter $(\mathrm{mm})$ \\
langley $(\mathrm{ly})$ & $41,840.0$ & joule per square meter $\left(\mathrm{J} / \mathrm{m}^{2}\right)$ \\
mile $(\mathrm{mi})$ & 1.609 & kilometer $(\mathrm{km})$ \\
square mile $\left(\mathrm{mi}^{2}\right)$ & 2.590 & square kilometer $\left(\mathrm{km}^{2}\right)$
\end{tabular}

To convert degrees Fahrenheit $\left({ }^{\circ} \mathrm{F}\right)$ to degrees Celsius $\left({ }^{\circ} \mathrm{C}\right)$ use the following formula: ${ }^{\circ} \mathrm{C}=\left({ }^{\circ} \mathrm{F}-32\right) \times 5 / 9$.

National Geodetic Vertical Datum of 1929 (NGVD of 1929): A geodetic datum derived from a general adjustment of the first-order nets of both the United States and Canada, formerly called mean sea level. 
Attachment A. Listing of streamflow stations and their corresponding period of record for the Red River of the North Basin in North Dakota and Minnesota

\begin{tabular}{cc} 
Downstream \\
$\begin{array}{c}\text { order number } \\
\text { Name of station }\end{array}$ & $\begin{array}{c}\text { Period of record } \\
\text { (continuous to } \\
\text { present unless } \\
\text { otherwise } \\
\text { specified) }\end{array}$ \\
\hline
\end{tabular}

\begin{tabular}{|c|c|c|}
\hline \multicolumn{3}{|c|}{ NORTH DAKOTA } \\
\hline $\begin{array}{l}05050000 \\
05050500 \\
05051500 \\
05051522 \\
05051600 \\
05053000\end{array}$ & $\begin{array}{l}\text { Bois de Sioux River near White Rock, S. Dak. } \\
\text { Bois de Sioux River below Fairmont } \\
\text { Red River of the North at Wahpeton } \\
\text { Red River of the North near Hickson } \\
\text { Wild Rice River near Rutland } \\
\text { Wild Rice River near Abercrombie }\end{array}$ & $\begin{array}{l}1941 \\
1919-44 \\
1942 \\
1975 \\
1959 \\
1932\end{array}$ \\
\hline $\begin{array}{l}05054000 \\
05054500 \\
05056000 \\
05056100 \\
05056200 \\
05056239\end{array}$ & $\begin{array}{l}\text { Red River of the North at Fargo } \\
\text { Sheyenne River above Harvey } \\
\text { Sheyenne River near Warwick } \\
\text { Mauvais Coulee near Cando } \\
\text { Edmore Coulee near Edmore } \\
\text { Starkweather Coulee near Webster }\end{array}$ & $\begin{array}{l}1901 \\
1955 \\
1949 \\
1956 \\
1956 \\
1979\end{array}$ \\
\hline $\begin{array}{l}05056390 \\
05056400 \\
05057000 \\
05057200 \\
05058000 \\
05058700\end{array}$ & $\begin{array}{l}\text { Little Coulee near Brinsmade } \\
\text { Big Coulee near Churchs Ferry } \\
\text { Sheyenne River near Cooperstown } \\
\text { Baldhill Creek near Dazey } \\
\text { Sheyenne River below Baldhill Dam } \\
\text { Sheyenne River at Lisbon }\end{array}$ & $\begin{array}{l}1975 \\
1950 \\
1944 \\
1956 \\
1949 \\
1956\end{array}$ \\
\hline $\begin{array}{l}05059000 \\
05059500 \\
05059600 \\
05059700 \\
05060000 \\
05060500\end{array}$ & $\begin{array}{l}\text { Sheyenne River near Kindred } \\
\text { Sheyenne River at West Fargo } \\
\text { Maple River near Hope } \\
\text { Maple River near Enderlin } \\
\text { Maple River near Mapleton } \\
\text { Rush River at Amenia }\end{array}$ & $\begin{array}{l}1949 \\
1902,1903-05 \\
1964 \\
1956 \\
1944-75 \\
1946\end{array}$ \\
\hline $\begin{array}{l}05064900 \\
05066500 \\
05082500 \\
05083000 \\
05083600 \\
05084000\end{array}$ & $\begin{array}{l}\text { Beaver Creek near Finley } \\
\text { Goose River at Hillsboro } \\
\text { Red River of the North at Grand Forks } \\
\text { Turtle River at Manvel } \\
\text { Middle Branch Forest River near Whitman } \\
\text { Forest River near Fordville }\end{array}$ & $\begin{array}{l}1964 \\
1931 \\
1882 \\
1945-70 \\
1960 \\
1940\end{array}$ \\
\hline
\end{tabular}




\begin{tabular}{cc}
\hline & $\begin{array}{c}\text { Period of record } \\
\text { (continuous to } \\
\text { pownstream } \\
\text { order number }\end{array}$ \\
otherwise \\
specified)
\end{tabular}

NORTH DAKOTA, Continued

\begin{tabular}{|c|c|c|}
\hline $\begin{array}{l}05085000 \\
05089000 \\
05089100 \\
05089500 \\
05090000 \\
05092000\end{array}$ & $\begin{array}{l}\text { Forest River at Minto } \\
\text { South Branch Park River below Homme Dam } \\
\text { Middle Branch Park River near Union } \\
\text { Cart Creek at Mountain } \\
\text { Park River at Grafton } \\
\text { Red River of the North at Drayton }\end{array}$ & $\begin{array}{l}1944 \\
1949 \\
1965 \\
1954 \\
1931 \\
1936-37,1941\end{array}$ \\
\hline $\begin{array}{l}05092200 \\
05098700 \\
05098800 \\
05099100 \\
05099150 \\
05099300\end{array}$ & $\begin{array}{l}\text { Pembina County drain } 20 \text { near Glasston } \\
\text { Hidden Is land Coulee near Hansboro } \\
\text { Cypress Creek near Sarles } \\
\text { Snowflake Creek near Snowflake, Manitoba } \\
\text { Mowbray Creek near Mowbray, Manitoba } \\
\text { Pembina River near Windygates, Manitoba }\end{array}$ & $\begin{array}{l}1971 \\
1961 \\
1961 \\
1961 \\
1962 \\
1962\end{array}$ \\
\hline $\begin{array}{l}05099400 \\
05099600 \\
05100000\end{array}$ & $\begin{array}{l}\text { Little South Pembina River near Walhalla } \\
\text { Pembina River at Walhalla } \\
\text { Pembina River at Neche }\end{array}$ & $\begin{array}{l}1956 \\
1939 \\
1903-08,1909-15, \\
1919\end{array}$ \\
\hline $\begin{array}{l}05101000 \\
05102500\end{array}$ & $\begin{array}{l}\text { Tongue River at Akra } \\
\text { Red River of the North at Emerson, Manitoba }\end{array}$ & $\begin{array}{l}1950,1951 \\
1902,1912\end{array}$ \\
\hline 05113360 & $\begin{array}{l}\text { Long Creek at western crossing of } \\
\text { international boundary, Saskatchewan }\end{array}$ & 1959 \\
\hline $\begin{array}{l}05113600 \\
05113700 \\
05113800\end{array}$ & $\begin{array}{l}\text { Long Creek near Noonan } \\
\text { West Branch Short Creek near Columbus } \\
\text { Short Creek below international boundary } \\
\text { near Roche Percee, Saskatchewan }\end{array}$ & $\begin{array}{l}1959 \\
1977 \\
1960\end{array}$ \\
\hline $\begin{array}{l}05114000 \\
05116000 \\
05116500 \\
05117500 \\
05120000 \\
05120500\end{array}$ & $\begin{array}{l}\text { Souris River near Sherwood } \\
\text { Souris River near Foxholm } \\
\text { Des Lacs River at Foxholm } \\
\text { Souris River above Minot } \\
\text { Souris River near Verendrye } \\
\text { Wintering River near Karls ruhe }\end{array}$ & $\begin{array}{l}1930 \\
1904-06,1936 \\
1904-06,1945 \\
1903 \\
1933,1937 \\
1937\end{array}$ \\
\hline
\end{tabular}


Downst ream

order number
Name of station
Period of Record

(continuous to

present unless

otherwise

specified)
NORTH DAKOTA, Cont inued

05122000

05123100

05123400

05123600

05123900

05124000

Souris River near Bantry

Oak Creek at Lake Metigoshe near Bottineau

Willow Creek near Willow City

Egg Creek near Granville

Boundary Creek near Landa

Souris River near Westhope

\section{MINNESOTA}

05030000

05030500

05033900

05034000

05034100

05035500

05035600

05037100

05040500

05045950

05046000

05047500

05048000

05048500

05049000

05051000

05054020

05061000

05061500

05062000

05062500
Ottertail River near Detroit Lakes

Ottertail River at German Church

Pelican River at Detroit Lakes

Pelican River near Detroit Lakes outlet

Pelican River at Detroit Lakes outlet

St. Clair outlet near Detroit Lakes

Pelican River at Muskrat Lake outlet

Pelican River at Sattie Lake outlet

Pelican River near Fergus Falls

Orwell Lake near Fergus Falls

Ottertail River near Fergus Falls

Mustinka ditch above West Mustinka River

Mustinka ditch below West Branch Mustinka River

West Branch Mustinka River (12 Mile Creek

below Mustinka Ditch near Charlesville

Mustinka River above Wheaton

Babbitt Creek at Campbell

Red River of the North below Fargo, N. Dak.

Buffalo River near Hawley

South Branch Buffalo River at Sabin

Buffalo River near Dilworth

Wild Rice River at Twin Valley
1937

1953

1956

1956

1957

1929,1930
$1937-71$

1904-17

$1968-71,1975$

$1942-53$

$1968-71,1973-75$

1968-75

1968-75

$1969-75$

1909-12, 1949

1953

1930

1943-55

1943-55

1943-55

1916-24, 1931, 1958

1943-51

1969-78

1945

1945

1931

1909-17, 1930 


\begin{tabular}{|c|c|c|}
\hline $\begin{array}{l}\text { Downs tream } \\
\text { order number }\end{array}$ & Name of station & $\begin{array}{l}\text { Period of record } \\
\text { (continuous to } \\
\text { present unless } \\
\text { otherwise } \\
\text { specified) }\end{array}$ \\
\hline \multicolumn{3}{|c|}{ MINNESOTA, Continued } \\
\hline $\begin{array}{l}05063000 \\
05063500 \\
05064000 \\
05064500 \\
05067000\end{array}$ & $\begin{array}{l}\text { Wild Rice River near Ada } \\
\text { South Branch Wild Rice River near Borup } \\
\text { Wild Rice River at Hendrum } \\
\text { Red River of the North at Halstad } \\
\text { Marsh River below Ada }\end{array}$ & $\begin{array}{l}1948-54 \\
1944-49 \\
1944 \\
1936-37,1942-60 \\
1961 \\
1948-52\end{array}$ \\
\hline $\begin{array}{l}05067500 \\
05068000 \\
05068500 \\
05069000 \\
05074000 \\
05074500\end{array}$ & $\begin{array}{l}\text { Marsh River near Shelly } \\
\text { Sand Hill River at Beltraml } \\
\text { Sand Hill ditch at Beltrami } \\
\text { Sand Hill River at Climax } \\
\text { Lower Red Lake near Red Lake } \\
\text { Red Lake River near Red Lake }\end{array}$ & $\begin{array}{l}1944 \\
1943-58 \\
1943-58 \\
1943 \\
1930-32,1933 \\
1933\end{array}$ \\
\hline $\begin{array}{l}05075000 \\
05076000 \\
05076500 \\
05077000 \\
05077500\end{array}$ & $\begin{array}{l}\text { Red Lake River at High Landing near Goodridge } \\
\text { Thief River near Thief River Falls } \\
\text { Red Lake River at Thief River Falls } \\
\text { Clearwater River near Pinewood } \\
\text { Clearwater River near Leonard }\end{array}$ & $\begin{array}{l}1929 \\
1909-17,1920-21 \\
1923-24,1929 \\
1909-18,1920-30 \\
1940-45 \\
1934-47\end{array}$ \\
\hline $\begin{array}{l}05077700 \\
05078000 \\
05078230 \\
05078500 \\
05079000 \\
05083500\end{array}$ & $\begin{array}{l}\text { Ruffy Brook near Gonvick } \\
\text { Clearwater River at Plummer } \\
\text { Lost River at Oklee } \\
\text { Clearwater River at Red Lake Falls } \\
\text { Red Lake River at Crookston } \\
\text { Red River of the North at Oslo }\end{array}$ & $\begin{array}{l}1960-78 \\
1939-79 \\
1960 \\
1909-17,1935 \\
1901 \\
1973-78\end{array}$ \\
\hline $\begin{array}{l}05085500 \\
05087500 \\
05092500 \\
05093000 \\
05094000\end{array}$ & $\begin{array}{l}\text { Snake River at Warren } \\
\text { Middle River at Arygle } \\
\text { Two Rivers near Hallock } \\
\text { South Branch Two Rivers at Pelan } \\
\text { South Branch Two Rivers at Lake Bronson }\end{array}$ & $\begin{array}{l}1945,1954-56 \\
1945,1951 \\
1931-38 \\
1928-38,1954-57 \\
1929-37,1941-47 \\
1954\end{array}$ \\
\hline
\end{tabular}




\begin{tabular}{cc}
\hline $\begin{array}{c}\text { Downstream } \\
\text { order number }\end{array}$ & $\begin{array}{c}\text { Period of record } \\
\text { (continuous to } \\
\text { present unless } \\
\text { otherwise } \\
\text { specified) }\end{array}$ \\
\hline
\end{tabular}

\begin{tabular}{|c|c|c|}
\hline \multicolumn{3}{|c|}{ MINNESOTA, Continued } \\
\hline $\begin{array}{l}05095000 \\
05095500 \\
05096000 \\
05096500\end{array}$ & $\begin{array}{l}\text { South Branch Two Rivers at Hallock } \\
\text { Two Rivers below Hallock } \\
\text { North Branch Two Rivers near Lancaster } \\
\text { State Ditch No. } 85 \text { near Lancaster }\end{array}$ & $\begin{array}{l}1911-14,1929-30, \\
1941-43 \\
1945-55 \\
1929-38,1941-55 \\
1929-38,1942 \\
1955\end{array}$ \\
\hline $\begin{array}{l}05097000 \\
05097500 \\
05103000 \\
05104000 \\
05104500\end{array}$ & $\begin{array}{l}\text { North Branch Two Rivers at Lancaster } \\
\text { North Branch Two Rivers at Northcote } \\
\text { Roseau River near Malung } \\
\text { South Fork Roseau River near Malung } \\
\text { Roseau River below South Fork near Malung }\end{array}$ & $\begin{array}{l}1941-42,1954-56 \\
1941-42,1945-52 \\
1928-46 \\
1911-14,1928 \\
1946 \\
1946\end{array}$ \\
\hline $\begin{array}{l}05105000 \\
05105300 \\
05106000 \\
05106500 \\
05107000 \\
05107500\end{array}$ & $\begin{array}{l}\text { Roseau River at Roseau } \\
\text { Roseau River bel ow Roseau } \\
\text { Sprague Creek near Sprague } \\
\text { Roseau River at Roseau Lake } \\
\text { Pine Creek near Pine Creek } \\
\text { Roseau River at Ross }\end{array}$ & $\begin{array}{l}1940-47 \\
1973 \\
1929 \\
1939 \\
1928-53 \\
1928\end{array}$ \\
\hline $\begin{array}{l}05108000 \\
05108500 \\
05109000 \\
05109500 \\
05110500\end{array}$ & $\begin{array}{l}\text { Roseau River near Badger } \\
\text { Roseau River near Duxby } \\
\text { Badger Creek near Badger } \\
\text { Roseau River near Haug } \\
\text { Roseau River at head of Ditch No. } 51 \text { near } \\
\text { Oak Point }\end{array}$ & $\begin{array}{l}1928-69 \\
1929-51 \\
1929-30,1932-38 \\
1932-66 \\
1933-42\end{array}$ \\
\hline $\begin{array}{l}05111000 \\
05112000\end{array}$ & $\begin{array}{l}\text { Roseau River at Oak Point } \\
\text { Roseau River below South Ditch No. 51, } \\
\text { Caribou }\end{array}$ & $\begin{array}{l}1933-39,1941-61 \\
1917,1920\end{array}$ \\
\hline 05112500 & $\begin{array}{l}\text { Roseau River at international boundary near } \\
\text { Caribou }\end{array}$ & $1933-65$ \\
\hline
\end{tabular}




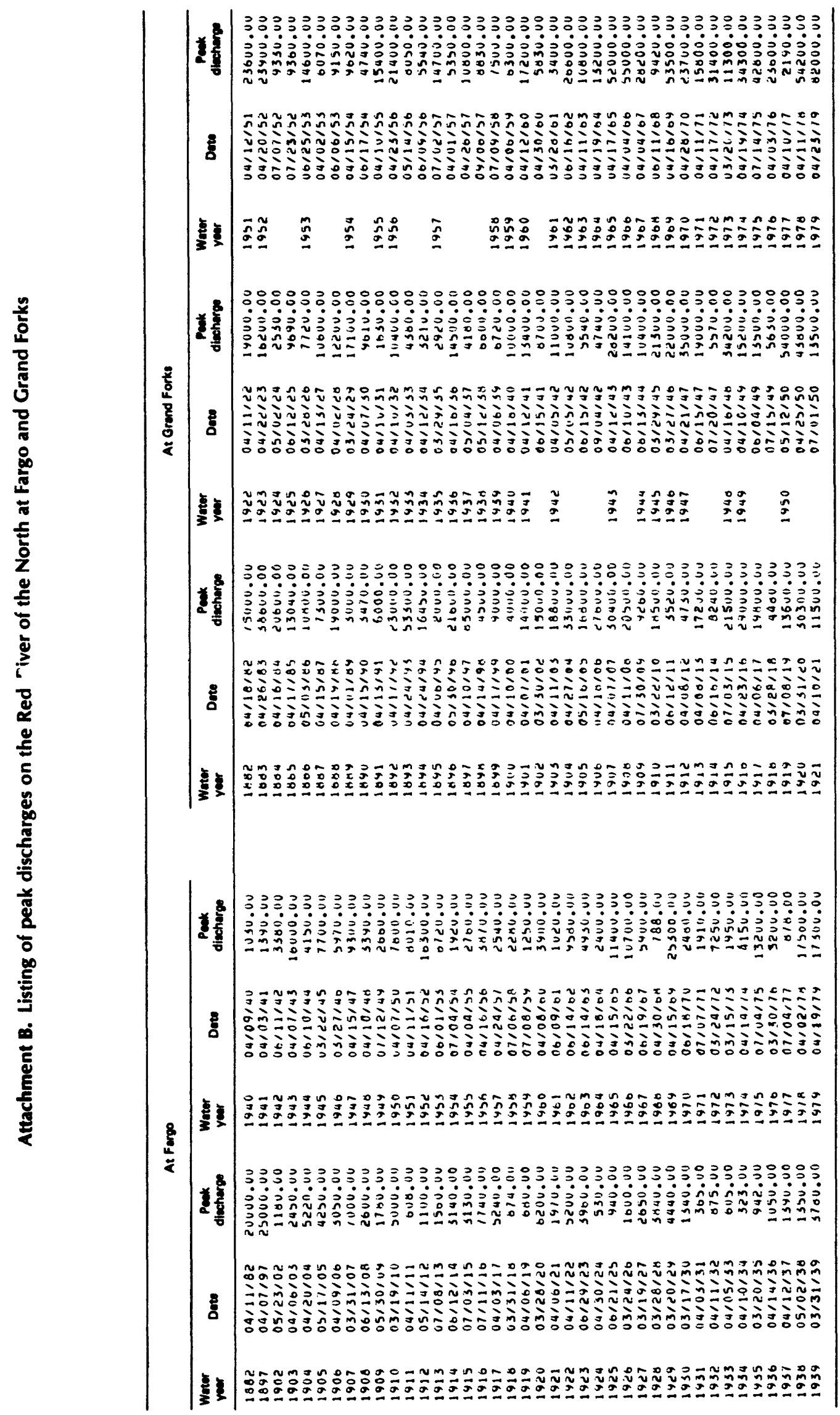

54 Flood Response, Red River, N. Dak. Dak-Minn. 
Attachment C1. Hydrographs for the Red River of the North at Fargo for the snowmelt-runoff period-March, April, and May
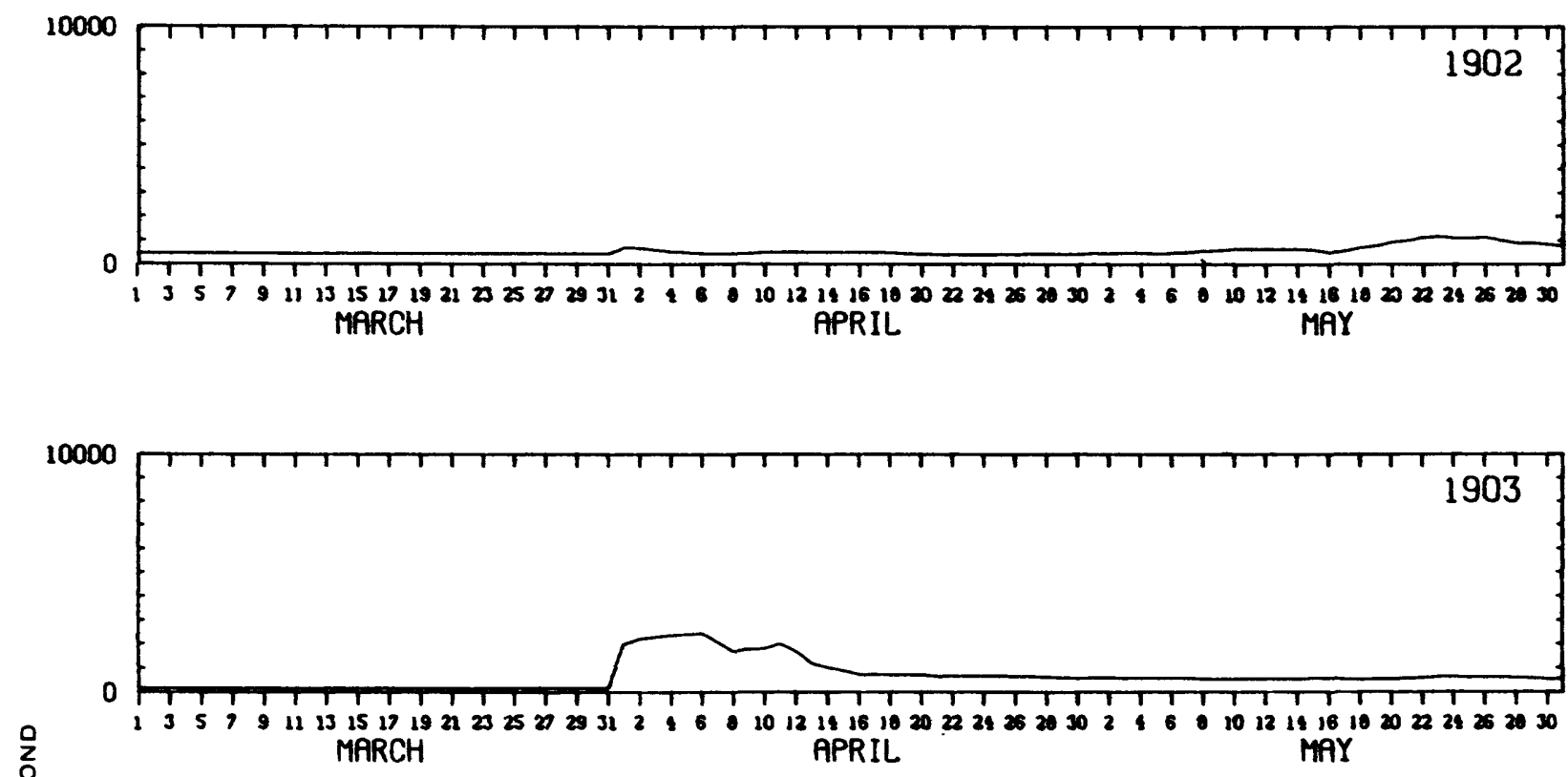

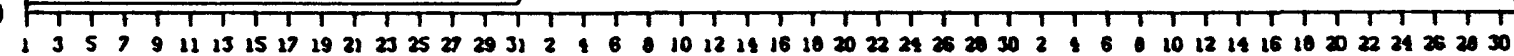
MARCH APRIL MAY
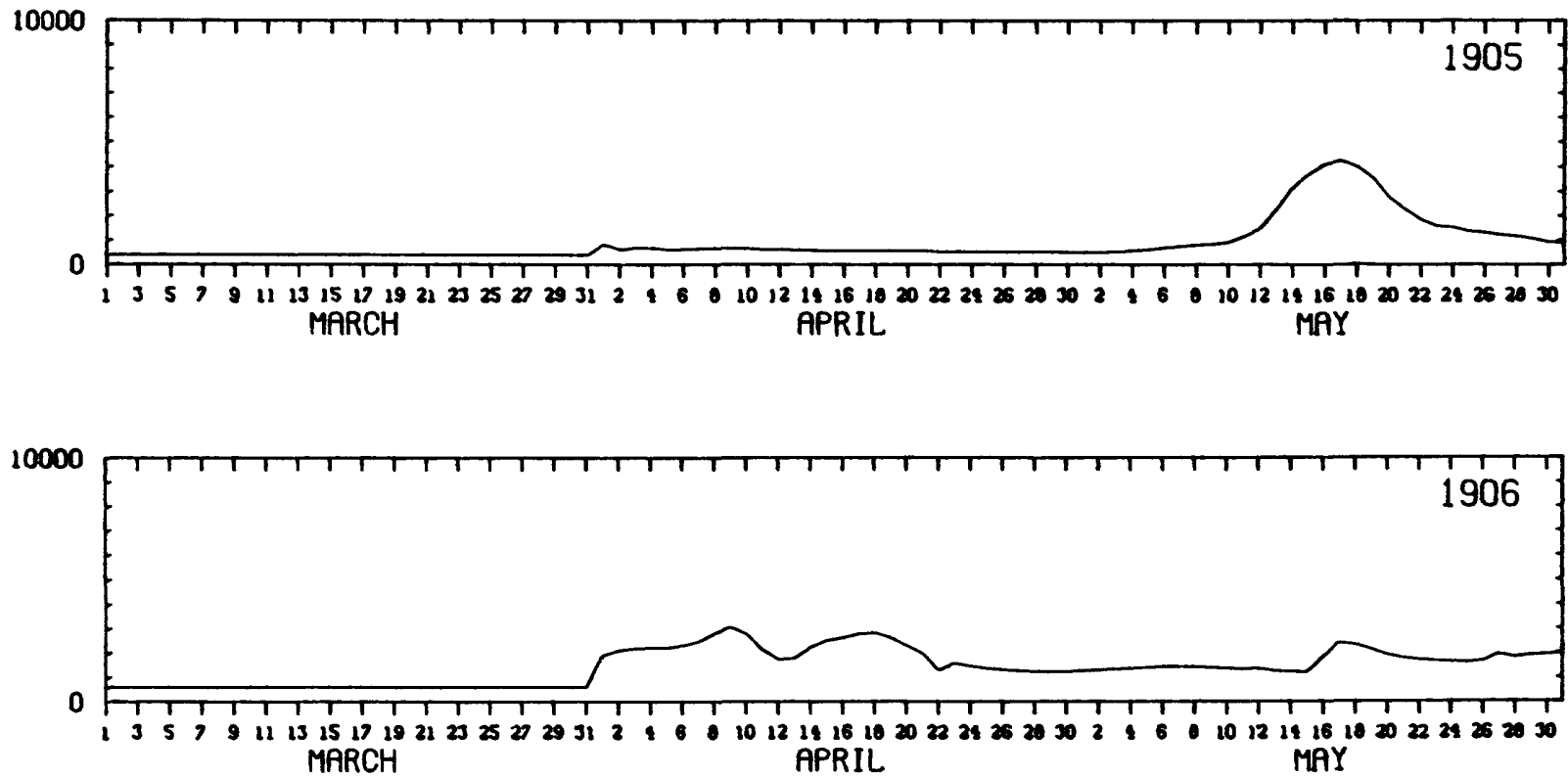
Aftachment C1. Continued
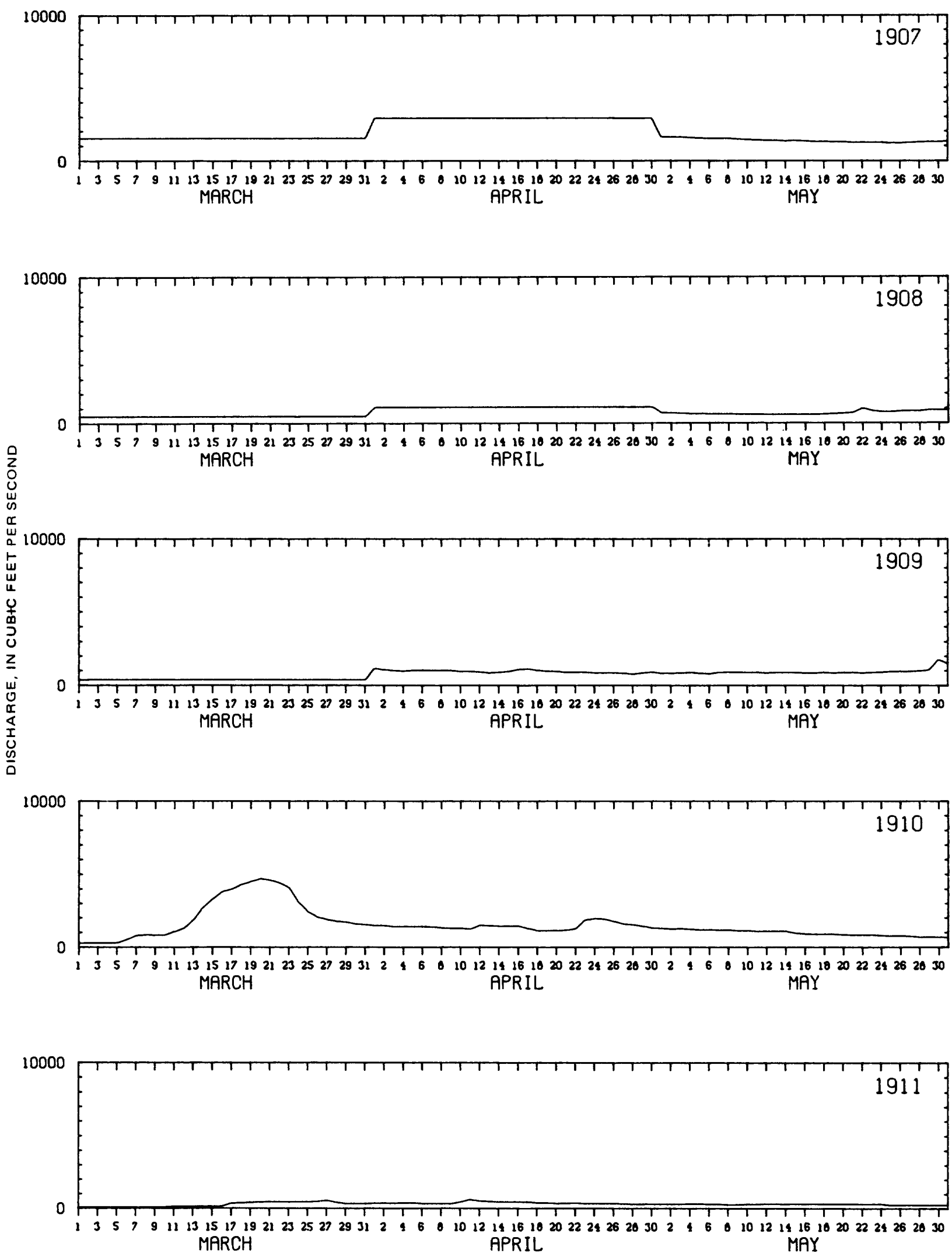
Attachment C1. Continued
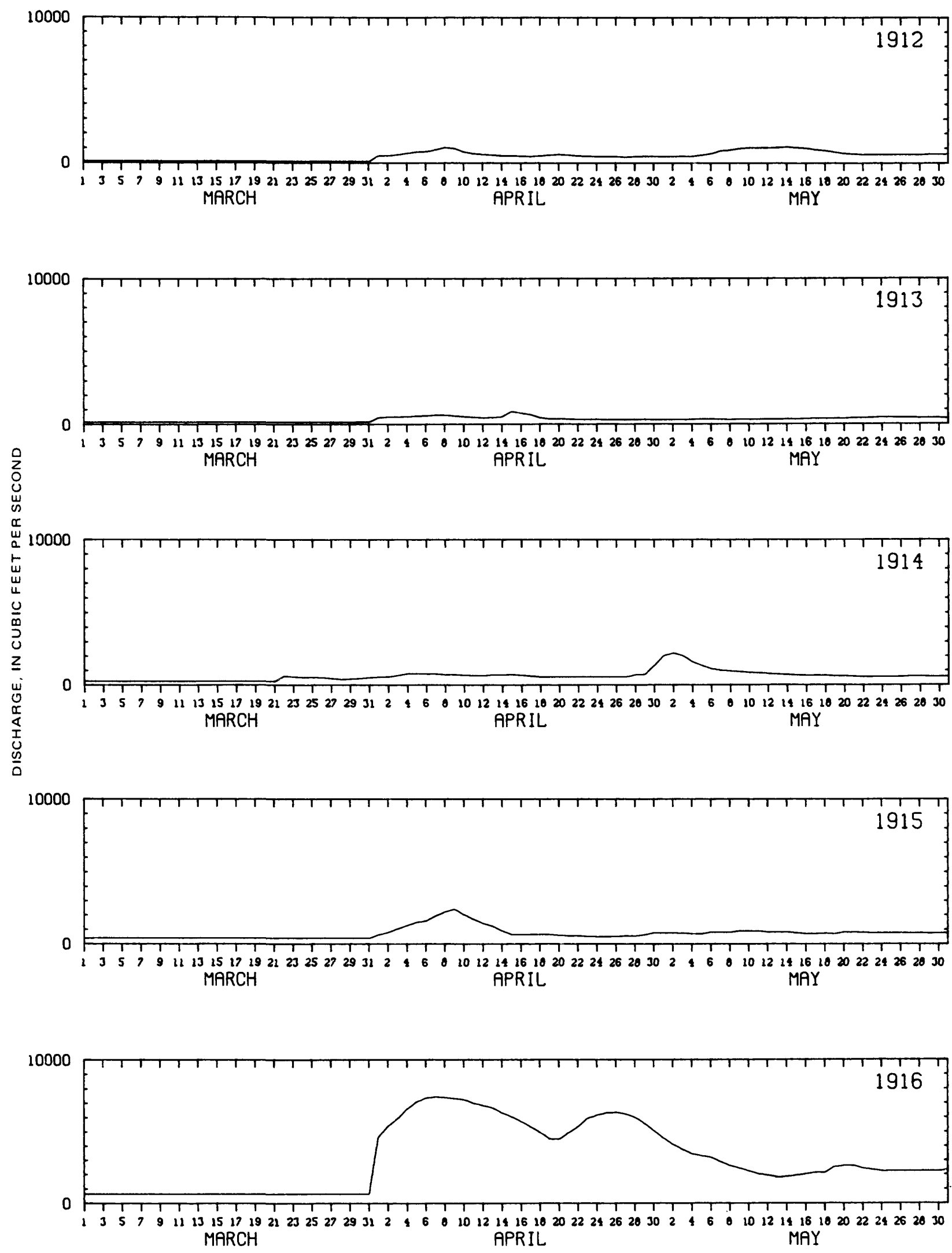

Attachment C 57 
Attachment C1. Continued
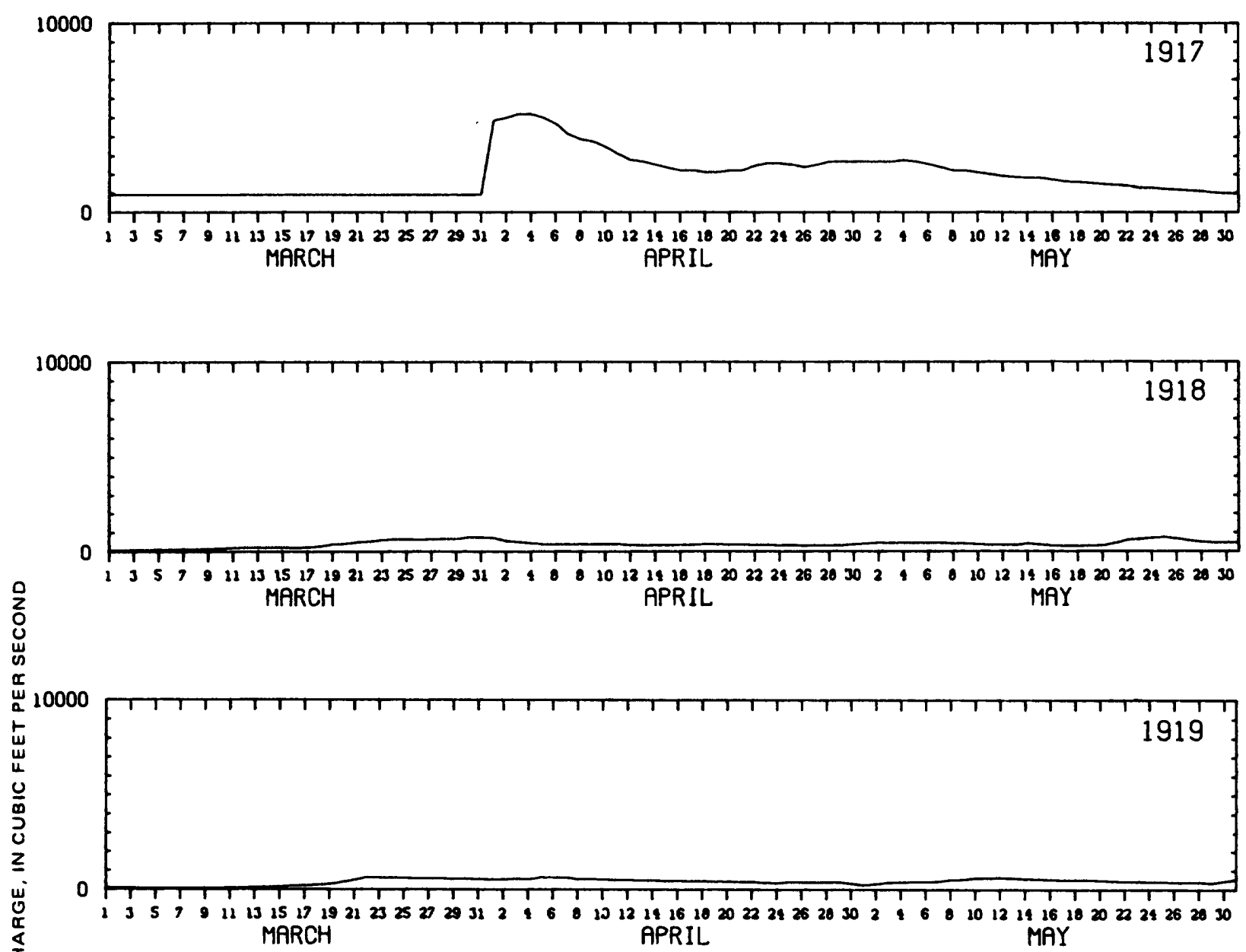

10000

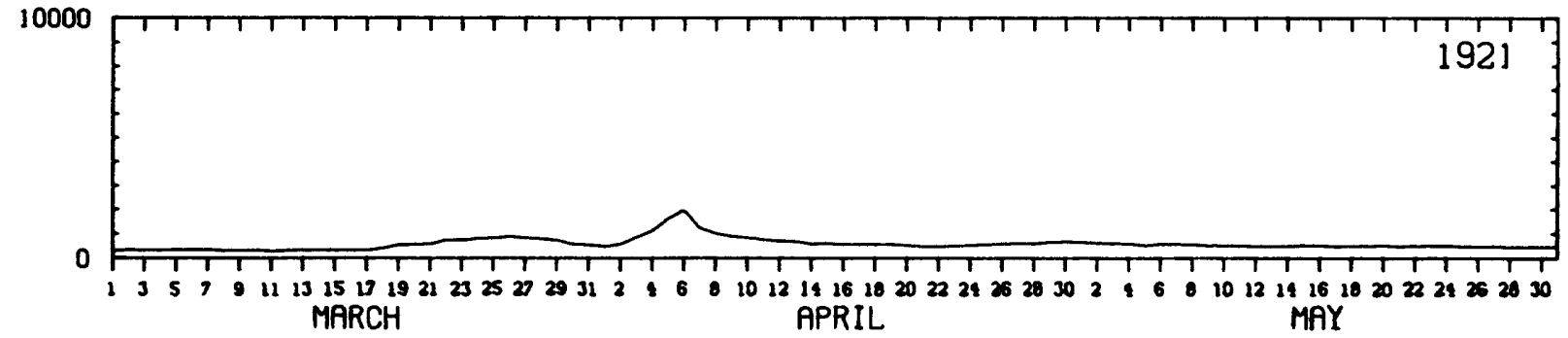


Attachment C1. Continued
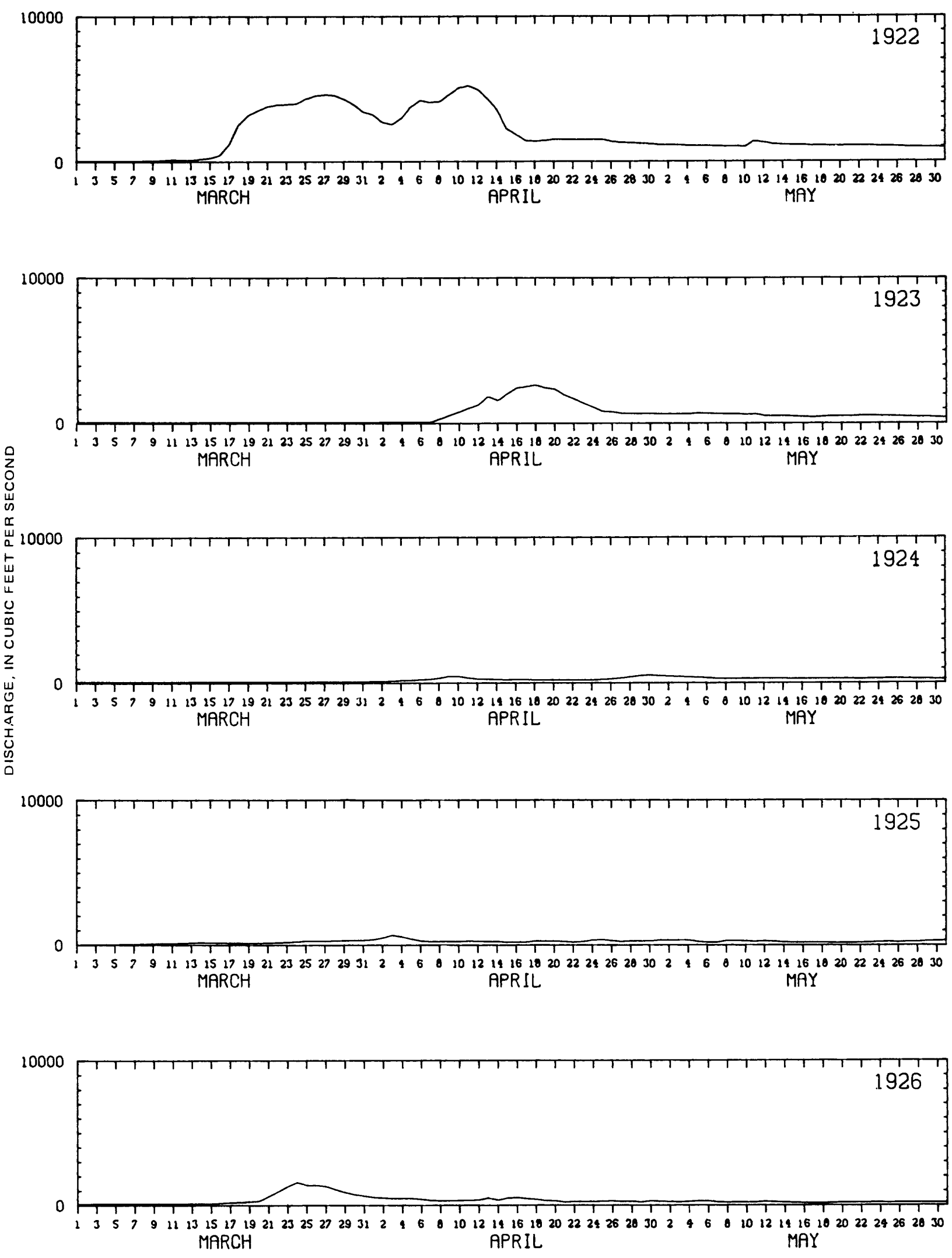

Attachment C 59 
Attachment C1. Continued
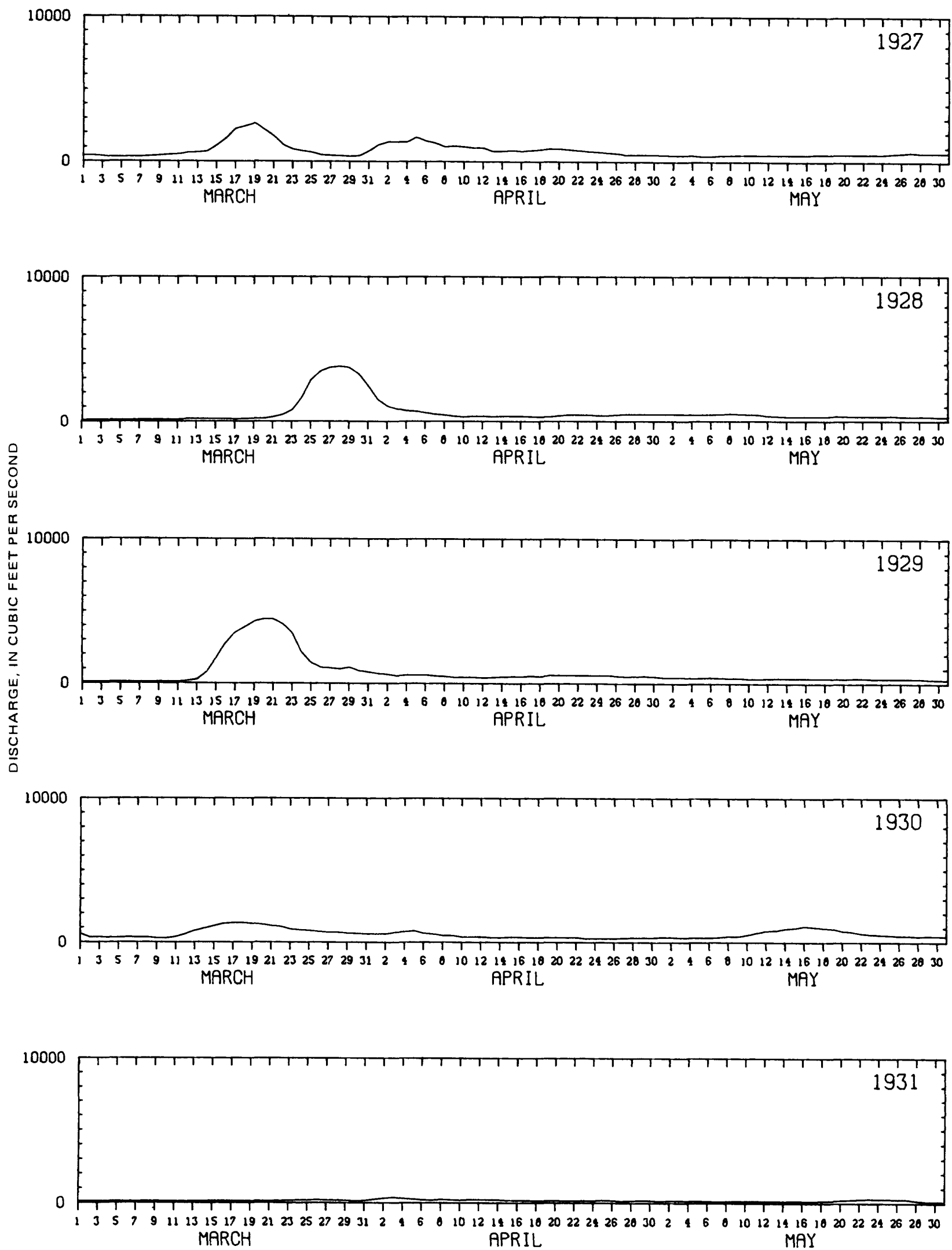

60 Flood Response, Red River, N. Dak. Dak-Minn. 
Attachment C1. Continued
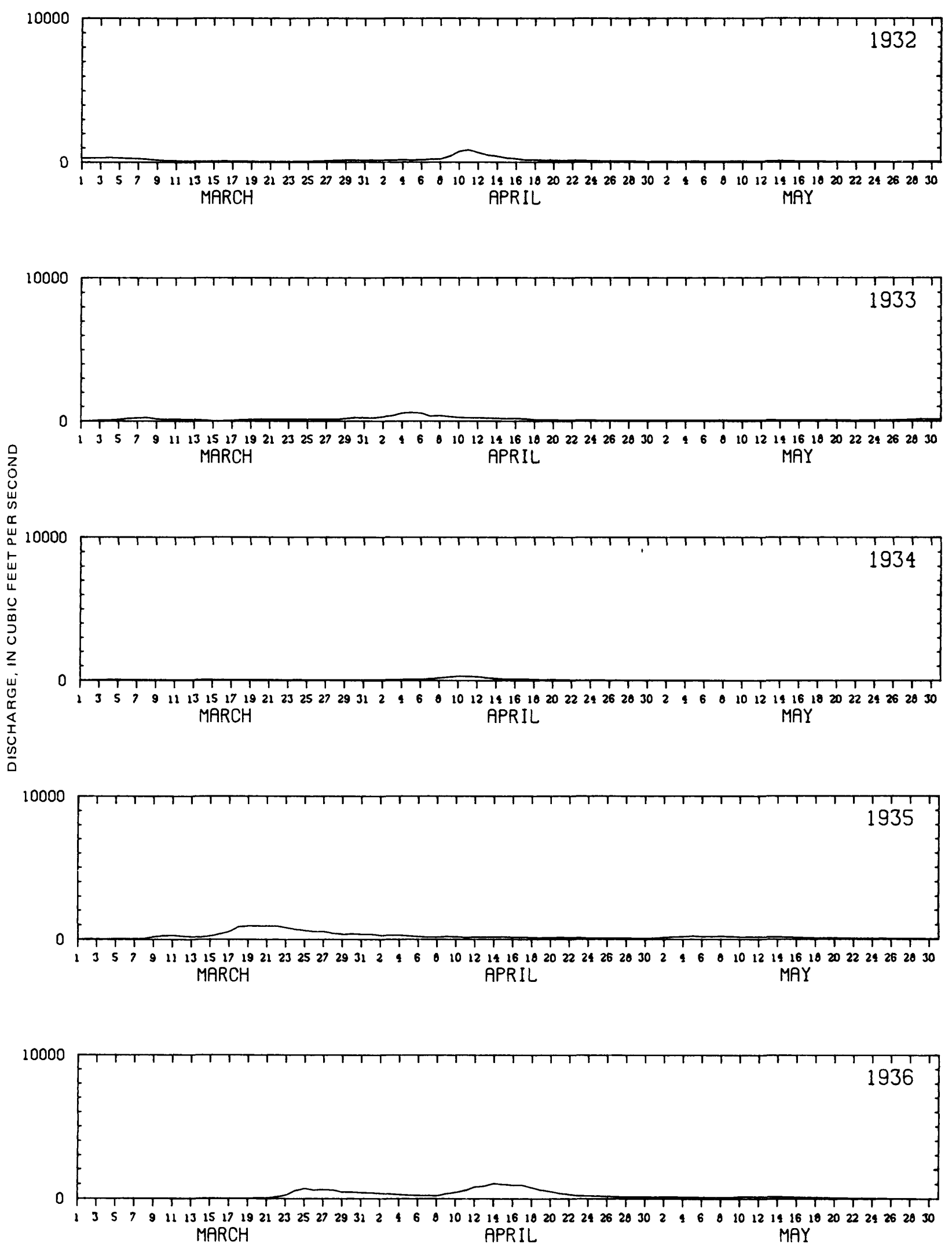

Attachment C 61 
Attachment C1. Continued
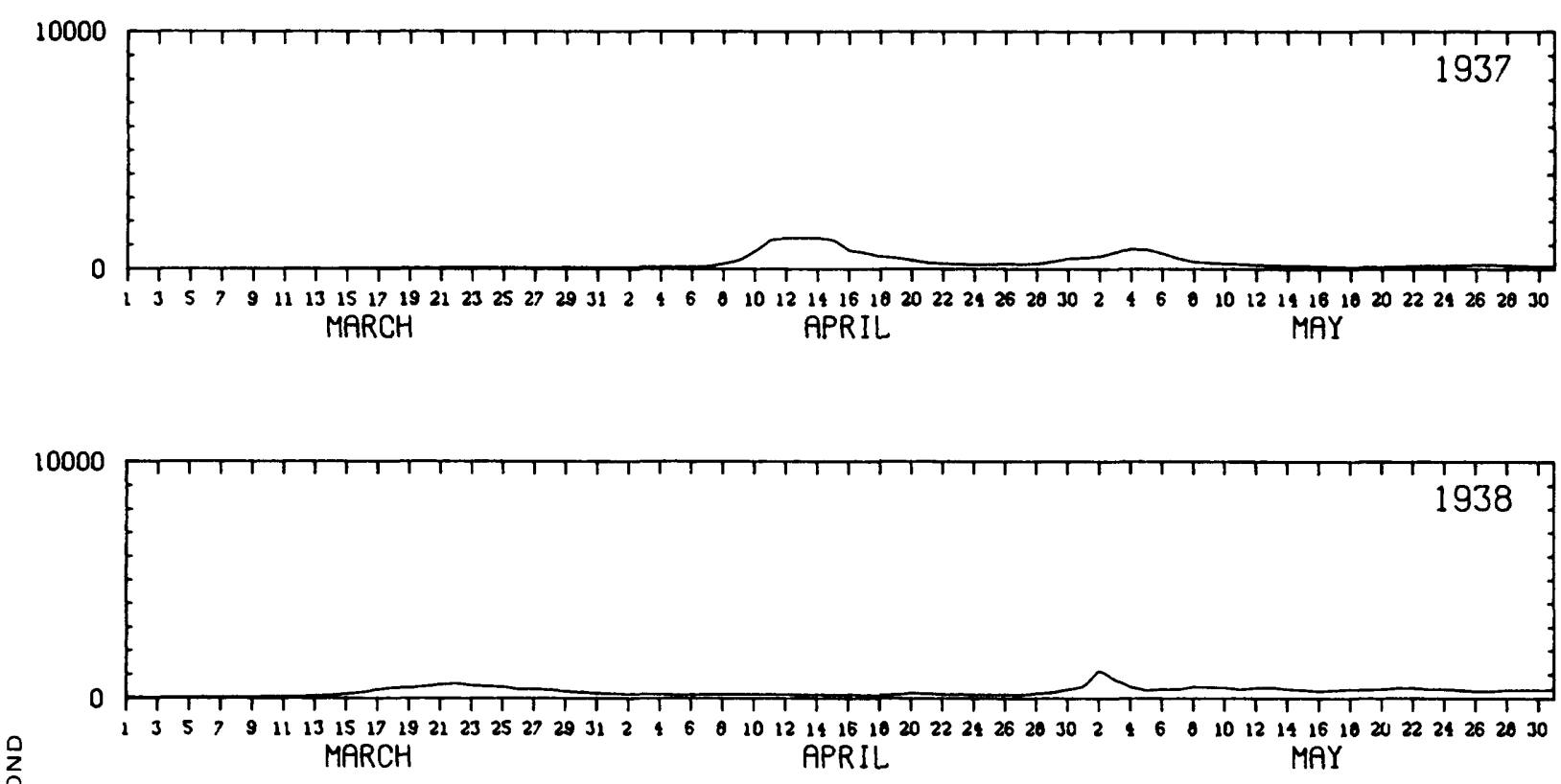

0

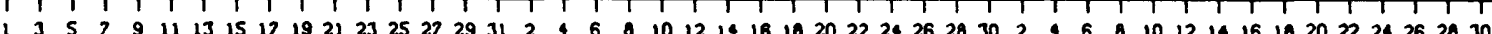
MARCH APRIL
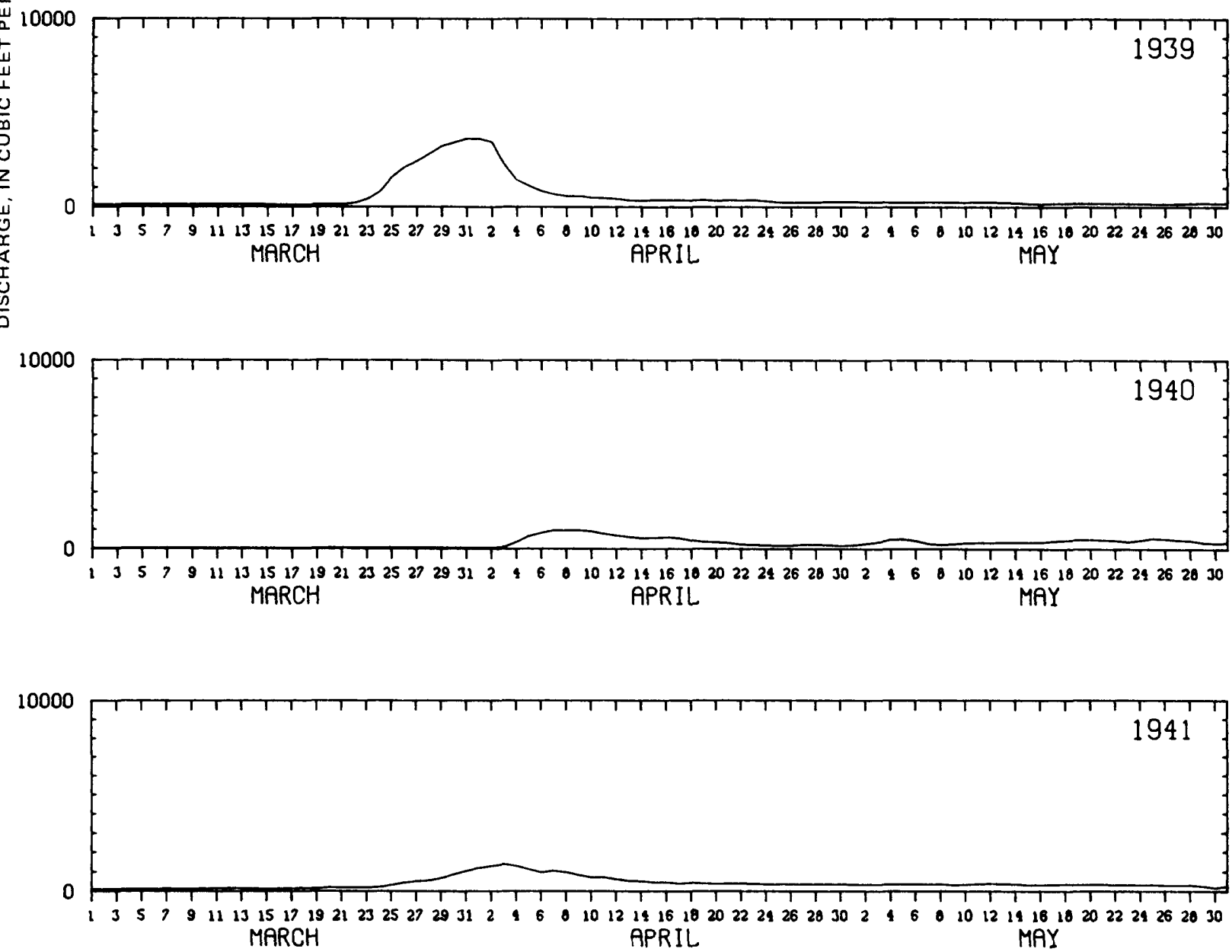
Attachment C1. Continued
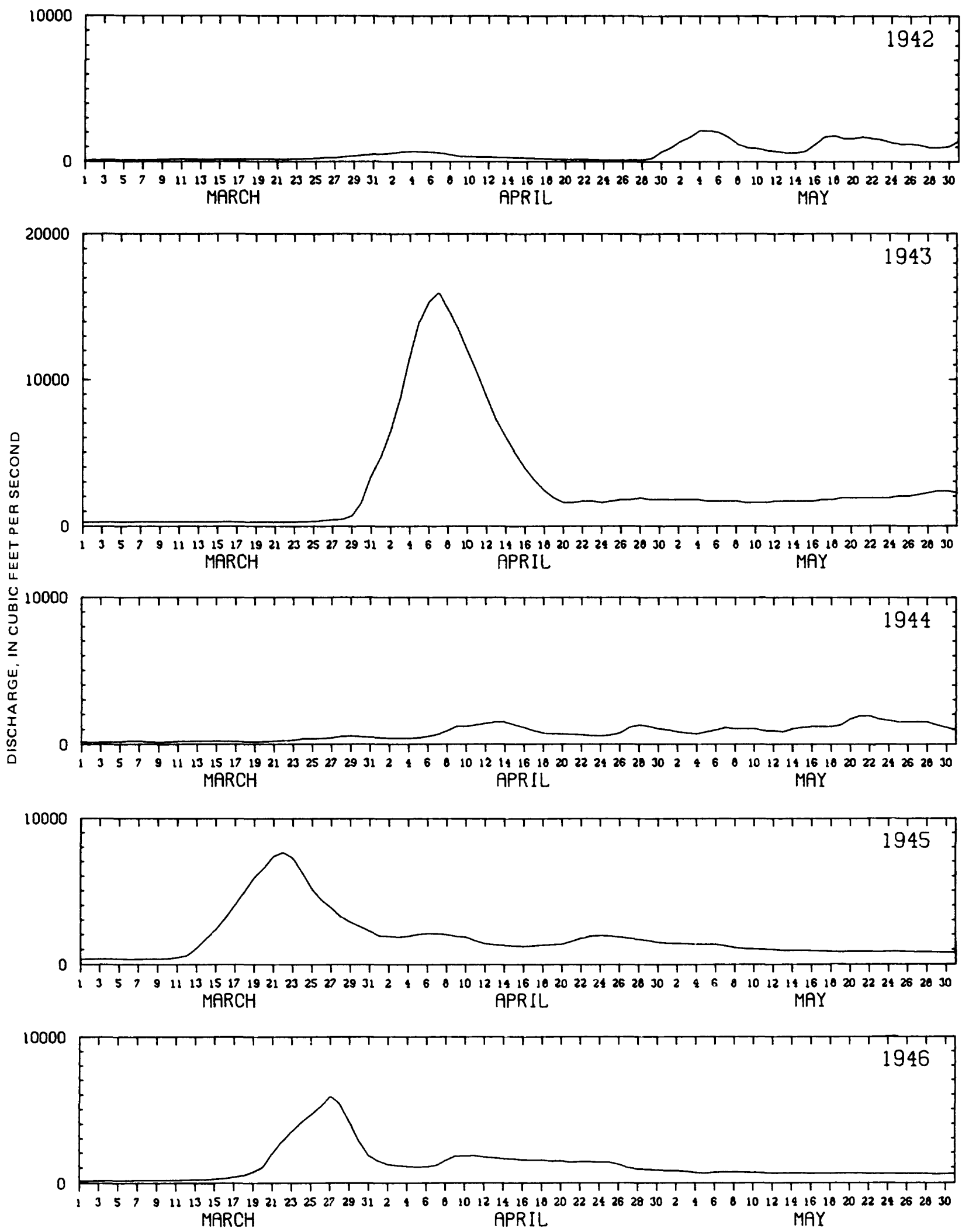
Attachment C1. Continued
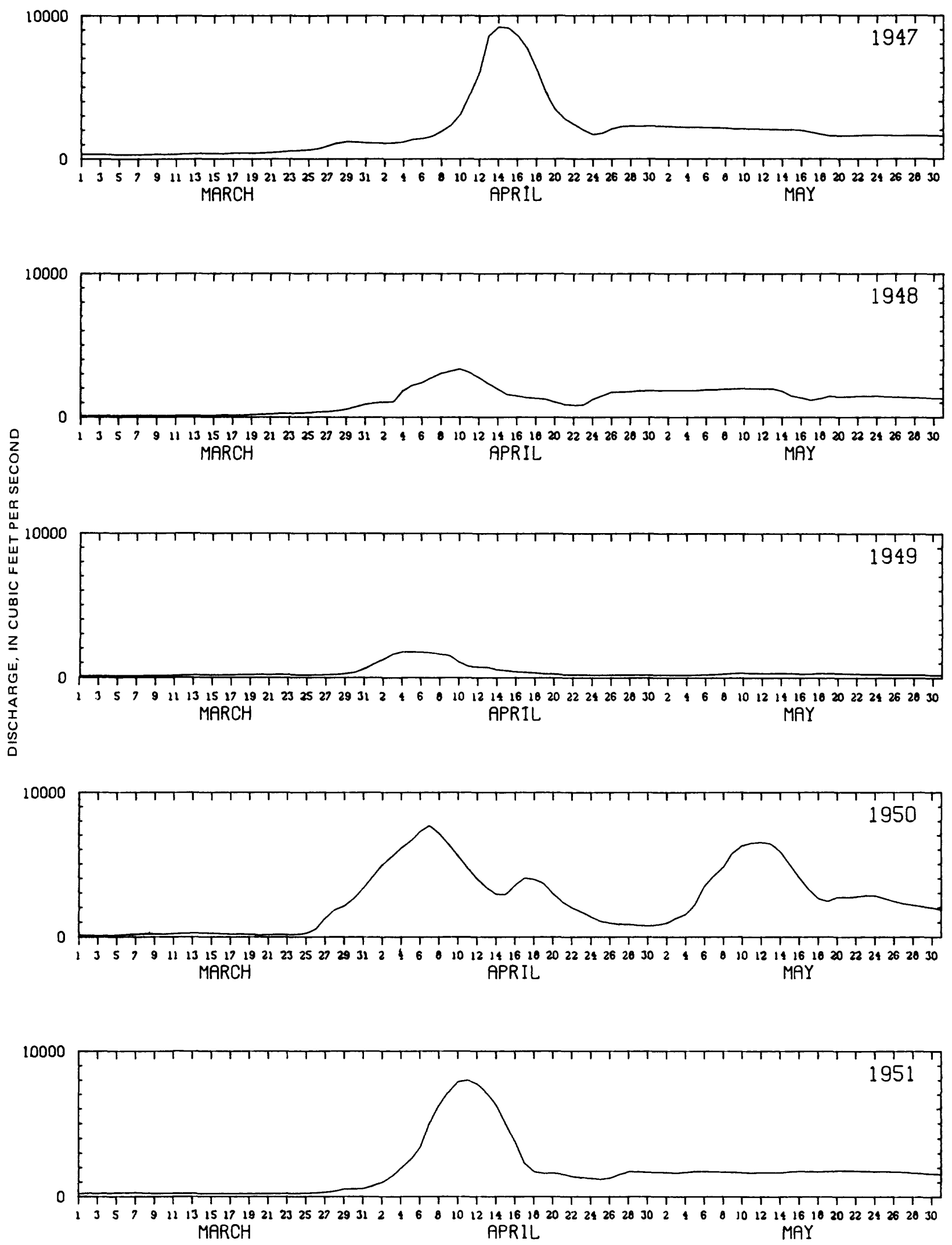
Attachment C1. Continued
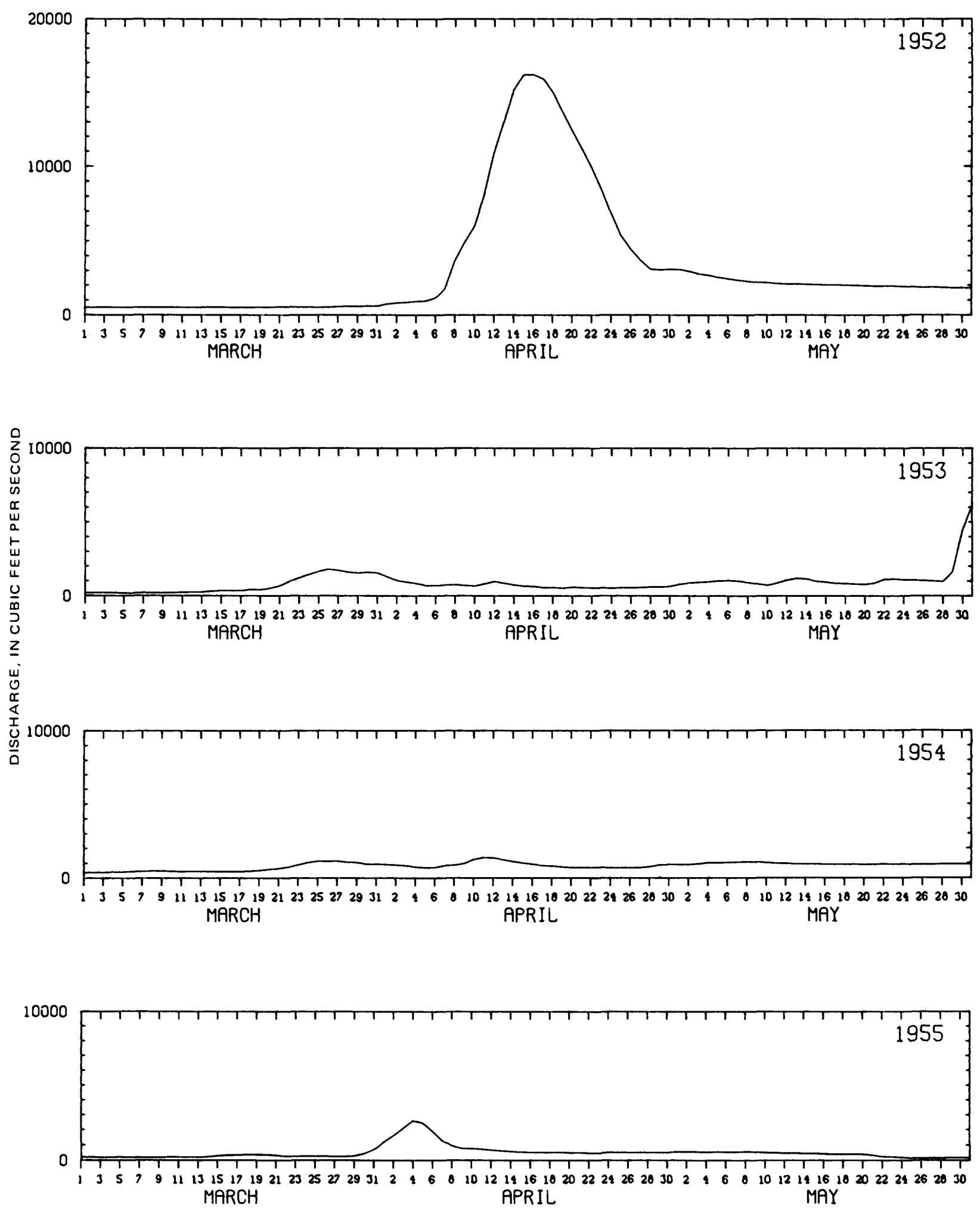

Attachment C 65 
Attachment C1. Continued
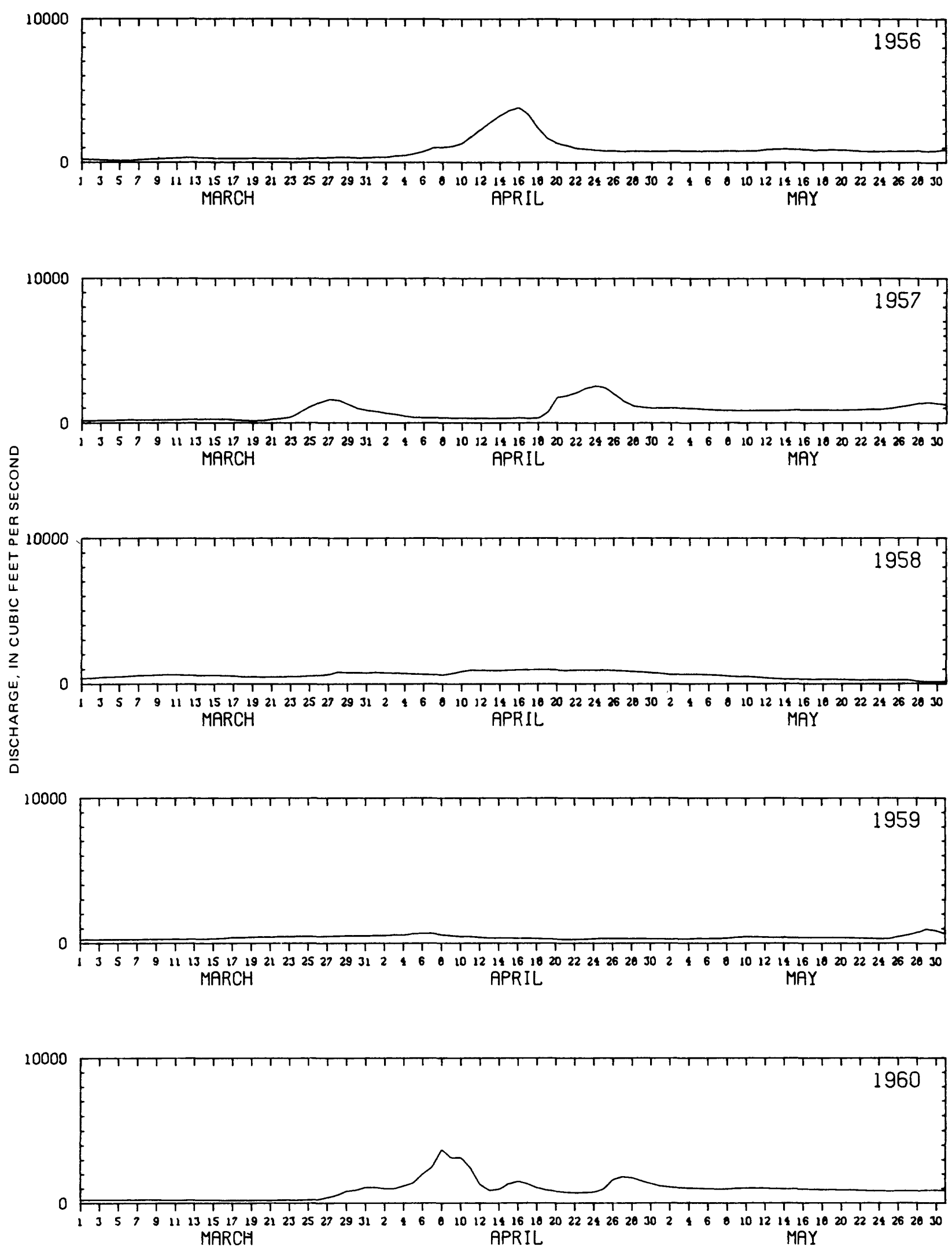

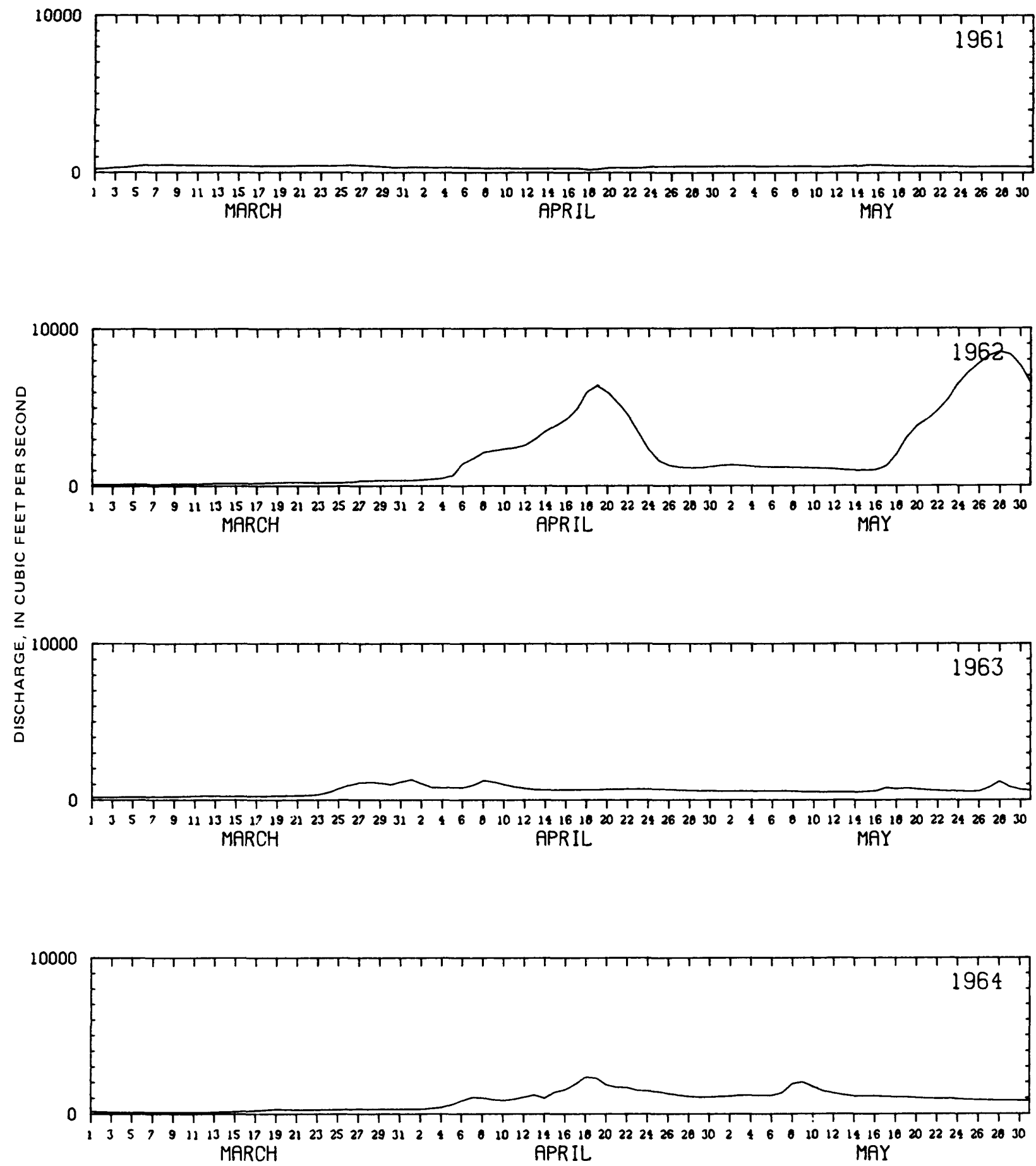
Attachment C1. Continued
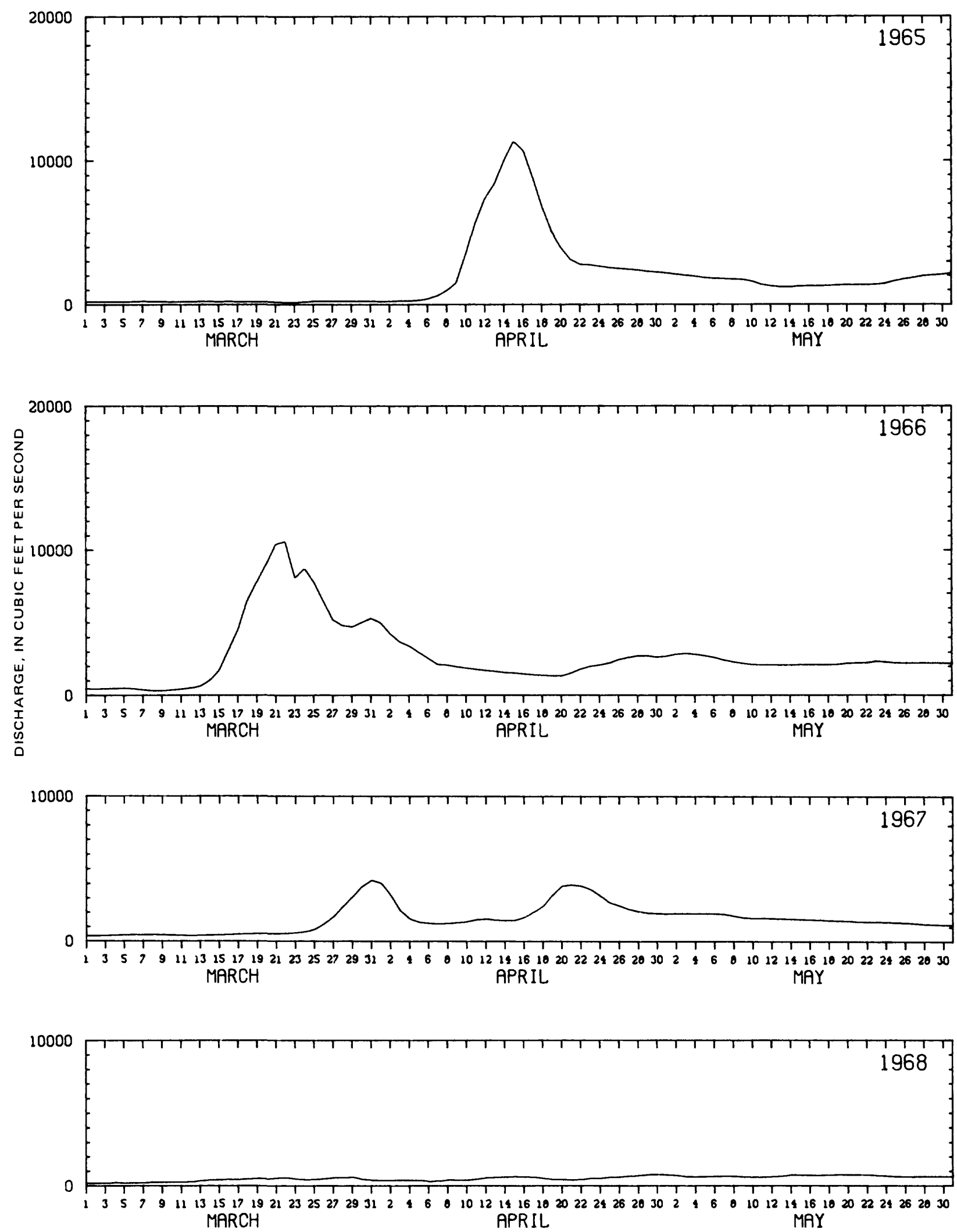
Attachment C1. Continued
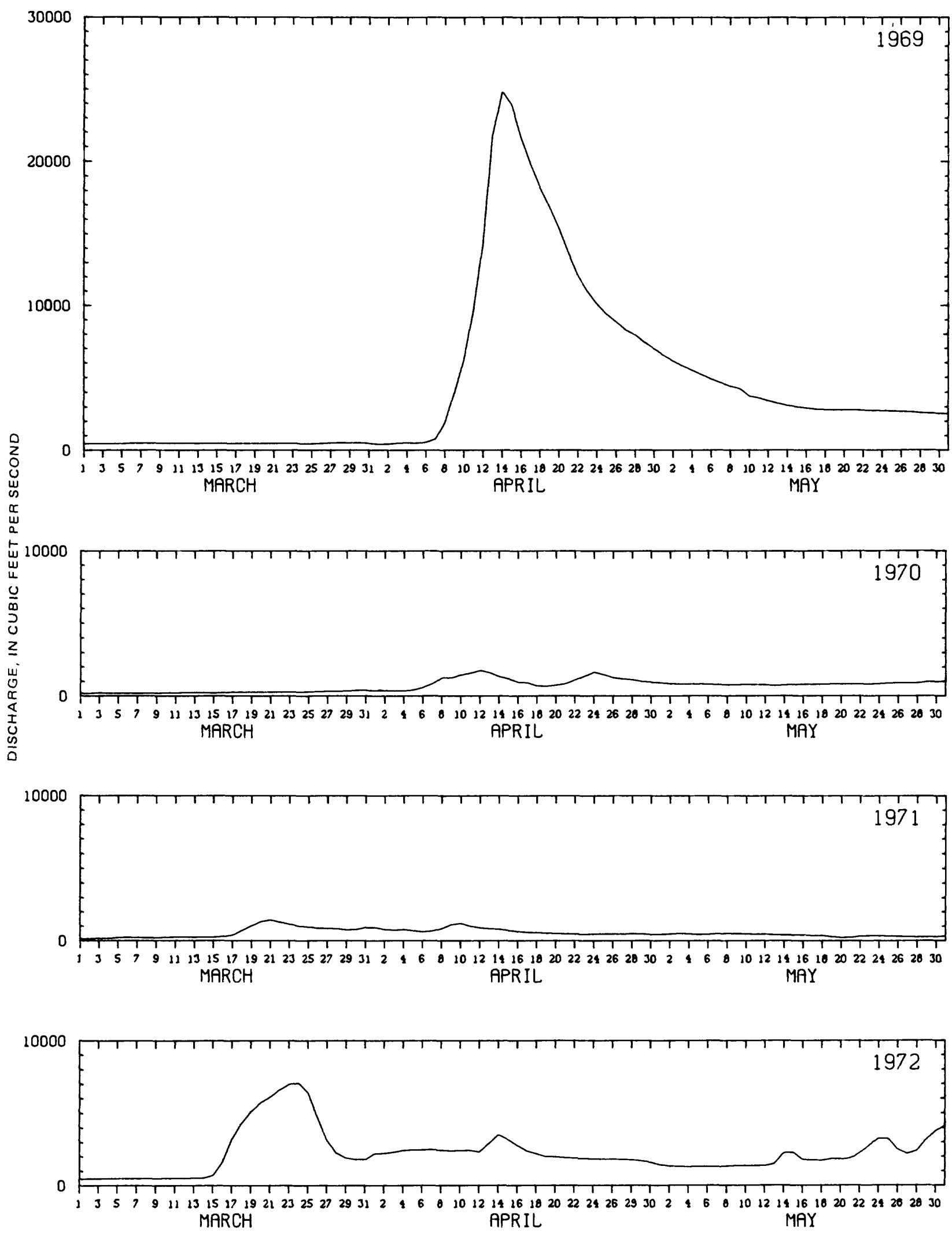

Attachment C 69 
Attachment C1. Continued
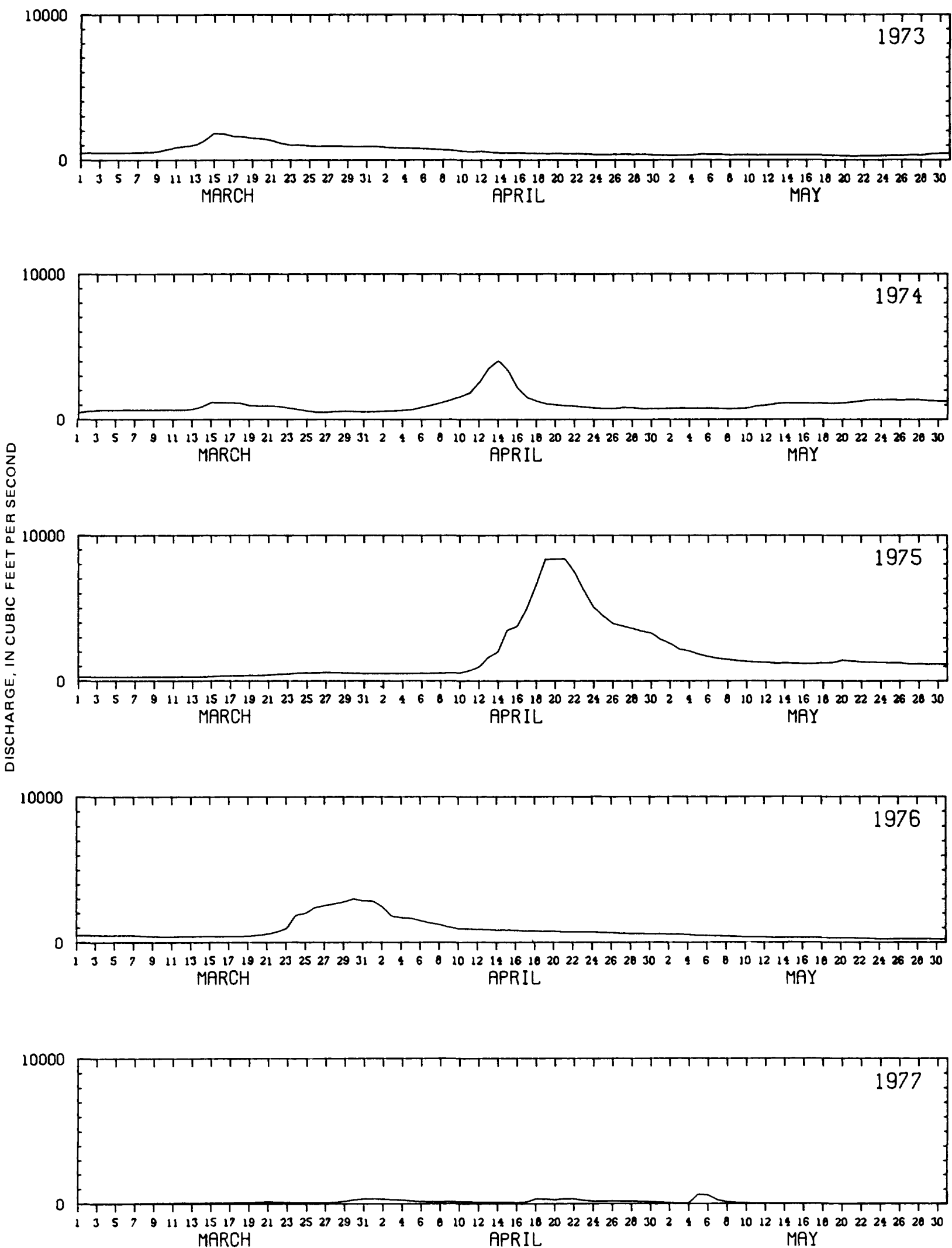


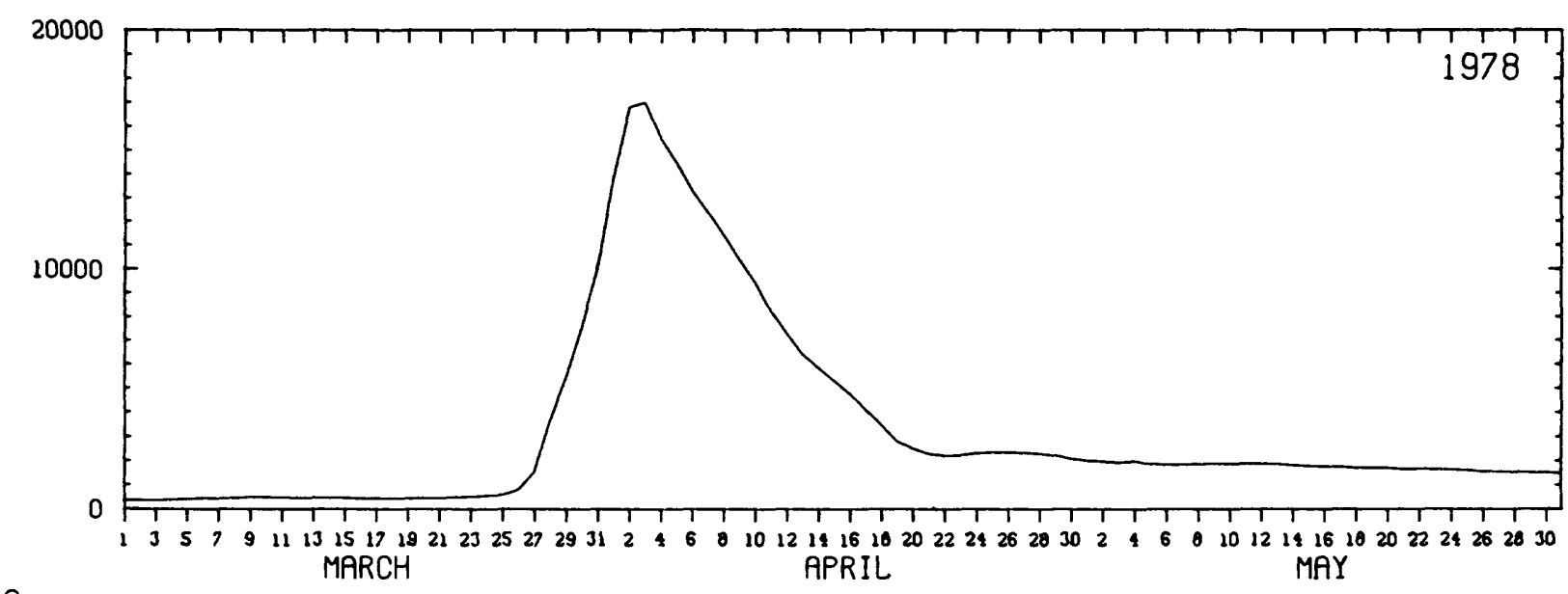

O MARCH 1416162022242620302246
APRIL
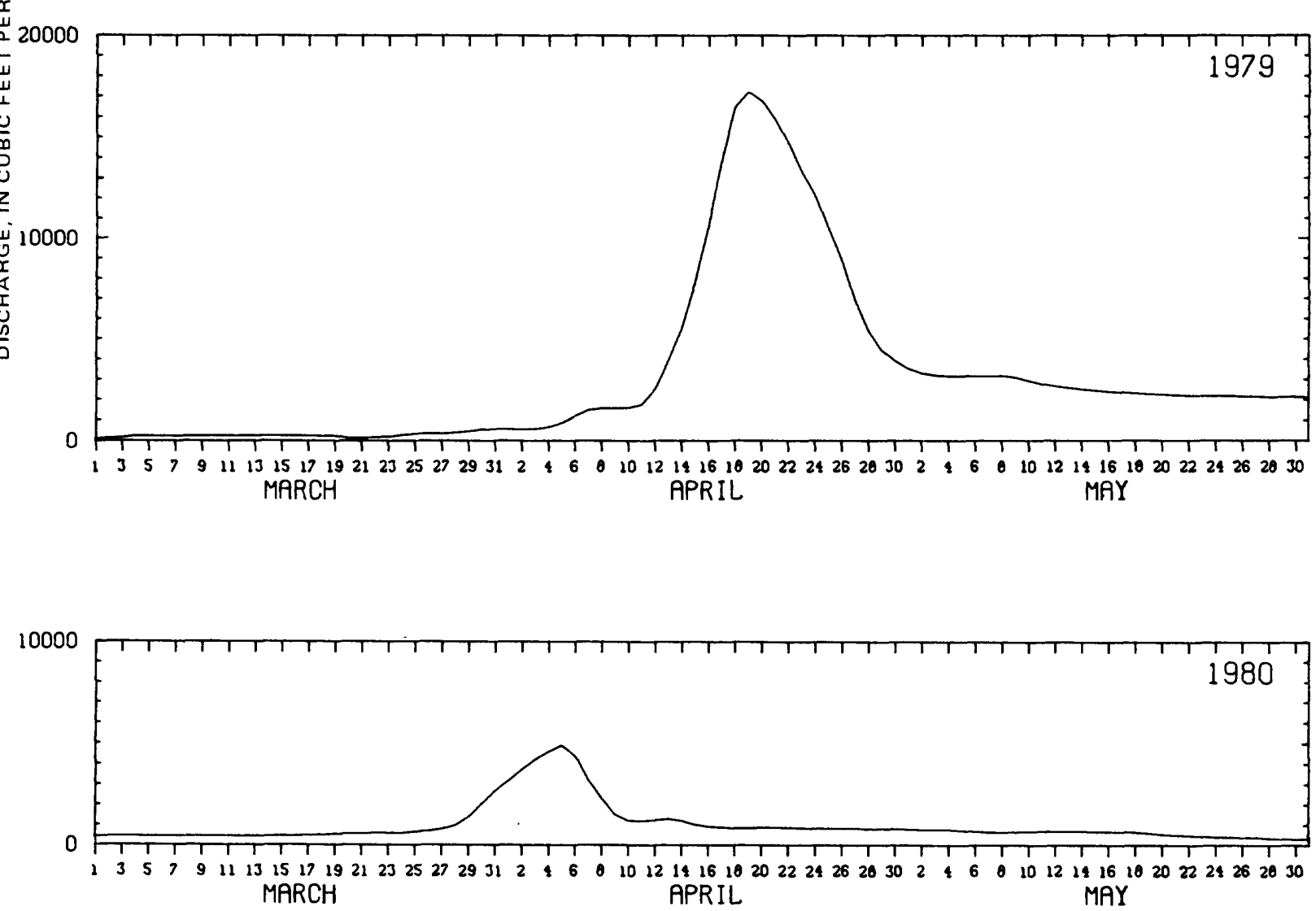

Attachment C 71 
Attachment C2. Hydrographs for the Red River of the North at Grand Forks for the snowmelt-runoff periodMarch, April, and May
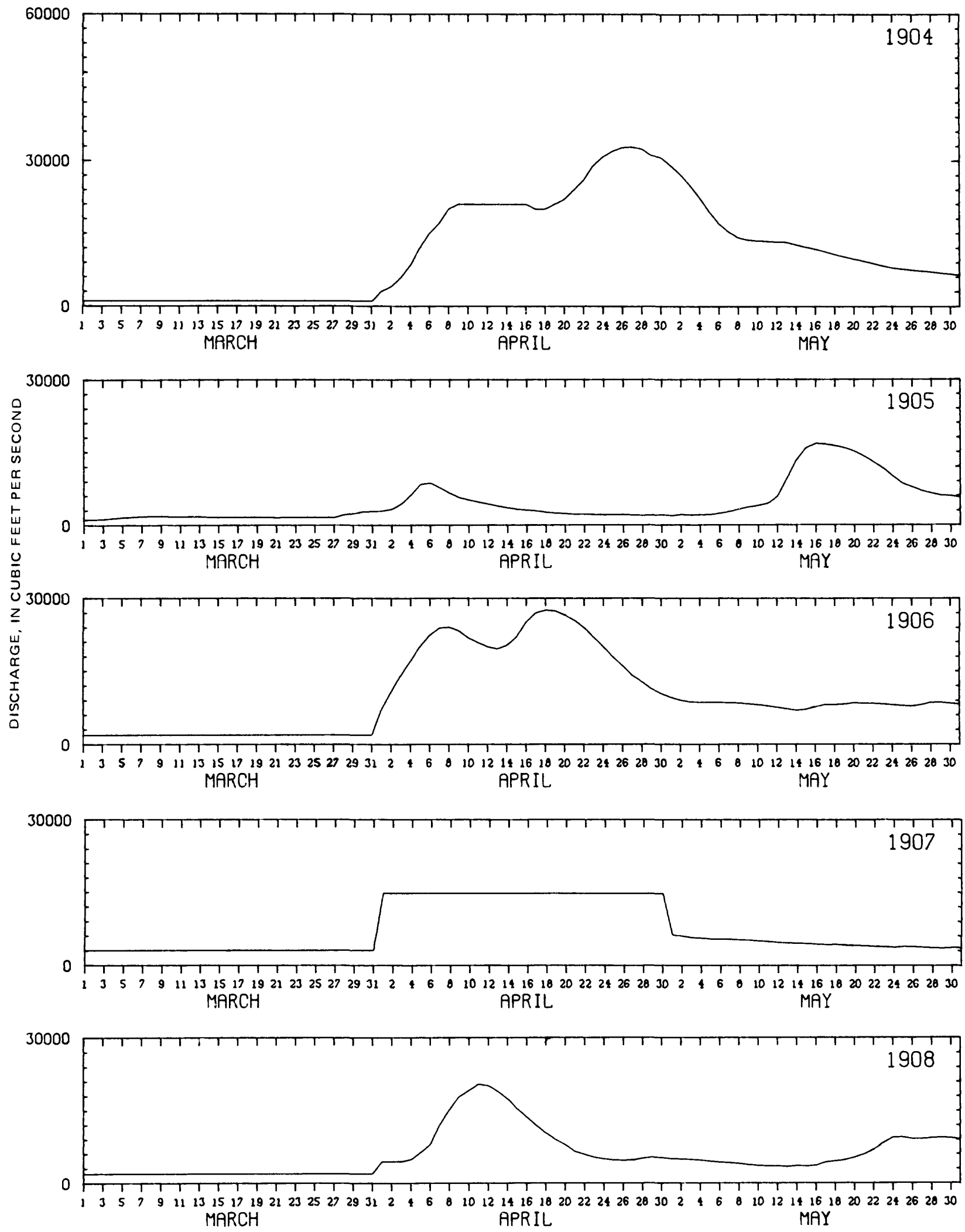
Attachment C2. Continued
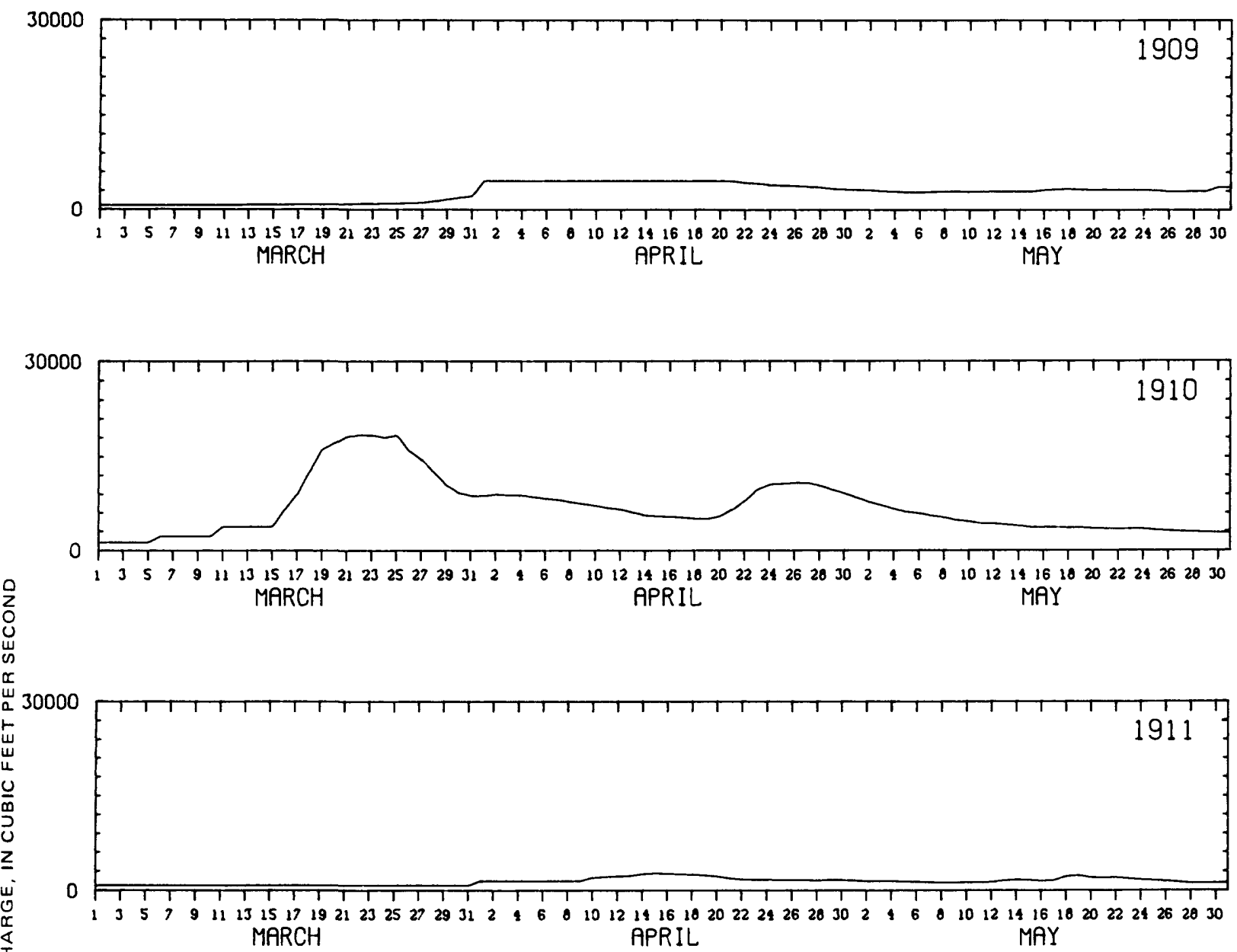

0
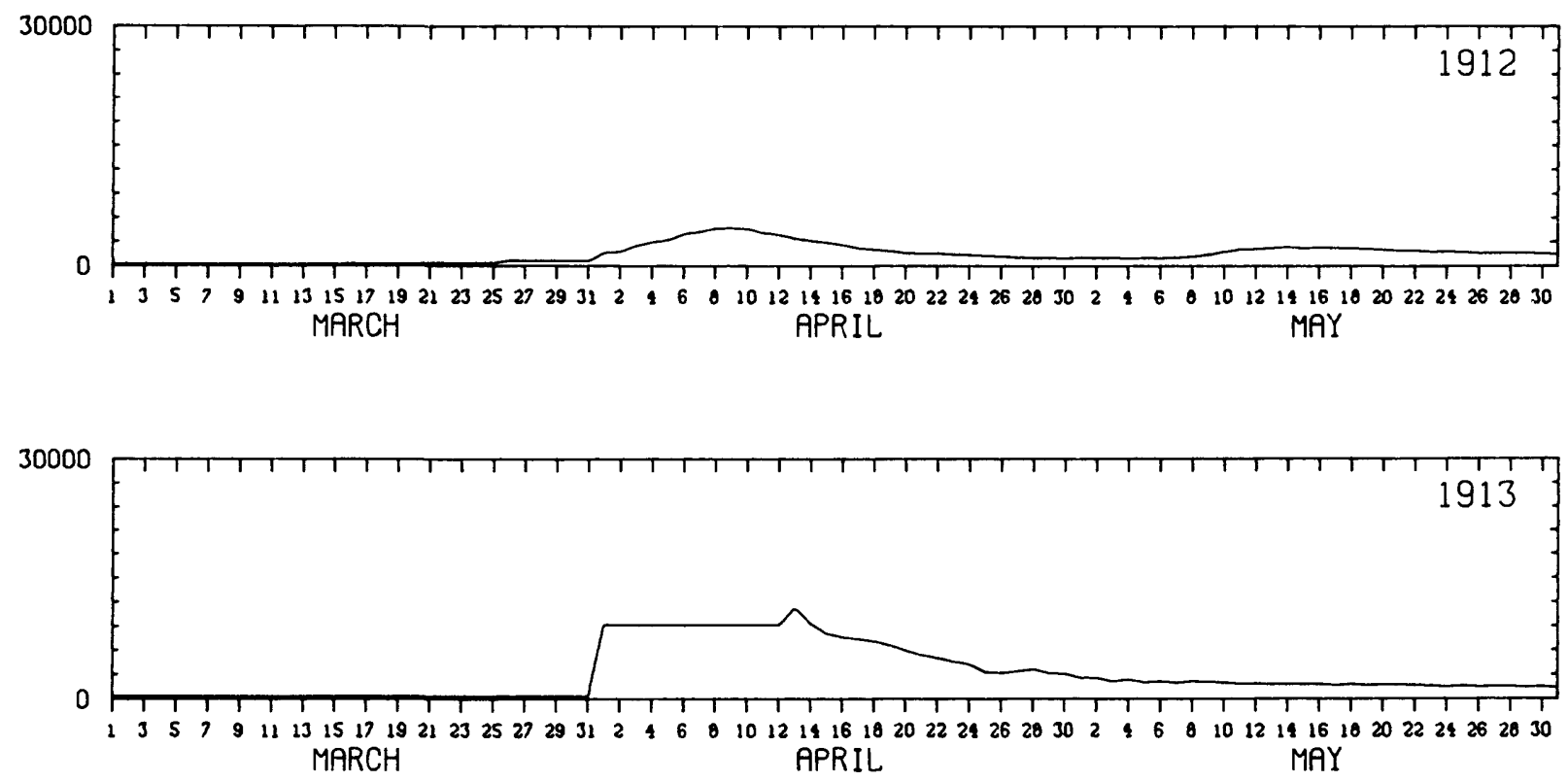

Attachment C 73 
Attachment C2. Continued
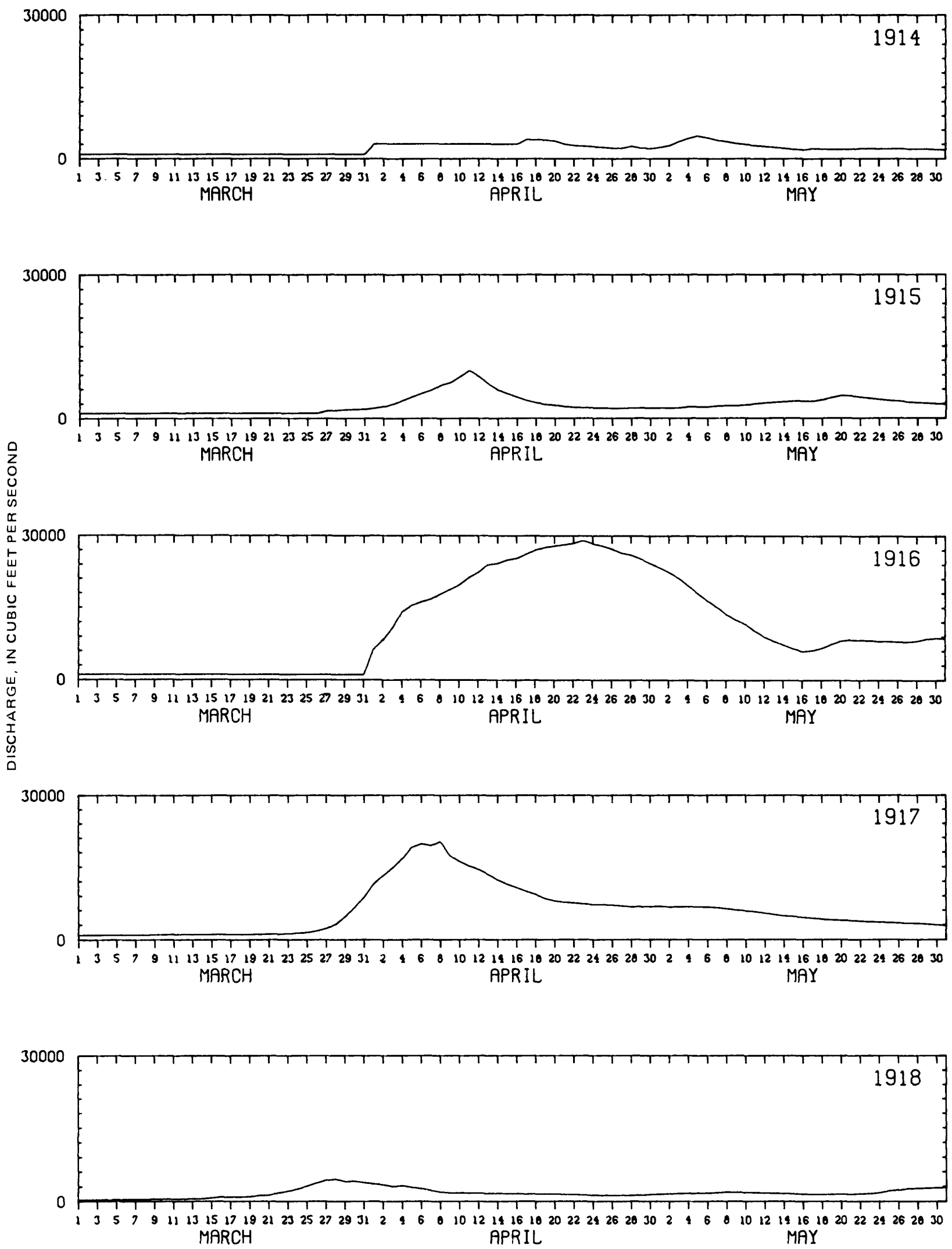
Attachment C2. Continued
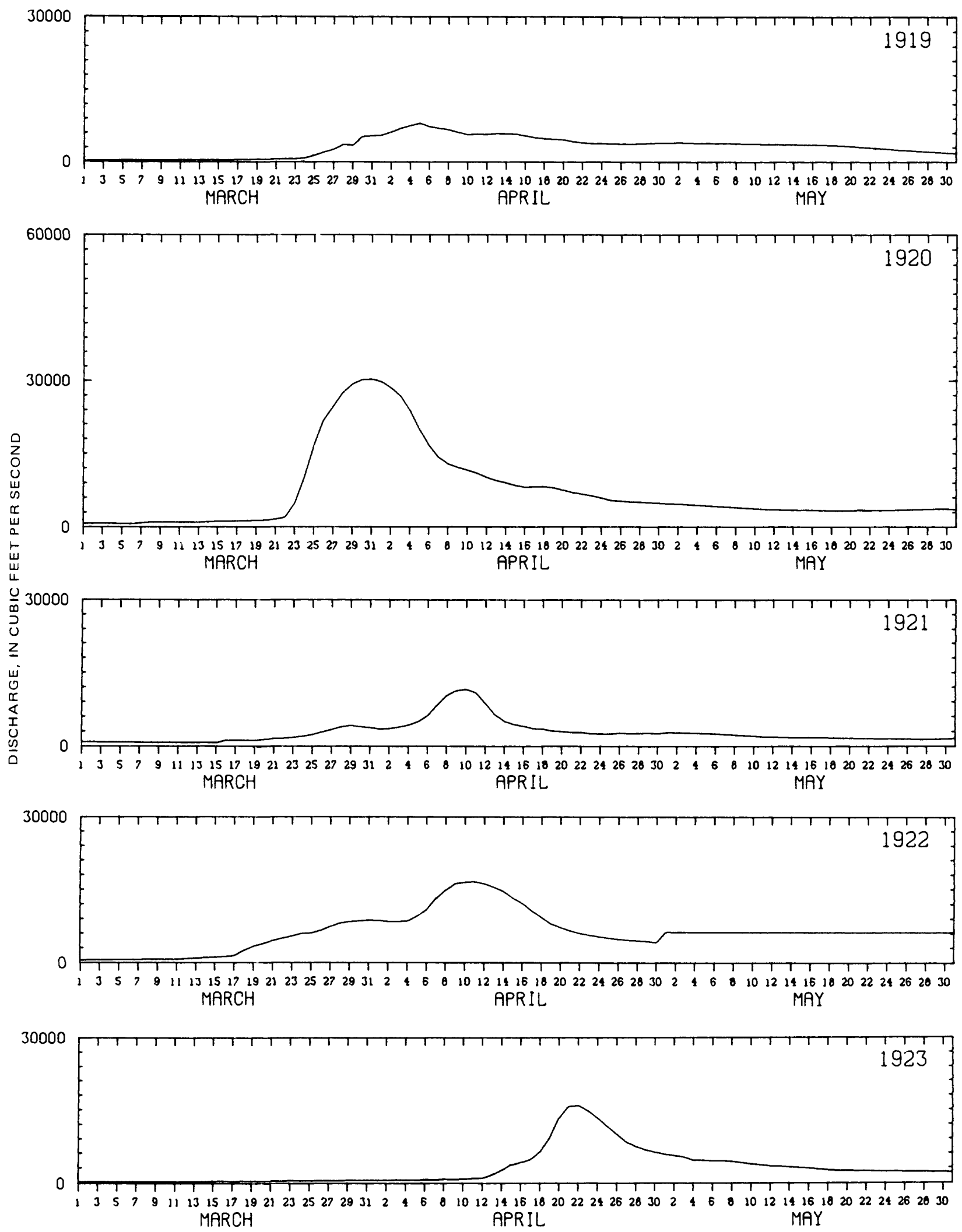
Attachment C2. Continued
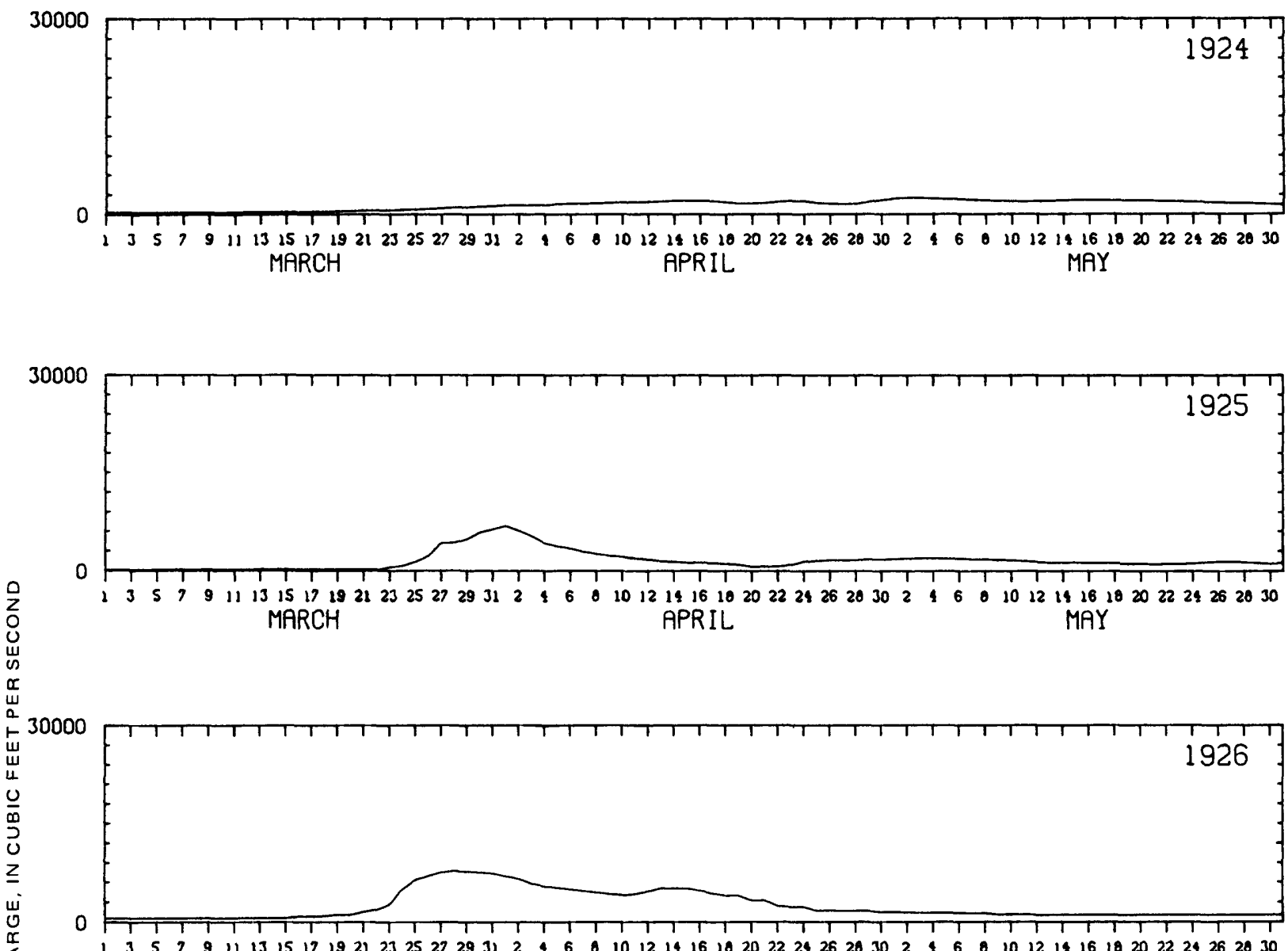

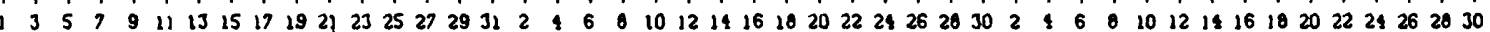
MARCH APRIL

MAY
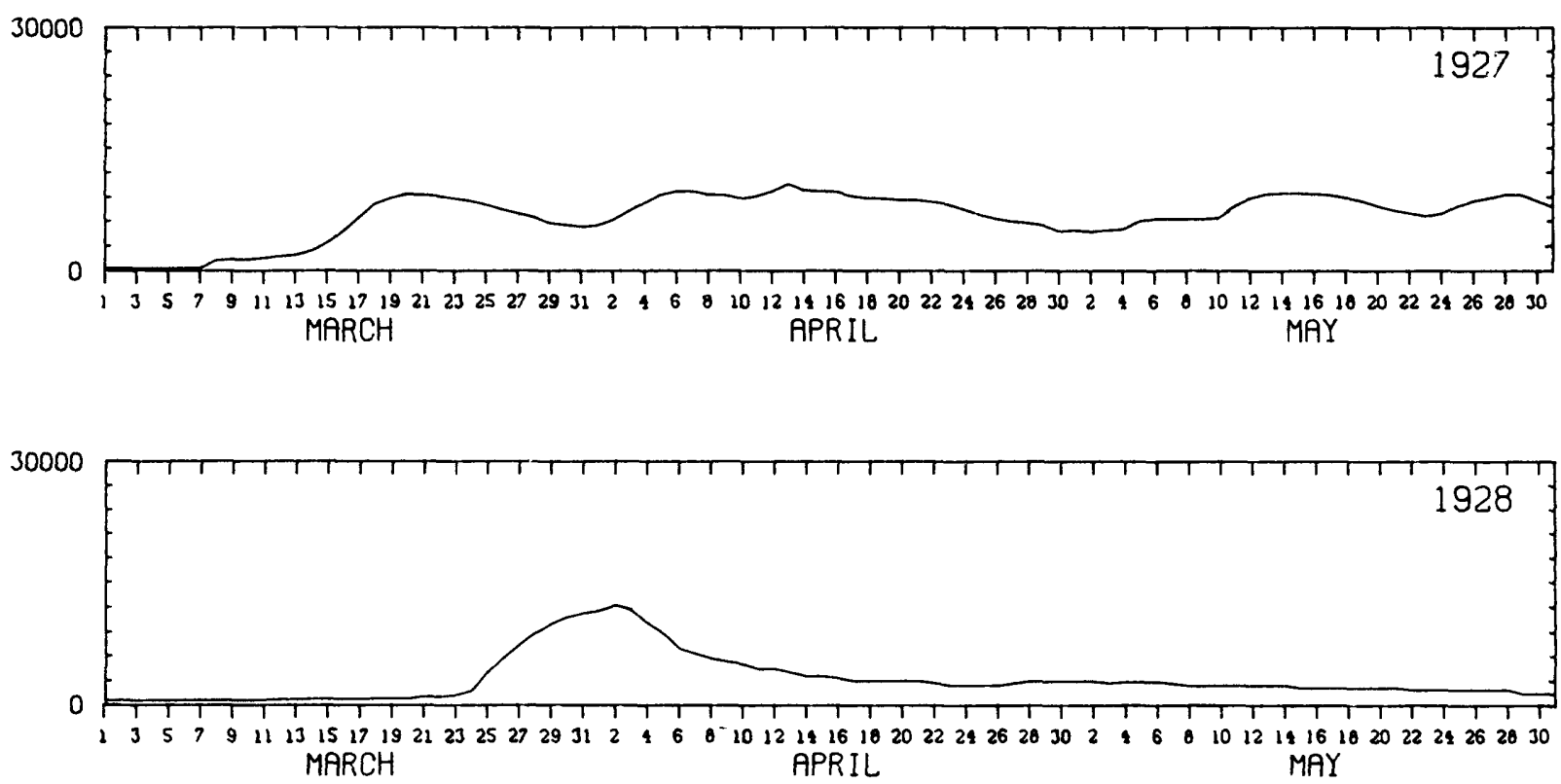
Attachment C2. Continued
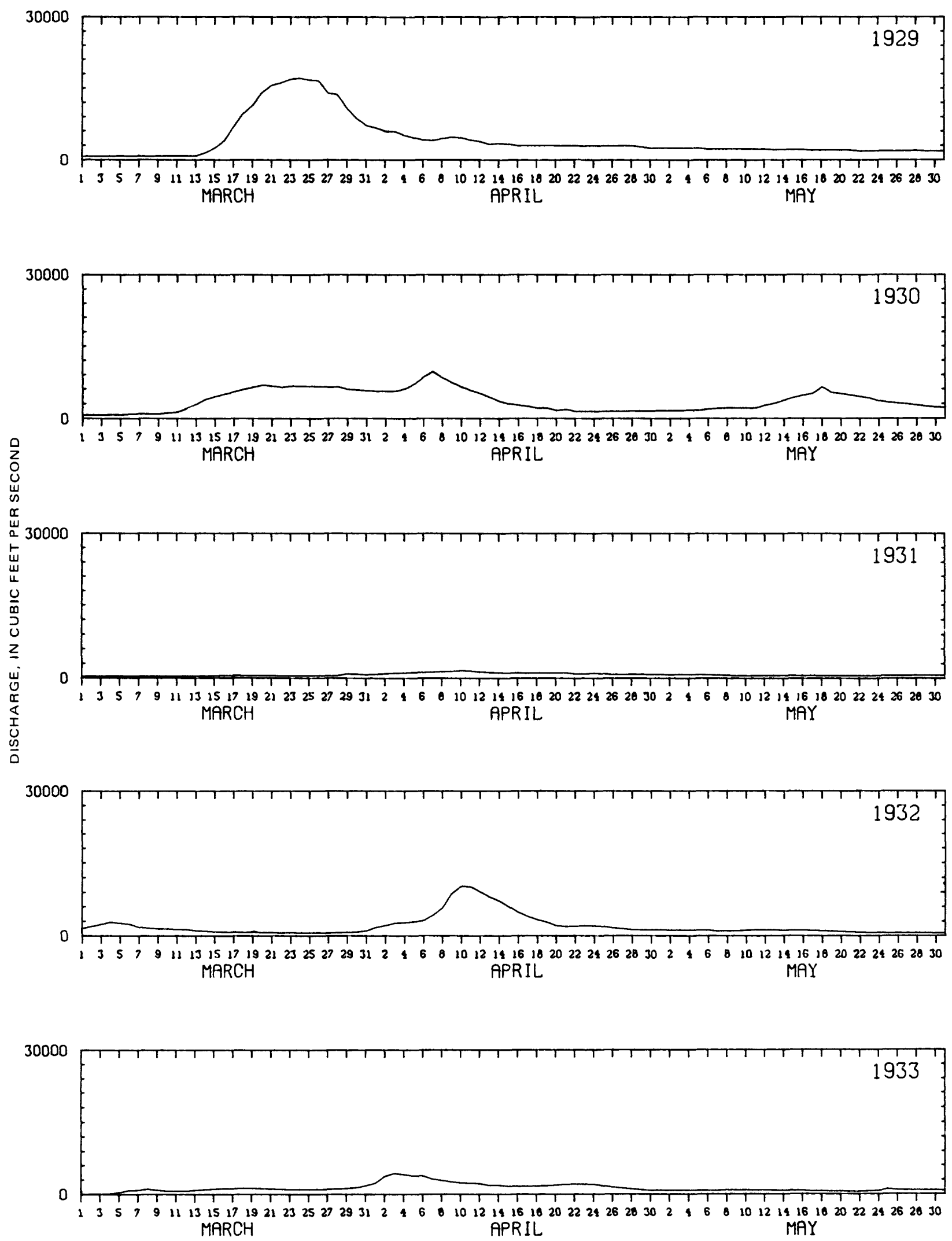

Attachment C 77 
Attachment C2. Continued
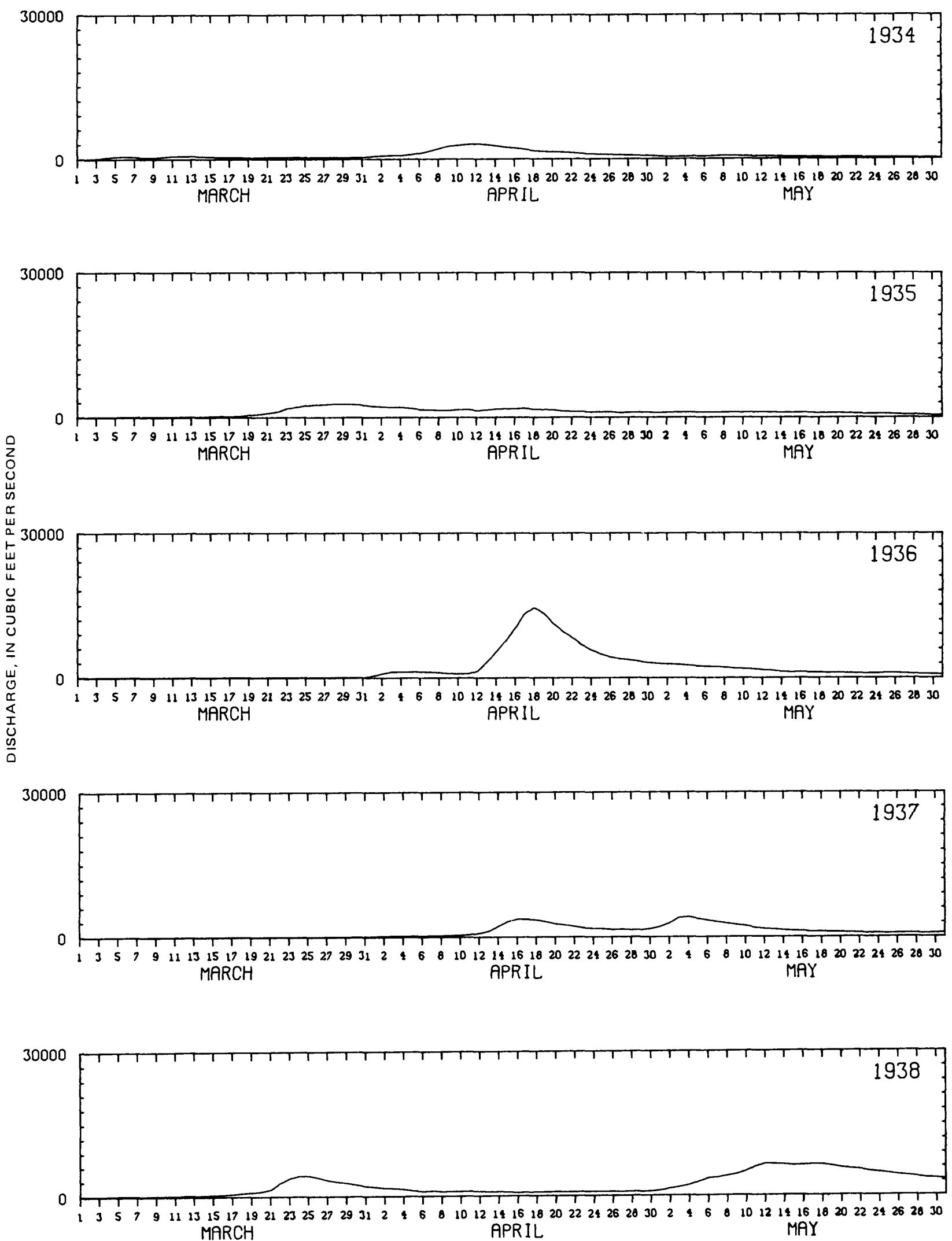
Attachment C2. Continued
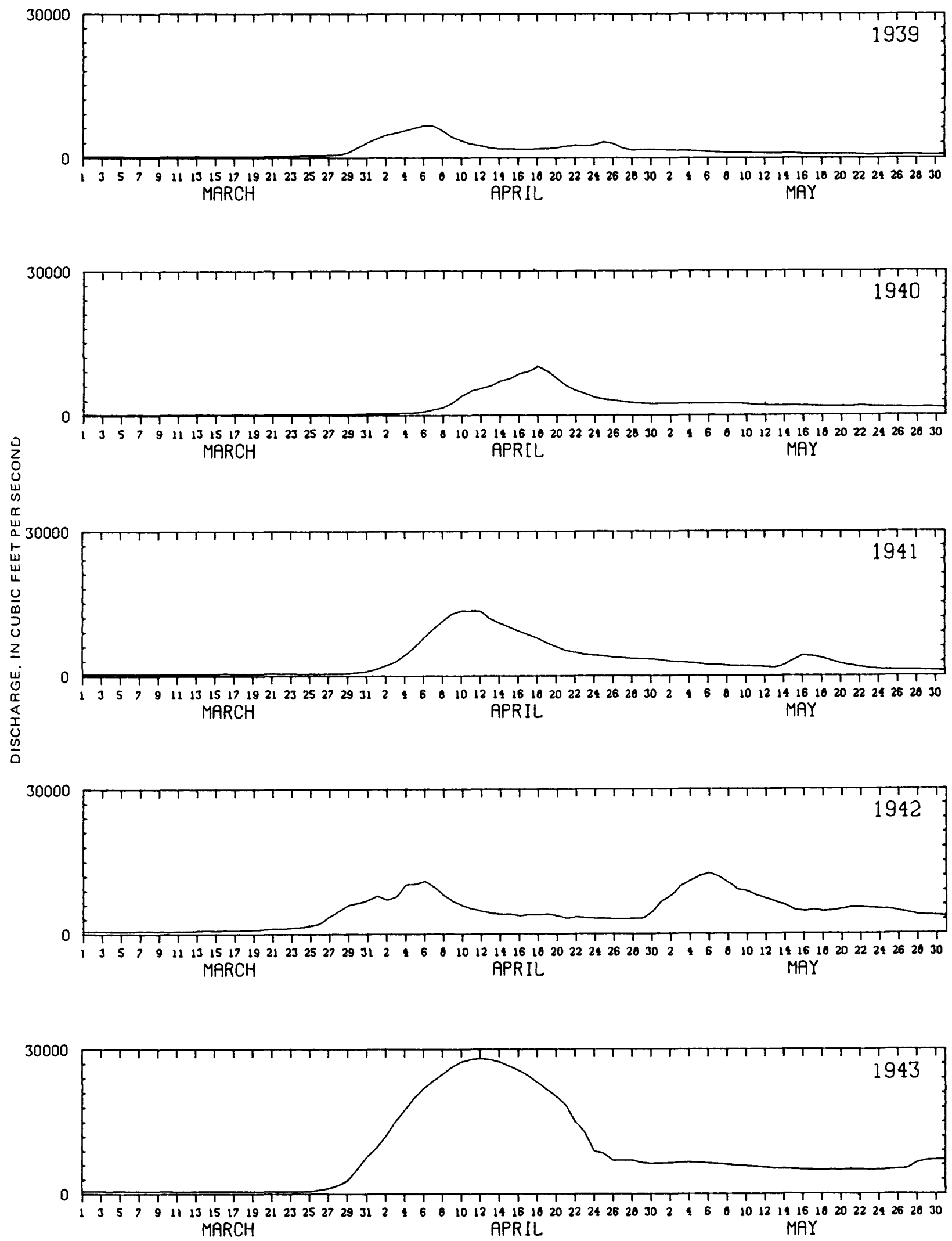

Attachment C 79 


\section{Attachment C2. Continued}
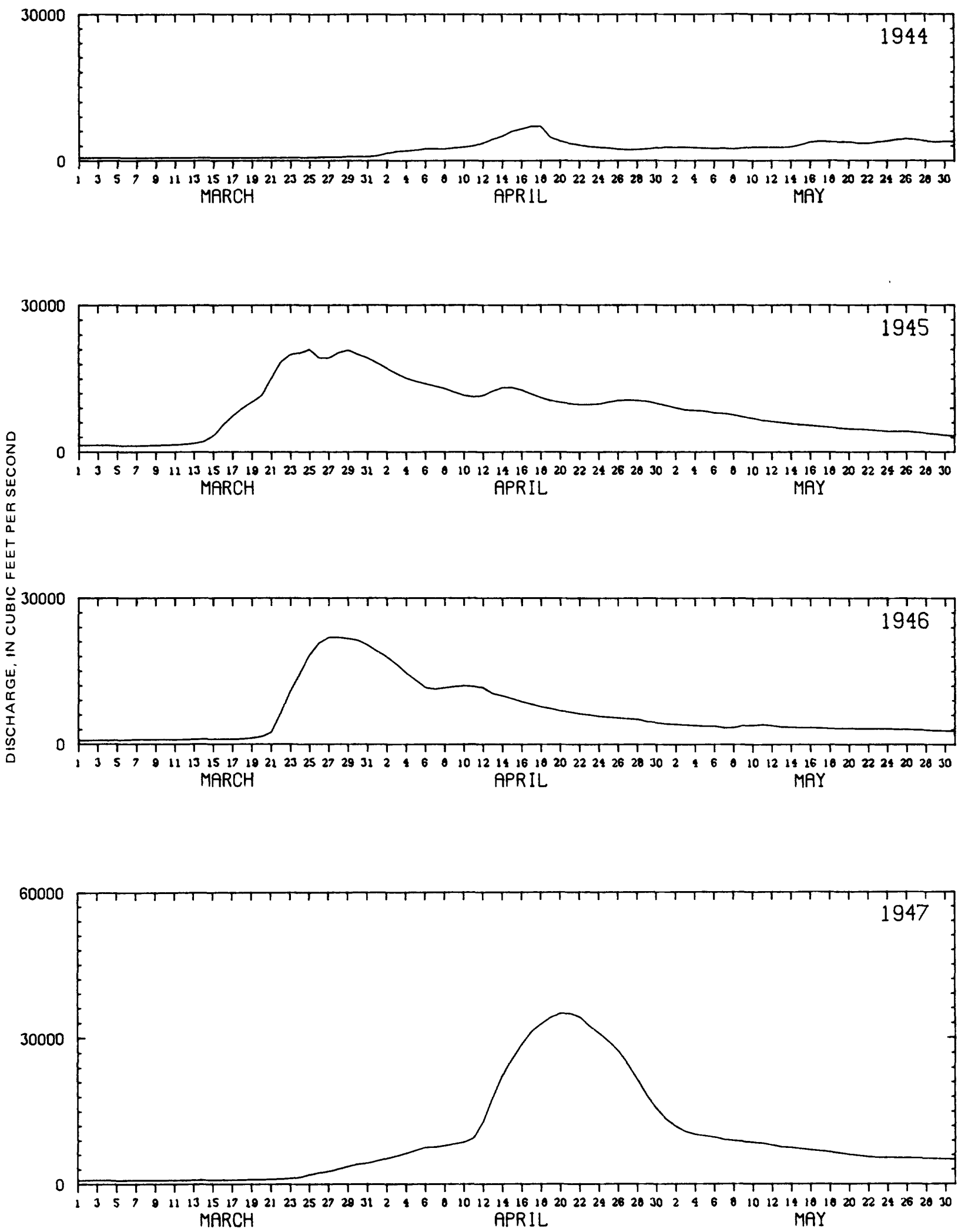
Attachment C2. Continued
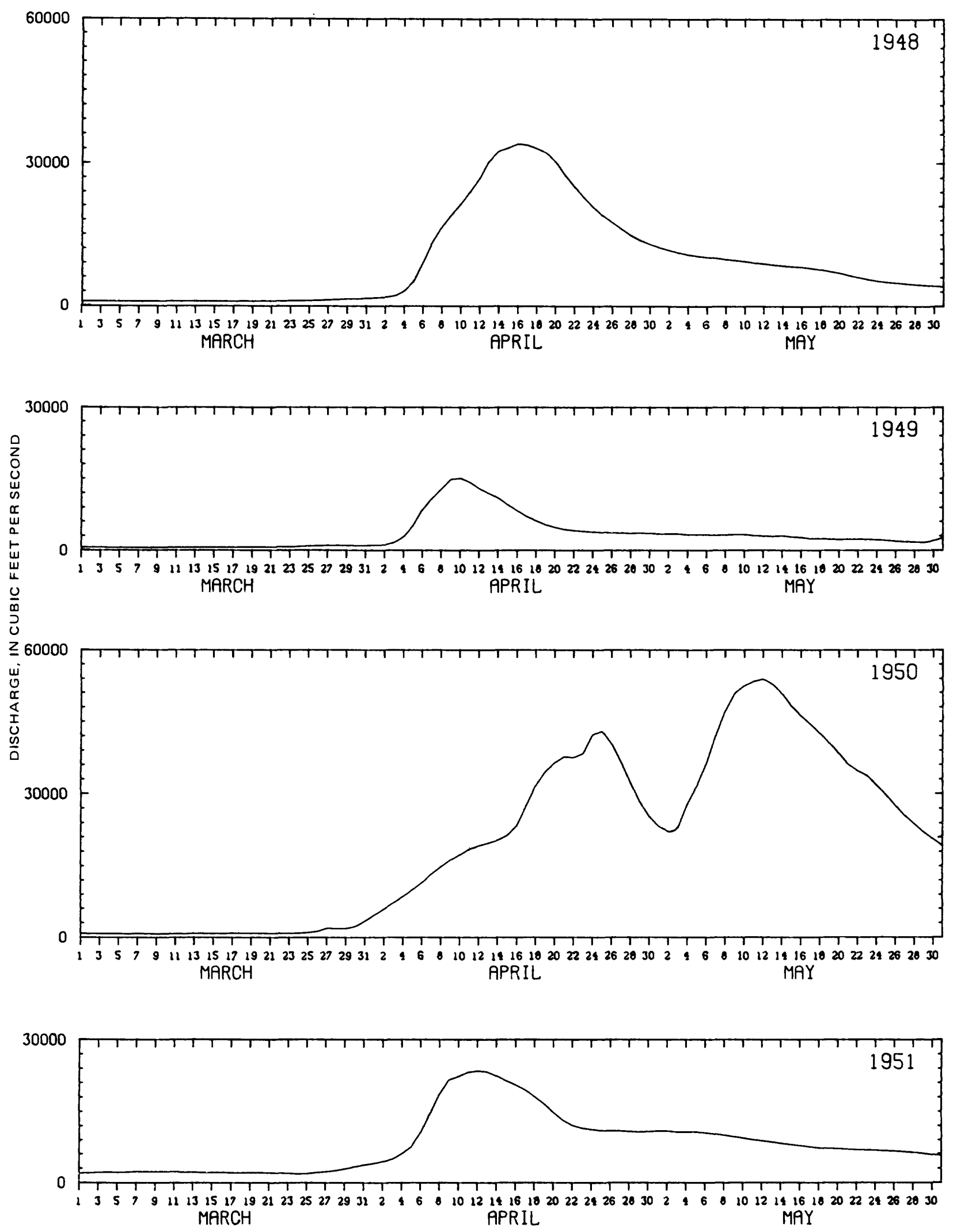

Attachment C 
Attachment C2. Continued
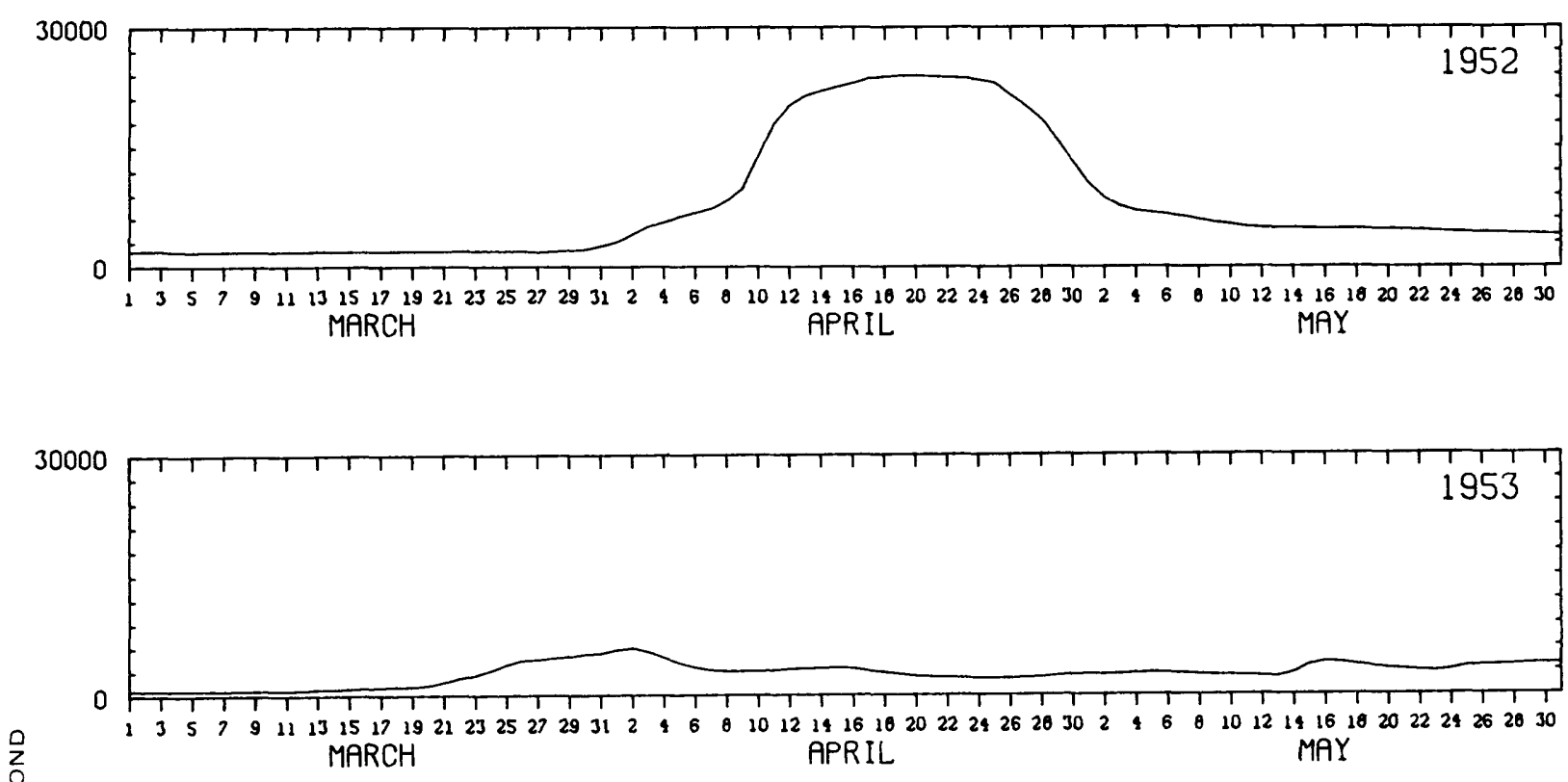

0

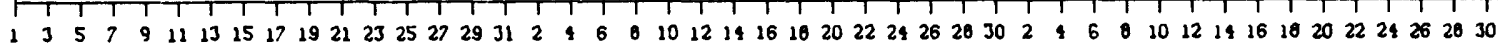
MARCH APRIL

MAY

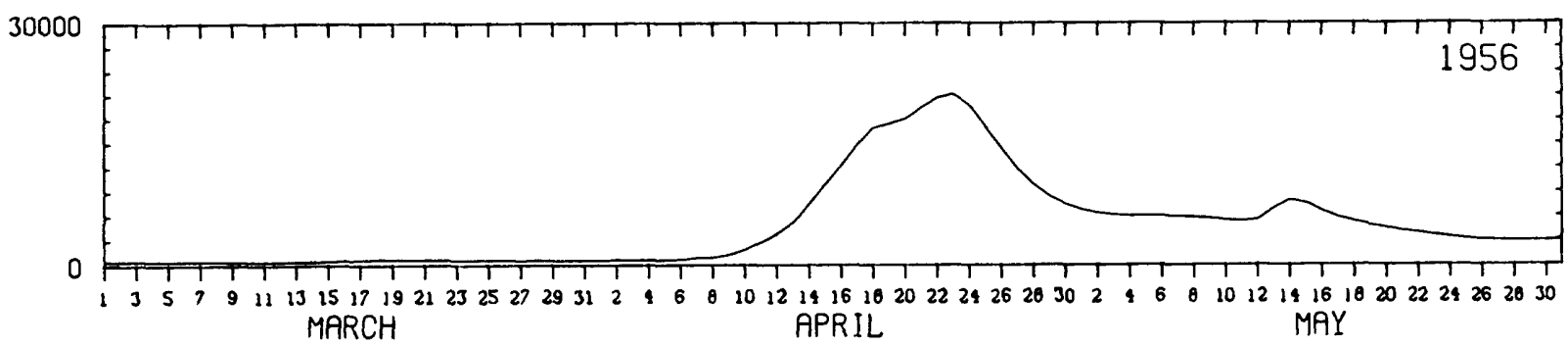


Attachment C2. Continued
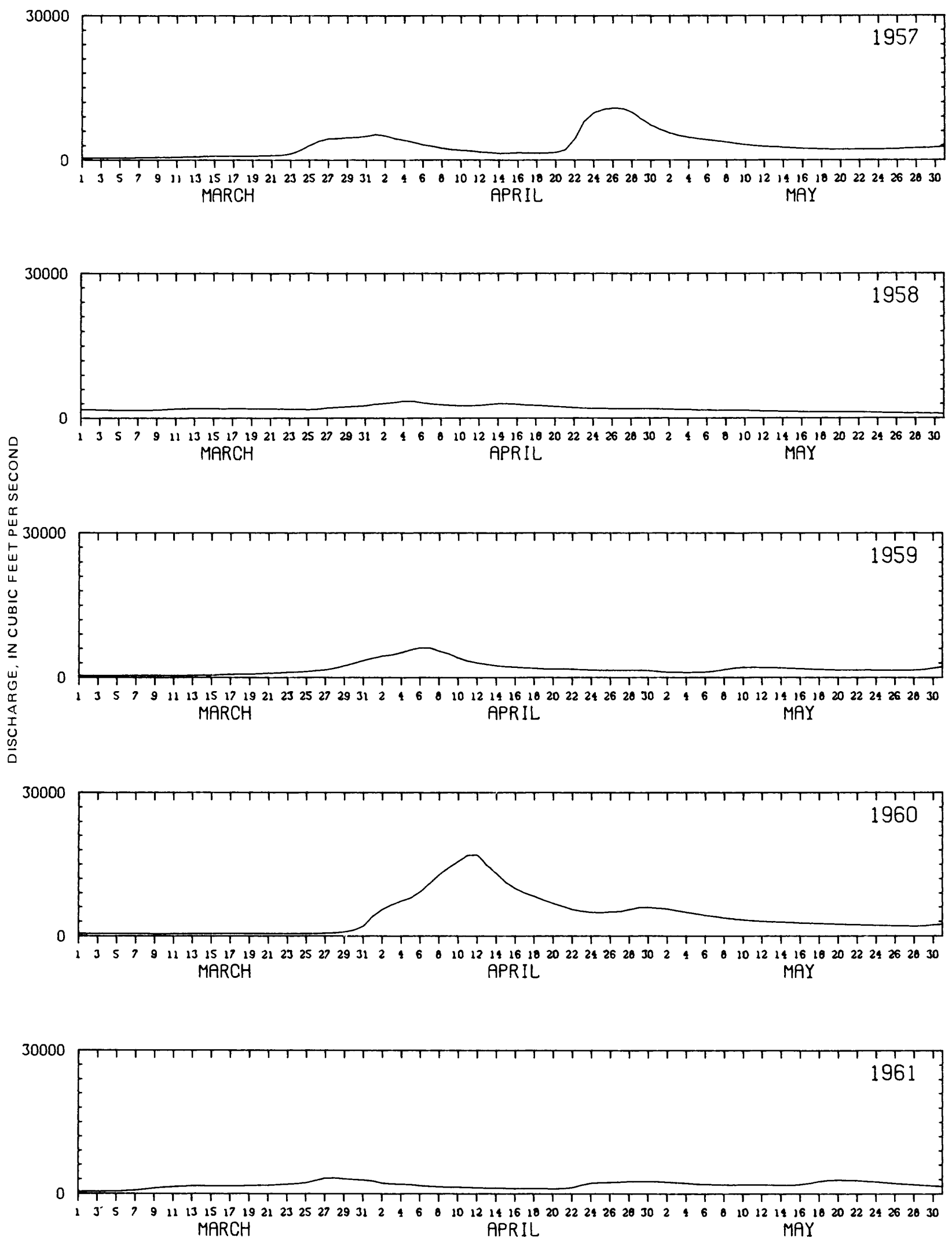

Attachment C 83 
Attachment C2. Continued
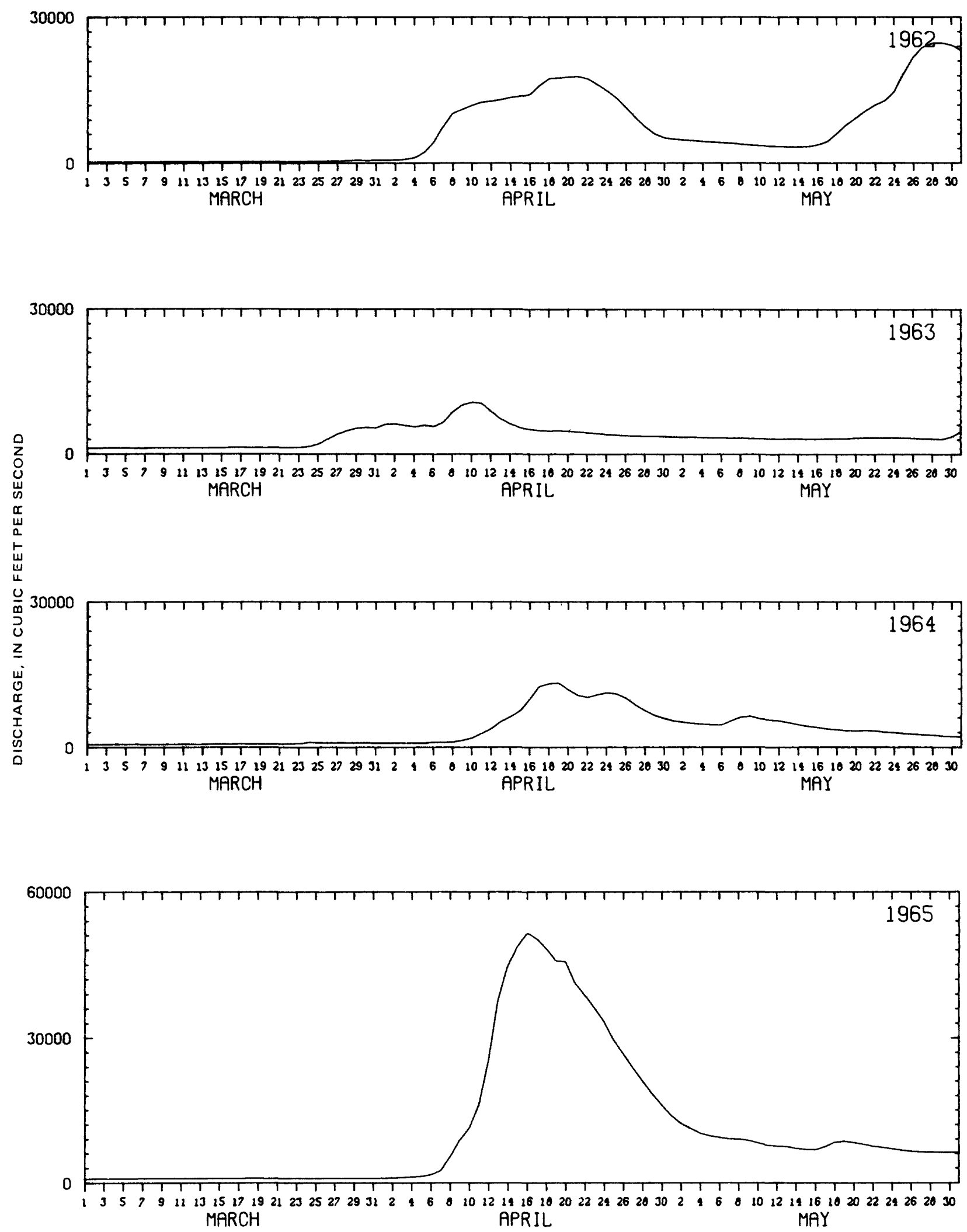
Attachment C2. Continued
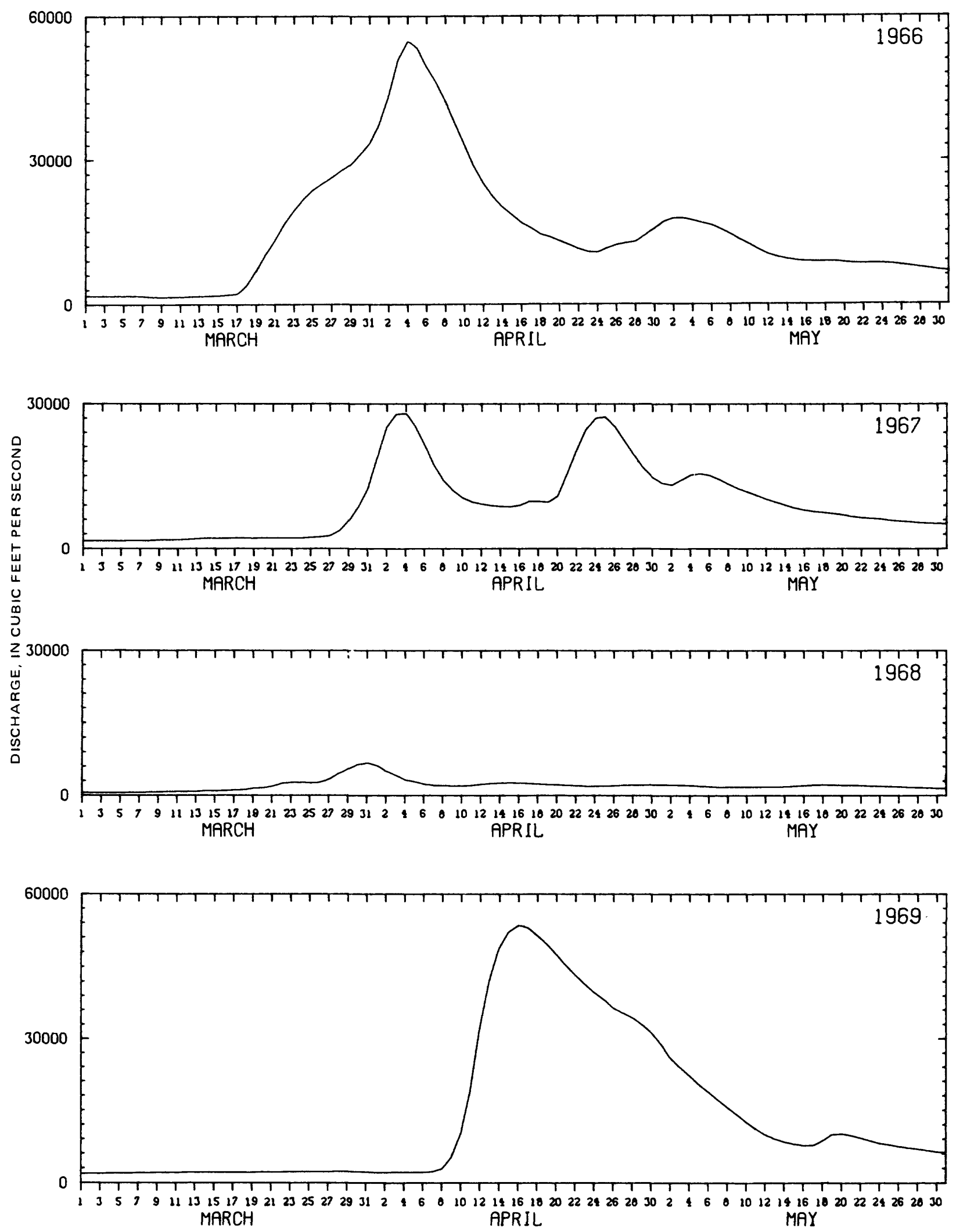

Attachment C 85 

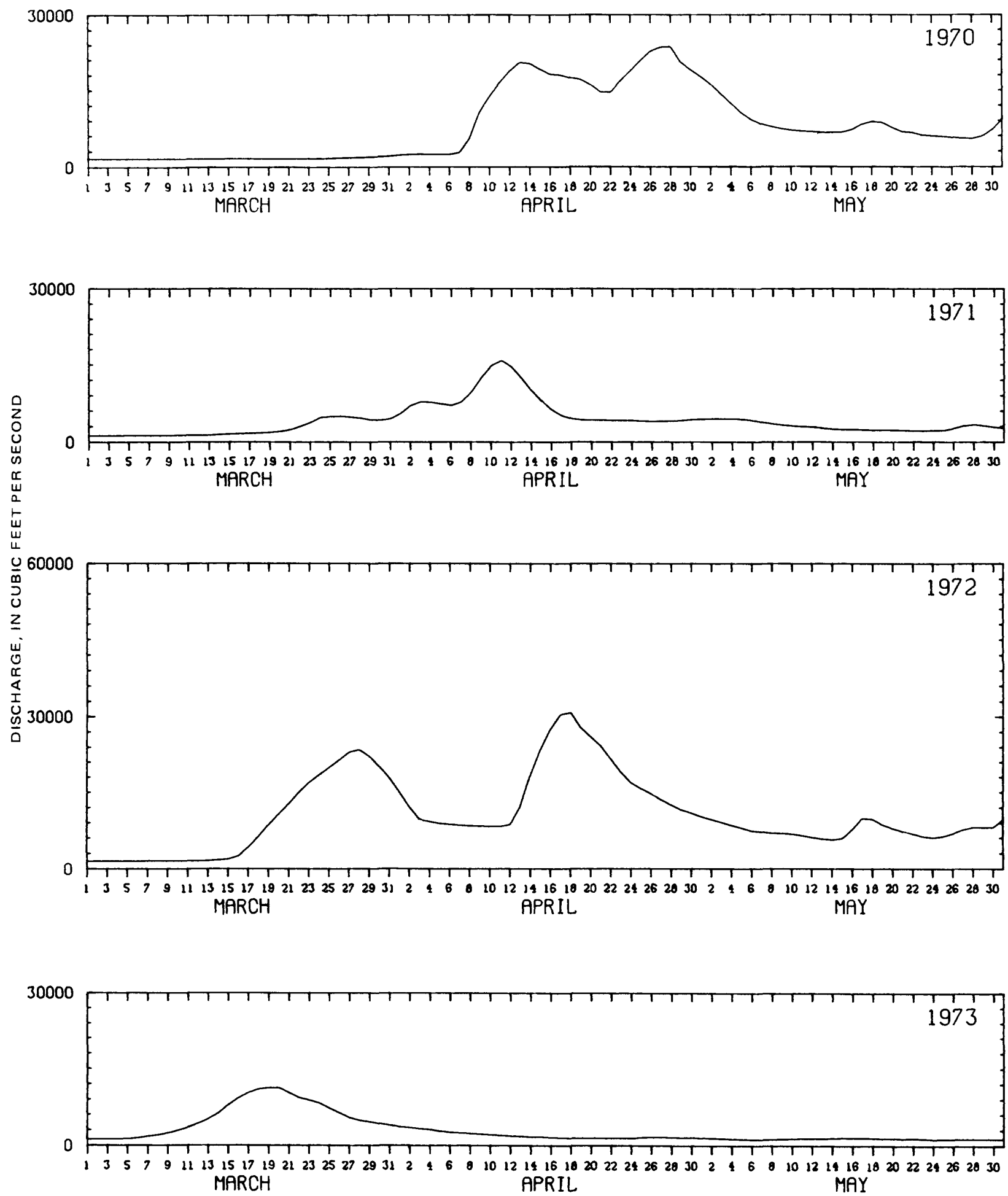
Attachment C2. Continued
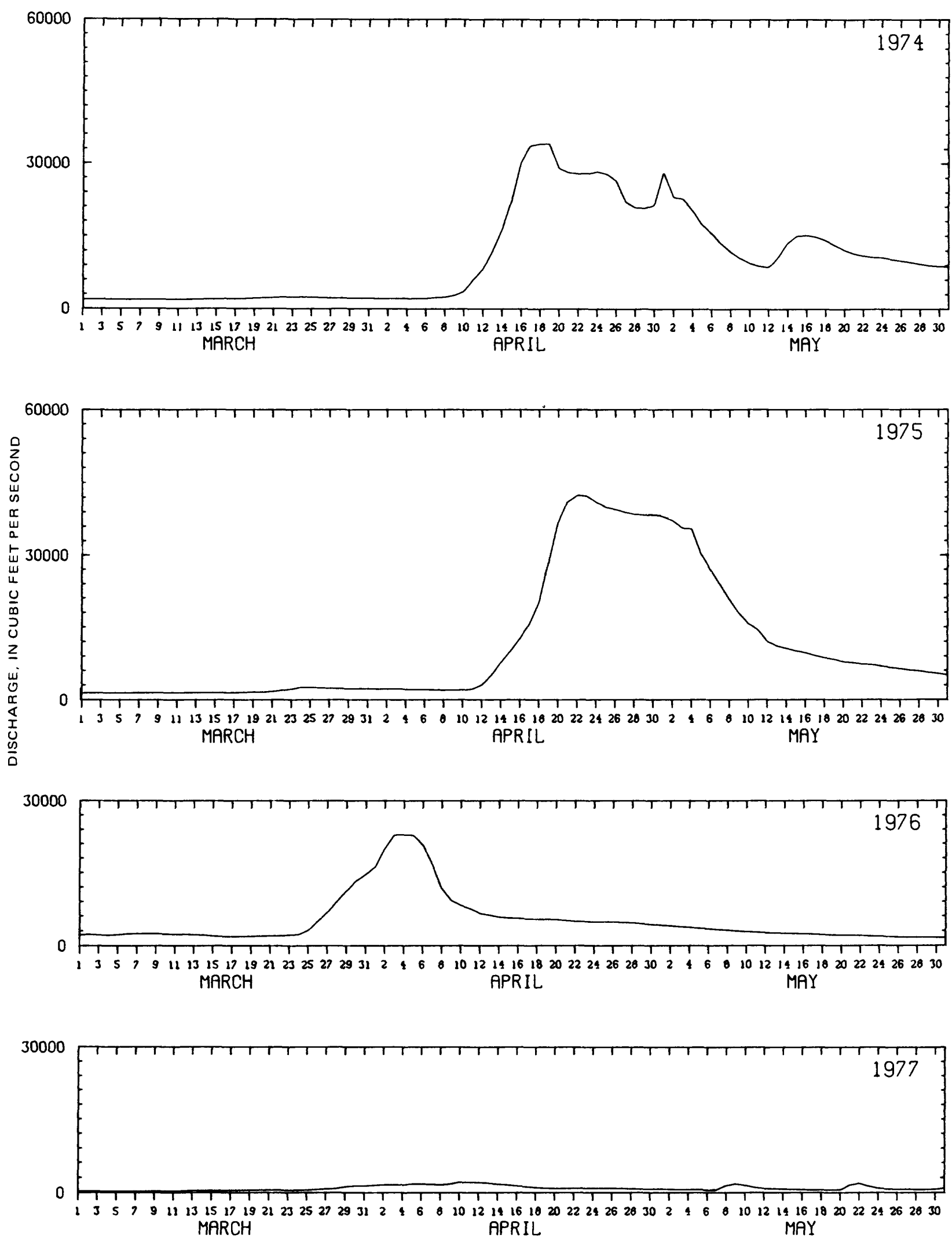

Attachment C 87 
Attachment C2. Continued
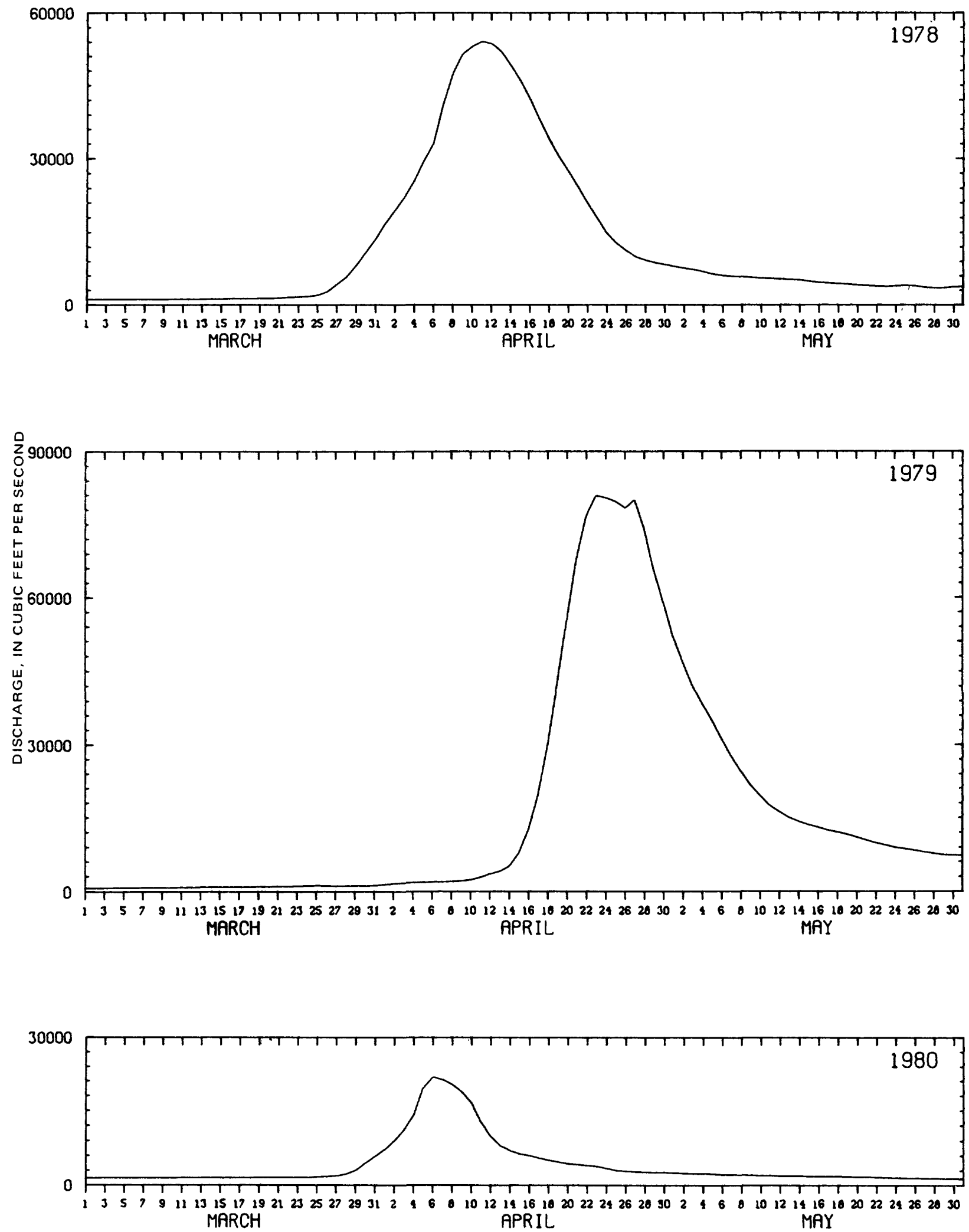


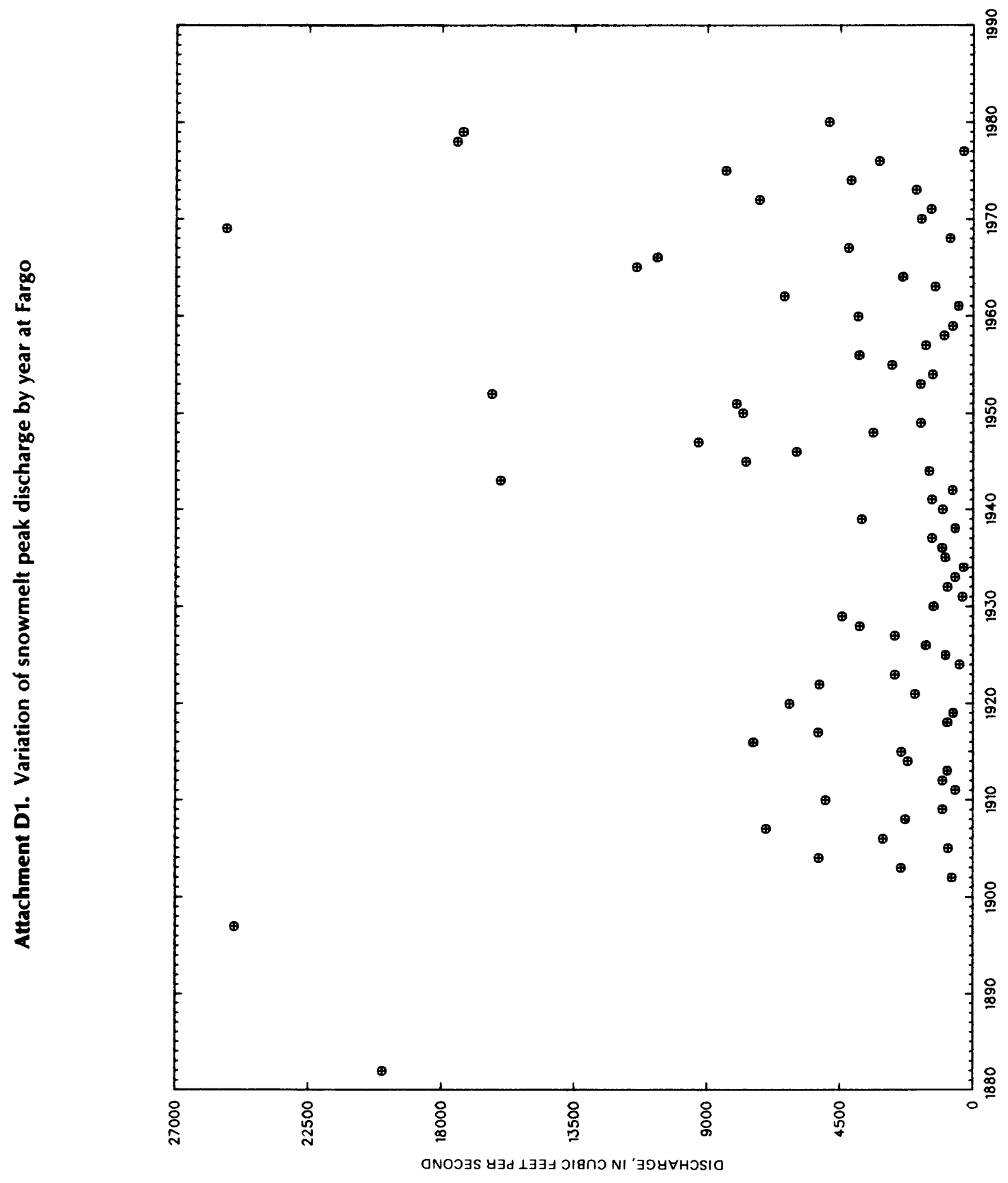

Attachment D 89 


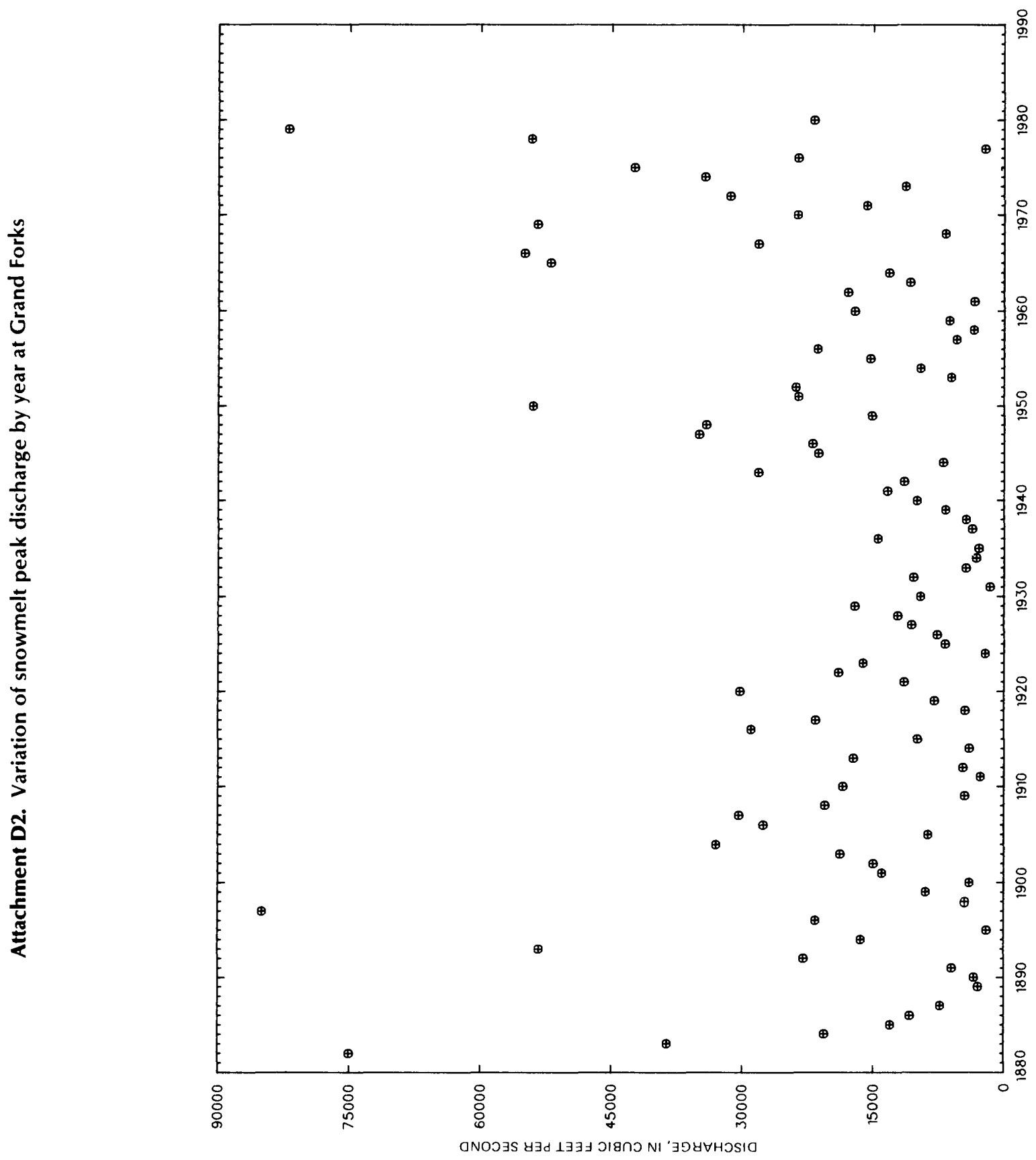

90 Flood Response, Red River, N. Dak. Dak - Minn. 


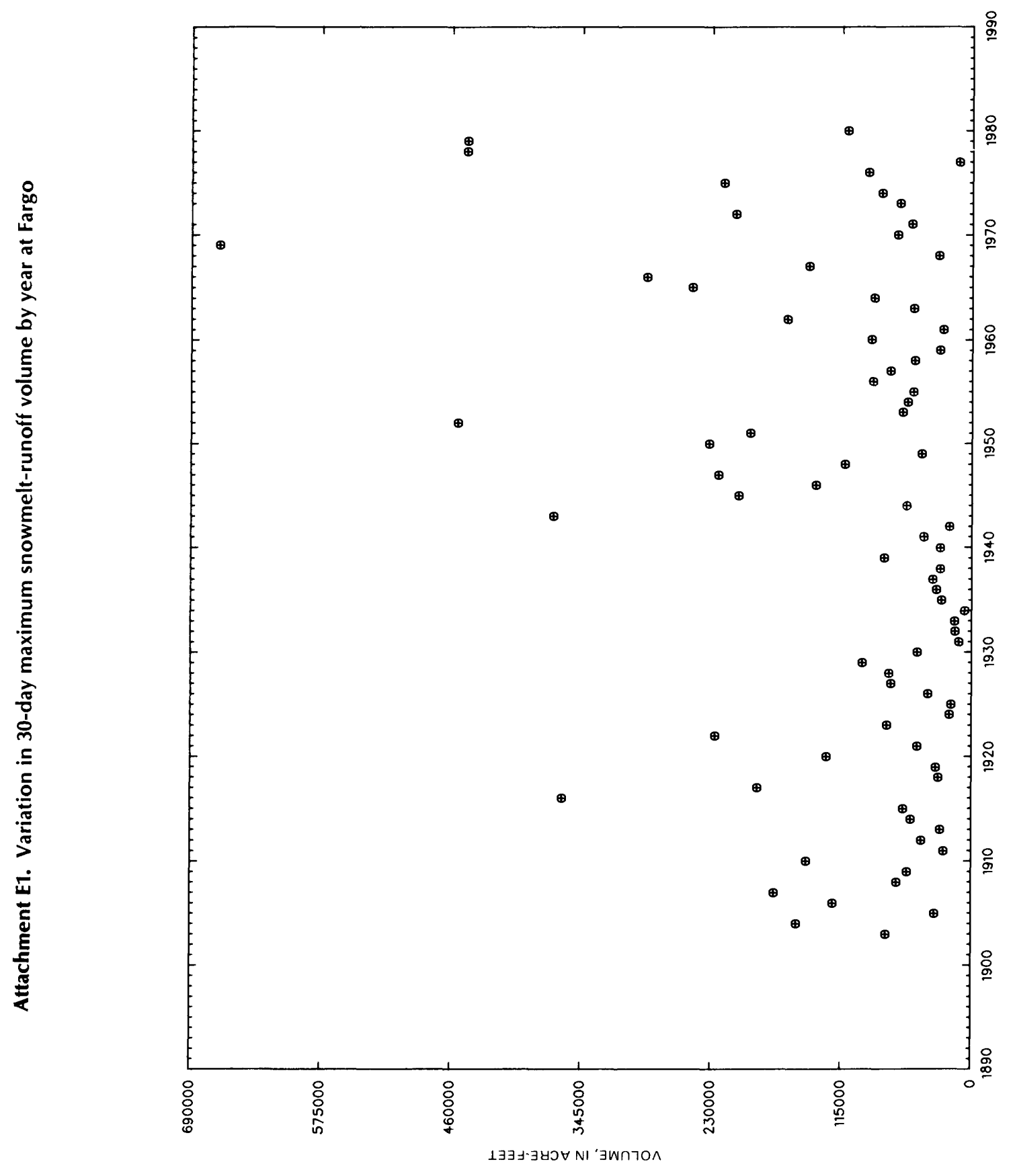




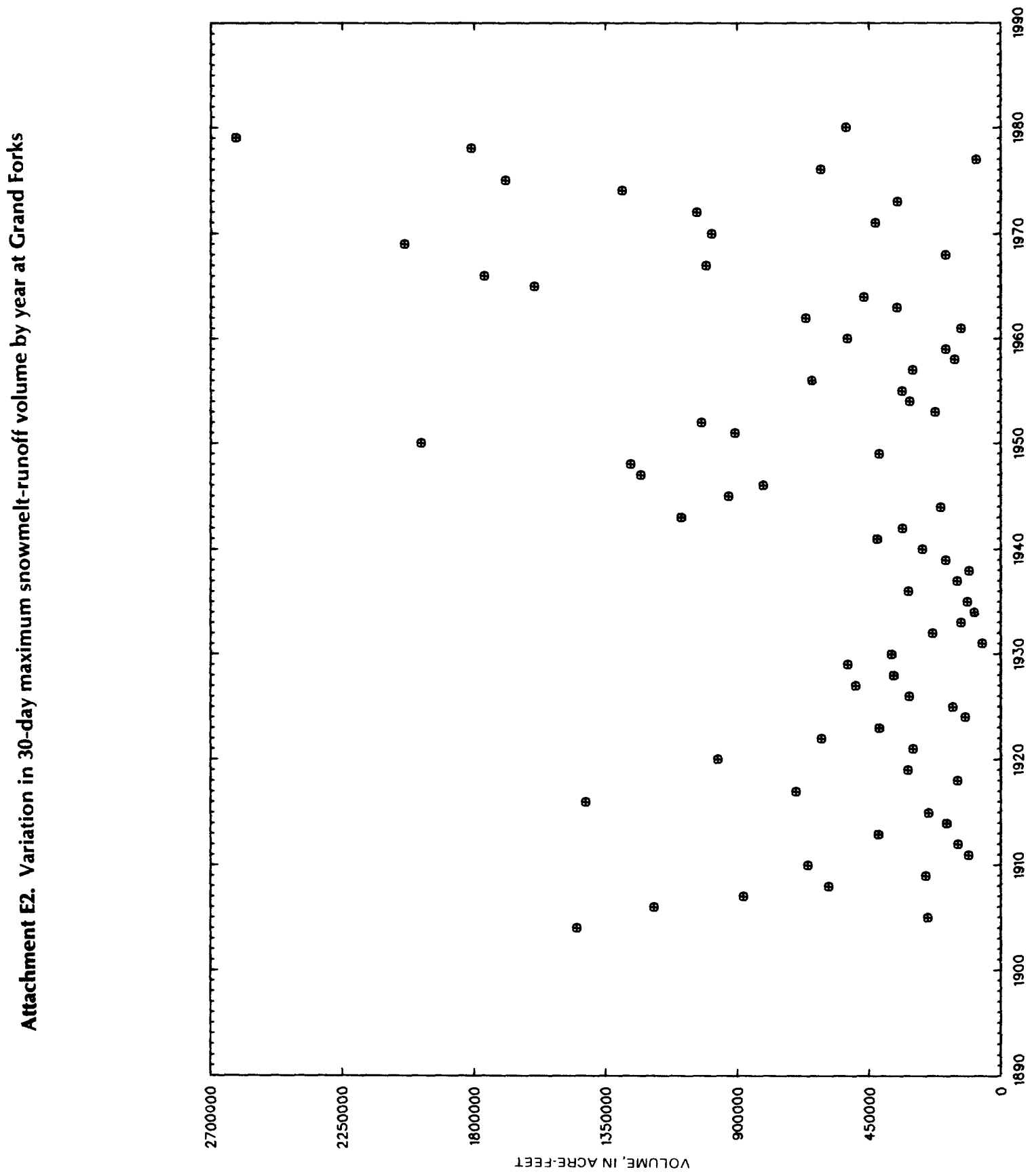

92 Flood Response, Red River, N. Dak. Dak-Minn. 


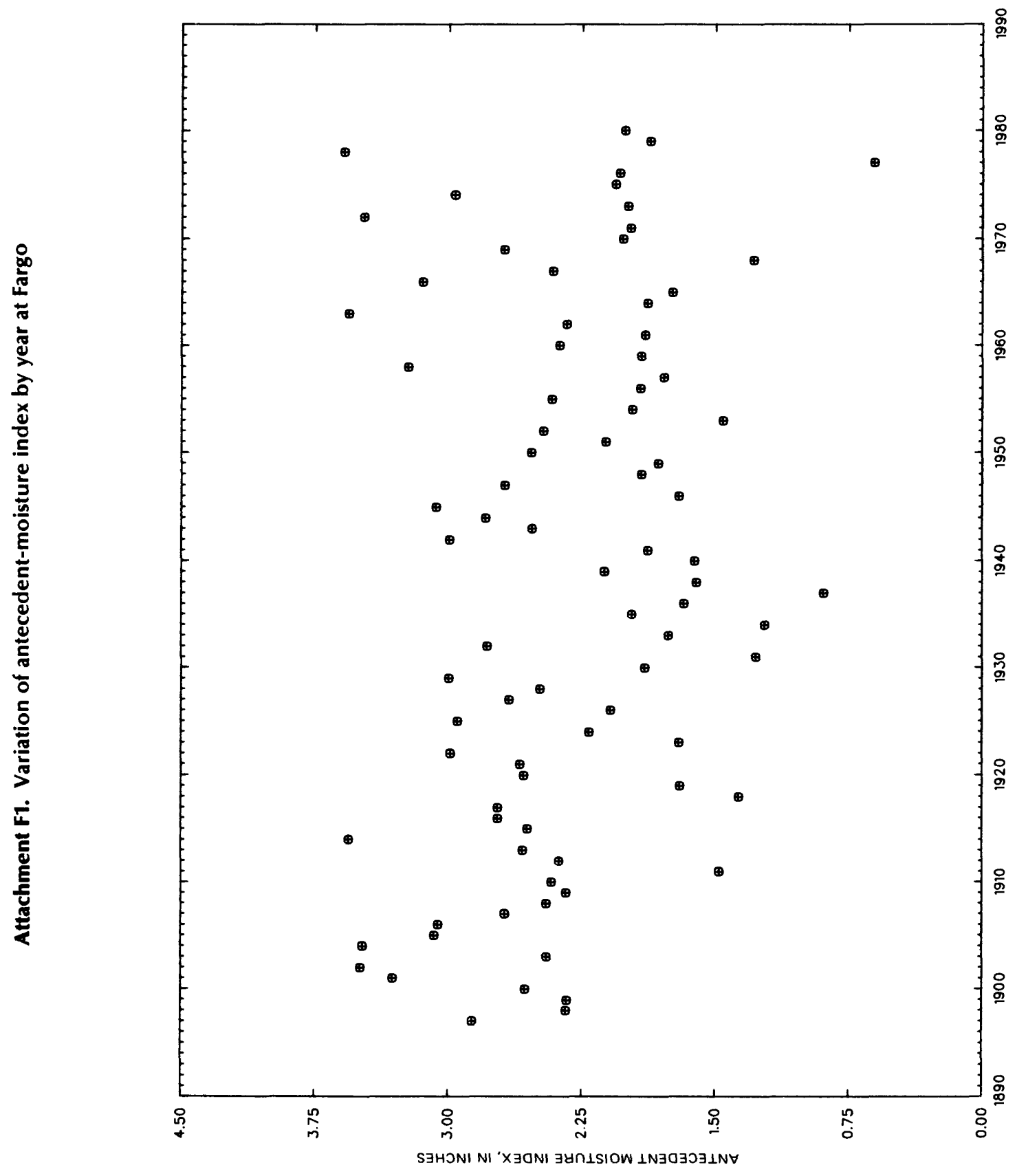




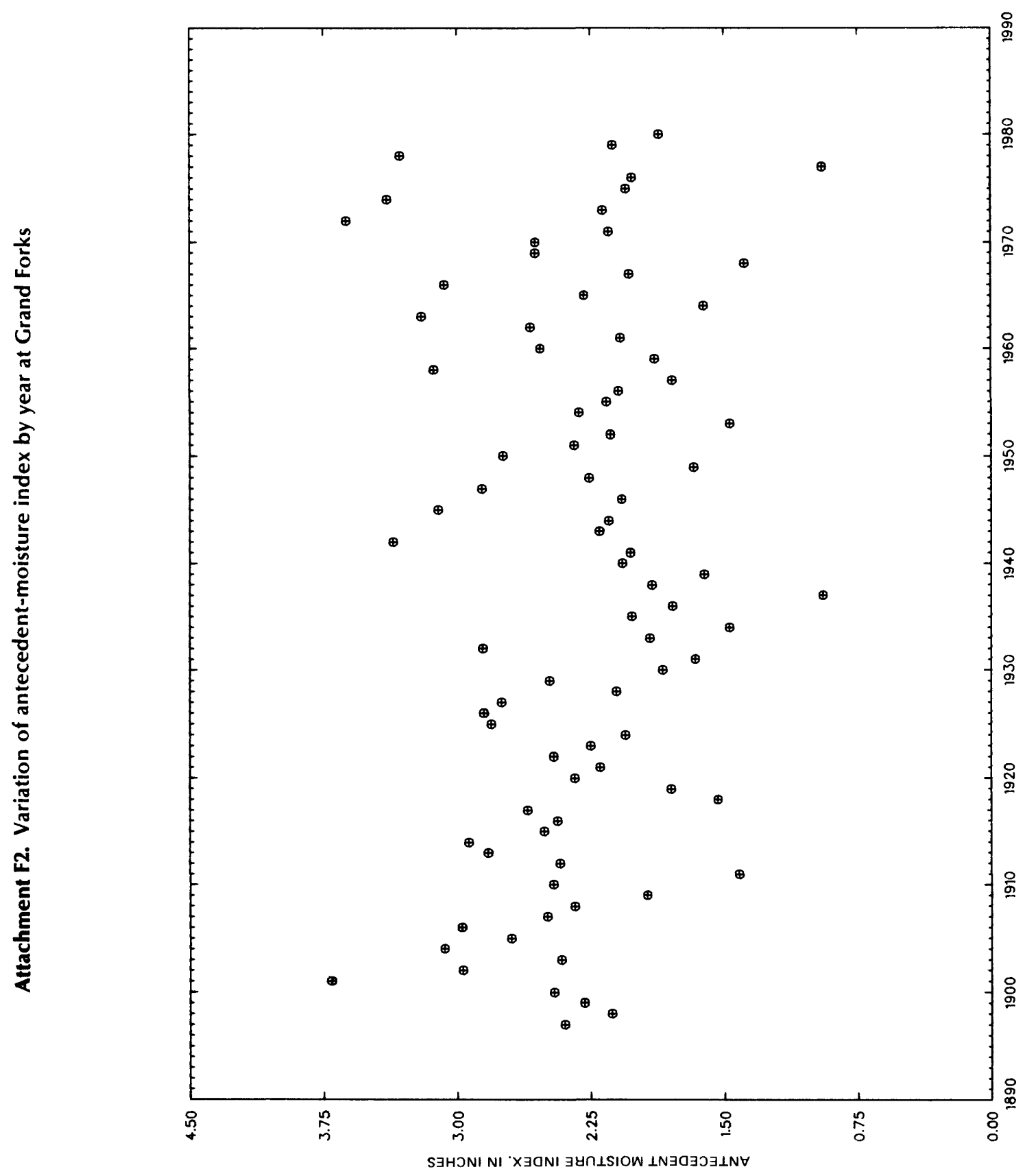

94 Flood Response, Red River, N. Dak. Dak-Minn. 


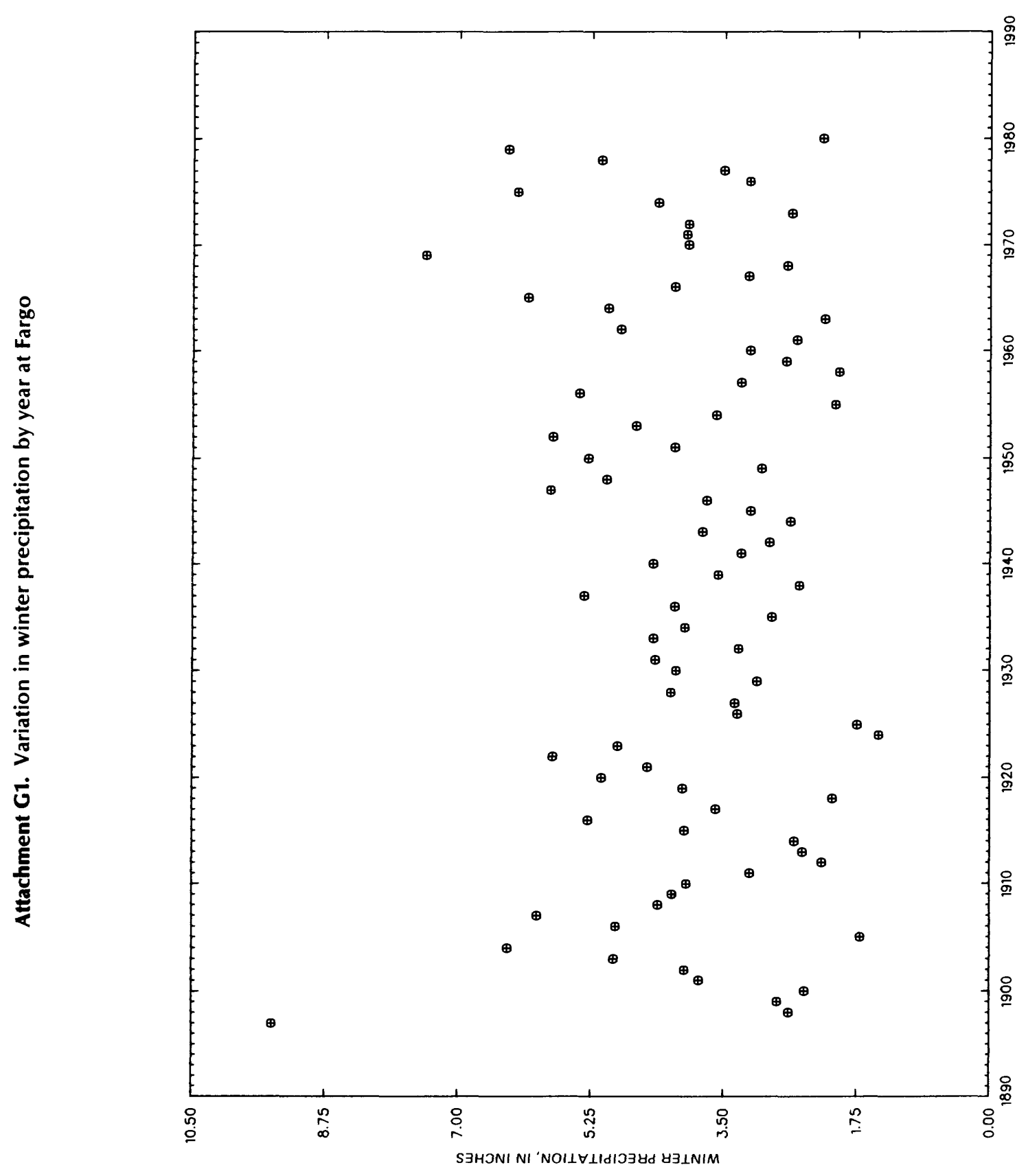




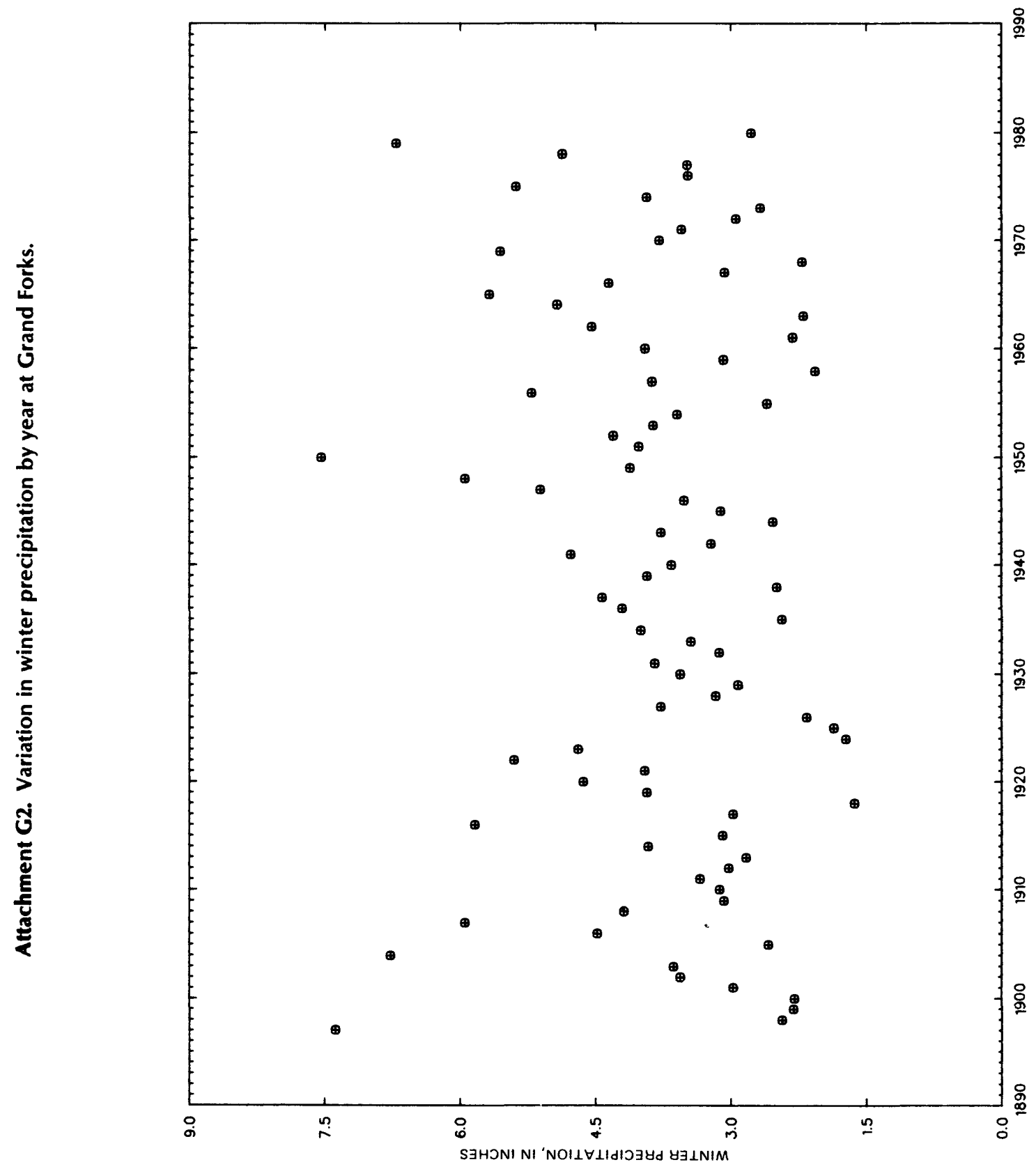




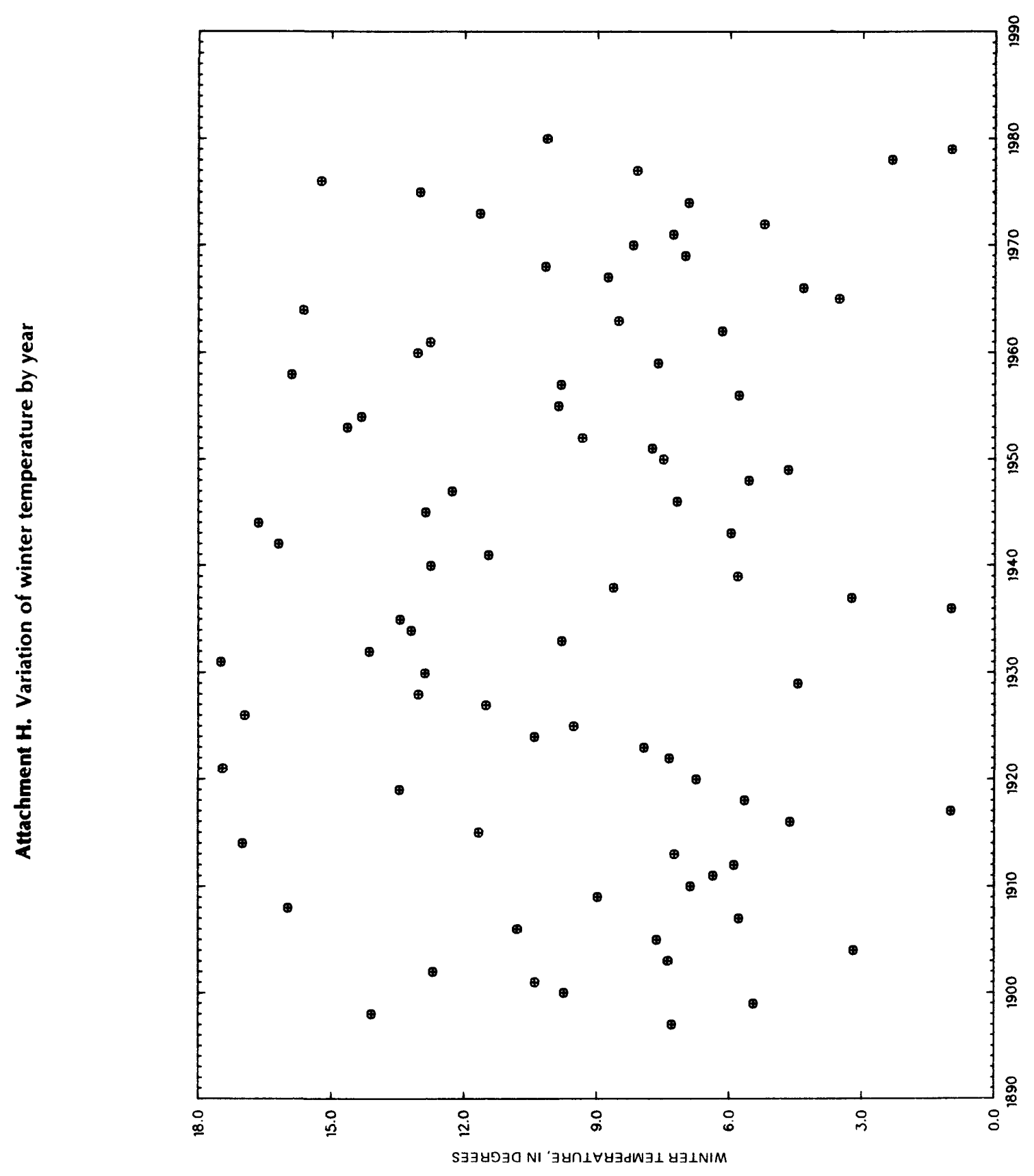

Attachment H 97 


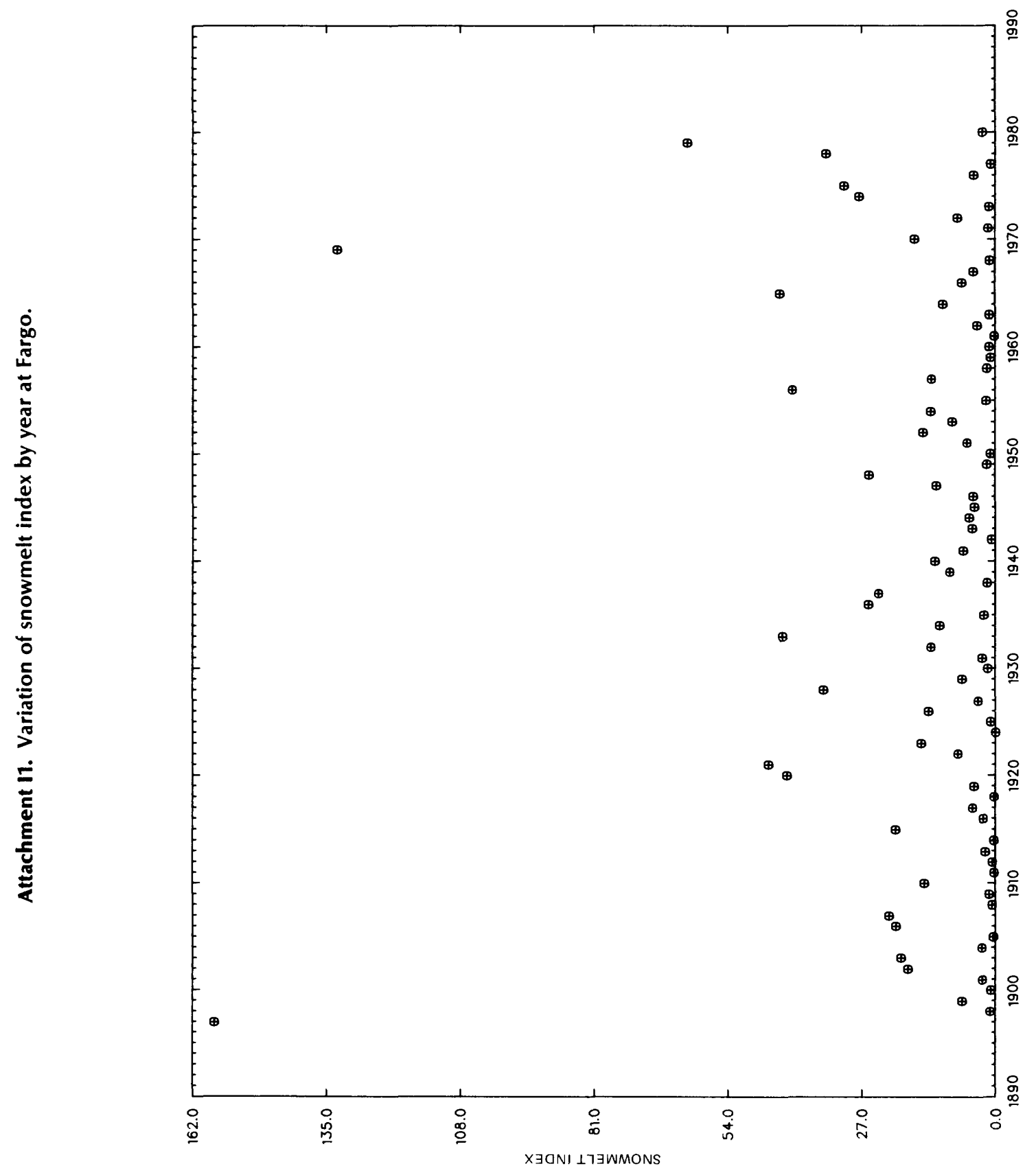

98 Flood Response, Red River, N. Dak. Dak-Minn. 


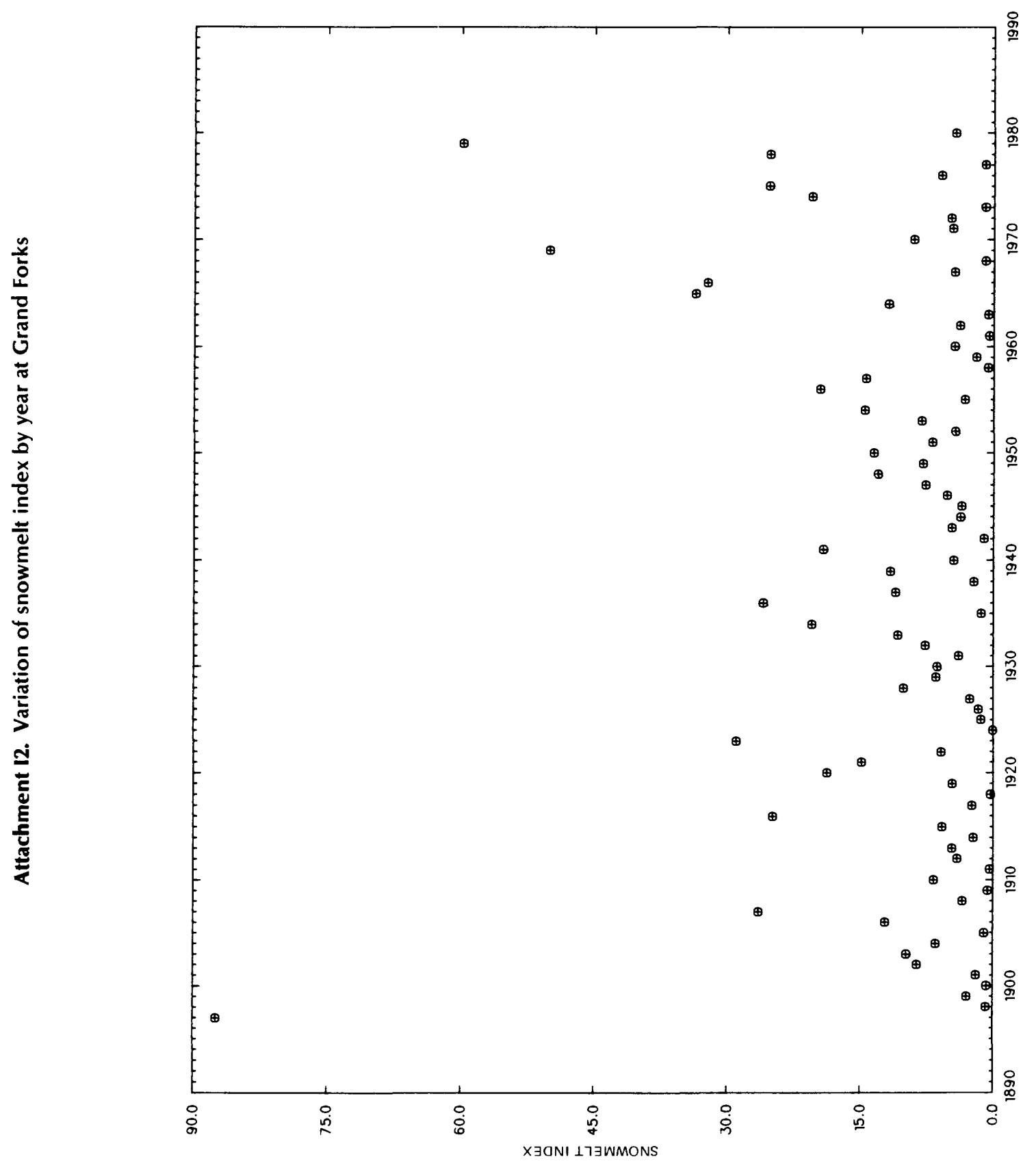




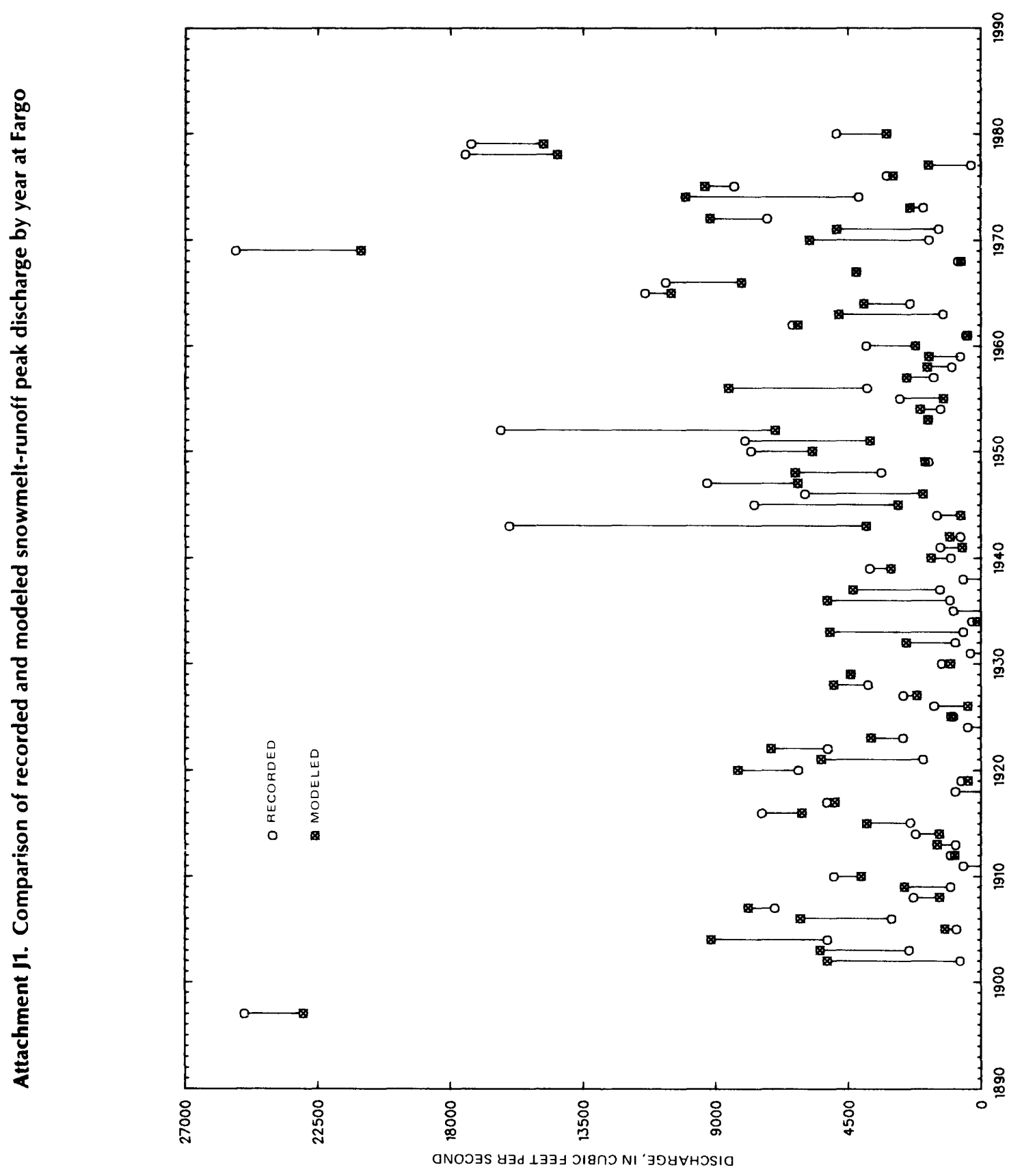




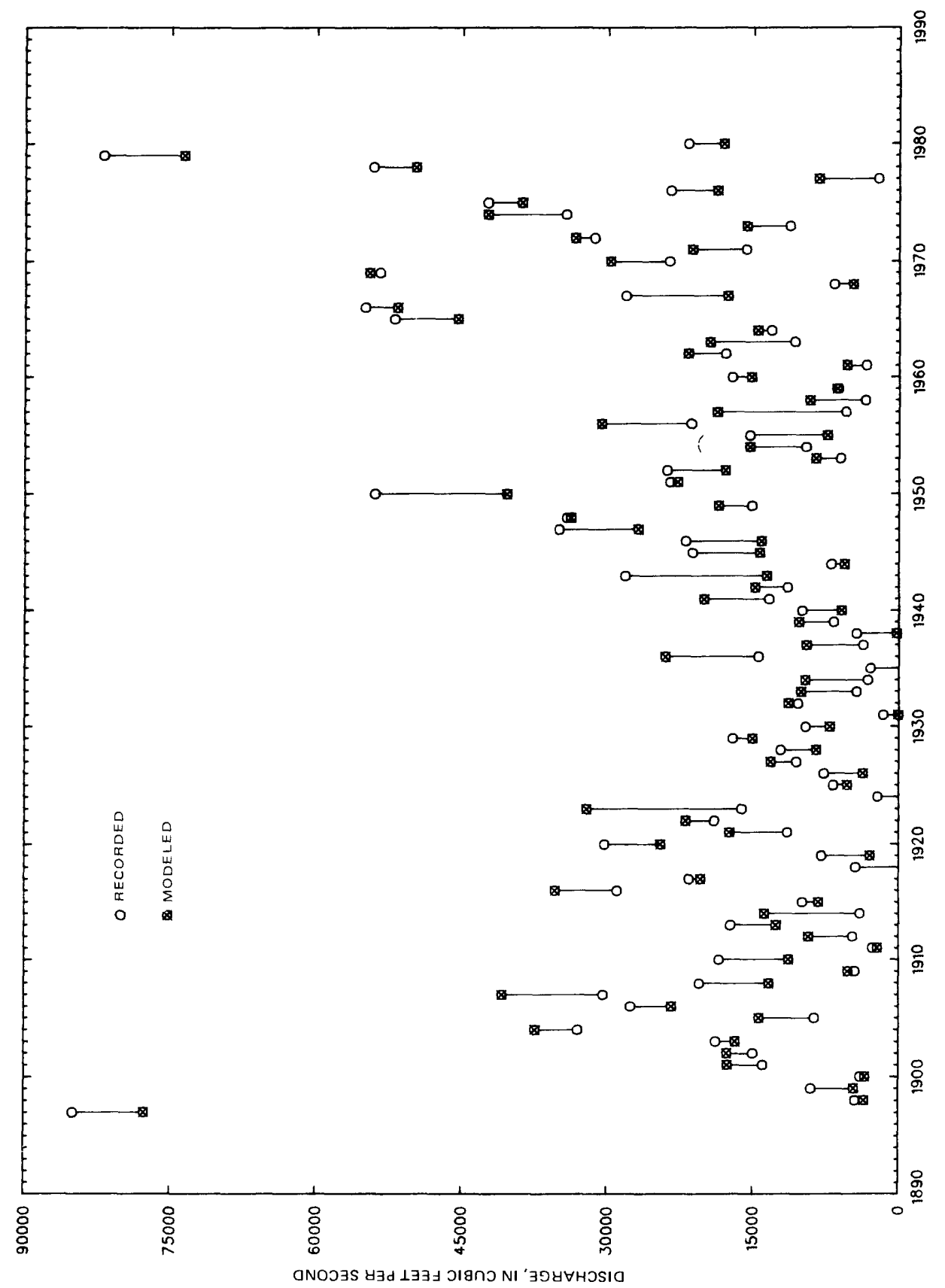




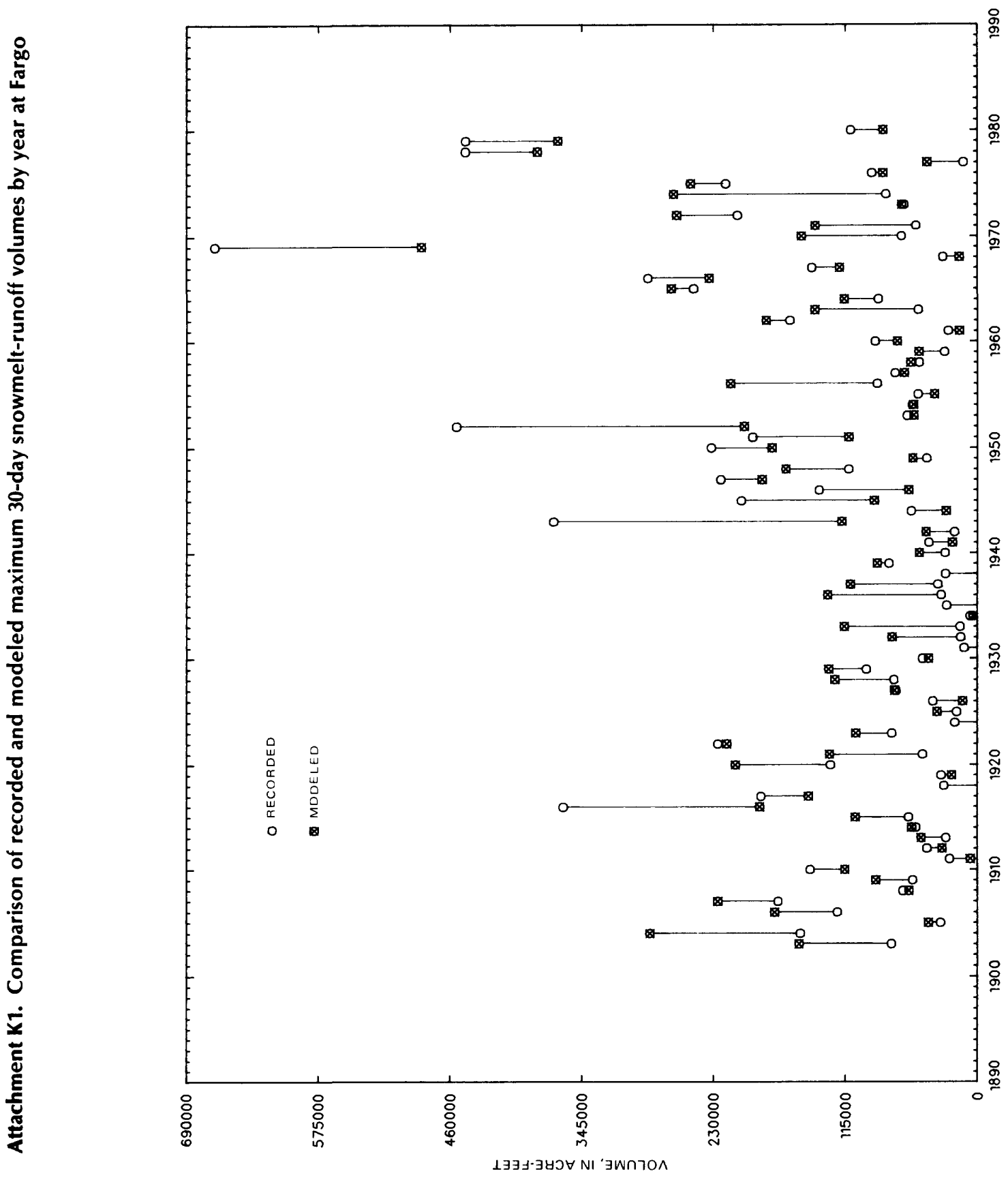




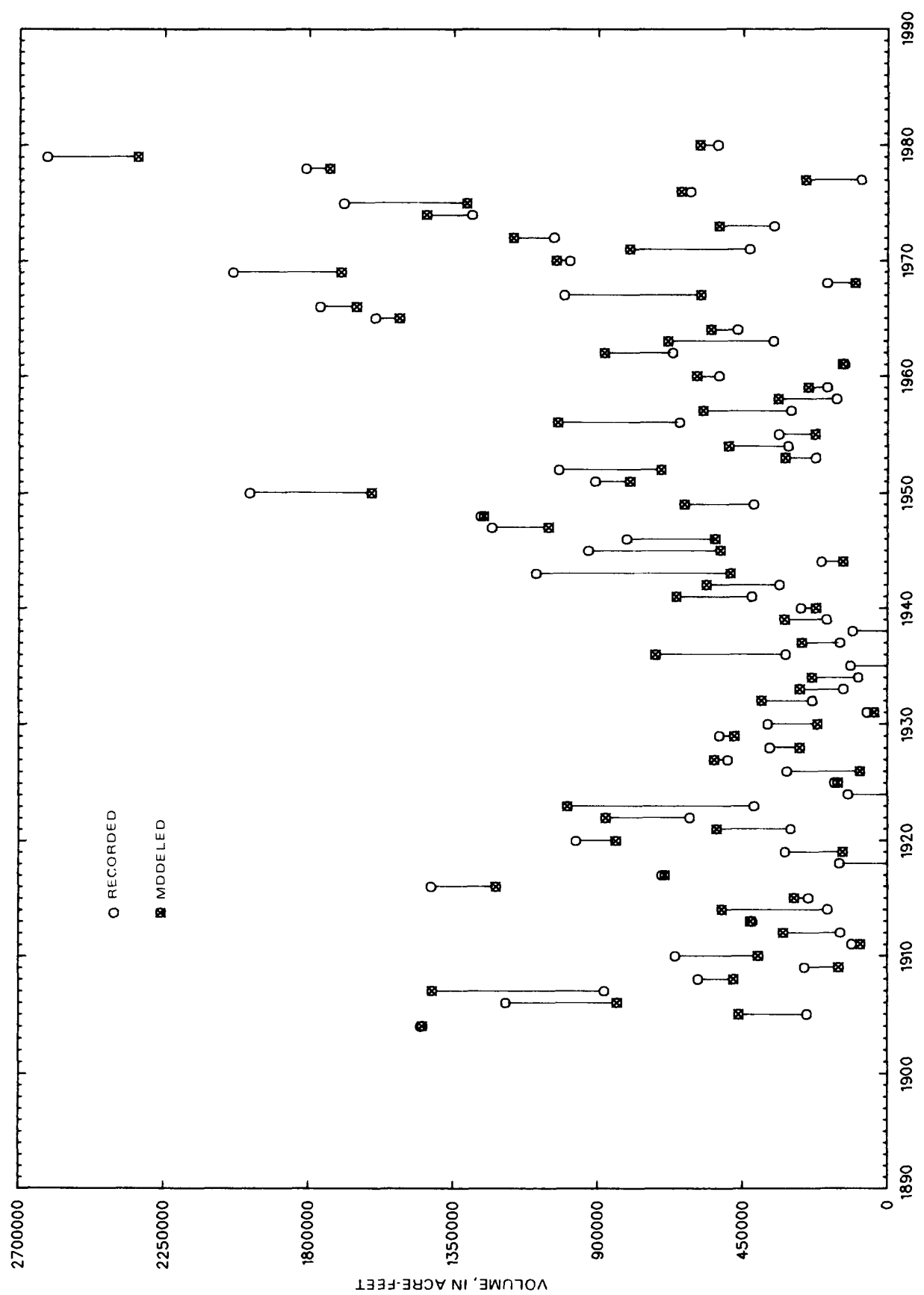

